\title{
Reintegração social: discursos e práticas na prisão- um estudo comparado
}

Tese de Doutorado apresentada à Banca Examinadora da Faculdade de Direito da Universidade de São Paulo como exigência parcial para obtenção do título de doutora em Direito Penal, sob a orientação do Prof. Livre Docente Alvino Augusto de Sá.

Faculdade de Direito da Universidade de São Paulo São Paulo - 2012 
Reintegração social: discursos e práticas na prisãoum estudo comparado

Ana Gabriela Mendes Braga

Exame de Defesa da Tese

DATA

BANCA EXAMINADORA

$1^{\circ}$ Examinador

Orientador Prof. Livre Docente Alvino Augusto de Sá

$2^{\circ}$ Examinador(a)

$3^{\circ}$ Examinador(a)

$4^{\circ}$ Examinador(a)

$5^{\circ}$ Examinador(a) 
Para

Bill, Rita e Betty que enchem minha vida de amor 


\section{AGRADECIMENTOS}

Primeiramente, agradeço a CAPES e Fundación Carolina, pelo auxílio concedido, que possibilitou a realização do estágio doutoral na Universitat de Barcelona e a ampliação do universo desta pesquisa.

Agradeço ao meu orientador, Alvino Augusto de Sá, que além ter me guiado na construção dessa pesquisa, teve um papel essencial na minha entrada no mundo acadêmico e na minha inserção nos espaços prisionais.

A Sérgio Salomão Shecaira, por ter despertado meu interesse pela Criminologia ainda na Graduação, e seguir arriscando novos olhares sobre as Ciências Penais. Suas colocações na banca de qualificação contribuíram para que eu apurasse minha análise da teoria criminológica e da própria realidade prisional.

À Ana Lúcia Pastore, por me introduzir ao universo fascinante da Antropologia e me guiar nas aproximações dessa ciência com o Direito. Professora de escuta interessada e fala doce, por quem guardo um carinho imenso. Seu cuidado na leitura do texto de qualificação e suas precisas observações foram essenciais para minha tentativa de construção de um trabalho interdisciplinar.

À todos os professores da Universitat de Barcelona. Primeiramente, agradeço a Manuel Delgado Ruiz, orientador do estágio doutoral, por ter me acolhido com tanto carinho e entusiasmo, me encorajando a percorrer caminhos até então desconhecidos. E, em especial aos professores Iñaki Rivera Beiras e Júlio Zino Torraza, que muito contribuíram para este trabalho e para minha entrada no meio acadêmico catalão.

À todos meus colegas de Pós-Graduação, cuja presença nesse período trouxe reconforto ao exercício desse trabalho, muitas vezes tão solitário, que é a pesquisa. Agradeço em especial Maria Emília Bretan, Bruno Shimizu, Rafael Godoi, Adalton Marques, Bruna Angotti e Gabriela Gramkow; aos pesquisadores do Núcleo de Antropologia do Direito da USP (NADIR); assim como os membros do coletivo Oficina Social Antropología e Prision, nas figuras de Dario Malventi, César Perez e Fran Garat Pey. 
Aos presos que participaram do Grupo de Dialógo Universidade-Cárcere-Comunidade (GDUCC), por permitirem que meu olhar da prisão fosse apurado pela realidade; mas principalmente, por me desafiarem a sustentar o discurso libertário na prática prisional, permitindo que eu encarasse meus medos e preconceitos na tentativa de um encontro verdadeiro.

Aos companheiros do GDUCC e todas as pessoas da sociedade civil que realizam projetos de intervenção no cárcere que contribuíram para esta pesquisa, pela coragem de vivenciar a reintegração social a partir de um caminho que está sendo definido pelo próprio caminhar.

Aos meus amigos arquianos, que elegi como família, cuja simples presença na minha vida é de um carinho e conforto sem tamanho, com eles estou sempre em casa. A todos do Instituto Ser Humano que me lembram com doçura do que sou feita.

À minha irmã Adriana, que há muitos anos vêm trilhando comigo o caminho do coração, e que por minha sorte, optou também por trabalhar com os sistemas punitivos (ou contra eles). Ao meu irmão Gabriel, que, com suas provocações sempre pertinentes, me desafia à profundidade. E à Thais, minha irmãzinha em Barcelona, cujo carinho tantas vezes me reconfortou em terras distantes.

A minha mãe, Licinha, mulher guerreira e generosa, por sua capacidade excepcional em conciliar controle e liberdade. Ao meu pai, seu Braga, eterno professor, que desde pequena me convida a entrar no universo dos livros e da doçura, e sutilmente me influencia a trilhar caminhos antes percorridos por ele.

Ao meu marido, que com sua presença sempre amorosa, trouxe leveza à minha vida (e à edição deste trabalho).

A todos que inspiraram e participaram diretamente ou indiretamente desta pesquisa, cuja coragem e ousadia me lembram que as coisas podem ser de outro modo. 
"Como si todas las sociedades dieran a entender que todo lo que es, incluso lo mas aparentemente intocable, podría ser de otro modo, o ser al revés, o no ser" (Delgado, 1999: 20) 


\title{
RESUMO
}

A presente tese tem como objeto a análise das intervenções da sociedade civil no cárcere à luz do conceito de reintegração social. A partir de um estudo de campo, apresento e comparo alguns projetos de intervenção em estabelecimentos prisionais de São Paulo e da Catalunha. Busquei sistematizar algumas experiências de reintegração social, buscando compreender as formas e impactos de diversos projetos que propõem reaproximação sociedade civil-cárcere. O objetivo foi conhecer algumas das formas que a sociedade civil tem se relacionado com o cárcere, de forma a compreender quais estratégias, discursos e práticas são mobilizadas na intervenção da sociedade nesse espaço. E ainda se, a partir dessas ações, pode-se afirmar que o cárcere está se abrindo à sociedade e vice-versa.

Palavras chave: prisão - reintegração social - sociedade civil- intervenção- voluntariado

\begin{abstract}
This thesis has as object the analysis of civil society interventions in prison in the light of the concept of social reintegration. From a field study, I present and compare some intervention projects in prisons in Sao Paulo and Catalonia. I tried to systematize some experiences of social reintegration, seeking to understand the forms and impacts of various projects that propose rapprochement civil society-jail. The aim was to study some of the ways that civil society has been involved in the prison, in order to understand what strategies, speeches and practices are mobilized in the intervention of society in that space. And still, from these actions, it can be said that the prison is opening up to society and the society is opening to prison and vice versa.
\end{abstract}

Keywords: prison- social reintegration- civil society - intervention - volunteering 


\section{LISTA DE SIGLAS}

AASP- Associação dos Advogados de São Paulo

ASP- Agente de Segurança Penitenciária

CDP- Centro de Detenção Provisória

CEJFE - Centre d'Estudis Jurídics i Formació Especialitzada

CNJ- Conselho Nacional de Justiça

CNPCP- Conselho Nacional de Política Criminal e Penitenciária

CPP- Centro de Progressão Penitenciária

CRBC- Comando Revolucionário Brasileiro da Criminalidade

DEPEN - Departamento Penitenciário Nacional

FAS- Fundació Autònoma Solidària

FDUSP - Faculdade de Direito da Universidade de São Paulo

FESP - Fundação Escola de Sociologia e Política de São Paulo

GIP- Group d'informacion sur les prisons

GDUCC- Grupo de Diálogo Universidade-Cárcere- Comunidade

IACC- Instituto de Ação Contra Cena

IBCCRIM- Instituto Brasileiro de Ciências Criminais

INCAVOL - Institut Català de Voluntariat

ITTC- Instituto Terra, Trabalho e Cidadania

KROM - Norsk Forening for Kriminalreform

LEP- Lei de Execução Penal

ONG- Organização não governamental

OSPDH- Observatori del Sistema Penal i els Drets Humans de la Universitat de Barcelona

PAM- Penitenciária Desembargador Adriano Marrey

PCC - Primeiro Comando da Capital

PFB- Penitenciária Feminina do Butantã

PFC- Penitenciária Feminina da Capital

PFS- Penitenciária Feminina Santana

PIP- Programa per a la Integració dels Presos

PJPN- Penitenciária José Parada Neto

RDD - Regime Disciplinar Diferenciado

SAP- Secretaria de Administração Penitenciária do Governo do Estado de São Paulo

SSPRJ- Secretaria de Serveis Penitenciaris, Rehabilitació i Justícia Juvenil Generalitat de

Catalunya

TPS- Taula de Participació Social

UAB- Universitat Autònoma de Barcelona

UB- Universitat de Barcelona

USP- Universidade de São Paulo

VEC- Vara de Execução Penal 


\section{SUMÁRIO DA TESE}

INTRODUÇÃO

PARTE I -

PRISÃO E SOCIEDADE: REINTEGRAÇÃO SOCIAL

CAPÍTULO 1 REINTEGRAÇÃO SOCIAL

1.1. Alguns apontamentos acerca do discurso contemporâneo das funções da pena de prisão

1.2. A reabilitação em crise?

1.3. Crise do ideal ressocializador: momento estratégico para desvelar

a irracionalidade da prisão

1.4. Reintegração social e as "ideologias res" 27

1.5. Significando a reintegração social 31

1.6. Bases teóricas para um trabalho de reintegração social 37

1.7. Reintegração social: uma síntese 46

CAPÍTULO 2 SOCIEDADE CIVIL, ESTADO E PRISÃO 48

2.1. Conceito de sociedade civil 48

2.2. Sociedade civil, punição e reintegração $\quad 52$

2.3. Poder público, sociedade civil e reintegração social 56

2.4. Participação da comunidade na LEP e órgãos da execução penal no Brasil 57

2.5. Reintegração social e o setor público 64

2.6. Regulamentação do trabalho voluntário: normativa nacional e internacional 72

2.7. O voluntariado na prisão $\quad 74$

2.8. Impacto do voluntário Penitenciário 77

2.9. O limite da atuação e a "síndrome do voluntariado queimado"

CAPÍTULO 3 AÇÃO E REFLEXÃO: QUANDO A ACADEMIA

\section{VAI À PRISÃO}

85

3.1. Prisão: espaço de resistência $\quad 85$

3.2. O papel do intelectual 86

3.3. A atitude crítica 88

3.4. Abolicionismo Acadêmico 89

3.5. O diálogo enquanto um caminho 90

3.6. Na prisão e contra ela: recusa e resistência 91

3.7. Experiências referências: GIP e KROM 92

3.8. A universidade e a prisão na atualidade 110

CAPÍTULO 4 METODOLOGIA E LINHAS DE ANÁLISE DO CAMPO 117

4.1. Ponto de partida: marcos biográficos $\quad 117$

4.2. Metodologia da pesquisa empírica 120

4.3. Marcos temporais e espaciais 120

4.4. Etapas da pesquisa nos campos: pesquisa exploratória, seleção dos projetos e análise empírica

4.5. Técnica e roteiros de entrevista 124

4.6. Linhas de análise do campo 128

4.7. Referenciais teóricos 134 
CAPÍTULO 5 TRAVESSIA ETNOGRÁFICA

5.1. Travessias

5.2. A necessidade etnográfica

$\begin{array}{lr}\text { 5.3. Reconhecendo o terreno } & 150\end{array}$

5.4. Reconhecida pelo terreno 151

5.5. Negociação com o campo 152

5.6. Eleição de um tema "vendável" 153

5.7. Estratégias de entrada 155

5.8. Alcance das estratégias 157

5.9. Um relato etnográfico: Visita a La Modelo 158

5.10. Apresentação das entidades do campo catalão 168

CAPÍTULO 6 PRISÃO E VOLUNTARIADO NA CATALUNHA

6.1. Sociedade civil e prisão na Catalunha 182

6.2. Administração prisional e entidade da sociedade civil 194

6.3. Motivações e percepções dos presos 204

$\begin{array}{ll}\text { 6.4. O papel do voluntário por ele mesmo } & 217\end{array}$

6.5. O preso pelos olhos do voluntário: algumas representações 223

6.6. Dentro ou fora do jogo: uma tipologia das estratégias de resistência 225

PARTE III-

EXPERIÊNCIAS DE REINTEGRAÇÃO SOCIAL NAS PRISÕES PAULISTAS

\section{CAPÍTULO 7 EXPERIÊNCIAS DE REINTEGRAÇÃO SOCIAL} NO ESTADO DE SÃO PAULO

7.1. Desenvolvimento e limites da pesquisa no campo paulista 235

7.2. Quadro-resumo das experiências selecionadas 238

7.3. Roteiro de Apresentação dos Projetos 239

7.4. "Quem somos nós? 239

7.5. "Curso transdisciplinar de criminologia penitenciária e execução penal” 249

$\begin{array}{ll}\text { 7.6. "Projeto Leiturativa" } & 259\end{array}$

7.7. "TV Cela" 269

7.8. A perspectivas de gênero nos projetos de reintegração social em São Paulo 275

\section{CAPÍTULO 8 GDUCC: UMA PROPOSTA DE DIÁLOGO} UNIVERSIDADE, CÁRCERE E COMUNIDADE

8.1. O significado especial desse capítulo: o fim e o início 284

8.2. "Grupo de Diálogo Universidade-Cárcere-Comunidade" - USP:

apresentação do projeto 286

8.3. A mobilidade dos participantes: o grupo em permanente construção 298

8.4. Motivações dos participantes do projeto 302

8.5. Impactos do GDUCC: algumas percepções das pessoas envolvidas $\quad 309$

$\begin{array}{ll}\text { 8.6. Jogo de cena } & 318\end{array}$

8.7. Movimento inacabado e experiência de aprendizagem: alguns temas 347 
BIBLIOGRAFIA

ANEXO 1 - PESQUISA EXPLORATÓRIA

ANEXO 2 -CONVÊNIOS FIRMADOS PELO DEPEN ENTRE 2004-2006 


\section{INTRODUÇÃO}

A presente tese é resultado de três anos da pesquisa de doutoramento "Reintegração social: discursos e práticas na prisão -Um estudo comparado". Busquei compreender as formas e impactos dos projetos de reaproximação sociedade civil-cárcere, e sistematizar algumas experiências de reintegração social desenvolvidas por entidades da sociedade civil em estabelecimentos prisionais de São Paulo e da Catalunha (Espanha).

O doutorado foi realizado no programa de Pós-Graduação do Departamento de Direito Penal, Criminologia e Medicina Forense da Universidade de São Paulo, com o período de dez meses de estágio doutoral no Departamento de Antropologia da Universitat de Barcelona ${ }^{1}$.

Esta pesquisa partiu do desejo de "fazer alguma coisa" pelo (e portanto, dentro da minha perspectiva, contra) o sistema prisional, uma tentativa de por luz em "projetos que fazem do cárcere menos cárcere". A escolha desse foco atendeu a uma forte expectativa pessoal de encontrar grupos para compartilhar experiências de atuação no cárcere, na coordenação adjunta do Grupo de Diálogo Universidade- Cárcere- Comunidade (GDUCC), buscando principalmente aqueles que partiam de pressupostos e de posicionamentos parecidos com os meus.

Dada a dimensão pessoal desse trabalho, que também acompanha a trajetória e o recorte da presente pesquisa, optei pelo uso da primeira pessoa do singular na presente tese. Assumo essa escolha ciente de alguns perigos que ela traz. De forma geral, tentei evitar tom personalista na linguagem e nas análises, ainda que em alguns momentos da tese tenha propositadamente exposto a dimensão confessional e pessoal das minhas reflexões. Ademais, não pretendi com essa escolha, excluir o coletivo de pessoas que contribuíram para a construção das reflexões aqui apresentadas, em especial o orientador da presente pesquisa, e outros professores e colegas que foram fundamentais para a elaboração deste texto.

Meu objetivo foi conhecer algumas das formas com que a sociedade civil, paulista e catalã, tem se relacionado com o cárcere. Compreender quais estratégias, discursos e práticas são

${ }^{1}$ De setembro de 2010 a junho de 2011, durante o qual gozei de bolsa sanduíche (PDEE) CAPES- Fundación Carolina. 
mobilizadas na intervenção da sociedade nesse espaço. E ainda, se, a partir dessas ações, pode-se afirmar que o cárcere está se abrindo à sociedade e vice-versa.

Para tanto, utilizei metodologia qualitativa de pesquisa. Realizei entrevistas semidirigidas com os envolvidos, direta e indiretamente, com os projetos (voluntários, , presos, diretores de entidades, funcionários da prisão), pesquisa documental (projetos, memoriais, manuais) e alguns relatos etnográficos do trabalho desenvolvido pelas entidades selecionadas.

Em substituição às tradicionais metas de reeducação e ressocialização, o criminólogo italiano Alessandro Baratta propõe a "reintegração social". A reintegração constitui uma "via de mão dupla", a abertura de um processo de comunicação a partir do qual os presos se reconheçam na sociedade e esta se reconheça na prisão, sendo que ambos têm responsabilidade por essa reaproximação (Baratta, 1990).

De acordo com Sá (2007), a relação entre as pessoas que compõem a população carcerária e a sociedade de forma geral é pautada em um antagonismo histórico. O encarceramento, enquanto reposta social e seletivo à ação desviante, atualiza e fortalece esse antagonismo. A (re) integração entre sociedade e prisão só é possível a partir do envolvimento e corresponsabilização da comunidade pelos conflitos surgidos em seu seio.

A abertura da sociedade para o cárcere e do cárcere para a sociedade possibilitaria que ambos compartilhassem e dividissem a responsabilidade pela restauração da relação entre a sociedade e aqueles que, geralmente, possuem com ela uma "história de conflito" (Sá, 2007).

No Brasil, pouco material empírico foi produzido no âmbito do Direito a partir dos nossos cárceres. A escassez de produções nesse âmbito deve-se tanto à falta de tradição do meio jurídico em elaborar pesquisas de campo quanto às exigências burocráticas ${ }^{2}$ que, não por acaso, difícultam a inserção do pesquisador na prisão.

\footnotetext{
2 No Estado de São Paulo, o acesso aos estabelecimentos prisionais passou a ser mais difícil a partir da presença declarada das facções criminosas nos presídios (principalmente PCC). Inclusive, de 2007 a 2010, os dados do sistema prisional do Estado (número de presos, regime, pena) não foram publicizados.
} 
A insuficiência de debates acadêmicos e sociais sobre o tema da execução da pena contribui para que a produção das verdades no campo penal fique concentrada nas mãos daqueles que o administram.

Nesse sentido, mostra-se indiscutível a importância social do estudo deste tema. A prisão ocupa um lugar simbólico, e muitas vezes concreto, na vida de todos na sociedade. Uma pesquisa que se proponha a analisar algumas formas inovadoras de membros da sociedade civil relacionarem-se com o cárcere pode inspirar o surgimento de novas ações, contribuir para a sistematização de outros projetos, e ainda, ajudar na reflexão das práticas até então adotadas.

Essa pesquisa pode trazer uma contribuição original à ciência jurídica brasileira ao traçar diretrizes e pressupostos da reintegração social, a partir de um panorama das atividades que vem sendo realizadas em sede de execução penal. Ao analisar os projetos de reintegração social, suas práticas, limites e pressupostos, a presente pesquisa pode vir a trazer uma contribuição ao debate acadêmico, destacando a questão da execução penal e as formas de intercâmbio entre sociedade civil e cárcere.

A presente tese é composta por três partes: Parte I -Prisão e sociedade: reintegração social; Parte II- Travessia etnográfica: Voluntariado nas prisões da Catalunha; e Parte IIIExperiências de reintegração social nas prisões paulistas.

A Parte I é formada pelos primeiros quatro capítulos. Nos Capítulos 1, 2 e 3 discuto o conceito de reintegração social e as relações entre Estado, prisão e sociedade civil no contexto da execução penal. E, no Capítulo 4, apresento a metodologia de pesquisa de campo utilizada na produção dos dados apresentados nos capítulos seguintes da tese.

No Capítulo 1, irei me deter especificamente na temática da reintegração social. De início, analisarei o discurso contemporâneo acerca das funções da pena de prisão e a crise que o ideal de reabilitação atravessou a partir dos anos 80 do século XX. Em seguida, trabalharei o conceito de reintegração social, suas diferenças em relação às chamadas "ideologias res", e seu uso nos discursos acerca da prisão. Ao final, estabelecerei algumas bases teóricas 
para um trabalho de reintegração social, a partir das teorias de Eugênio Raul Zaffaroni (ARG), Alessandro Baratta (ITA), Antonio Beristain (ESP) e Alvino Augusto de Sá (BRA).

O eixo do Capítulo 2 é a relação entre o Estado, sociedade civil e instituição prisional. Abordarei o conceito de sociedade civil, seus usos e sua relação com o Estado. Em seguida, farei uma reflexão acerca de como a punição atinge a sociedade, e como se pode, a partir dela (sociedade), alcançar a reintegração social. Nesse sentido, analisarei alguns aspectos do trabalho voluntário nas prisões: regulamentação, finalidades, impacto e limites.

No Capítulo 3, proponho uma reflexão acerca do posicionamento da academia em relação à prisão, a partir das atitudes de recusa e resistência. Para pensar a atitude crítica do intelectual frente à problemática do encarceramento, recorrerei a duas experiências históricas que considero referências: GIP (Group d'information sur les prisons) e KROM (Norsk Forening for Kriminalreform). Ao final, apresentarei algumas reflexões acerca da relação universidade-prisão na atualidade.

Encerro a Parte I desta tese com o Capítulo 4, aonde explicitarei a metodologia de pesquisa e linhas de análise de campo que deram forma aos próximos quatro capítulos, que compõem as Partes II e III. De início, demarcarei o ponto de partida e os marcos para delimitação do campo de pesquisa. Em seguida, explicitarei as etapas de pesquisa de campo, assim como o método e roteiros de entrevista. Ao final, apresento algumas linhas de análise que me guiaram no recorte e análise do material, assim como referenciais teóricos que contribuíram para a compreensão e interpretação da realidade estudada.

A Parte II da tese, composta dos Capítulos 5 e 6, corresponde às pesquisas e reflexões advindas do estágio sanduiche na Universitat de Barcelona. A partir de uma curta e localizada incursão (setembro de 2010 a junho de 2011), tentei compreender o fenômeno do voluntariado, forma institucionalizada de entrada da sociedade civil nas prisões catalãs, identificando proximidades e distâncias em relação ao sistema prisional paulista.

Relato, no Capítulo 5, minha inserção no campo de pesquisa catalão e alguns resultados da pesquisa de campo realizada durante o segundo semestre de 2010 e o primeiro semestre de 2011. No início, descrevo o meu processo de inserção no campo penitenciário da 
Catalunha: estratégias, dificuldades, negociações, etc. Descrevo algumas percepções da configuração do campo (de força e de luta) nesse território, a partir do que denominei travessia etnográfica: o contato com outra cultura para compreender como a ação no cárcere se produz em outros contextos.

No Capítulo 6, apresentarei algumas reflexões advindas da pesquisa de campo realizada na Catalunha. No período de dez meses de estágio, além de ter participado de inúmeros seminários, encontros, cursos, e visitado seis diferentes centros penitenciários, realizei entrevistas com coordenadores de projetos, voluntários, presos, entre outros envolvidos com o sistema penitenciário local. Os temas e categorias a que recorro nesse capítulo foram construídos a partir dessas experiências nos campos acadêmico, burocrático-estatal e prisional catalães.

Nos Capítulos 7 e 8, que formam a Parte III desta tese, apresento algumas experiências de reintegração social no campo paulista. O universo empírico de investigação no Estado de São Paulo desenvolvidos pela sociedade civil no período de realização desta pesquisa, ou seja, de janeiro de 2009 até dezembro de 2011.

Inicio o Capítulo 7 expondo o desenvolvimento e limites da pesquisa no campo paulista. Em seguida, apresento quatro experiências de intervenção nos cárceres paulistas, a partir de um roteiro comum de apresentação dos projetos.

Finalizo a presente tese, no Capítulo 8, abordando experiências e reflexões em torno do Grupo de Diálogo Universidade- Cárcere- Comunidade (GDUCC), hoje Projeto de Extensão da Faculdade de Direito da USP. O objetivo desse capítulo é produzir uma reflexão teórica e crítica acerca dessa proposta de intervenção no cárcere, de forma que as práticas do grupo possam ser repensadas à luz da teoria, de outros projetos, e mesmo da voz daqueles que dele participam.

Ao final, a partir do conjunto de experiências de intervenção no cárcere e das problemáticas relacionadas a essa temática, espero ter colaborado com algumas reflexões que sirvam à construção e implementação de projetos de reintegração social. 


\section{$\underline{\text { PARTE I }}$}

\section{PRISÃO E SOCIEDADE: REINTEGRAÇÃO SOCIAL}

\section{CAPÍTULO 1 REINTEGRAÇÃO SOCIAL}

Neste capítulo, irei me deter especificamente na temática da reintegração social. De início, analisarei o discurso contemporâneo acerca das funções da pena de prisão e a crise que o ideal de reabilitação atravessou a partir dos anos 80 do século XX. Em seguida, trabalharei o conceito de reintegração social, suas diferenças em relação às chamadas "ideologias res", e seu uso nos discursos acerca da prisão. Ao final, estabelecerei algumas bases teóricas para um trabalho de reintegração social, a partir das teorias de Eugênio Raul Zaffaroni (ARG), Alessandro Baratta (ITA), Antonio Beristain (ESP) e Alvino Augusto de Sá (BRA).

\subsection{Alguns apontamentos acerca do discurso contemporâneo das funções da pena}

O discurso jurídico acerca das funções da pena de prisão reveste de racionalidade essa forma de punição. Justifica e matiza a dor dos apenados, além de encobertar outras funções sociais e econômicas que a prisão exerce em nossa sociedade.

A partir das últimas décadas do século passado, este discurso tem passado por ao menos duas importantes releituras. A primeira remete-se ao declínio das funções instrumentais da pena, contraposto ao crescente interesse nas funções simbólicas de reforço da norma e dos valores sociais (prevenção geral positiva). A segunda advém de um descrédito de todas as funções preventivas da pena, e da ascensão do discurso retributivo, deixando como fim único e inconteste da punição o castigo, na forma da neutralização do preso.

De certa forma, o discurso de instrumentalização da pena de prisão, que atribui a esta a função de reforma do indivíduo e de prevenção de novos crimes, contribui para que seja mantida oculta a brutalidade do castigo. $\mathrm{O}$ uso da violência pelo sistema penal não é, de forma geral, percebido pela população externa a ele, e as teorias da pena contribuem para esse processo: ofuscam as violências a partir da racionalidade de seu discurso. 
Para Álvaro Pires ${ }^{3}$, professor da Universidade de Ottawa no Canadá, a crise na lógica da reabilitação contribuiu para um incremento da responsabilidade individual e da lógica retributiva. No imaginário social e institucional, o indivíduo socialmente vulnerável é substituído pela figura do inimigo ${ }^{4}$. Consequentemente, a prisão passa a rever suas tradicionais justificativas, cunhadas anteriormente pelo discurso iluminista e utilitarista.

A submissão do indivíduo ao poder institucional e a imposição do sofrimento parecem ser características que sempre acompanharam a história da prisão. Hulsman (1993: 87) elenca dois elementos como característicos da pena, tal como é entendida pela civilização ocidental: uma relação de poder entre aquele que pune e aquele que é punido, que por sua vez reconhece a autoridade do primeiro; e depois, imposição de doses de sofrimento, penitência, dor.

Ainda que se fale do fracasso da pena de prisão, é indiscutível o êxito da instituição penitenciária em impingir sofrimento a (alguns) indivíduos em retribuição ao dano que causaram à sociedade. $\mathrm{O}$ sofrimento do apenado está implícito na aplicação da pena.

Para além da retribuição (do mal por outro mal necessário), os discursos acerca das funções da pena podem ser divididos em dois grupos: no primeiro estariam os enunciados criados pela dogmática penal tradicional- as funções declaradas da pena- que prescrevem um dever ser e que legitimam o funcionamento de justiça; no outro, estariam as funções não declaradas da pena, descritas a partir da análise da economia da pena em relação aos sistemas econômicos e sociais de determinada época e sociedade ${ }^{5}$.

É importante situar o conceito da reintegração social nos discursos das finalidades da pena. Ainda assim, o objetivo da presente pesquisa não é retomar as teorias tradicionais acerca das funções da pena.

\footnotetext{
${ }^{3}$ Curso Criminologia e Justiça Penal, IBCCRIM- SP , junho- julho de 2001.

${ }^{4}$ Inimigo na teoria do dogmático alemão Günter Jakobs é aquele que não respeita as regras do Estado de Direito e ameaça a sua ordem. Legitima-se, no âmbito do Estado, a criação da categoria de não pessoa, não cidadão e a própria crença de que existiriam pessoas essencialmente más, não merecedoras de uma atuação estatal equânime, transparente e democrática. Ver JAKOBS, Gunter e MELIÁ, Cancio (2003). Derecho penal del enemigo. Madrid: Cuadernos Civitas.

${ }^{5}$ Nesse sentido, imprescindível a leitura de Punição e estrutura social de Rusch e Kirchheimer, Vigiar $e$ Punir de Michel Foucault, Cárcere e Fábrica de Dario Mellossi e Mássimo Pavarini.
} 
Três são os motivos pelos quais não me preocuparei em trabalhar especificamente com as funções da pena. O primeiro está no fato que diversas pesquisas no âmbito do direito já se centraram nessa temática, seja a partir de uma perspectiva filosófico-abstrata, seja a partir de uma perspectiva realista, para acusar a falência da pena de prisão e seu fracasso na tarefa de atingir os fins declarados aos quais se propõe ${ }^{6}$. O segundo é por não considerar a reintegração social como função da pena, mas como uma possibilidade de minimizar seus efeitos. O último, e talvez o mais importante, demarca uma escolha política de não reproduzir os discursos que insistem em justificar a pena atribuindo-lhe qualquer eficácia real além da retributiva, e nesse sentido, não me esforçar em construir um saber reafirmando os velhos discursos.

\subsection{A reabilitação em crise?}

Entre os anos de 1960 e 1970, no contexto do Estado de bem estar social da Europa Ocidental $^{7}$, a pena tinha a finalidade declarada de corrigir, inserir a ética do trabalho e reintroduzir os indivíduos dentro dos padrões socialmente aceitos. Esta concepção estava vinculada aos princípios que conformavam aquele tipo de Estado: a sanção teria que ir além da punição, e caberia ao Estado prover os meios para a reforma moral e social do apenado.

Ao mesmo tempo, a instituição penitenciária era alvo de sérias críticas, as quais pareciam apontar para uma redução do nível de encarceramento e do papel que a prisão exercia na sociedade.

A partir dos anos de 1980, as teorias da reabilitação começaram a perder força, abalando a hegemonia do discurso sobre punição da década anterior. Os especialistas não mais conseguiam sustentar as respostas técnicas dadas ao problema.

Para Garland (1999: 62), o mito fundante da modernidade- do Estado como provedor da segurança e da ordem- estaria em derrocada. As declarações do Estado no campo da repressão criminal se tornaram mais modestas e hesitantes.

\footnotetext{
6 Tarefa que já empreendi na pesquisa de mestrado. BRAGA, Ana Gabriela Mendes. Identidade do preso e as leis do cárcere. Dissertação de mestrado, FDUSP, 2008.

${ }^{7}$ No Brasil o enfraquecimento do discurso de ressocialização ocorreu um pouco mais tarde, no final dos anos 80 início dos 90.
} 
Na modernidade, o modelo do controle social disciplinar era composto pela fábrica, no âmbito econômico, pelo Welfare State como modelo social e o "correcionalismo" como paradigma penal. $\mathrm{Na}$ atualidade, nenhum destes elementos (econômicos, sociais e penais) se sustentam.

Jock Young (2002), ao analisar as transformações sociais ocorridas do final do século XX, diagnostica a transição de uma sociedade inclusiva para uma sociedade excludente, de uma sociedade que assimila e incorpora para outra que exclui. Segundo o autor, o outro na sociedade inclusiva não era visto como inimigo externo, mas como alguém passível de recuperação, que deveria ser reabilitado para ser incluído na sociedade; o discurso em voga era o da integração, com o estímulo da "osmose cultural dos menos socializados rumo aos bem socializados" (Young, 2002: 22).

A despeito da crise de legitimidade e das transformações sociais do fim do século passado, o discurso da reabilitação continua fazendo eco na discussão de política criminal. Porém, alguns autores, como Deleuze (1992:220), são radicais no diagnóstico de uma crise nos meios de confinamento, de uma mudança profunda no alcance e na forma do exercício de poder.

Deleuze (1992) afirma a substituição da sociedade disciplinar pela de controle, a partir, principalmente, da flexibilização da forma de sujeição do indivíduo ao poder. Enquanto os confinamentos em espaços fechados são moldes rígidos e fixos, os controles assumem a forma de modulação, cujo exercício é feito a partir de movimentos ondulatórios que atingem todo o corpo social. O controle total, que vinha sendo feito de forma concentrada em alguns espaços e direcionado a alguns indivíduos, expande-se para o exterior dessas instituições e alcança a população como um todo, indiscriminadamente.

$\mathrm{Na}$ contemporaneidade, as pessoas estão sujeitas à ação contínua dos mecanismos de visibilidade e às mais diversas formas de registro da sua existência. Os espaços de interação social são vigiados, e o conteúdo desta interação registrado: o conteúdo da comunicação feita por e-mail, blogs, espaços de bate papo virtual etc., é escrito e gravado; a popularização do uso dos cartões nas transações comerciais permite o detalhamento de como e onde o indivíduo emprega seu dinheiro; a disseminação de câmeras nos espaços 
públicos e privados faz com que o indivíduo tenha que sorrir a todo tempo porque pode estar sendo filmado.

De acordo com Young (2002: 34): "Na modernidade recente o outro desviante está em toda parte (...). Devido à insegurança ontológica, há tentativas de recriar uma base segura. Isto é, (...) ser rígido em vez de flexível ao julgar, ser punitivo e excludente ao invés de permeável e assimilativo".

Os reflexos desta mudança atingiram a própria racionalidade penal, com implicações na concepção da função da pena e na execução da mesma. A disciplina, que vigiava e conformava todos os atos da vida do condenado, passaria a dar lugar ao controle, que, longe de querer conformar sua existência, agiria no sentido de excluí-la. Os regimes de isolamento rígido e a propagação do controle para além dos muros institucionais, como, por exemplo, através do uso de pulseiras eletrônicas, podem ser tidos como manifestações desta nova dinâmica do poder.

Porém, ao contrário do que se poderia prever, a expansão do poder de controle para além dos muros prisionais não significou um enfraquecimento do papel que a prisão exerce em nossa sociedade: a instituição prisional ainda resiste enquanto pena por excelência (ao menos para determinados tipos de crimes e condenados). Apesar de hoje a prisão ainda ocupar um espaço de relevo, o discurso da finalidade da pena e a própria dinâmica prisional vêm sofrendo algumas transformações.

Na visão de Baumann (2000:32), a prisão contemporânea não é mais escola para nada. É a disciplina formal e pura, o laboratório da sociedade globalizada. Não importa o que os presos fazem dentro de suas celas, desde que permaneçam excluídos. Em uma sociedade tão volátil (que Bauman adjetiva como líquida), a impossibilidade do preso se comunicar e se movimentar cria na prisão uma temporalidade e uma espacialidade especificas, que muito diferem daquelas que regem o mundo fora dela.

Esta mudança é ilustrada com o exemplo de Pelican Bay $^{8}$ - prisão situada na Califórnia na qual os presos não têm contato cara-a-cara com os guardas ou outros presos. Eles ficam em

\footnotetext{
${ }^{8}$ No Brasil, as Penitenciárias Federais, mais especificamente as de Regime Disciplinar Diferenciado, ilustram bem o exercício do poder de controle.
} 
suas celas, não veem e não são vistos, incomunicáveis. Mas, antes de considerá-la como uma versão "high-tech" do panóptico de Bentham, Baumann nos chama para uma análise mais depurada.

As prisões teriam se distanciado da reforma ética que as instituições panópticas queriam promover. A função do panóptico, e dos mecanismos disciplinares em geral, consistia em reenquadrar o indivíduo nos padrões sociais, reinserindo-o na ética do trabalho. Contudo, com a nova configuração econômica e social da pós-modernidade, caracterizada pelo desemprego, excesso de mão de obra e flexibilização das relações de trabalho, a imposição dos comandos éticos do trabalho teria perdido o sentido.

Sob esta perspectiva, a aceitação da ética do trabalho não seria mais condição para a reinserção social do preso. Já que houve sensível redução na demanda por mão de obra, não haveria necessidade de que o preso (ao sair da instituição ou ainda dentro dela) esteja docilizado para o trabalho. De acordo com De Giorgi (2006: 19), não existe mais projeto de disciplinamento porque os estratos sociais mais baixos não são mais elementos centrais no processo produtivo.

A reforma individual de outrora teria sido substituída pela contenção preventiva. A prisão funcionaria no sentido de desestruturar a potência do indivíduo, desarmando-o de qualquer possibilidade de rebelião ou resistência. De acordo com Bauman (1999: 116), "um isolamento total reduziria o outro a uma pura personificação punitiva da lei”.

Apesar de todas essas transformações, mesmo que os mais conservadores não creditem à pena de prisão a possibilidade de mudar ("para melhor") a personalidade de alguém, o sonho da ressocialização continua ecoando em alguns discursos e práticas na prisão. Os discursos midiáticos, populares e acadêmicos concebem a prisão como lugar de transmissão de modelos desviantes (a chamada "escola do crime"), ao mesmo tempo em que alimentam a esperança de reinserir o indivíduo na sociedade por meio da prisão.

Logo, o alcance do diagnóstico acerca do fim do ideal da reabilitação deve ser relativizado. Certamente, houve algumas mudanças no exercício do poder de punir, porém elas não permitem que façamos afirmações categóricas no sentido de que o projeto de disciplinamento e a ética do trabalho foram substituídos integralmente pela cultura do 
controle. A ideologia do tratamento continua sendo usado como estratégia de governo e manutenção da ordem.

O discurso disciplinar ainda ocupa um lugar importante na disputa pela verdade em torno da punição, assim como os projetos de readequação ética do preso a partir da perspectiva da educação e do trabalho.

Especificamente no Brasil, os estabelecimentos prisionais que funcionam sob a lógica estrita do controle, com o domínio pelo Estado da dinâmica prisional, são uma exceção. Podemos perceber a manifestação dessa nova forma de poder no Sistema Penitenciário Federal, e de forma mais acentuada no Regime Disciplinar Diferenciado (RDD).

Porém, essa forma de exercício do poder de punir contrasta com a realidade dos presídios brasileiros, marcados pela superlotação, pelo controle dos presos da dinâmica prisional e pela existência de certas liberalidades. O controle, e mesmo a disciplina, ocorrem mais pela ação dos próprios presos do que pela via estatal. O Estado não inclui nem exclui completamente, e nossas prisões continuam sonhando o sonho da reabilitação.

Apesar do Brasil nunca ter concretizado o paradigma da reabilitação, este é até hoje invocado como princípio norteador da nossa execução penal. Há uma funcionalidade em manter este discurso em voga, ainda que sem perspectiva de sua realização concreta. Fecho (mas sem concluir) esta reflexão, com palavras de Wanda Capeller, escritas em meados da década de 80, mas pertinentes ainda hoje:

"Na sociedade brasileira, hoje, o conceito de ressocialização estaria falido? Aparentemente, em uma resposta ingênua, diríamos que sim. Mas, na verdade, ele é sempre requisitado de modo novo, transformado e transposto para uma nova utilidade. Quando o sistema penitenciário mostra, pelo exercício real da violência sua verdadeira face apressam-se os políticos e administradores do sistema em resgatar o conceito de ressocialização, (...) apresentam o mito da ressocialização como a única possibilidade dos indivíduos alijados serem felizes novamente e retornarem ao convívio social"

(Capeller, 1985: 132)

Antes de entrar em algumas especificidades do sistema prisional da Catalunha, cabe situálo em um contexto mais amplo, no debate contemporâneo acerca das mudanças no alcance e na forma do exercício de poder. 
Diversos autores tem analisado o que se chama a crise de um modelo disciplinar e a ascensão de mecanismos de controle e gestão das populações. Entre eles, Garland (1999), Young (2002), Deleuze (1992), Bauman (2000), De Giorgi (2006), Wacquant (2001) e Chantraine (2006), cujas reflexões conformam o referencial teórico da presente tese ${ }^{9}$.

Essas abordagens distintas compartilham entre si um mesmo diagnóstico: o emprisionamento contemporâneo visa algo além da reforma do preso. Durante o século XX, o ideal de reabilitação manteve sua hegemonia manifesta nas práticas e discursos acerca da prisão a partir de uma relação paradoxal (mas nem por isso desarmônica) com o objetivo de contenção- que é fundacional e intrínseco à própria instituição carcerária.

As práticas correcionalistas de então objetivavam a transformação do indivíduo por meio da ação sobre seu corpo e alma. As instituições disciplinares nascem para reformar, curar, educar, corrigir, recalcar; atuar com o fim de produzir certas individualidades, adestrar os corpos para deles extrair uma utilidade.

A premissa do correcionalismo de que o preso (e outros desviantes) seriam vidas que precisavam ser salvas, deve ser relida nos dias de hoje à luz da emergência dos mecanismos atuariais que conformam as subjetividades sob controle: gestão de risco, classificação, gerenciamento.

Gilles Chantraine (2006: 276), ao analisar o sistema penitenciário canadense, propõe uma releitura do paradoxo reabilitação-contenção. A partir da compreensão de que essa aparente separação (écartèlement) entre estas duas missões da pena de prisão se reveste de uma coerente estratégia e se inscreve de maneira especifica em um continuum sécuritaire.

O autor inscreve esta "nova penalogia" em um projeto não mais disciplinar, mas de controle, e a denomina pós-disciplinaria ou governamental. Dentro desta perspectiva, não importa a produção de um sujeito disciplinado, mas de um sujeito que conheça e gerencie seus riscos. A ação dos mecanismos de governança incita o indivíduo a identificar os riscos do comportamento criminoso, e produzir recursos para contê-los.

\footnotetext{
${ }^{9}$ Conforme já analisado no capítulo 2 da tese.
} 
Dentro deste processo de constituição de sujeito, uma tendência já manifesta no campo penitenciário europeu é o incremento da classificação dos estabelecimentos prisionais e aperfeiçoamento das ferramentas de categorização dos indivíduos.

Ao preso são outorgados lugares e posições distintas em âmbito prisional, de acordo com o risco que apresenta para a prisão e para a sociedade. Os presos de pouco, médio e grande risco tem seu correspondente nas prisões de mínima, média e alta segurança; além dos indivíduos "complicados", que merecem unidades especiais de detenção. E, dentro delas, inúmeros programas, planos de tratamento, estratégias desenhadas para o governo da população penitenciária.

Esse domínio da "l'expertise psychosociale" (Chantraine, 2006:282) efetua-se através de um entrelaçamento de saberes clínicos clássicos com um conjunto de saberes e técnicas de avaliação e gestão dos "riscos criminógenos".

Um dos mecanismos centrais dessa forma de governo da prisão, que não só se mantém na atual conjuntura, mas se aperfeiçoa, é o sistema de prêmios e castigos, ou de privilégios (Goffman, 1974: 50). Por esse sistema, as regalias do sistema prisional são obtidas pelo preso através da obediência, em ação e espírito, à equipe dirigente. Ao mesmo tempo, a instituição, para castigar o preso, ataca esses mesmos privilégios, vetando seu acesso temporária ou permanentemente.

Chantraine (2006: 283) identifica, no sistema penitenciário de Quebec, o funcionamento de um sistema de privilégios individuais e coletivos, um mecanismo de penas e recompensas, chamado ali système bonbon ${ }^{10}$. A base desse sistema está em oferecer um conforto relativo sobre condições de privações estritas, ao mesmo tempo que instrumentaliza as margens da autonomia dos presos.

\footnotetext{
${ }^{10}$ Em francês bonbon designa bala.
} 
A analogia dos privilégios com "doces" não me parece gratuita; primeiro porque vão ao encontro do processo de infantilização do interno; depois, porque esses privilégios constituem uma forma de fazer menos amargo o cumprimento de pena ${ }^{11}$.

Para os presos quebequenses, esse sistema possibilita "de faire du meilleur temps", ou como diriam os presos no Brasil "tirar melhor a cadeia". Aderir a esse sistema é, na maior parte das vezes, o único caminho para o preso "respirar alguma rua", tatear alguma liberdade desde o confinamento, seja por meio de uma progressão de regime de pena, uma liberdade condicional, uma autorização para visita (vis-à-vis), uma vaga em uma oficina de trabalho etc.

O sistema de privilégios constitui peça importante na tecnologia de controle da prisão e no governo da vida dos presos. A "governamentalidade", à qual se refere Foucault (2008), é gestada por meio de técnicas e regulações de conduta visando a produção de subjetividades específicas. Como bem sintetiza a frase de um agente penitenciário reproduzida por Chantraine (2006: 284) “dividir para melhor reinar". 12

Contudo, esse jogo possui sua perversidade, uma vez que seus jogadores são compelidos a entrar nele sozinho, pensar estratégias individualmente, e mostrarem-se cooperativos com a equipe dirigente. Isto significa mostrar-se ao lado dos que ditam as regras, e longe daqueles que as obedecem; estar perto das classes, oficinas, salas de exame, e distante do pátio.

Como parte desta estratégia perversa, os dirigentes aliam-se aos lideres dos presos ${ }^{13}$ para melhor controlar os outros presos. Para Chantraine (2006:284), a produção institucional do controle é delegada pela direção aos líderes- estes conhecidos como "police du pen", ; que a exercem sobre arbitrariedade e força física, com o fím de manter seus próprios privilégios

\footnotetext{
${ }^{11}$ Nos cárceres brasileiros, o bombom (chocolate) é produto muito valorizado, talvez por exercer a função (literalmente) de adoçar a vida.

${ }^{12}$ No original "diviser pour mieux régner".

${ }^{13}$ Tema que aprofundei em pesquisa anterior (Braga, 2008).

${ }^{14} \mathrm{Pen}=$ pénitencier, logo, polícia penitenciária.
} 
Para o funcionamento deste modelo pós-disciplinar, faz-se necessária a construção de uma maquinaria de governo. O aperfeiçoamento do exercício desse tipo de poder na prisão ocorre por meio do aperfeiçoamento de ferramentas de gestão da vida prisional, pressupondo assim: a ampliação do alcance das instituições (tanto pelo aumento de estabelecimentos prisionais, como de instituições atuantes na prisão); aumento e especialização de pessoal penitenciário; ampla oferta de programas; planejamento e avaliação de atividades; criação e demarcação de espaços; incremento das regras etc.

Esse modelo pressupõe um relativo aumento do número de pessoas que circulam na prisão, e, consequentemente, um incremento na disputa de "modos de fazer" a execução penal. Para Salle (2004: 13), isso significa mise à l'épreuve de la prison, ou seja, a prisão colocada à prova pela sociedade civil, que obriga a instituição penitenciária a refundar sua legitimidade através da adaptação e incorporação da critica externa à instituição. Nas palavras do autor:

"A emergência do modelo pós-disciplinar é assim correlativo a um movimento de abertura, de complexificação da vida social e multiplicação relativa dos atores sobre a cena carcerária, através da qual a administração penitenciária (...) conseguiu integrar a crítica da qual ela tem sido objeto em um modelo de gestão carcerária renovado"15

(Chantraine, 2006: 278)

A complexificação da cena carcerária depende da conjunção de duas vontades políticas:

1) da sociedade civil querer ocupar esse espaço; 2) da prisão se abrir para circulação, e principalmente, permitir a presença nos seus espaços de pessoas estranhas à instituição.

\subsection{Crise do ideal ressocializador: momento estratégico para desvelar a irracionalidade da prisão}

Alguns autores defendem a manutenção da perspectiva da reabilitação, ainda que reconhecida sua inocuidade, como limite à ação estatal e garantia de preservação das condições mínimas de encarceramento.

15 Tradução livre. No original: "L'émergence du modèle post-disciplinaire est ainsi corrélative d'un mouvement d'ouverture, de complexification de la vie sociale et de multiplication relative des acteurs sur la scène carcérale au travers duquel l'administration pénitentiaire (...) est parvenue à intégrer la critique dont elle a été l'objet dans un modèle de gestion carcérale renouvelé" 
Quando uma política pública não funciona, deve haver um problema em sua implementação (conjuntura) e/ou na teoria sobre a qual ela se sedimenta (estrutura). Certamente, além das questões estruturais, há diversos problemas conjunturais nos programas de reabilitação criminal.

Visto isto, Garland ${ }^{16}$ defende que, ao invés de se abandonar a perspectiva da reabilitação, dado o seu insucesso prático, dever-se-ia manter o mesmo horizonte teórico (princípio geral), e desenvolver os métodos para sua implementação, ou seja, aprimorar os meios para atingir o objetivo da reabilitação, ainda que se saiba de sua falibilidade estrutural.

Neste mesmo sentido, o argentino Jorge Perano (2009: 678) credita ao discurso da prevenção especial positiva (ressocialização) a capacidade de limitar a fundamentação da teoria especial negativa (neutralização), ou ainda da teoria geral positiva, as quais serviriam para legitimar um encarceramento indefinido e ilimitado.

Baratta (1990: 2) relata um encontro de criminalistas alemães, ocorrido na década de 80 do século passado em Frankfurt, no qual um dos mais renomados pesquisadores da Alemanha reconhecia o fracasso das ações de ressocialização por meio da prisão. Porém, ao mesmo tempo, sustentava que era preciso manter a ideia da ressocialização para não dar abertura àqueles que advogavam as teorias da retribuição e da neutralização.

Tais discursos (que podem ser ilustrados pela máxima "ruim com a reabilitação, pior sem ela") ainda que pareçam dirigir a punição para um fim mais "humano"- evitando assim os excessos retributivos- reacendem uma ideia que vem sendo questionada desde os anos 70 : a de que com uma conjuntura melhor a prisão teria sim a capacidade de reabilitar pessoas. E realimentam a ilusão de que a punição, especificamente a prisão, é o caminho a ser seguido para alcançar a integração social.

No atual momento histórico, a pena de prisão se apresenta de uma forma mais descarnada, sem floreios ou falsas ilusões. Este fato talvez possa contribuir para que a sociedade

\footnotetext{
16Em entrevista à Revista Consciência http://www.comciencia.br/comciencia/handler.php?section=8\&tipo=entrevista\&edicao=35, acesso 23/04/2009.
} 
reavalie os usos e a necessidade da prisão. Sustentar a perspectiva da reabilitação culmina na legitimação da aplicação da pena de prisão sob o discurso hipócrita de que a punição é aplicada visando o bem do apenado. Desta forma, a sociedade pode manter a consciência tranquila, sem questionar sua responsabilidade pela segregação social de certos indivíduos ou pelo mal que lhes é imposto.

Da mesma forma, a crise do paradigma da reabilitação não representa, necessariamente, um retrocesso no caminho da humanização das penas, porque o discurso da reabilitação, especificamente no que se refere aos estabelecimentos prisionais brasileiros, não levou a uma efetiva humanização da execução penal.

Uma das hipóteses levantada por Álvaro Pires ${ }^{17}$ é que o sistema de ideias conformado pelas funções da pena (retribuição, da dissuasão e da reabilitação) tornou-se um obstáculo cognitivo à evolução do sistema de direito criminal.

Não vamos lamentar o fim desta forma de governar servidões e liberdades, porque outra forma trará novas servidões e liberdades: "Não se deve se perguntar qual o regime mais duro, ou o mais tolerável, pois é em cada um deles que se enfrentam as liberações e sujeições" (Deleuze, 1992: 220).

A crença de que não podemos prescindir da punição está arraigada no coração da sociedade. Talvez, antes de pensarmos em abolir o castigo ou em formas mais amenas de realizá-lo, devêssemos lutar por mudanças no próprio processo punitivo, fazer com que as práticas divisoras, hierárquicas e seletivas se tornem mais dialógicas e democráticas. Então, quem sabe possamos imaginar a reação social ao fato criminoso como produtora da solidariedade social.

\subsection{Reintegração social e as "ideologias res"}

O conceito "reintegração social" é central nessa pesquisa, e determinou tanto algumas reflexões teóricas quanto escolhas metodológicas. De início, tinha esperança de ouvir dos meus entrevistados o que eles entendiam de reintegração social, com o objetivo de, a partir

17 Apresentada em Conferência no Seminário Internacional "Perspectivas da justiça criminal brasileira". São Paulo, setembro, 2009. 
dessas respostas, formular um conceito. Contudo, durante a realização do campo da pesquisa, percebi que o significado de "reintegração social" que esperava ouvir dos meus informantes só tinha sentido dentro do meu referencial teórico, já que na prática o termo estava associado a outros significados.

O termo reintegração social é utilizado por parte da imprensa, dos gestores públicos e da academia, como sinônimo de ressocialização, reeducação, reabilitação, recuperação, etc. Porém, em um sentido estrito, e do qual parte essa pesquisa, ele é empregado justamente para fazer frente às chamadas ideologias "res", segundo as quais o indivíduo é objeto de intervenção penal; cabendo ao sistema penitenciário modificar o modo de ser do apenado, e a este readequar seus valores e atitudes como condição para que seja aceito pela sociedade:

“ 'Tratamento' e 'ressocialização' pressupõem uma postura passiva do detento e ativa das instituições: são heranças anacrônicas da velha criminologia positivista que tinha o condenado como um indivíduo anormal e inferior que precisava ser (re)adaptado à sociedade, considerando acriticamente esta como 'boa' e aquele como 'mau'".

(Baratta, 1990: 3)

Ao menos três pressupostos da reintegração social a diferencia das ideologias "res":

1. o preso é visto como um individuo "normal", que se diferencia dos demais somente pelo fato de estar preso;

2. o individuo é sujeito da Execução Penal, e portanto, deve poder manifestar sua vontade e autonomia nas atividades desenvolvidas em âmbito prisional;

3. a sociedade é corresponsável pela "reintegração social”, pela retomada do diálogo com aqueles que estão privados de liberdade.

As estratégias ditas de reintegração social não devem ter a pretensão de promover no interno qualquer tipo de "readequação ética", ou, em termos gerais, de "readequação" de conduta. Não devem ter a pretensão de "conscientizá-lo" sobre seus "erros" no passado (Sá, 2008: 14).

Ainda que os pensadores e gestores queiram diferenciar conceitualmente a reintegração social das antigas ideologias "res", esse movimento é repleto de ambiguidades e atos falhos. 
A velha ideologia do tratamento impregnou de tal forma nossos modos de pensar que, ainda quando se parece estar se distanciando dela, ela reaparece na forma de uma expressão, de uma palavra ou de construção do discurso. E, certamente, a presença de elementos relacionados à ideologia de tratamento nos nossos discursos aponta que, de alguma forma, ainda não nos libertamos dela.

De acordo com Michel Foucault em As palavras e as coisas (2002), a linguagem é o lugar onde a verdade se manifesta e se enuncia, mas não no sentido de que existe uma verdade a ser desvelada, esperando que a traduzam em palavras; mas, ao contrário, a elaboração do discurso é constitutiva da realidade. A linguagem não só nomeia as coisas, mas lhes atribui significado.

A verdade é construída à medida que se interpreta a realidade e se escolhem os enunciados e a linguagem adequados para tanto. Nesse sentido, não há linguagem neutra, porque a interpretação sempre pressupõe uma escolha. Segundo Foucault (1996: 20), na vontade de se proferir um discurso verdadeiro, o que está em jogo é desejo e poder ${ }^{18}$.

As chamadas práticas discursivas têm a função de determinar o que e como pode ser dito, estabelecendo as maneiras e possibilidades de compreender o mundo. A hegemonia do saber penal na resolução dos conflitos tem como consequência a construção de uma verdade acerca da delinquência e a naturalização da solução punitiva, de modo a limitar qualquer outra forma legítima de abordar e resolver o problema ${ }^{19}$.

Autores como Becker (1971: 26) e Hulsman (2004:52) alertam para a necessidade da modificação da linguagem ao se referir aos acontecimentos penais como uma forma de lidar de forma diferente com esses eventos.

${ }_{18}$ Sendo que o discurso não é um meio para chegar-se ao poder, mas o exercício do poder em si mesmo.

${ }^{19}$ Daí também a crítica de Foucault à funcionalidade do discurso criminológico, na medida em que é "inteiramente utilitário" e cumpre a função de justificar a necessidade das medidas punitivas (Foucault, Sobre a Prisão, in 2004:138). 
A diminuição do espaço que a prisão ocupa em nossas sociedades requer uma espécie de conversão coletiva. Para Folter (2008:187), essa conversão requer, antes de mais nada, a abolição dos conceitos tradicionais e da "gramática" do sistema penal.

Da mesma forma, é necessário atentar para o uso de alguns termos em relação ao preso e a pena, e perceber que realidade se está criando. Ainda hoje se faz uso da expressão "tratamento penal", a qual transmite (in)diretamente a ideia de que o preso possui alguma doença, e a execução penal agiria no sentido de sua cura.

Outra realidade é criada por uma multiplicidade de discursos- de técnicos, agentes penitenciários, presos, poder público etc. - ao se referirem ao preso enquanto reeducando. Convencionou-se chamá-los de reeducandos - inclusive, ao que parece, é o "politicamente correto"- como forma de não reforçar o estigma que outras palavras (como delinquente) carregam.

Porém, essa é uma escolha que reafirma a constante necessidade de readequação do preso e que o fixa nessa condição. Nomear a pessoa privada de liberdade a partir de sua condição intransponível, ou seja, preso, deixando de lado os eufemismos, talvez possa contribuir para o não mascaramento da violência do sistema penal.

Logo, é importante perceber os usos da palavra, porque mais do que representar uma ideia, elas constituem uma verdade. Alguns deslizes na linguagem podem ser observados também quando se fala de reintegração social. O primeiro e mais comum, é o uso da fórmula "reintegração social do preso". Ao utilizar essa forma, mantém-se a ideia de que cabe ao preso readequar-se à sociedade, quando a via é "de mão dupla". A reintegração é entre o preso e a sociedade. Conforme ilustram Rocha e Salvério:

"Houve dessa forma, uma evolução de uma perspectiva finalista, em que o desiderato da reinserção era a retomada por parte do delinquente da conformidade jurídico-penal, para uma perspectiva abrangente, que implica no mesmo processo de socialização o delinquente, o Estado e toda a sociedade"

(Rocha e Salvério, 2005: 246) 
Mas mesmo construções teóricas como esta, que parece ser fiel ao conceito estrito de reintegração, vem acompanhadas de ambiguidades, pois logo em seguida no texto os mesmos autores fazem uso de uma expressão bem típica da ideologia reabilitadora:

"A ressocialização- que supõe um trabalho de remodelação do indivíduo associal- e a reinserção- que lhe assegura um lugar na sociedade"

(Rocha e Salvério, 2005: 251)

Depois de expor alguns usos comuns ao termo reintegração social, cabe agora delinear qual sentido que o ele assume nesta pesquisa.

\subsection{Significando a reintegração social}

"Ressaltamos a necessidade da opção pela abertura da prisão à sociedade e, reciprocamente, da sociedade à prisão. Um dos elementos mais negativos das instituições carcerárias, de fato, é o isolamento do microcosmo prisional do macrocosmo social, simbolizado pelos muros e grades. Até que não sejam derrubados, pelo menos simbolicamente, as chances de "ressocialização" do sentenciado continuarão diminutas. Não se pode segregar pessoas e, ao mesmo tempo, pretender a sua reintegração. Todavia, a questão é mais ampla e se relaciona com a concepção de 'reintegração social"".

(Baratta, 1990: 3)

Dentre os muitos usos do termo reintegração social, escolhi a abordagem de Alessandro Baratta como norteadora desta pesquisa, especialmente a exposta no artigo "Ressocialização ou Controle Social: Uma abordagem crítica da 'reintegração social' do sentenciado" (Baratta,1990).

Um dos sentidos da reintegração social- que considero de suma importância- diz respeito à volta do egresso à sociedade, de forma a lhe possibilitar o exercício de seus direitos individuais, políticos e sociais. Porém, como me interessa estudar a dinâmica de integração a partir do espaço prisional e não após a saída do preso, essa perspectiva da reintegração não se mostra tão profícua aos fins da presente pesquisa.

Baratta (1990:9) compreende a reintegração social a partir de dois núcleos: o primeiro ligado às oportunidades que serão dadas aos presos depois de cumprir a pena (benefícios e oportunidades de trabalho); o outro, relacionado a estratégias e práticas de descarcerização, 
com a criação de condições culturais e políticas que permitam à sociedade "livrar-se da necessidade da prisão".

Para os fins desta pesquisa, escolhi trabalhar apenas com o segundo núcleo da reintegração social; tal abordagem norteou também o recorte no universo de projetos de reintegração analisados na pesquisa. Certamente, há inúmeros projetos, no molde dos patronatos, que pensam a integração a partir da saída do indivíduo do espaço prisional; porém, o universo desta pesquisa ficará restrito apenas às ações da sociedade civil desenvolvidas dentro do espaço prisional.

\subsubsection{Reintegração apesar da prisão}

A estratégia de ação na prisão de Baratta em muito se assemelha à de Thomas Mathiesen ${ }^{20}$ (1989). Ele defende um objetivo reformador a curto e médio prazo (minorar o sofrimento dos presos), sem perder de vista uma mudança profunda a longo prazo. Para Baratta (1990: 2), a estratégia reformista só tem sentido se pensada em conjunto com o objetivo “libertador”. Neste sentido, “o objetivo imediato não é apenas uma prisão 'melhor' mas também e sobretudo menos cárcere". Segundo o autor:

"Sob o prisma da integração social e ponto de vista do criminoso, a melhor prisão é, sem dúvida, a que não existe.(...) Nenhuma prisão é boa e útil o suficiente para essa finalidade, mas existem algumas piores do que outras. Estou me referindo a um trabalho de diferenciação valorativa que parece importante para individualizar políticas de reformas que tornem menos prejudiciais essas instituições à vida futura do sentenciado"

(Baratta, 1990: 3)

A longo prazo, a melhora das condições do cárcere e a entrada da sociedade civil em seus espaços podem levar à diminuição qualitativa e quantitativa do encarceramento. Os efeitos da prisionização podem ser minimizados com a relativa abertura dos muros da prisão para a sociedade e fortalecimento social e psíquico dos apenados.

A privação de liberdade não converge para a construção de um sujeito mais autônomo e integrado. Se não temos condições, no momento, de prescindir das prisões, também não podemos reforçar a falácia representada pelas ideologias de reeducação e ressocialização.

\footnotetext{
${ }^{20}$ Apresentada no Capítulo 1
} 
Uma nova perspectiva de trabalho deve ser pensada, desvinculada da lógica de prêmio e castigo, não a partir do cárcere, mas apesar dele.

A partir de uma perspectiva crítica, uma das condições de qualquer proposta de reintegração social é que ela seja vista como um direito do preso e seja de participação voluntária.

Para Borja Mapelli (apud Perano, 2009: 678), a reinserção crítica pode servir de instrumento para o desenvolvimento de uma estratégia penitenciária abolicionista, e evitar a manipulação tecnocrática. Para tanto, a participação em qualquer atividade na penitenciária deve ser voluntária e específica para cada detento.

A reintegração constitui uma "via de mão dupla", a abertura de um processo de comunicação a partir do qual os presos possam se reconhecer na sociedade e esta possa se reconhecer na prisão, sendo que ambos têm responsabilidade por essa reaproximação (Baratta, 1990: 3). Louk Huslman (1985) fala da necessidade de pessoas de diferentes posições sociais e de diversas formações se aproximarem realmente e fisicamente do cárcere.

De tal sorte, que a participação ativa da sociedade civil é uma das condições para a prática da reintegração social. Conforme, analisarei nos capítulos seguintes, os grupos críticos em relação à prisão buscam alternativas a longo prazo, enquanto propõem e realizam programas de intervenção, os quais podem ser sintetizados pelo lema "levar a rua à prisão já que não podemos levar a prisão à rua" ${ }^{21}$ (Molina, 1997:164).

Para Sá (2007: 163), a reintegração pressupõe uma mudança significativa de enfoque do chamado "tratamento penitenciário", que deixaria de centrar-se na pessoa do reeducando, para fazê-lo nas relações sociais das quais ele faz parte. É a mudança de uma visão individual para uma visão sistêmica. Entre os atores da reintegração social, não existem "pessoas-sujeitos" e "pessoas-objetos", apenas sujeitos relacionais. O trabalho de reintegração social pressupõe a ativação da rede social, ou seja, do conjunto de relações interpessoais do individuo (família, amigos, vizinhos, colegas).

\footnotetext{
${ }^{21}$ Tradução livre. No original "llevar a la calle a la prisión ya que no podemos llevar la prisión a la calle”.
} 
Parte da literatura atribui ao sucesso da reintegração social o desenvolvimento de uma sociedade menos criminógena e a formação de indivíduos mais resistentes ao sistema de controle:

"O objetivo da ressocialização foi substituído a partir dos anos oitenta pelo da reintegração social, com criação de condições para que os indivíduos se mantenham na sociedade sem novas confrontações com a norma e o sistema penal". 22

(Snacken, 2002: 134)

No conceito de reintegração trazido pela criminóloga belga Sonja Snacken, o objetivo de evitar "novas confrontações" 23 talvez seja um pouco problemático. Primeiro porque estamos todos nos confrontando o tempo todo com a norma e com o sistema penal. E, depois, porque o confronto, o embate, ainda mais em se tratando de egressos do sistema penal, é de alguma forma inevitável (visto que eles continuam sendo alvo preferencial do sistema de controle). Talvez fosse mais apropriado e realístico falarmos em alcançar algum grau de fortalecimento desses indivíduos perante o sistema de justiça, assim como um mínimo de abertura e flexibilidade da sociedade em relação às ações desviantes de pessoas que são normalmente criminalizadas.

\subsubsection{A prisão e o mundão: ruptura e continuidade}

Para fins analíticos, é necessário que criemos categorias a partir do nosso objeto, porém elas não dão conta de explicar a realidade- sempre multifacetada e complexa. Um difícil exercício metodológico está em recusar uma visão reducionista da realidade, uma construção do mundo a partir de categorias binárias.

Para grande parte da literatura, principalmente da década de 70, a prisão era concebida como um espaço independente e isolado da sociedade como um todo. Um dos responsáveis por consolidar essa posição foi Erving Goffman em sua obra Asylums, publicada

\footnotetext{
${ }^{22}$ Tradução livre. No original "L'objectif de resocialisation se trouve remplacé à partir dès années 1980 par la 'réintégration sociale', c'est-à-dire la création de conditions pour que les libérés puissent se maintenir dans la société sans nouvelles confrontations avec les normes er le système pénal".

${ }^{23}$ Construção parecida à essa é usada na área da Infância e Juventude para se referir ao adolescente autor de ato infracional: "adolescente em conflito com a lei".
} 
originalmente em 1961, na qual o autor canadense cunhou o conceito de instituição total ${ }^{24}$ caracterizada essencialmente por seu fechamento em relação ao exterior.

A cultura prisional é comumente vista como completamente distinta da "cultura da sociedade", seja porque lhe faltam valores e atributos que parecem estar presentes na sociedade, seja porque aparece como alternativa ou opositora à cultura do "mundão" 25 .

Jock Young (2002: 128) retrata duas posições no tocante à relação da cultura negra com a cultura dominante. Uma que retrata a "subclasse" como carente de cultura, como nãosocializada na cultura mais ampla, e outra que a vê como cultura alternativa à dominante. Para a primeira, a subclasse urbana se forma a partir da exclusão econômica e espacial, a qual dá origem à desorganização social, alienação cultural, diferenças de estilos, valores e aspirações entre a subclasse e cultura dominante. Já a segunda posição vê a cultura negra como alternativa: os de esquerda a veem como uma cultura de luta, de reação; enquanto os de direita a veem como indisciplinada, intransigente, inassimilável.

O criminólogo inglês chama atenção para o fato de que nenhuma das teorias caracteriza a cultura negra como incorporada à cultura dominante ${ }^{26}$. Tal interpretação pode ser aplicada analogicamente à relação entre cultura prisional e cultura de fora da prisão. Por vezes, a cultura prisional é vista a partir das carências em relação à cultura do mundão. Outras vezes, é vista como alternativa, opositora, mas poucas vezes como incorporada à cultura da sociedade em geral.

Todavia, como bem demonstram recentes pesquisas nessa área ${ }^{27}$, a prisão está em constante relação com a sociedade que a rodeia. Logo, é necessária a releitura da ideia de

\footnotetext{
24 A própria aplicação do conceito de instituição total à realidade brasileira é questionável devido às condições específicas dos nossos cárceres (superlotação, falta de controle do Estado, corrup ção).

${ }^{25}$ Mundão é um termo utilizado pelos presos para designar a sociedade livre, o mundo além da prisão. Como em um verso da letra Vida Loka dos Racionais Mcs: "Tudo, tudo, tudo vai, tudo é fase irmão Logo mais vamo arrebentar no mundão"

${ }^{26}$ Young evoca para o estudo de Carl Nightingale (On the edge) sobre o gueto negro na Filadélfia, no qual o autor busca compreender o grau de inclusão do negro na cultura americana.

${ }^{27}$ Nesse sentido ver as produções de Gabriel Feltran (UFSCAR); Vera da Silva Telles e seus orientandos Rafael Godoi e Daniel Hirata (USP) acerca das redes e códigos presentes em algumas comunidades e suas relações com a prisão, assim como as dissertações de Adalton Marques (USP) e Karina Biondi (UFSCAR) acerca do PCC.
} 
prisão enquanto instituição total, com uma cultura completamente distinta e independente do "mundão".

Nesse sentido, é preciso relativizar a noção de totalidade absoluta da prisão, de que dentro e fora constituem dois mundos incomunicáveis, pois a relação entre esses dois "mundos" pode ser vista muito mais como continuidade do que como ruptura. Muitas vezes, a entrada na prisão representa uma continuidade nas relações estabelecidas fora do cárcere, ou mesmo possibilita a integração do preso em uma rede, formada pela comunidade, família e por pessoas de fora do espaço prisional, incluindo aqui os membros da facção criminosa.

Segundo Maria Palma Wolff (2009: 5), é preciso um trabalho no sentido de desnaturalizar a linha divisória entre prisão e sociedade, uma vez que elas compartilham dos mesmos processos sociais.

Por isso, quando me refiro à reintegração nesta pesquisa, não pressuponho que as pessoas prisionizadas não estejam integradas à sociedade de fora da prisão, ou que a cultura da prisão seja independente da cultura da sociedade; ao contrário, reconheço que existem relações, trocas materiais e simbólicas. Essas trocas, porém, não incluem alguns dos bens materiais e culturais produzidos pela sociedade.

Nesse sentido, não só os presos e egressos não têm acesso aos bens produzidos pela sociedade e ao mercado de trabalho, mas grande parcela da sociedade também não o tem. Logo, a desintegração entre sociedade e a população prisional ocorre de forma análoga mesmo dentro da dita sociedade livre:

"Se verificarmos a população carcerária, sua composição demográfica, veremos que a marginalização é, para a maior parte dos presos, oriunda de um processo secundário de marginalização que intervém em um processo primário. É fato comprovado que a maior parte dos presos procede de grupos sociais já marginalizados, excluídos da sociedade ativa por causa dos mecanismos de mercado que regulam o mundo do trabalho."

(Baratta, 1990: 3)

Logo, nesta pesquisa, o termo reintegração social assume o sentido de aproximação de universos distintos: do mundo prisional (e suas redes na sociedade) com um outro mundo, 
representado pela "sociedade mais ampla", que só indiretamente se envolve com as questões do cárcere. Daí não se conclui que a prisão e os presos não estejam integrados na sociedade em outros níveis, porém eles continuam excluídos em certos espaços sociais (tal como do mercado, da academia, da mídia).

Apesar das redes existentes entre cárcere-comunidade, a segregação representada pelos muros da prisão e pelo estigma que ela carrega faz com que a vida na prisão seja essencialmente diferente da vida fora dela. Para minimizar este contraste, o anteprojeto de lei penitenciária da Bélgica, apresentado pela criminóloga belga Sonja Snacken (2002: 136), propõe que a vida na prisão deveria ser tão parecida quanto possível à vida exterior, ou seja, somente aceitar as restrições inerentes à privação da liberdade.

Quanto mais a prisão difere da vida livre, mais difícil a adaptação após a vida prisional. A reinserção de uma pessoa no meio social deveria preocupar a sociedade, uma vez que todos os presos- desde que sobrevivam às intempéries da vida prisional - sairão um diaespecialmente no Brasil, onde não se prevê oficialmente a pena de morte ou prisão perpétua.

A fala de um preso $^{28} \mathrm{em}$ uma reunião do GDUCC ilustra esse contraste: "Pra sair da cadeia tem que desligar o "piloto automático" e analisar o que fazer com as muitas portas que o mundão oferece”.

\subsection{Bases teóricas para um trabalho de reintegração social}

"E, para conhecer a materialidade e o funcionamento das estruturas que se quer mudar, é preciso desenvolver uma prática"

(Hulsman, 1993: 37)

Cinco são os autores que escolhemos ${ }^{29}$ para compor o arcabouço teórico de uma proposta prática de reintegração social: o penalista argentino Eugenio Raul Zaffaroni, que propõe a clínica da vulnerabilidade para diminuir o nível de vulnerabilidade do indivíduo frente ao sistema de justiça criminal; o criminólogo basco Antonio Beristain, que ressalta a necessidade do reencantamento da criminologia e da maior proximidade das pessoas; o

${ }^{28}$ Caderno de Campo projeto piloto GDUCC- Adriano Marrey, maio de 2010.

${ }^{29}$ Ainda que a presente tese esteja escrita em primeira pessoa, em alguns momentos optei pelo uso da segunda pessoa do plural. O "nós" aqui engloba as reflexões propostas pelo orientador desta tese e desenvolvidas em conjunto com seus orientandos em torno do GDUCC. 
marxista italiano Alessandro Baratta, responsável por cunhar o termo reintegração social; o psicólogo brasileiro Alvino Augusto de Sá, que tem se destacado na discussão clínica da Criminologia no Brasil e tomado a frente nos debates de propostas para inovações na Execução Penal; e ainda, o sociólogo sul-africano Stanley Cohen, que expõe os limites e riscos da proposta de reintegração social.

\subsubsection{Clínica da vulnerabilidade: a proposta de Zaffaroni}

Visando integrar os pressupostos críticos com uma atuação clínica, Eugênio Raul Zaffaroni propôs a ideia de "clínica da vulnerabilidade" 30 enquanto "um saber que permita ajudar as pessoas criminalizadas a reduzir seus níveis de vulnerabilidade" (1998: 26) ou "uma técnica tendente a ensinar ao homem a não oferecer a face à bofetada do sistema penal" (1990: 64).

A criminologia crítica central tende a negar ou descartar a criminologia voltada para o indivíduo, que se ocupa do diagnóstico e prognóstico criminal. Contudo, essa resistência somente só teria sentido em relação a uma clínica etiológica que se esgota no plano biopsicológico. A partir da constatação de que são selecionados pelo sistema penal não só os socialmente vulneráveis, mas os psiquicamente vulneráveis, mostra-se plenamente justificável a existência de uma criminologia de abordagem sócio-psico-biológica centrada no estudo da vulnerabilidade individual perante o sistema de controle (Zaffaroni, 1998:24).

Zaffaroni propõe a substituição de uma etiologia da conduta criminal por uma "etiologia da vulnerabilidade"; ou seja, ao invés da criminologia se debruçar sobre a biografia do indivíduo, tentando explicar a formação de sua identidade delinquente, ela compreenderia a história de fragilização daquela pessoa perante o sistema punitivo com o objetivo de revertê-la, tentando evitar assim a criminalização secundária e quebrar a "profecia-que-seauto-realiza".

O caminho para o fortalecimento do indivíduo dar-se-ia por meio de um diálogo aberto e autêntico, de forma a tornar as escolhas cada vez mais conscientes:

\footnotetext{
${ }^{30}$ Zaffaroni escolhe mudar a denominação criminologia clínica para clínica da vulnerabilidade para justamente romper com a associação dessa criminologia com aquela outra formulada pela escola positivista italiana.
} 
"A clínica da vulnerabilidade não é uma colocação ao nível de superioridade ética, de superioridade moral frente aos criminosos contra a propriedade. Simplesmente dizer: desse jeito não. Se você escolhe o trabalho de freguês da cadeia é uma escolha; mas mostrar, tornar consciente essa escolha, é uma comunicação existencial de perceber que, no fundo dessa escolha, acha-se um erro, que conduz à deterioração e à destruição da pessoa e, na nossa realidade, à morte"

\section{(Zaffaroni, 1990: 59)}

É essa vulnerabilidade, ocasionada tanto por fatores sociais quanto individuais, que leva o indivíduo a ser selecionado pelo sistema de controle, que é estruturalmente seletivo e reprodutor das relações sociais. Nas precisas palavras de Zaffaroni:

"Os órgãos do sistema penal selecionam de acordo com estereótipos, atribuindo-lhes e exigindo-lhes [dos presos] esses comportamentos, tratando-os como se comportassem dessa maneira, olhando-os, e instigando todos a olhá-los do mesmo modo, até que se obtém, finalmente, a resposta adequada ao papel assinalado"

$$
\text { (Zaffaroni, 1991:133) }
$$

Em oposição ao conceito de vulnerabilidade, está o conceito de sofisticação elaborado por Turk $^{31}$. Para o sociólogo americano, a sofisticação é a capacidade de conhecer a conduta dos atores do sistema de controle e de manipular a própria conduta a partir desse conhecimento, de forma a dificultar a criminalização.

"A sofisticação dos sujeitos significa que estes serão mais cuidadosos em avaliar a força ou fraqueza de sua oposição em relação às autoridades e que consequentemente, estarão com maior capacidade para evitar a guerra aberta com elas sem fazer concessões significativas (...) O conflito é mais provável quanto menos sofisticados os sujeitos".

(Turk apud Castro, 1983:116)

Quanto mais estigmatizado o indivíduo, menos liberdade de manipulação de sua conduta ele tem, e, consequentemente, menos sofisticado ele será perante o sistema de controle, com maior chance de ser criminalizado.

\subsubsection{A mística de Antonio Beristain}

Antonio Beristain, falecido no final de 2009, fundador e diretor do Instituto Vasco de Criminologia, também inspirou a prática da reintegração social. Sua proposta mística de reencantamento da criminologia passa pelo reencontro dos seres humanos, a partir de um

\footnotetext{
${ }^{31}$ Turk, A (1969). Criminality and Legal Order, USA, Rand Mc Nally Sociology Series.
} 
movimento de abertura que possa proporcionar uma aproximação entre os sujeitos desse diálogo.

A proposta de reencantamento de Beristain nasce a partir do diagnóstico de Weber de “desencantamento do mundo", de perda de sentido, desmagificação ${ }^{32}$. Na leitura de Pierucci (2003), o termo utilizado por Weber tem dois sentidos: o primeiro remete ao desencantamento do mundo pela religião, e o segundo, pela ciência. $\mathrm{O}$ modelo religioso se afastaria da magia ao determinar o modus vivendi das pessoas, reformulando a visão e a postura em relação ao mundo. Já a ciência, apesar de seu alto grau de desenvolvimento, falha ao tentar dar sentido ao mundo, uma vez que ela aborda o mundo em partes, buscando dar causas aos fenômenos, mas não respostas para o sentido do mundo como um todo.

Beristain (1993) descreve a transição da cultura mágica para a cultura mística, e depois para a cultura racional- na qual permanecemos ancorados a alguns séculos. Para ele, perante o desencantamento do mundo, seria preciso recuperar alguma dimensão transcendental, valorativa, mística da vida. Essa nova forma, ademais de formulação teórica, é antes de tudo experimentável, antes de ser ideia é experiencia-realidade pessoal.

O autor basco trabalha com três categorias chaves: desencantamento, proximidade e reencantamento. Ele diagnostica um desencantamento nos criminólogos decorrente da violação dos direitos humanos e da finitude de nossas ferramentas (Beristain, 2007: 223). O conceito chave para a superação do desencantamento é a proximidade, manifesta por meio de experiências religiosas e místicas (Reiss ${ }^{33}$ apud Beristain, 2007: 244). A partir da proximidade, a desmoralização, a alienação e a apatia características do mundo desencantado podem dar lugar ao reencantamento (Beristain, 1993: 343).

Esse processo pressupõe a ampliação das reflexões sobre o sistema de justiça criminal em um contexto social e cultural mais extenso, com um maior envolvimento da sociedade nas questões de política criminal.

\footnotetext{
32 No raciocino weberiano magia é "a coerção do sagrado, compulsão do divino, conjuração dos espíritos" (Pierucci, 2003: 70).

33 REISS, A.J. Perplexing questions in the understanding and control of violent behavior" An, Int. Crim. 1990: 24.
} 
Beristain (1998: 219) propõe ainda a figura do "advogado criminólogo", que seria responsável por acompanhar a execução da pena e defender o preso no que for necessário. Esse profissional, além de se informado das condições em que seu cliente está cumprindo a pena, estaria incumbido de incentivar a reparação do dano causado à vítima, de assistir seu cliente após sua saída da penitenciaria, assim como de sugerir medidas pertinentes a ele e seus familiares.

De uma perspectiva otimista, ele atesta o surgimento de uma nova epistemologia do direito penal, mais solidário, fraternal, generoso e criador. E permite sonhar com prisões diferentes, que tenham espaço para o desenvolvimento holístico do ser humano:

"Nos cárceres, oxalá haja escolas para ensinar a ler e escrever, mas convém que haja mais locais para aprender e exercitar em paz as técnicas de relaxamento, ioga, de meditação transcendental e as práticas correspondentes para poder auscultar, conhecer e contemplar sem tanto alvoroço passional"

(Beristain, 2000: 60)

O desejo manifestado por Beristain parece ter ganhado vida em alguns projetos de yoga e meditação realizados nas prisões no Brasil e no exterior, e de uma maneira mais radical na reforma da prisão de Tihar na Índia, iniciada em 1993. Uma série de ações foram adotadas com vista a transformar um dos maiores complexos prisionais do mundo -notadamente conhecido por seu alto grau de corrupção e violência - em um lugar melhor.

Dentre as principais medidas adotadas em Tihar estavam: abertura do cárcere para a comunidade e da comunidade para o cárcere por meio do trabalho voluntário; implementação de um sistema de gestão participativa; construção de um "sistema de ventilação" das queixas dos presos; e aprimoramento da comunicação entre eles, e deles com a direção. Mas, sem dúvida, a medida mais ousada foi a disseminação da prática da meditação vipassana na prisão, que teve reflexos nos presos e no ambiente prisional $^{34}$.

\footnotetext{
34 Para uma abordagem aprofundada ver BRAGA, Ana Gabriela Mendes. Meditação no cárcere: libertando-se da prisão interior. Revista Brasileira de Ciências Criminais, v.75, 2009.
} 


\subsubsection{Estratégias de reintegração social: Alessandro Baratta}

O criminólogo italiano Alessandro Baratta sistematizou algumas estratégias de reintegração $\operatorname{social}^{\mathbf{3 5}}$. Ao transformar ideias abstratas em indicações pontuais e concretas, Baratta contribuiu para que a materialização de sua concepção da reintegração social, a partir:

"de uma mudança radical e humanista e não de um reformismo tecnocrático cuja finalidade e funções são as de legitimar através de quaisquer melhoras o conjunto do sistema prisional"

(Baratta, 1990: 3)

Ele sugere uma prática alternativa a partir de um programa de dez pontos ${ }^{36}$, prática que se quer "coerente do princípio da independência funcional da pena/disciplina e reintegração" (Baratta, 1990: 4).

Dentre os dez pontos, destacamos seis que se aplicam diretamente a um trabalho na execução penal, nos moldes que se tem pensado na presente pesquisa. São eles: a presunção de normalidade do preso, a construção de relações simétricas sob uma perspectiva de igualdade; a participação ativa do sentenciado na escolha e decisão sobre as atividades que irá desempenhar; a preocupação com os funcionários da prisão; a presença de trabalhos voluntários na dinâmica prisional; e, ainda, a destecnização da questão prisional (Baratta, 1990: 7-9).

\section{Presunção de normalidade do preso}

Essa é a premissa básica de qualquer trabalho de reintegração social: a única coisa que difere o preso das pessoas não presas é a própria prisão. A criminalização de determinada pessoa deflagra uma vulnerabilidade psicossocial perante o sistema punitivo, e a própria vivência prisional agrava esse quadro de vulnerabilidade (processo de prisionização), contribuindo para a criminalização secundária daquele indivíduo e para o seu consequente retorno ao sistema (reincidência).

\footnotetext{
35 Tais estratégias foram trabalhadas no artigo BRAGA, Ana Gabriela e BRETAN, Maria Emília. Teoria e prática da reintegração social: o relato de um trabalho crítico no âmbito da execução penal In: Criminologia Aplicada aos Problemas da Atualidade. São Paulo: Atlas, 2008.

36 Cabe ressaltar que as indicações de Baratta foram tomadas como norte na formulação da metodologia de trabalho do GDUCC.
} 


\section{Construção de relações simétricas}

Dentro de um trabalho de reintegração social que se pretenda distante de uma proposta de readequação ética ou qualquer discurso moralizante, a construção de relações simétricas aparece como um grande desafio. Despir-se da intenção de querer convencer o outro da sua própria verdade já é uma tarefa difícil no dia-a-dia; tarefa que, na penitenciária, se mostra ainda mais difícil, principalmente pelo fato de o Direito Penal ser carregado de fortes concepções ético-religiosas, pautado por conceitos de bem e mal, onde o crime está atrelado à culpa e a pena à expiação.

\section{Participação ativa do sentenciado}

Outro pressuposto da reintegração social é que, enquanto maior interessado e sujeito da execução penal, o preso deve se manifestar e ser propositivo no tocante às atividades a serem realizadas durante o cumprimento da pena.

\section{Preocupação com os funcionários da prisão}

A preocupação com os funcionários da prisão se desdobra em duas atuações: uma delas é aproximar e envolver o pessoal do presídio no trabalho que é realizado com os presos, não só por uma demonstração de respeito para com a "casa", mas também com vistas a harmonizar as atividades lá realizadas.

\section{Realização de trabalhos voluntários na dinâmica prisional}

Entre as diversas propostas práticas de Alessandro Baratta para a reintegração social, destaca-se a importância da presença de membros da comunidade na dinâmica prisional, principalmente por meio de realização do voluntariado, que teria a função de fiscalizar a dinâmica prisional e possibilitar outras formas de relações no cárcere.

\section{VI. “Destecnização" da questão prisional}

Apesar de ser de suma importância, a presença de técnicos (psicólogos, assistentes sociais, psiquiatras) na prisão, na perspectiva de Baratta, a execução penal deve ser "destecnificada", "despsicologizada" e "despsiquiatrizada", de forma tal que cada vez mais pessoas se responsabilizem e se comprometam com a questão penitenciária. A temática da prisão tem que ser apropriada por outros saberes e seu debate legitimado em outros âmbitos. 


\subsubsection{Criminologia Clínica e Execução penal no Brasil: a proposta inovadora de}

\section{Alvino Augusto de Sá}

Alvino Augusto de Sá, da Universidade de São Paulo, tem sido pioneiro na discussão brasileira de propostas de intervenção no cárcere. Criminólogo com formação em Psicologia Clínica, orientador da presente pesquisa, vem desenvolvendo há alguns anos um olhar clínico atento aos questionamentos propostos pela criminologia crítica.

Em recente tese de livre docência (Sá, 2011), Sá discute três modelos de Criminologia Clínica: o medico- psicológico, o psicossocial e o de inclusão social, denominados modelo de primeira, segunda e terceira geração, respectivamente.

De acordo com o modelo de terceira geração defendido pelo autor, a Criminologia (e mesmo o Direito Criminal) deve perseguir a meta da inclusão social. Nesse sentido, a inclusão é concebida essa como um "processo ativo, dinâmico, de autodescoberta, autovalorização dentro do contexto social” (Sá, 2011: 305).

A reintegração social configura como estratégia para alcançar essa meta. Para Sá (2011: 306), a reintegração social se opõe à ressocialização na medida em que se baseiam em relações simétricas, a partir de propostas de diálogo entre os presos e pessoas não presas, entre o cárcere e a sociedade livre.

"por reintegração social entende-se a reintegração das partes de um todo que têm entre si uma relação dialética, de contradições, sem que se queira dissolver as contradições. Essas partes são segmentos que compõem a sociedade, sem dúvida, mas também são segmentos contraditórios que estão dentro de cada sujeito, dentro de todos nós. (...). Não se trata de reduzir o excluído (eixo disciplinar, de Figueiredo), nem mesmo de tentar integrar o excluído, na busca de dissolução da contradição (eixo liberal), mas de se posicionar perante o excluído, de dialogar com o contraditório"

(Sá, 2011: 320).

Dentre as três perspectivas, Sá (2008) elege a sócio-psicológica como aquela de aplicação possível hoje no sistema penitenciário brasileiro. A concepção medico- psicológica fica descartada, uma vez que a própria Lei de Execução Penal já ultrapassou a concepção causalista-determinista. Já a concepção de inclusão social, apesar de representar a mais coerente do ponto de vista teórico, é de difícil realização prática no momento presente. 
Logo, restaria que projetos para a Execução Penal fossem pensados com base no conceito sócio-psicológico (psicossocial) de Criminologia Clínica, com uma abertura para as implicações do conceito crítico. Posição que não difere muito das sustentadas por Mathiesen (1989) ou Baratta (1990), qual seja: seguir um objetivo possível a curto prazo sem perder de vista o ideal a longo prazo, tratar de melhorar as condições atuais do cárcere com vistas a torná-lo cada vez menos necessário.

\subsubsection{Stanley Cohen: os perigos da proposta de reintegração}

Para Stanley Cohen (1985:77) o aparecimento da "ideologia da reintegração" trouxe mudanças expressivas no sistema correcional: reforçando a perspectiva inclusiva em detrimento de outra mais exclusiva e envolvendo outros atores na execução penal, tal como família, escola, comunidade, etc.

Porém, o autor sul-africano analisa criticamente o que chamou de "terceira revolução do correcionalismo" ou "the new $R$ in the history of corrections" 37 (1985: 76). Diferentemente dos autores supracitados, Cohen propõe uma leitura crítica e realista da participação de instituições comunitárias no sistema de justiça.

Para ele, a ideologia da reintegração, ao reverter o pressuposto do positivismo criminológico de que o delinquente é um ser essencialmente distinto dos demais, acabou por trazer o desvio "de volta pra casa", para as instituições primárias da sociedade. Pais, escola, vizinhança e até a policia tem se dedicado a manter o desviante fora do sistema de justiça formal (1985:77). Como consequência, houve uma ampliação do campo da diversion, e logo, uma penetração profunda da lógica do controle institucional no corpo social.

Ainda que a participação comunitária evite por vezes o "toque do sistema formal", o fato das instituições primárias não guardarem autonomia em relação a esse sistema, faz com que a lógica do sistema formal ainda prevaleça na maneira de tratar o desvio e o desviante.

\footnotetext{
37 Cohen fala de três revoluções da história do controle social. A primeira ocorreu na primeira parte do século XIX, na transição da vingança para contenção ("from revenge to restraint"); a segunda no final do século XIX/ início do XX da contenção para a reforma ("from restraint to reformation"); e a terceira, a partir do século XX e ainda em curso, da reforma para reintegração ("from reformation to reintegration").
} 
Logo, quando invadidas, absorvidas, penetradas, assediadas ou colonizadas pelo sistema formal (Cohen, 1985:78), as instituições da sociedade civil acabam por reafirmar as práticas e discursos do sistema a que faziam frente.

Esse diagnóstico pessimista, exposto por Cohen, foi confirmado pela análise do campo da presente pesquisa. Grande parte das instituições da sociedade civil atuantes no cárcere, são absorvidas pelo sistema de controle. A presença de uma diversidade de agentes atuando no cárcere não significa uma diversificação da lógica punitiva estatal. Como exemplificarei no decorrer da tese, os princípios e a vontade da reintegração social, tão elaborados na teoria, encontram inúmeras barreiras para se constituírem enquanto práticas autônomas e realmente integradoras.

\subsection{Reintegração social: uma síntese}

Após a breve reflexão acerca das teorias da pena e dos usos da reintegração social, cabe ao final deste capítulo delinear uma síntese com o sentido que o termo reintegração social é empregado nesta pesquisa.

Dois núcleos conformam a reintegração social: um relacionado ao cumprimento de pena (estratégias e práticas de desprisionização), e outro a ações voltadas para o egresso do sistema (benefícios e oportunidades de trabalho).

Como já explicitado, a discussão teórica aqui empreendida, assim como os projetos selecionados para constituir o campo da pesquisa, estão relacionados somente às práticas de reintegração social ocorridas dentro do espaço prisional.

Para fins da presente pesquisa, a reintegração social pode ser sintetizada como uma experiência de inclusão social, com a finalidade de diminuir a distância entre sociedade e prisão, que conta com a participação ativa do apenado e de pessoas de fora do cárcere; a partir dos seguintes pressupostos:

a) realização de um trabalho no cárcere realizado pela sociedade civil com o fim de diminuir as fronteiras entre sociedade e prisão;

b) propostas centradas em experiências significativas de inclusão social;

c) reconhecimento da dignidade e "normalidade" da pessoa presa; 
d) participação ativa e voluntária dos encarcerados, nas atividades desenvolvidas em âmbito prisional;

e) corresponsabilização da sociedade no processo de reintegração social;

f) interação sociedade-cárcere como um fim em si mesmo, e não como um meio de readequação ética do indivíduo preso.

A partir desta perspectiva, é notável o protagonismo que a sociedade civil assume em relação às estratégias de reintegração social. No capítulo seguinte, abordarei especificamente a temática da sociedade civil, relacionando-a com o Estado e a questão prisional. 


\section{CAPÍTULO 2 \\ SOCIEDADE CIVIL, ESTADO e PRISÃO}

O eixo deste segundo capítulo é a relação entre o Estado, sociedade civil e instituição prisional. Abordarei o conceito de sociedade civil, seus usos e sua relação com o Estado. Em seguida, farei uma reflexão acerca de como a punição atinge a sociedade, e como se pode, a partir dela (sociedade), alcançar a reintegração social. Nesse sentido, analisarei alguns aspectos do trabalho voluntário nas prisões: regulamentação, finalidades, impacto e limites.

\subsection{Conceito de sociedade civil}

Antes de adentrar a problemática específica do papel da sociedade civil na reintegração social, cabe delinear o sentido de sociedade civil compreendido nesta pesquisa.

Um dos elementos centrais para a definição da sociedade civil é sua oposição ao Estado. No sentido da esfera de relações sociais não reguladas pelo Estado, dois usos thes são comuns. $\mathrm{O}$ primeiro, mais abrangente, concebe a sociedade civil como tudo aquilo que não é Estado, e emprega o termo para designar a sociedade na sua forma mais ampla; o segundo, limita a sociedade civil ao que se convencionou chamar "terceiro setor", formado por Associações, Organizações não governamentais (ONGs), Organizações da Sociedade Civil de Interesse Público (OSCIPs) etc.

No meu entender, o segundo sentido parece mais adequado. A sociedade civil não deve ser equiparada à sociedade como um todo, porque, diferentemente desta, a primeira pressupõe algum grau de organização e mobilização de seus membros. A sociedade civil corresponderia, então, à sociedade reunida em torno de associações, grupos ou movimentos, ainda que não institucionalizados.

Segundo a cientista política Jean Cohen (2003: 419), o termo passou a ser invocado para tudo, "designando desde empreendimentos cívicos, associações voluntárias e organizações sem fins lucrativos até redes mundiais, organizações não-governamentais, grupos de defesa dos direitos humanos e movimentos sociais transnacionais". 
Ainda que a sociedade civil possa assumir muitas formas e abranger uma série de organizações bem diferentes entre si, dois elementos parecem comuns a todas elas- e, portanto, definidores da concepção da sociedade civil nessa pesquisa: 1. oposição à esfera estatal; 2. organização, formal ou informal, das pessoas em torno de uma causa.

Hegel foi o primeiro a cunhar o termo sociedade civil, diferenciando sociedade de Estado, contrapondo a esfera política da não-política. De acordo com Restrepo (1990: 2), o que diferencia a sociedade civil e o Estado em Hegel é a natureza- particular ou geral- do interesse que motiva as ações dos homens e do bem que se busca alcançar. As ações que derivam de um interesse particular dão origem à sociedade civil, e se inscrevem nela. Por outro lado, o Estado é produto de uma ação que obedece ao interesse geral de toda a coletividade.

Ainda sob uma ótica que opõe os interesses do Estado e da sociedade civil- porém diferente da proposta de Hegel (que associa a sociedade civil aos interesses privados)Cohen (2003: 423) contrapõe a sociedade civil não só à lógica do Estado, mas também à lógica da empresa privada ${ }^{38}$. Para a autora, a sociedade civil é pautada pela interação comunicativa e autonomia de comunicação, enquanto o Estado ou a sociedade privada, pautam-se pela perspectiva do lucro e do poder.

A teoria do italiano Antonio Gramsci (1891-1937) foi retomada por Norberto Bobbio na obra "O conceito de sociedade civil". Segundo Bobbio (1982: 29), Gramsci criou dois grandes planos superestruturais: um formado pelo "conjunto de organismos habitualmente ditos privados", e outro pela sociedade política ou Estado.

Em “Estado, Governo e Sociedade”, Bobbio (1987) observa dois tipos de definição de sociedade civil: uma negativa e outra positiva. A definição negativa é concebida a partir da definição de Estado: para se delimitar a extensão e significado de sociedade civil, estabelece-se antes a extensão e o significado do Estado, uma vez que a sociedade civil é "tudo aquilo que sobra, uma vez bem delimitado o âmbito no qual se exerce o poder estatal”. Já partindo de uma definição positiva da sociedade civil, autorreferente, que a

\footnotetext{
${ }^{38}$ Ela fala em três esferas: Estado, iniciativa privada e a sociedade civil são comumente denominadas "primeiro setor", "segundo setor" e "terceiro setor", respectivamente.
} 
define pelo o que ela é, Bobbio apresenta três diferentes abordagens para a compreensão da sociedade civil.

A primeira relaciona a sociedade civil com os sujeitos em conflitos que a compõem e sua relação com o Estado:

"a sociedade civil é o lugar onde surgem e se desenvolvem os conflitos
econômicos, sociais, ideológicos, religiosos, que as instituições estatais têm
dever de resolver ou através da mediação ou através da repressão. Sujeitos
desses conflitos, e portanto da sociedade civil exatamente enquanto
contraposta ao Estado são as classes sociais, ou mais amplamente os grupos,
os movimentos, as associações, as organizações que as representam ou se
declaram seus representantes; ao lado das organizações de classe, os grupos
de interesse, as associações de vários gêneros com fins sociais, e
indiretamente políticos, os movimentos de emancipação de grupos étnicos,
de defesa dos direitos civis, de libertação da mulher, os movimentos de
jovens, etc." (Bobbio, 1987:35)

Para uma segunda leitura, presente nas mais "recentes teorias sistêmicas da sociedade global”, as diferenças entre demandas sociais e respostas do Estado podem levar à crise de legitimidade das instituições estatais e a legitimação da sociedade civil, a partir da seguinte equação:

"a sociedade civil ocupa o espaço reservado à formação das demandas (input) que se dirigem ao sistema político e às quais o sistema político tem o dever de responder (output): o contraste entre sociedade civil e Estado põese então como contraste entre quantidade e qualidade das demandas e capacidade das instituições de dar respostas adequadas e tempestivas"

(Bobbio, 1987: 36)

Uma terceira perspectiva ancora a sociedade civil na verdade produzida e reproduzida pela opinião pública. Nesse sentido, a sociedade civil é a expressão do consenso ou dissenso do público em relação às instituições, transmitidas pelos meios de comunicação. Nesse sentido:

“opinião pública e movimentos sociais procedem lado a lado e se condicionam reciprocamente. Sem opinião pública que significa mais concretamente sem canais de transmissão da opinião pública, que se torna "pública" exatamente enquanto transmitida ao público - a esfera da sociedade civil está destinada a perder a própria função e, finalmente, a 
desaparecer. No limite, o Estado totalitário, que é o Estado no qual a sociedade civil é inteiramente absorvida pelo Estado, é um Estado sem opinião pública (isto é, com uma opinião apenas oficial)"

(Bobbio, 1987: 37)

Das três abordagens elencadas por Bobbio, interessam diretamente a esta pesquisa a primeira e a terceira. A primeira no que tange à organização dos cidadãos em grupos, associações, organizações que compõem movimentos de defesa de direitos civis, sociais e políticos das chamadas "minorias" ou das parcelas excluídas da população. A terceira interessa no momento em que relaciona sociedade civil e opinião pública, reconhecendo nesta um espaço de criação de um saber diverso do produzido pelas instituições de controle.

Hoje, com a possibilidade de interação e articulação em termos globais, a sociedade civil torna-se a depositária das esperanças de maior democratização, maior publicidade das grandes questões e maior solidariedade (Cohen, 2003: 423).

Com a democratização da produção e difusão de informações, ampliaram-se as possibilidades de formação de uma opinião pública independente, que fizesse frente às mass media. O debate público e a pluralidade de discursos acerca de temas como prisão e segurança pública permitem que mais pessoas e organizações entrem na disputa pela vontade da verdade ${ }^{39}$ penitenciária, pelos modos de se executar a pena.

A apropriação pela sociedade da questão prisional pode contribuir para:

desmistificar o lugar que a prisão ocupa na nossa sociedade;

$>$ produzir discursos e permitir falas diferentes das institucionais; 3.

$>$ dar outro rumo para as demandas da sociedade em relação ao Estado, para além do controle e da repressão.

A presença efetiva da sociedade civil nas instituições prisionais é fundamental para que outros tipos de práticas, relações e discursos passem a circular pelo cárcere e também pela

\footnotetext{
39 "Eu entendo por verdade os conjuntos de procedimentos que permitem pronunciar, a cada instante e a cada um, enunciados que serão considerados como verdadeiros. Não há, absolutamente, uma instância suprema. Há regiões onde esses efeitos de verdade são perfeitamente codificados, onde o procedimento pelos quais se pode chegar a enunciar a verdade são conhecidos previamente, regulados" (Foucault, Poder e Saber, 2006, p. 232-233)
} 
sociedade. Porque tanto a sociedade civil causa impacto na dinâmica prisional, como a experiência da "prisão" impacta os que dela se aproximam.

\subsection{Sociedade civil, punição e reintegração}

“A questão da prisão não é uma questão para um segmento, mas para todos nós".

(Mathiesen, 1997: 285)

É inegável que o crime e a pena são assuntos que comovem as pessoas. Ainda que o sistema de justiça estatal queira concentrar as respostas sociais dadas a algumas das ações desviantes e deter o monopólio do uso da violência, a reação social extrapola o âmbito estatal. Como a carga emotiva está sempre presente nas questões criminais, a punição mobiliza outras instituições sociais, e um público além do especializado.

Diametralmente contraposto à inflamada reação popular, o discurso jurídico tende a transparecer frio e racional. Mas, a todo o tempo, as paixões estão presentes no jogo da punição: no processo legislativo, na mídia, na reação popular, na individualidade dos operadores do direito, no choro das vítimas, na abordagem policial, no sofrimento dos condenados. O sistema de justiça criminal, ainda que aparentemente regido por uma racionalidade, não escapa aos apelos das subjetividades e coletividades que o conformam.

A ciência jurídica concebe a pena enquanto uma consequência lógica e imediata da prática de um crime. A contribuição de Durkheim na sua obra Da Divisão do Trabalho Social (1995), publicada originalmente em 1893, é que de alguma forma a punição movimenta emoções. Ela não é fruto de um cálculo racional e de uma operação lógica, tal como a quer o Direito.

O crime atinge o coração da sociedade, fere algo de muito profundo compartilhado pelas pessoas. Para o autor, a reação passional é característica intrínseca à pena, “a paixão, que é a alma da pena, só se detém uma vez esgotada" (1995: 57); essa paixão, ainda que exista em todas as formas de organização social, seria mais manifesta em "sociedades menos cultas". 
Com o advento da modernidade, a punição passou a ser construída a partir do discurso da racionalidade penal, porém não houve mudanças no que toca o caráter passional da punição. Para o sociólogo francês, a natureza da pena não mudou essencialmente, apenas a necessidade de vingança está mais bem dirigida.

Ainda de acordo com a perspectiva de Durkheim (1995), a maneira com que uma sociedade pune seus membros desviantes expressa os tipos de relações solidárias em seu interior. $\mathrm{O}$ modo como a sociedade trata seus criminosos define a natureza da sociedade e das relações sociais que ali se estabelecem. As instituições perseguem seus objetivos explícitos, mas indiretamente produzem uma série de outros. A punição funciona de formas que estão além do controle do crime.

Justamente por isso, uma mudança na racionalidade penal pressupõe uma mudança na forma da sociedade se relacionar com a punição e com as pessoas criminalizadas pelo sistema de justiça. Nesse sentido, é essencial que a sociedade participe do processo criminal e da aplicação da pena, e assim, retome o lugar dela no conflito gerado tanto pela conduta desviante quanto pela criminalização de alguns desses desvios.

Um envolvimento maior da sociedade civil na resolução de seus conflitos pode vir a reverter o movimento de penalização da vida social, através da substituição da lógica penal por outras, tais como política, social, afetiva, econômica.

Conforme o argumento de David Garland (1990: 252), as práticas penais produzem significados sociais fundamentais, os quais vão além do crime e castigo. A punição fala sobre poder, autoridade, legitimidade, normalidade, personalidade, relações sociais etc, além de produzir uma série de instruções sobre como significar o bem e o mal, o normal e o patológico, ordem e desordem. Os julgamentos, condenações e classificações da esfera penal são práticas que replicamos na nossa vida social.

A não-identificação com a pessoa presa, o não reconhecimento dela como um igual, faz com que seu sofrimento se torne invisível aos olhos da sociedade. De acordo com Garland (1990: 243), “o público não escuta a angústia dos prisioneiros e suas famílias, porque o discurso da mídia e da criminologia popular mostra os criminosos como 'diferentes', e menos que totalmente humanos (...) o conflito entre as sensibilidades civilizadas e a 
frequentemente brutal rotina da punição é minimizada e feita mais tolerável. A punição moderna é então institucionalmente ordenada e representada por um discurso que nega a violência inerente das suas práticas". 40

Para Mathiesen (1997: 275), a prisão se mantém enquanto elemento chave da punição, a despeito de todas as críticas e diagnósticos pessimistas, devido ao "caráter secreto da irracionalidade da prisão". Para ele, este é um dos segredos mais bem guardados em nossa sociedade. $\mathrm{O}$ embate puramente racional à instituição prisional não é suficiente para que ela seja questionada, seria necessário que as pessoas percebessem suas idiossincrasias e paradoxos a partir de "um nível emocional mais profundo".

Para o autor norueguês, três grupos de atores funcionam no sentido de proteger a instituição prisional e o segredo de sua irracionalidade: os administradores do sistema (que são disciplinados, cooptados e leais à instituição que representam); os pesquisadores e intelectuais; e os meios de comunicação em massa.

Uma linha de ação proposta por Mathiesen (1997: 284) é a criação de um “espaço público alternativo". Tarefa essa que passa pela liberação do poder dos meios de comunicação em massa, pela restauração da autoestima de movimentos e grupos que questionam o modo de funcionamento do sistema, e pela restauração do sentimento de responsabilidade dos intelectuais, artistas e pesquisadores.

Esse projeto vai ao encontro da proposta de Alessandro Baratta (1990) de reintegração social, na qual é destacada a importância da presença de membros da comunidade na dinâmica prisional, principalmente por meio de realização do trabalho voluntário. $\mathrm{O}$ voluntariado teria uma tripla função: frear os possíveis abusos a partir da visibilidade, propiciar o envolvimento social e humano dos presos com os voluntários e, ainda, estabelecer uma "relação desinteressada", que não está sob o registro relação de poder equipe dirigente - internos.

\footnotetext{
${ }^{40}$ Tradução livre. No original: "the public does not hear the anguish of prisoners and their families, because the discourses of the press and of popular criminology presents offender as 'different', and less than fully human, (...) the conflict between our civilizes sensibilities and the often brutal routines of punishment is minimized and made more tolerable. Modern penalty is thus institutionally ordered and discursively represented un ways which deny the violence which continues inhere in this practices"
} 
A abertura do cárcere para a sociedade é uma das vias da reintegração social. A presença das pessoas da sociedade civil no ambiente prisional possibilita a interação permanente entre o microcosmo prisional e o macrocosmo social, aproximando essas duas esferas, de modo que os presos possam refletir e questionar sobre as questões sociais mais amplas ${ }^{41} \mathrm{e}$ as pessoas de fora do cárcere possam vivenciar um pouco da realidade prisional.

Para Zaffaroni ${ }^{42}$ (apud Wolff, 2009: 59), a reinserção não pode ser vista somente como processo de adaptação social, mas como possibilidade de modificações de papeis assumidos a partir do estereótipo coletivo.

Ademais, a presença de pessoas estranhas à prisão e o relato delas acerca dessa experiência a outras de seu convívio (na família, escola, trabalho, igreja) contribui para a desmistificação da prisão e dos indivíduos que nelas vivem, e encoraja as pessoas a se aproximarem de seus muros.

"Essas pessoas concretas, que em sua imensa maioria, intuem que há alguma coisa de louco e de insuportável em nossa justiça criminal, por outro lado, a não ser que tenham estado, algum dia, elas mesmas presas no labirinto penal ignoram como realmente funciona o sistema"

(Hulsman, 1993: 56)

A experiência da prisão- e entrar em contato com as falas daqueles que o vivenciam- é essencial para a formação de um saber crítico sobre o cárcere. Independente das concepções que a pessoa tenha sobre a prisão, é importante que sejam afetadas pela realidade prisional- especialmente em relação àqueles que atuam no sistema de justiça criminal, em um processo em que está em jogo a liberdade de uma pessoa. Infelizmente, é comum que uma pessoa assuma e exerça a magistratura ou a promotoria criminal- com a responsabilidade de condenar e acusar pessoas- sem nunca ter pisado em uma prisão.

\footnotetext{
41 Aqui cabe relatar que durante as atividades do GDUCC do primeiro semestre de 2007, a greve da Universidade de São Paulo e a ocupação da Reitoria da Universidade pelos seus alunos despertaram grande interesse dos presos. Eles nos questionaram sobre a motivação da greve e sobre nosso posicionamento acerca das atitudes dos ocupantes. Ademais, ressaltaram a diferença de atuação da Tropa de Choque da Polícia Militar no confronto com os estudantes com a usual atitude da PM em relação a eles (presos).

42 ZAFARONI, Eugenio Raúl. Sentido y justificación de la pena. Jornadas sobre sistema penitenciario y derechos humanos. Buenos Aires: Editorial del Puerto, 1997, p. 191.
} 


\subsection{Poder público, sociedade civil e reintegração social}

Conforme discorrido no capítulo anterior, o envolvimento da sociedade civil é pressuposto para a reintegração social. Seja por meio do voluntariado ou de convênios com o poder público, é essencial que os cidadãos ocupem um espaço na relação entre instituição estatal e prisional, entre agentes estatais e presos.

Partindo do pressuposto que a reintegração social é uma experiência de inclusão social, com a finalidade de diminuir as fronteiras entre sociedade e prisão, ela não pode ser pensada sem uma sociedade civil atuante.

Quanto maior a participação da sociedade nas questões penitenciárias, mais publicidade se tem na execução penal, e consequentemente maior a informação e o controle sobre o que se passa por detrás dos muros.

Apesar de o voluntariado constituir uma ótima estratégia para o redimensionamento da necessidade de punição e do sentido da reintegração social, a volatilidade de seus membros, assim como a falta de espaço no jogo da política criminal, podem fragilizar sua atuação. A prisão, por natureza, já não é um campo de fácil acesso e inserção; o poder público, nas suas mais diversas esferas ${ }^{43}$, exerce uma "política de fechamento" das instituições prisionais, dificultando ainda mais a entrada da sociedade civil nas suas diversas formas (ONGs, pesquisadores, estudantes, associações).

Nesse sentido, as realizações de convênios entre sociedade civil e poder público se mostram importantes como meio de incentivo de práticas não-personalistas (que independam de uma pessoa para sua continuidade), e, como forma de facilitar a entrada dos membros da sociedade civil no espaço prisional.

Do pequeno levantamento que realizei em relação ao pode público, pode-se extrair algumas linhas de atuação em âmbito federal:

- formação dos agentes penitenciários;

- profissionalização/educação e cultura (DEPEN);

${ }^{43}$ As dificuldades são percebidas em todos os âmbitos, desde a demora de uma autorização da Secretaria, até o "chá de cadeira" na entrada da penitenciária- que a cada plantão exige um procedimento diferente. A burocracia que envolve o gerenciamento da prisão, e mais do que isso, o domínio de um modo de fazer penitenciário, legitimam as formas de controle da entrada e da interação de pessoas de fora do cárcere. 
- projetos voltados ao egresso e ao acesso aos direitos (CNJ).

Parte dos projetos é executada diretamente pelo poder público, e outra parte fica a cargo de instituições da sociedade civil, em convênio com o setor público. Como esta pesquisa está focada em iniciativas da sociedade civil, nos próximos capítulos irei me deter apenas a projetos realizados pela sociedade civil, com ou sem apoio público.

\subsection{Participação da comunidade na LEP e órgãos da execução penal no Brasil}

Em uma pesquisa acerca das formas de intervenção da sociedade civil no cárcere, não se poderia deixar de mencionar o tratamento que a Lei 7210/84, a chamada Lei de Execução Penal (LEP), dispende à matéria.

O fundamento da participação da comunidade na Execução Penal está prescrito no art. $4^{\circ}$ da LEP, que dispõe que o Estado deverá recorrer à cooperação da comunidade nas atividades de execução da pena e da medida de segurança.

De acordo com o art. 61 da Lei, além do Judiciário e do Ministério Público, compõem órgãos da Execução Penal: o Conselho Nacional de Política Criminal e Penitenciária (CNPCP), os Departamentos Penitenciários, o Conselho Penitenciário, o Patronato e os Conselhos da Comunidade- que devem atuar de forma harmônica e integrada.

Apresentarei brevemente esses organismos nacionais e estaduais de participação da sociedade civil na Execução Penal, a partir das disposições da LEP. No final, apresentarei algumas reflexões específicas sobre os Conselhos da Comunidade, cuja finalidade se aproxima muito dos propósitos de reintegração social trabalhados nesta pesquisa.

\subsubsection{Departamento Penitenciário Nacional (DEPEN)}

O Departamento Penitenciário Nacional, previsto nos arts. 71 e 72 da LEP, é órgão executivo da política penitenciária nacional, subordinado ao Ministério da Justiça e responsável pelo acompanhamento da aplicação das normas de Execução Penal em todo o território nacional.

Compete-lhe especificamente ${ }^{44}$ :

\footnotetext{
${ }^{44}$ Fonte: site do Ministério da Justiça,
} 
I- planejar e coordenar a política penitenciária nacional;

II - acompanhar a fiel aplicação das normas de execução penal em todo o território nacional;

III - inspecionar e fiscalizar periodicamente os estabelecimentos e serviços penais;

IV - assistir tecnicamente as unidades federativas na implementação dos princípios e regras da execução penal;

V - colaborar com as unidades federativas, mediante convênios, na implantação de estabelecimentos e serviços penais;

VI - colaborar com as unidades federativas na realização de cursos de formação de pessoal penitenciário e de ensino profissionalizante do condenado e do internado;

VII - coordenar e supervisionar os estabelecimentos penais e de internamento federais;

VIII - processar, estudar e encaminhar, na forma prevista em lei, os pedidos de indultos individuais;

IX - gerir os recursos do Fundo Penitenciário Nacional - FUNPEN; e

$\mathrm{X}$ - apoiar administrativa e financeiramente o Conselho Nacional de Política Criminal e Penitenciária.

Em 2004, o DEPEN criou o Sistema de Informações Penitenciárias- Infopen, que consiste em um programa de coleta de dados, com acesso via Internet, alimentado pelas Secretarias Estaduais com informações estratégicas sobre os estabelecimentos penais e a população prisional.

No art. 73, a LEP prevê a existência de Departamentos Penitenciários Estaduais responsáveis pela gestão penitenciária, podendo funcionar como órgão vinculado e subordinado a uma Secretaria específica. O Estado de São Paulo criou, no ano de 1993, a Secretaria de Administração Penitenciária (SAP), que conta com uma Coordenadoria de Reintegração Social e Cidadania.

\subsubsection{Patronato}

O artigo 78 da Lei de Execução Penal prevê a existência do Patronato, público ou particular, e que se destina a prestar assistência aos albergados e aos egressos (assim entendidos como os liberados definitivos, pelo prazo de um ano a contar da saída do 
estabelecimento, e os liberados condicionais, durante o período de prova) em sua reinserção social, auxiliando-os a superar as dificuldades que surgem no momento em que deixam a prisão, tais como abrigo, trabalho, documentação e acesso a serviços públicos essenciais.

De acordo com o art. 79 da LEP, cabe ao Patronato: orientar os condenados à pena restritiva de direitos, fiscalizar o cumprimento das penas de prestação de serviço à comunidade e limitação de fim de semana e colaborar na fiscalização do cumprimento das condições da suspensão e do livramento condicional.

A LEP nada dispõe acerca da composição do patronato. Porém, o mais indicado seria uma formação interdisciplinar, com a presença de advogados para prestar assessoria jurídica, assistentes sociais para trabalhar as questões de família e trabalho, psicólogos para o acompanhamento terapêutico, além de profissionais de outras áreas que possam contribuir para a reinserção do egresso.

A legislação também não estabelece como um Patronato deve ser criado, apenas se refere à sua natureza (pública ou privada). Logo, ele poderá ser criado por um órgão público, a exemplo das Secretarias e da Vara de Execuções Penais, por uma Instituição de Ensino Superior de natureza pública ou privada, ou a partir de um grupo de pessoas que se disponha a assumir as competências estabelecidas em lei.

\subsubsection{Conselho Nacional de Política Criminal e Penitenciária (CNPCP)}

O Conselho Nacional de Política Criminal e Penitenciária é um órgão subordinado ao Ministério da Justiça. É integrado por treze membros designados por ato do Ministro da Justiça. Eminentes professores e profissionais da área penal e ciências correlatas compõem o Conselho, bem como representantes da comunidade e dos Ministérios da área social. Os membros do Conselho são renovados um terço em cada ano ${ }^{45}$, e seu mandato tem a duração de dois anos.

45 
Tanto em âmbito estadual como federal, cabe ao Conselho realizar avaliações periódicas e sistemáticas do sistema penitenciário, além de propor as diretrizes da política criminal quanto à prevenção do delito, à administração da justiça criminal e à execução das penas e das medidas de segurança (LEP, arts. 62 a 64).

\subsubsection{Conselho Penitenciário}

Já o Conselho Penitenciário, órgão previsto no art. 69 da LEP, tem atuação consultiva e fiscalizatória na Execução Penal. O órgão é integrado por profissionais e professores da área penal e ciências correlatas, assim como por representantes da comunidade. Seus membros integrantes são nomeados pelo Governador do Estado, para um mandato de quatro anos. O Conselho Penitenciário tem por escopo uma atuação política em âmbito estadual, exercendo também a fiscalização dos presídios.

No exercício da função consultiva, cabe ao Conselho do órgão emitir parecer acerca de pedidos de indulto individual ou coletivo e comutação de pena, além de zelar pelo correto cumprimento do Livramento Condicional (propor revogação ou suspensão, sugerir a extinção da punibilidade em caso de integral cumprimento do Livramento Condicional etc.).

No trabalho de fiscalização, o órgão deve inspecionar os estabelecimentos e serviços penais, supervisionar os patronatos, bem como dar assistência ao egresso. Deve também apresentar ao Conselho Nacional de Política Criminal e Penitenciária, no primeiro trimestre de cada ano, um relatório das atividades exercidas no ano anterior.

\subsubsection{Conselhos Da Comunidade}

A LEP dispõe, no seu art. $1^{\circ}$, que é objetivo da execução criminal a criação de condições para a harmoniosa integração social do condenado. E prevê o envolvimento da sociedade civil nas atividades relacionadas ao sistema penitenciário, tanto em alguns de seus dispositivos como em sua exposição de motivos:

"nenhum programa destinado a enfrentar os problemas referentes ao delito, ao delinquente e à pena se completaria sem o indispensável e contínuo apoio comunitário" (item 24 da exposição de motivos) 
"Muito além da passividade ou da ausência de reação quanto às vítimas mortas ou traumatizadas, a comunidade participa ativamente do procedimento da execução, quer através de um conselho, quer através das pessoas jurídicas ou naturais que assistem ou fiscalizam não somente as reações penais em meio fechado (penas privativas de liberdade e medida de segurança detentiva) como também em meio livre (pena de multa e penas restritivas de direito)".

(item 25 da exposição de motivos)

A participação ativa da sociedade aparece explícita na letra da lei. O legislador estabeleceu, no art. $4^{\circ}$ da LEP, que "o Estado deverá recorrer à cooperação da comunidade nas atividades de execução da pena e de medida de segurança".

O Conselho da Comunidade, órgão da Execução Penal integrado por representantes de variados segmentos sociais, deverá estar presente em todas as comarcas em que existam pessoas em situação de encarceramento.

Eles serão instalados pelo Juiz da Vara de Execução Criminal da respectiva Comarca. Por previsão legal, devem ser constituídos por no mínimo 3 (três) membros, sendo um representante da Associação Comercial ou Industrial, um advogado indicado pela Seção da Ordem dos Advogados do Brasil local e um assistente social, escolhido pela Delegacia Seccional do Conselho Nacional de Assistentes Sociais.

$\mathrm{O}$ art. 81 da LEP incumbe os Conselhos da Comunidade de fiscalizar os estabelecimentos prisionais- visitando, pelo menos mensalmente, os estabelecimentos penais existentes na comarca - conversar com os presos, realizar relatórios mensais ao juiz da Vara da Execução e Conselho Penitenciário. Compete a eles ainda a obtenção de recursos (materiais e humanos) para a assistência do condenado, atuando em conjunto com a direção dos estabelecimentos penais.

De acordo com o Ministério da Justiça ${ }^{46}$, os Conselhos operam como mecanismo de reconhecimento entre sociedade civil e cárcere, e possibilitam a ação da sociedade no sentido de humanizar o cárcere, atuando dentro de uma perspectiva mais reintegradora quanto ao retorno dos presos ao convívio social.

${ }^{46}$ Portal Ministério da Justiça http://portal.mj.gov.br/data/Pages/MJD46457E9ITEMID73E7AF8064A64EDE92A30E2CF3A47B7BPTBRI E.htm, acesso 16/06/2010. 
Um dos princípios do Conselho da Comunidade enunciados pelo Ministério da Justiça é a compreensão da prisão como instituição pública integrante da sociedade e, portanto, permeável ao controle social.

A Comissão para Implementação e Acompanhamento dos Conselhos da Comunidade do DEPEN publicou a Cartilha dos Conselhos da Comunidade ${ }^{47}$. O material aborda a legislação da Execução Penal, as formas de instauração dos Conselhos, assim como princípios e funções do órgão. Fornece ainda modelos de relatório de visita à prisão e de formulário de inspeção em estabelecimento penal.

$\mathrm{Na}$ Cartilha, as ações do Conselho da Comunidade são exemplificadas a partir de seis eixos:

$>$ Representação e intermediação da comunidade: solicitação de recursos; representação nos fóruns e organizações locais e regionais; elaboração e/ou proposição de políticas integradas de atendimento aos presos, internos e egressos.

$>$ Educativa: participação e divulgação na mídia; participação em fóruns, seminários locais e regionais; e participação na formação de profissionais nas áreas de atuação de interesse do sistema prisional e em atividades junto aos presos.

$>$ Consultiva: elaboração de pareceres sobre aplicação de verbas; elaboração de pareceres sobre a situação geral do presídio e dos presos; e proposição de medidas a serem tomadas pelos órgãos públicos.

Assistencial: atendimento a famílias, presos, internos e egressos em situações emergenciais.

$>$ Auxílio material à unidade prisional: aquisição de equipamentos; participação em reformas.

$>$ Fiscalizadora: avaliação e monitoramento do cumprimento de direitos, da aplicação de verbas e do exercício da função das diferentes instituições públicas envolvidas na Execução Penal.

${ }^{47}$ Disponível no site http://portal.mj.gov.br, acesso 15/06/2010. 
Esse documento também reconhece o papel das universidades, parceiras importantes dos Conselhos, a partir de programas de ensino, de extensão universitária e de pesquisa. A assessoria técnica e a produção de saber nessa área permite aos alunos e pesquisadores um conhecimento prático da realidade prisional, além de "uma formação mais crítica e contextualizada na realidade".

Apesar de sua inegável importância, ainda é dada pouca atenção à atuação dos Conselhos. No relatório "Brasil atrás das grades", da Human Rights Watch (1998), “os Conselhos da Comunidade, locais previstos por lei- concebidos como um método significativo de encorajar o contato com a comunidade e o envolvimento com os presos- não existem na maioria das jurisdições”.

Ainda que os Conselhos da Comunidade não constituam o objeto dessa pesquisa, a problematização em torno dessa temática é cara à reflexão aqui proposta. Como minha leitura acerca dos Conselhos ainda é muito rasa, nesta breve análise me apoiarei em duas autoras: Maria Palma Wolff e Valdirene Daufemback, ambas membros do CNPCP e da Comissão Nacional de Fomento e Apoio aos Conselhos da Comunidade do Ministério da Justiça.

Na leitura de Daufemback (2009:16), os Conselhos podem, a partir da abertura de canais de comunicação e de uma atuação política, minimizar o processo de invisibilidade do encarceramento que produz estereótipos, exclusão e falta de empatia.

De acordo com Wolf (2009: 2), o Conselho da Comunidade representa a comunidade em âmbito local, incentivando a participação social na gestão e no controle de políticas públicas. Consequentemente, estimula a descentralização estatal, a partir da construção de outro tipo de hegemonia política, na qual o cidadão passe a se responsabilizar pelas escolhas políticas.

No Brasil, os Conselhos de Comunidade têm um grau de institucionalização ainda indefinido. Alguns estão constituídos enquanto ONGS, outros como sociedade de direito público, e outros ainda não possuem personalidade jurídica. 
Grande parte dos Conselhos centraliza suas ações em práticas assistencialistas, visando suprir necessidades materiais dos presídios. Dessa forma, o Conselho deixa de produzir dinâmicas próprias para assumir o papel do Estado, provendo assistência material básica. Isso se dá porque as carências de toda ordem pelas quais passam os presídios brasileiros criam um "estado constante de emergência", exigindo que toda a demanda e expectativa em relação à comunidade seja depositada no suprimento a esses recursos (Wolff, 2009:11).

Ainda de acordo com Wolff (2009: 12), as principais problemáticas ligadas aos Conselhos são: atuação concentrada no suprimento de necessidades materiais do presídio; pouca articulação com outras organizações da comunidade; não realização de intervenções junto ao egresso; dependência do judiciário ou diretor do presídio; falta de ligação entre os conselhos das esferas federal, estaduais e municipais, representados respectivamente pelo Conselho Nacional de Política Criminal e Penitenciária (CNPCP), Conselhos Penitenciários dos Estados e Conselhos da Comunidade.

Daufemback (2009: 15), em pesquisa sobre os Conselhos da Comunidade da região Sul, atesta que as principais dificuldades enfrentadas pelos Conselhos são: falta de consciência da sociedade civil, falta de apoio do sistema penitenciário (Estado), falta de recursos financeiros.

\subsection{Reintegração social e o setor público}

Nos discursos de alguns órgãos públicos responsáveis pela questão prisional, percebe-se o avanço teórico no sentido de superar a proposta de ressocialização. Porém, as práticas promovidas ou patrocinadas por essas instituições ainda ficam muito aquém do que propõem suas palavras.

Tais órgãos definem a reintegração a partir de uma perspectiva crítica, distante da ideia de mudança no modo de ser do individuo. Porém, a grande maioria das propostas práticas patrocinadas pelo setor público trabalha dentro da antiga perspectiva educação formal/ profissionalização.

Analisarei superficialmente como dois desses organismos praticam a reintegração social, a partir da comparação entre discursos e práticas promovidas ou financiadas por esses 
órgãos. São eles: em âmbito executivo federal, o Ministério da Justiça (Departamento Penitenciário Nacional- DEPEN), e, em âmbito executivo estadual, a Secretaria de Administração Penitenciária de São Paulo (SAP). Analisarei também um projeto do judiciário ("Começar de novo"), no âmbito do Conselho Nacional de Justiça, que se remete especificamente à problemática penitenciária.

Não tenho qualquer pretensão que o levantamento feito a partir de poucas fontes, alguns relatórios (DEPEN /2004, 2005, e 2006 e SAP/ 2008) e pesquisa nos sites das instituições, possa dar conta de um mapeamento das ações patrocinadas pelos poderes públicos. Meu objetivo é apenas ilustrar o que esses órgãos associam à ideia de reintegração social.

\subsubsection{Ministério da Justiça (Departamento Penitenciário Nacional- DEPEN)}

De acordo com o Ministério da Justiça ${ }^{48}$ :

"As ações de reintegração social podem ser definidas como um conjunto de intervenções técnicas, políticas e gerenciais levadas a efeito durante e após o cumprimento de penas ou medidas de segurança, no intuito de criar interfaces de aproximação entre Estado, Comunidade e as Pessoas Beneficiárias, como forma de lhes ampliar a resiliência e reduzir a vulnerabilidade frente ao sistema penal"

Para o DEPEN, a promoção dos direitos dos presos e a recomposição dos seus vínculos com a sociedade é vista como condição para sua autodeterminação responsável.

No Manual para Apresentação de Projetos de Reintegração Social e Capacitação em Serviços Penais, os projetos para patrocínio deste mesmo órgão (excetuando-se aqueles voltados à formação dos profissionais da Execução Penal) devem estar posicionados em um dos três eixos abaixo:

> eixo 1 - formação educacional, elevação da escolaridade e a educação profissional

$>$ eixo 2 - formação profissional: ingresso no mundo do trabalho após o cumprimento da pena.

$>$ eixo 3 - assistências: movimento de promoção dos direitos dos apenados, internados, egressos, dependentes e familiares, criando condições para que estes possam exercer a sua autonomia. Esse processo deve ser mediado pela inclusão dos

${ }^{48}$ http://portal.mj.gov.br/data/Pages/MJDA8C1EA2ITEMID0A92E04549BC444EBF4358C793E9539APTB RIE.htm, acesso 31/04/2010. 
beneficiários na agenda das políticas públicas de governo e pelo apoio a ações de caráter permanente, de instituições públicas e privadas, que tenham como objetivo prestar atendimento aos beneficiários na forma e nos limites da lei: material, jurídico, educacional, social, religioso e principalmente à saúde do egresso, após a edição do Plano Nacional de Saúde no Sistema Penitenciário.

O terceiro eixo, que vai além da lógica educação- profissionalização, parece bem abrangente, com possibilidade de incluir diversas outras iniciativas- desde que as propostas se destinem a atingir pelo menos um dos seguintes objetivos:

"I - No âmbito da reintegração social do preso, internado ou egresso:

a) a reintegração social da mulher presa, internada ou egressa;

b) o acesso e o reconhecimento dos direitos das pessoas presas, internadas e egressas;

c) a adesão de novas unidades federativas ao Plano Nacional de Saúde do Sistema Penitenciário ou a expansão da cobertura nas unidades federativas já qualificadas;

d) a organização, ampliação e qualificação da oferta de Educação no contexto prisional;

e) a educação profissional do preso, internado ou egresso e a sua inserção no mundo do trabalho;

f) a garantia do acesso do preso, internado ou egresso, à Justiça;

g) a criação e fortalecimento dos patronatos;

h) a qualificação e aperfeiçoamento profissional do preso, internado ou egresso, e a sua inclusão no mercado de trabalho;

i) a atenção integral à saúde dos presos, internados ou egressos, em conformidade com o Plano Nacional de Saúde no Sistema Penitenciário"

As linhas de financiamento se resumem aos seguintes temas: acesso à justiça, educação, trabalho, saúde, criação e fortalecimento dos patronatos. As alinhas $a$ e $b$ (reintegração social da mulher presa e promoção de direitos), por serem mais genéricas, abarcam diferentes tipos de ações na Execução Penal. 
No portal do Ministério da Justiça $^{49}$, constam ainda dois protocolos de intenções celebrados por este Ministério juntamente com o Centro de Integração Empresa Escola (CIEE Nacional) e com o Sistema $S^{50}$. Ambos os protocolos têm o objetivo de conjugar esforços para a reintegração social da mulher presa e egressa, através de ações que promovam: o direito, a cidadania e a dignidade social; a iniciação e a qualificação profissional; a saúde da mulher; a integração familiar e comunitária; entre outras. É interessante perceber que ambos, assim como um dos eixos dos projetos, são dirigidos especificamente à mulher presa ou egressa.

\section{- Convênios Vigentes}

Para explicitar as formas que a prática da reintegração social assume em âmbito federal, analisarei rapidamente alguns convênios firmados pelo Ministério da Justiça, tentando compreender quais as instituições convenentes, qual o objeto dos convênios, e qual a sua distribuição no território brasileiro.

Infelizmente, a lista de convênios que se encontra ${ }^{51}$ no site do Ministério da Justiça está desatualizada, e cobre apenas o período de 2004 - 2006. Porém, é a partir dela que elaborei algumas análises gráficas representativas das ações promovidas.

- Breve análise gráfica do quadro de convênios

Universo: 50 convênios (ver quadro completo dos convênios no ANEXO 2)

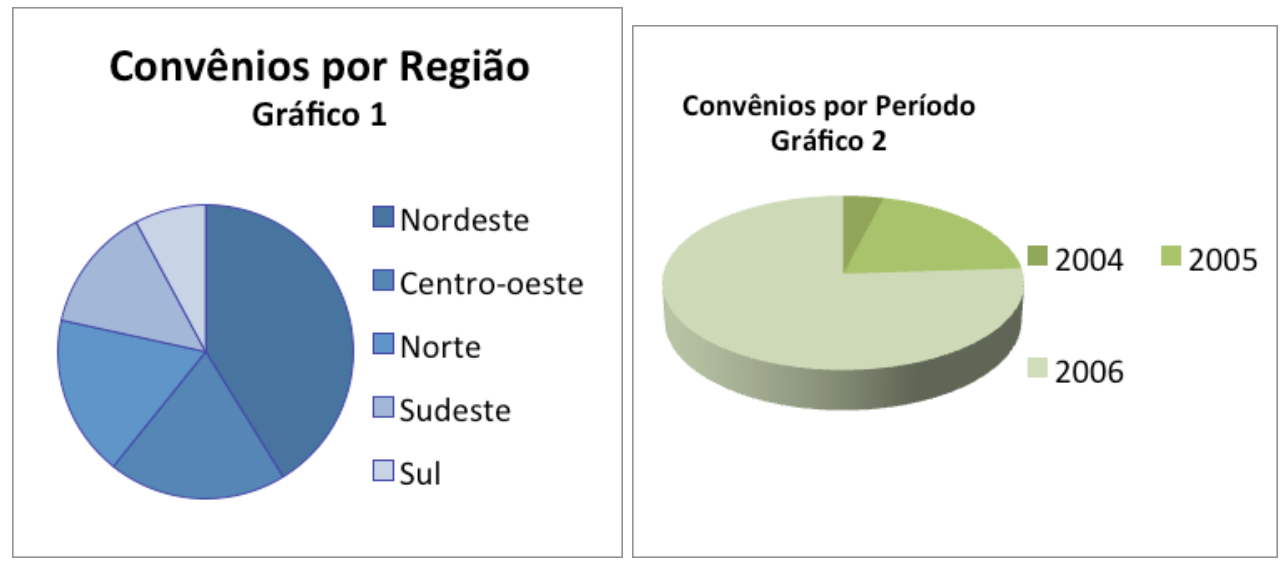

\footnotetext{
${ }^{49} \mathrm{http} / / /$ portal.mj.gov.br/data/Pages/MJDA8C1EA2ITEMID8B687DE17F0D43C8B22BEE7558A78A89PTB RIE.htm

${ }^{50}$ Que engloba o Serviço Nacional de Aprendizagem Industrial - Senai, o Serviço Social da Indústria - Sesi, o Serviço Social do Comércio - Sesc, o Serviço Nacional de Aprendizagem Comercial - Senac, e o Serviço Brasileiro de Apoio às Micro e Pequenas Empresas - Sebrae.

${ }^{51}$ Data da consulta: julho de 2010.
} 


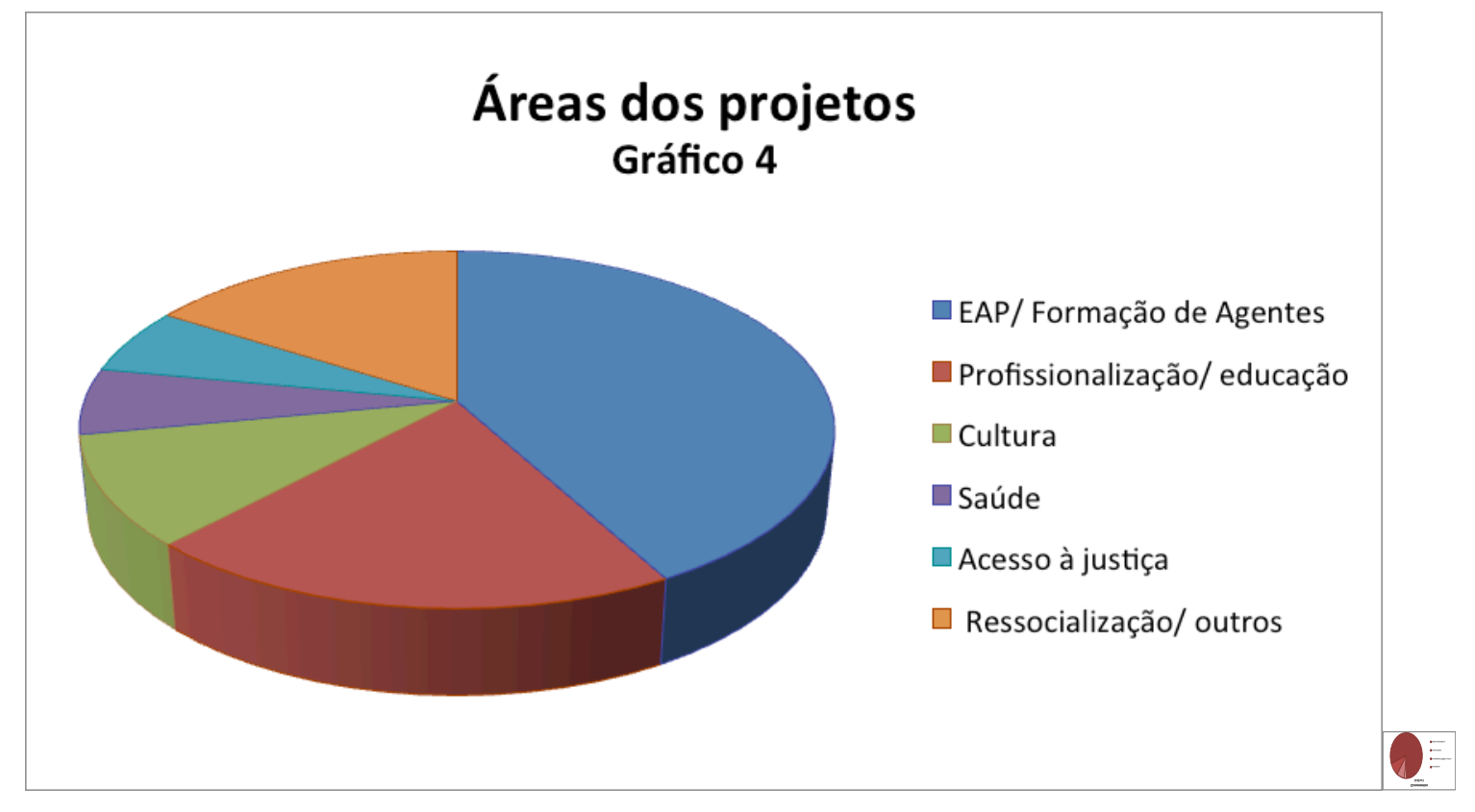

- Algumas observações metodológicas e reflexivas acerca dos gráficos

(8) No Gráfico 3, a categoria Secretarias abrange todas aquelas responsáveis pela administração prisional, cujo nome e pasta variam de Estado para Estado (Secretaria da Justiça, da Segurança Pública, da Administração Penitenciária, da Defesa Social). É interessante notar que a grande maioria dos convênios foi firmada com o poder público estadual por meio das Secretarias;

No Gráfico 4, foram considerados integrantes da área de ressocialização/outros projetos que tinham um objeto específico que não se encaixava nas outras áreas (por ex. Projeto Mente Livre: Yoga nas Prisões), ou mesmo que poderiam ser considerados multidisciplinares (como o Projeto Nascer da Terra, que além de incentivar o trabalho agrícola, prestava uma série de assistências aos presos).

(8) Também chamou atenção o fato do Projeto Arca das Letras aparecer em ao menos cinco convênios de diversos estados. A iniciativa, realizada a partir de uma parceria entre o Ministério da Justiça e o Ministério do Desenvolvimento Agrário, oferece aos presos uma pequena biblioteca, e incentiva o hábito da leitura;

(8) A maioria dos investimentos centrou-se nas Escolas de Agentes Penitenciários (EAP) e na formação dos agentes; 
(3) Houve um notável incremento no número de convênios no ano de 2006, se comparado aos anos anteriores;

(8) É interessante destacar a discrepância de convênios firmados entre as regiões do Brasil. E mesmo dentro das regiões, o destaque de alguns estados em detrimento de outros. Por exemplo, Rondônia conta com 6 convênios, enquanto outros Estados do Norte, tais como Pará, Acre, Tocantins e Roraima, não contam com nenhum.

\subsubsection{Secretaria de Administração Penitenciária de São Paulo (SAP)- Coordenadoria de Reintegração Social e Cidadania}

O Decreto $\mathrm{n}^{\mathrm{o}} 54.025$ de 2009 cria e organiza, na Secretaria da Administração Penitenciária $^{52}$, a Coordenadoria de Reintegração Social e Cidadania, que é composta pelo Departamento de Penas e Medidas Alternativas (DPMA), pelo Programa de Atenção ao Egresso e Família e pelo Grupo de Ações de Reintegração Social (GARS).

O Departamento de Penas e Medidas Alternativas (DPMA) foi criado com o objetivo de promover a expansão quantitativa e qualitativa da aplicação da pena de prestação de serviços à comunidade, bem como acompanhar e fiscalizar as já existentes, e estimular a participação comunitária nesse processo.

O Centro de Atendimento a Egressos e Familiares, através do Programa de Atenção a essa população, tem por finalidade dar assistência direta ao egresso contextualizado no seu âmbito familiar, com vistas à autonomia e postura cidadã, para que possa retomar um convívio social mais amplo.

Entre os três mencionados, o Grupo de Ações de Reintegração Social (GARS) é o que mais interessa para a presente pesquisa. O grupo seria o responsável por elaborar, acompanhar e avaliar a implementação dos programas e projetos de reintegração social nas unidades da Coordenadoria e nas unidades prisionais, dando suporte técnico, além de zelar pelo constante aprimoramento dos sistemas de acompanhamento e controle das atividades desenvolvidas na área.

\footnotetext{
${ }^{52}$ A principal fonte dos dados e informações citadas foi o Relatório de Ações do Departamento de Reintegração Social Penitenciário de agosto de 2008.
} 
O GARS avaliaria os resultados das ações de reintegração (estabelecendo indicadores para esse fim), e também o trabalho desenvolvido pelas equipes de reintegração dos estabelecimentos penais, compatibilizando-as com as propostas técnicas e opinando sobre a adequação desses servidores no exercício da função.

Assim, o GARS disponibiliza estratégias de intervenção e metodologias de trabalho, além de fomentar ações que capacitem os servidores em instrumentos de gestão e elaboração de projetos. São atribuições específicas do GARS ${ }^{53}$ :

$\checkmark$ propor e incentivar ações de reintegração social de acordo com as necessidades identificadas;

$\checkmark$ empoderar os gestores para o desenvolvimento de suas atribuições, buscando o fortalecimento da ação de reintegração como atividade final da unidade prisional;

$\checkmark$ atuar junto ao diretor geral de modo a promover a facilitação das ações do gestor de reintegração;

$\checkmark$ instrumentalizar os gestores para o desenvolvimento de uma gerência mais eficiente;

O Grupo possui ainda em sua estrutura o Centro de Referências Técnicas, que articula essas ações nas unidades através das Células de Referências Técnicas e o Centro de Políticas Específicas, que desenvolve e coordena políticas e ações para grupos específicos de idade, gênero, étnico e necessidades especiais em todos os setores da Secretaria da Administração Penitenciária.

\subsubsection{Conselho Nacional de Justiça (CNJ) - Programa Começar de Novo}

O Programa Começar de Novo $^{54}$, do Conselho Nacional de Justiça, compreende medidas voltadas para a educação e capacitação profissional de presos e egressos do sistema prisional, a partir da sensibilização de órgãos públicos e da sociedade civil. Com este programa, o CNJ espera que todos os tribunais brasileiros adotem os novos procedimentos para facilitar e agilizar a reintegração social daquelas pessoas.

\footnotetext{
${ }^{53} \mathrm{http}$ //www.relacoesinstitucionais.sp.gov.br/sis/fl/salaimprensa/documentos/SECRETARIA\%20DA\%20AD MINISTRACAO\%20PENITENCIARIA.pdf, acesso 21/06/2010.

54 http://www.cnj.jus.br/index.php?Itemid=740\&id=5826\&option=com_content\&view $=$ article, acesso $21 / 06 / 2010$.
} 
O Programa comporta as seguintes iniciativas:

- realizar campanha de mobilização para a criação de uma rede de cidadania em favor da ressocialização;

- estabelecer parcerias com associações de classe patronais, organizações civis e gestores públicos, para apoiar as ações de reinserção;

- implementar iniciativas que propiciem o fortalecimento dos Conselhos da Comunidade, para o cumprimento de sua principal atribuição legal - reintegração social da pessoa encarcerada ou submetida a medidas e penas alternativas;

- integrar os serviços sociais nos Estados para seleção dos beneficiários do projeto;

- criar banco de oportunidades de trabalho e de educação e capacitação profissional;

- acompanhar os indicadores e as metas de reinserção.

Analisando as iniciativas, depreende-se que o programa tem seu foco nas oportunidades de educação e trabalho ao preso e egresso. Porém, credita não só ao Estado a responsabilidade por esse empreendimento, mas também à sociedade civil.

O próprio Supremo Tribunal Federal anunciou a contratação de presos e egressos para trabalharem para o Tribunal. Ainda que tal medida abranja um número restrito de presos, ela guarda um simbolismo muito forte; o fato do próprio poder público, em especial a "Casa da Justiça" abrir uma porta ao preso e confiar no seu trabalho, é ao menos inspirador e poderia fomentar outras iniciativas, seja no setor público, seja no setor privado.

Como forma de incentivar tais ações, o Conselho Nacional de Justiça, por meio da Portaria $\mathrm{n}^{\mathrm{o}}$ 49, de 30 de março de 2010, estabeleceu os requisitos para outorga do selo do Projeto Começar de Novo. Para receber o selo (e incentivos fiscais), as instituições devem ofertar cursos de capacitação ou vagas de trabalho para presos, egressos, cumpridores de penas e medidas alternativas, bem como para adolescentes em conflito com a lei, além de comprovar a realização dos cursos ou contratação.

Além disso, o site do CNJ conta com um Portal de Oportunidades, que divulga vagas de cursos e empregos para presos e egressos do sistema carcerário. O site publicou também a "Cartilha do Reeducando", a ser distribuída durante os mutirões carcerários. A cartilha 
informa aos presos quais são os seus direitos e os deveres, além de dar conselhos úteis sobre como impetrar um habeas corpus, por exemplo, ou como redigir uma petição para requerimento de um benefício.

\subsection{Regulamentação do trabalho voluntário: normativa nacional e internacional}

No Brasil, a teoria e prática do trabalho voluntário são muito pouco desenvolvidas, assim como a legislação a esse respeito. Porém, de acordo com as Regras Mínimas estabelecidas pelas Nações Unidas para Tratamento dos Detentos, o Conselho da Europa e a Fundação Internacional Penal e Penitenciária, o voluntariado penitenciário deve ter acolhida expressa na legislação nacional.

\subsubsection{Regras Mínimas Para Tratamento Dos Detentos- ONU}

O Primeiro Congresso das Nações Unidas sobre prevenção do crime e tratamento de delinquentes, realizado em Genebra no ano de 1955, culminou com a adoção de regramentos denominados "Regras Mínimas para o Tratamento de Prisioneiros". Alguns dispositivos, como os de número 60.1, 60.2, 61 e 80, referem-se diretamente à participação da sociedade civil na Execução Penal.

O item 60.1. dispõe que a prisão deve reduzir as diferenças existentes entre a vida na prisão e a vida livre. E de acordo com o item 60.2 na execução penal deve-se assegurar ao preso um retorno progressivo à vida em sociedade.

O dispositivo de número 61 afirma que os presos continuam a fazer parte da sociedade, e por isso o sentimento de exclusão não deve ser reforçado na Execução Penal; para tanto, deve-se recorrer à cooperação de organismos comunitários que ajudem o pessoal do estabelecimento prisional na sua tarefa de reabilitar socialmente os presos. A interação com o mundo exterior é enfatizada na regra de número 80, para a qual o preso deve ser estimulado e auxiliado a manter ou estabelecer relações com pessoas ou organizações externas.

\subsubsection{Regras Mínimas das Nações Unidas para a Elaboração de Medidas não Privativas de Liberdade (Regras de Tóquio).}

As Regras de Tóquio, adotadas pela Assembleia Geral das Nações Unidas na sua resolução 45/110 de 14 de Dezembro de 1990, constituem-se em regras internacionais sobre as 
medidas não privativas de liberdade, e algumas delas são dedicadas à participação da comunidade (itens 17, 18 e 19).

No item 17.1, a participação comunitária é descrita como complementar à ação da administração da Justiça Penal, constituindo recurso essencial para a manutenção dos vínculos do preso com sua família e com a sociedade. E deve ser considerada como uma oportunidade para os seus membros contribuírem para a proteção da sua sociedade (17.2.).

O item 18 que trata da Compreensão e cooperação por parte do público merece ser transcrito na integra aqui:

18.1. Os poderes públicos, o setor privado e o grande público devem ser encorajados a apoiarem as organizações voluntárias que participem na aplicação das medidas não privativas de liberdade.

18.2. Devem ser regularmente organizadas conferências, seminários, simpósios e outras atividades para melhor se fazer sentir que a participação do público é necessária para a aplicação das medidas não privativas de liberdade.

18.3. É conveniente recorrer aos meios de comunicação social, sob todas as suas formas, para fazer com que o público adote uma atitude construtiva que conduza a atividades apropriadas para favorecerem uma ampla aplicação do tratamento em meio aberto e a integração social dos delinquentes.

18.4. Deve fazer-se tudo para informar o público sobre a importância do seu papel na aplicação das medidas não privativas de liberdade.

A regra do item 19.2. preceitua que os voluntários encorajem os delinquentes e as famílias a entrarem em ligação concreta com a coletividade e a ampliá-la, fornecendo-lhes conselhos e qualquer outra forma de assistencia apropriada, de acordo com os seus meios e as necessidades dos delinquentes.

\subsubsection{Regras Mínimas Para O Tratamento Do Preso No Brasil (Resolução nº 14 , de} 11 de novembro de 1994)

A legislação brasileira não trata especificamente da participação da comunidade ou do trabalho voluntário. Dois dispositivos tratam de forma genérica o tema:

Art. 36, parágrafo único - Deverá existir instalação destinada a estágio de estudantes universitários. 
Art. 57. O futuro do preso, após o cumprimento da pena, será sempre levado em conta. Deve-se animá-lo no sentido de manter ou estabelecer relações com pessoas ou órgãos externos que possam favorecer os interesses de sua família, assim como sua própria readaptação social.

A lei número 9.608/98, que dispõe sobre o serviço voluntário, em seu primeiro artigo conceitua serviço voluntário como atividade não remunerada, prestada por pessoa física a entidade pública de qualquer natureza, ou por instituição privada de fins não lucrativos, que tenha objetivos cívicos, culturais, educacionais, científicos, recreativos ou de assistência social, inclusive mutualidade.

\subsection{O voluntariado na prisão}

O fenômeno do voluntariado é antigo. No curso da história da sociedade ocidental, ao lado dos descapacitados, pobres ou necessitados, sempre estava uma alma boa e altruísta. A igreja foi, e talvez siga sendo, o grande motor dessas ações caritativas, porém hoje novos atores compõem a cena.

A atual configuração político-econômica mundial propicia condições materiais para a expansão do voluntariado. Parte privilegiada das populações das sociedades ocidentais realizam sua entrada no mercado de trabalho mais tardiamente, ou para de trabalhar em uma fase ainda ativa de sua vida. Logo, estudantes e aposentados (ao lado da igreja) constituem atualmente a base do trabalho voluntário.

Além da configuração do mercado de trabalho favorável à realização do voluntariado, os discursos em voga nesse início de século promovem o "modo de ser" solidário, manifesto no uso de expressões como terceiro setor, responsabilidade social, participação cidadã etc.

A escolha do ano de 2011 como o "Ano Europeu do Voluntariado" sinaliza a atualidade dessa temática nos dias de hoje, e uma direção política dos governos europeus pós-Welfare State de agregar e corresponsabilizar a sociedade civil pela prestação de assistência social.

A história das instituições penitenciárias foi marcada pela presença de instituições da sociedade civil. O voluntariado penitenciário, em especial na Europa, tem uma grande tradição. Desde o nascimento da prisão já se tem relatos de grupos organizados de pessoas que realizavam ações no cárcere. 
O criminólogo e jesuíta espanhol Antonio Beristain chamou a atenção para a importância e necessidade da intervenção do voluntariado dentro das instituições carcerárias. Para o autor, intervenções desse tipo, além de promoverem o desenvolvimento social e humano dos reclusos, servem como verdadeiros freios aos abusos de poder por parte das autoridades.

Ainda que se possam encontrar continuidades entre a prisão e a "vida em sociedade", os muros delimitam o dentro e o fora, tanto socialmente quanto espacialmente. O uso, pelos presos brasileiros, da expressão "mundão" para designar o que está fora é significativo nesse sentido.

O hermetismo da prisão em relação ao seu entorno é uma estratégia de defesa do monopólio de um saber-fazer institucional, determinante na constituição da dinâmica prisional.

Porém, o caráter "total" das instituições, onde o dentro e o fora podem ser percebidos mais como continuidade do que como ruptura. A prisão conta com canais que atravessam seus muros, por onde entram e saem informações, mercadorias, valores, e algumas pessoas. Dentre as pessoas que realizam o circuito dentro-fora, sem pertencer ao quadro institucional do cárcere, estão as entidades da sociedade civil e os pesquisadores que ali entram.

Esses dois personagens podem ser vistos como mediadores de "dois mundos". O papel do investigador na prisão se aproxima do voluntário na medida em que adentra um espaço de segredos, desvela alguns e publiciza na Academia, e vice-versa: leva seu saber acadêmico à prisão e chega ali com esse olhar específico, e por vezes, pode confronta presos e funcionários desde sua perspectiva externa.

A ação dos voluntários guarda analogias com a figura do porteiro, do mensageiro ou contrabandista, aquele que habita os dois mundos, o de dentro e o de fora ${ }^{55}$. O mundo dos

${ }^{55}$ Interessante marcar que um dos projetos etnografados na Catalunha, Teatrodentro montou uma peça de teatro com um grupo de preso chamada "Las fronteras entre tu y yo". 
mortos sociais, que tampouco tem direitos políticos. Nesse sentido, alude-se à figura de Hermes na mitologia grega.

Para Beristain (2000:42), o voluntariado é um recurso e um direito. Enquanto recurso, a ele podem recorrer os internos, seus familiares, bem como os profissionais penitenciários e todas as instâncias comprometidas com a justiça penal. E, enquanto direito: "todo cidadão (individual e/ou coletivamente) tem direito a colaborar e/ou participar livre e eficazmente no desenvolvimento político, social, econômico, cultural e espiritual dos concidadãos".

Apesar de Beristain afirmar que a vantagem do voluntariado é que sua relação com os internos não é uma relação de poder, já que seu interesse primeiro e central é o bem do outro, a finalidade "altruísta" desse tipo de ação não garante que ela esteja despida de poder. Conforme problematizarei nos capítulos seguintes, a ânsia de querer o bem do preso e a certeza de saber o que é melhor pra ele podem ser formas sutis de apreender sua subjetividade, e portanto, constituem em si mesmo um exercício de poder que tenta conformar o indivíduo dentro de supostos padrões de normalidade.

Porém, a ação do voluntário pode significar para o recluso antes de tudo uma experiência concreta de doação e troca. E, talvez o mais importante, como bem destaca Sá (2007: 167), é que o voluntariado é um modelo não contaminado pelas vicissitudes, pela rotina e pela cultura da prisão.

"O voluntariado elabora um tecido gratuito de pessoas e das sociedades, consciente de que o efetivo é o afetivo, e que a forma do amor supera a do ódio"

(Beristain, 2000: 32)

Retomando o sentido de sociedade civil proposto neste capítulo, o voluntariado representaria uma efetiva cooperação e participação pública nas questões carcerárias, para além da esfera privada e da esfera estatal. Segundo Beristain, o serviço voluntário não deveria ser encarado como simplesmente complementar à ação do Estado; talvez seja até o contrário, isto é, a ação do Estado é que seria complementar à do voluntariado (pelo menos no que diz respeito ao atendimento além das necessidades básicas do preso). Nesse sentido, caberia ao Estado estruturar as instituições penitenciarias para que viabilizem o trabalho do voluntário. 
Porém, não é somente a boa vontade que pode sustentar o voluntariado. O trabalho voluntário não deve ser desprovido de sistematicidade e organização. Pelo contrário, deve ter uma intervenção previamente planejada, com objetivos e metas definidas. Portanto, a base para esse trabalho não deve ser constituída a partir de pessoas "curiosas", mas sim de pessoas muito bem preparadas, que devem trabalhar de forma entrosada com os profissionais penitenciários. Conformaria, assim, o perfil do voluntário penitenciário:

"pessoa especialmente sensibilizada e formada, associada livremente, que colabora altruisticamente respeitando e potenciando o assistido, e sendo consciente de que seu trabalho lhe enriquece não menos que ao interno na instituição penitenciária"

(Beristain, 2000: 35)

Ainda segundo o mesmo autor (Beristain, 2000: 30), o voluntariado pode atuar contra avisos de poder, e pode ser um modelo cultural inovador e favorável à mudança cultural progressiva.

\subsection{Impacto do voluntário penitenciário}

"O contato horizontal entre presos e uma organização política externa causa importantes distúrbios nos aspectos das funções sociais do emprisionamento na nossa sociedade. Causar distúrbios nessas funções pode ser considerado resistência porque indiretamente afeta algumas características essenciais da estrutura social".

(Mathiesen, 1974: 77)

Ao analisar o voluntário penitenciário, nos deparamos com uma ampla gama de entidades, que diferenciam-se entre si quanto a sua história, natureza, proposta, metodologia, etc. Apesar da diversidade dos tipos de ações, algumas aproximações podem ser feitas quanto ao impacto das ações da sociedade civil no cárcere.

Nas entrevistas com os presos participantes dos projetos de intervenção da sociedade no cárcere, ${ }^{56}$, aparece uma percepção comum a quase todos eles: de que a atividade os ajuda a "sair um pouco da prisão", que por alguns (breves) momentos a interação que se cria com os voluntários os fazem “esquecer que estão na prisão".

\footnotetext{
${ }^{56}$ Outras pesquisas também apontam essa tendência, ver Braga, 2008; Graciano, 2010.
} 
Ainda que tenham diversas metodologias e objetivos, parece que a ação da sociedade civil serve, aos olhos dos internos, como uma forma de aliviar o fastígio e a monotonia da vida e conversas no cárcere, e de alguma forma relativizar o sentimento de prisionização que acompanha a vida no cárcere.

Para Beiras (2009:489), qualquer iniciativa social, política ou educativa que pressuponha a entrada na prisão de diversos setores sociais, que vão além das visitas pontuais e ensaiadas, podem contribuir para a mudança na percepção de distância e estranhamento ("lejanía y ajenidad") entre sociedade e cárcere.

A ação da sociedade no cárcere tem um impacto interno e na sociedade. A difusão do universo carcerário na sociedade através dos meios de comunicação, principalmente a partir das chamadas novas tecnologias (internet, redes) que podem "provocar o efeito de amplificar - na sociedade- toda una quantidade de vivências, acontecimentos, sucessos, iniciativas, etc. que normalmente vivem 'fechadas' no isolamento prisional" (Beiras, 2009:491).

Com o objetivo dos próprios afetados comunicarem ao exterior suas demandas e estratégias de solução, denunciarem o que ocorre no cárcere, aproximá-lo da opinião pública, tentar reduzir a imagem distante e alheia, provocar uma tomada de consciência social a respeito de uma realidade que não pode ser ignorada (Beiras, 2009: 492).

Independentemente da intenção da entidade da sociedade civil no espaço prisional, sua atuação impacta a dinâmica penitenciária. A presença de "pessoas estranhas" no ambiente prisional leva a um deslocamento espacial de funcionários e presos, e conferem uma destinação distinta aos espaços institucionais. Há uma ruptura (momentânea) do isolamento entre prisão e entorno social, o que pode atenuar (levemente) o processo de prisionização por que passa o individuo.

Esses "atores de fora", ainda que inconscientemente, travam uma disputa com o modo de "saber fazer" com o pessoal penitenciário e relativizam a tendência do cárcere de ocultar o que se passa no seu interior. A interação social entre preso - voluntário, ainda que 
controlada, cria um espaço de fala e propagação de verdades normalmente abafadas pelo dispositivo carcerário.

O adjetivo "voluntário" da ação da sociedade civil no cárcere reforça o sentido benevolente e caritativo dessa ação. Por conta disso, Molina (1997:159) propõe a utilização do termo "iniciativa social", como forma de enfatizar o compromisso social que implica a ação voluntária.

Nesse sentido, considero interessante denominar essas ações de intervenção. Intervir é atuar sobre uma realidade específica, sobre configurações políticas próprias, com o objetivo de transformar, dar novos usos, ao espaço social determinado. Na perspectiva do urbanismo, um projeto de intervenção propõe reestruturação, requalificação ou reabilitação funcional e simbólica de regiões ou edificações de uma cidade ${ }^{57}$.

Pelo fato de ser um ator externo, a importância da presença da sociedade civil no contexto penitenciário passa pela função de físcalização e denúncia social. Porém, as instituições da sociedade civil que entram no cárcere tem pouca autonomia em relação aos objetivos perseguidos pela instituição prisional, quais sejam: neutralização e retribuição. Os dados de campo, tanto em contexto paulista como catalão, apontam o controle e absorção dessas atividades por parte do poder público.

Contudo, um marco distintivo dessas formas de atuação consiste no enfrentamento (ou não) da "direção política do sistema penitenciário" (Molina, 1997:151). Qualquer que seja a ação, ela pressupõe uma tomada de posição em relação à instituição penitenciária, um nível de cumplicidade com o dispositivo de controle, um comprometimento com um projeto, um compromisso desde um determinado ponto de vista.

Para Molina (1997: 159) a reflexão que, necessariamente, antecede a ação voluntária, é sobretudo, ideológica, da qual derivam dois tipos de posicionamentos: 1) uma atitude crítica em relação à prisão e à "intervenção social", e, portanto, uma atuação implicada social e politicamente; 2) o voluntariado realizado a partir da crença que a administração penitenciária não usa todos os meios possíveis para a ressocialização; nesta posição o

\footnotetext{
${ }^{57}$ Enciclopédia Itaú Cultural de Artes Visuais: http://www.itaucultural.org.br/, acesso 25/06/2011.
} 
voluntário corre o risco de colaborar para a continuidade de um modelo institucional fracassado.

A primeira atitude corresponderia a uma critica estrutural à instituição prisão, e a seus objetivos. A segunda limita-se a uma critica conjuntural do sistema prisional, a partir da crença de que uma "boa prisão" é possível. Da mesma forma, poderíamos falar aqui em ações revolucionárias e reformadoras, respectivamente.

Stanley Cohen, na sua já clássica obra Visions of Social Control, apontava essa tendência. Desde a década de 80 do século passado, Cohen (1985:66) diagnosticava o recrutamento do voluntário em quase todos os âmbitos do sistema de controle, como uma forma rápida e crescente de privatização. Dois fatores foram motivadores de tal crescimento: a) cortes orçamentários que ocasionaram um espaço de atuação no sistema ; b) crescimento da ideologia do envolvimento comunitário. A combinação desses dois fatores, o declínio dos serviços sociais acompanhado da expansão da rede social comunitária, levou ao crescimento do fenômeno do voluntariado.

Uma agência não estatal deveria ser orientada para o cliente, com participação voluntária e autônoma em relação ao sistema de controle. Porém, a autonomia é comprometida pela dependência que essas agências tem em relação ao próprio sistema de controle, já que precisam dele para entrada nos espaços prisionais e, muitas vezes, até para manutenção econômica da entidade.

Ao analisar a atuação das agências privadas na década de 80 nos Estados Unidos, o autor verificou que, a longo prazo, as agências, principalmente as exitosas, não se mantém privadas, mas são cooptadas e absorvidas pelo aparato estatal formal. Essa mesma tendência se repete em relação às "organizações de autoajuda radicais" (radical self-help organizations), que originalmente tinham uma relação de antagonismo com o sistema de justiça estatal (Cohen, 1985: 65 e 66).

A resignação do voluntário frente às condições que lhe são impostas acabam por convertêlo num funcionário sem salário. Será visto pelo presos como tal, o que dificulta a possibilidade de alguma mudança na dinâmica social do cárcere. 
A prisão aceita mais facilmente (ou ao menos, recebe com menor resistência ${ }^{58}$ ) aqueles que colaboram com ela, os que não ouvem e que não falam além do discurso institucional. A papelada segue mais rápido pelos trâmites burocráticos (quando os segue). A atividade pode ser incorporada à rotina da prisão e muitas vezes essas novas ideias são compradas pela Administração Prisional, que passa a lhes dar suporte e propagar a ação por diversos centros.

$\mathrm{Na}$ maioria dos casos, aderir ao objetivo institucional, e manter cumplicidade com os mecanismos de poder que ali atuam, é condição básica para a atividade do voluntário em ambiente prisional. Esse que vem de fora e intermedeia a relação preso-Estado, consolando o primeiro, e, por vezes, incomodando o segundo, mas sempre dançando conforme a música da instituição.

Quando a intervenção resulta conflitiva e abala a tranquilidade institucional, é muito provável que não durará muito. A direção é quem tem a última palavra em relação a quem entra e quem não entra no Centro Penitenciário. Por meio desse controle, e de modo camuflado em infinitas escusas burocráticas, a instituição rechaça a permanência de qualquer elemento perturbador.

Um grupo que se queira manter crítico e afrontar o dispositivo carcerário enfrentará dificuldades políticas e econômicas para sua manutenção. Sempre se preferirá conceder autorização de entrada e subvenções a ações que assumam a perspectiva institucional e que não perturbem a ordem posta, ou seja, aos “grupos menos críticos” (Molina, 1997: 162).

Na minha experiência frente ao GDUCC e nos grupos que acompanhei durante o percurso da presente pesquisa, identifiquei dois riscos comuns às entidades: serem absorvidas pela instituição ou expurgadas do espaço prisional. Os riscos estão associados ao posicionamento das entidades frente aos limites e papéis impostos pela instituição. $\mathrm{O}$ voluntário, ao tentar preservar a sua autonomia, anda na corda bamba, com o risco sempre presente de sair da linha e do jogo.

\footnotetext{
58 Não nos iludamos, a prisão é por sua natureza fechada, tende a rechaçar a entrada de qualquer coisa que venha de fora, ainda que atuem com vista a realização das finalidades declaradas da pena privativa de liberdade. Conforme pude constatar na fala de alguns voluntários "cooperadores".
} 
Um documento produzindo pelo Departament de Justícia da Catalunha (SSPRJJ, 2007) adverte expressamente o voluntário desse segundo risco. Optei por expor os termos desse documento, de forma a exemplificar a posição e o discurso institucional frente à ação da entidade da sociedade civil no cárcere.

\subsection{O limite da atuação e a "síndrome do voluntariado queimado"}

A "síndrome do voluntario queimado" é uma expressão que aparece no Manual do Voluntariado da Catalunha ${ }^{59}$ (2007: 57) para definir a consequência da ação do voluntário que extrapola o discurso institucional:

"Em numerosas ocasiões, se vivenciou negativamente a entrada de profissionais dentro do marco associativo, já que uma das primeiras tarefas necessárias é a de marcar os limites. Até aonde pode ou deve chegar um voluntário? O que pode e o que não?

Às vezes, quando estamos engajados com a tarefa de intervenção como voluntário, é muito difícil (ou mesmo não se dá importância) colocar limites a nossa intervenção. Mas fazer isso é essencial porque é a única ferramenta que nos permitirá prevenir a "síndrome do burn out" 60

De acordo com o Manual, respeitar as regras impostas pela direção prisional é a condição de subsistência do voluntário. Uma das quais prescreve ao voluntário que evite a ajuda material ao preso: ainda que "se sinta mais útil atendendo uma necessidade concreta daquele que se ajuda como levando um pacote de cigarro a um interno do que somente ouvi-lo e dar o apoio à pessoa que está numa situação de desvantagem social ou discriminação".

A tarefa de evitar que o voluntário faça algo que não está previsto no seu papel institucional é incumbência do grupo. Segundo o Manual, a entidade, por meio de seus profissionais, tem que passar aos voluntários quais são os valores, ideias, princípios da instituição, para que assim trabalhem em equipe.

\footnotetext{
${ }^{59}$ Analisarei especificamente o campo catalão nos Capítulos 5 e 6.

${ }^{60}$ No original "En nombroses ocasions, s'ha viscut negativament l'entrada de professionals dintre del marc associatiu, ja que una de les primeres tasques que ha calgut és la de mar-car-ne els límits. Fins on pot o ha d'arribar un voluntari? Què pot fer i què no?

De vegades, quan fem una tasca d'intervenció com a voluntaris per a les persones, ens és molt difícil (o, fins i tot, no hi donem importància) de posar límits a la nostra intervenció. Però fer-ho és essencial, ja que és l'única eina que ens permetrà prevenir la síndrome del voluntari cremat o del burn out.",
} 
Certamente, a ação reformadora é melhor absorvida pela instituição prisional. Essa perspectiva reformista tem seu reflexo, por exemplo, no lema do voluntariado em âmbito penitenciário proclamado pelo Departament de Justícia da Catalunha: "Você pode ser a peça que falta" ${ }^{\circ 1}$. O convite para que o voluntário se torne "uma peça para que a "engrenagem funcione" revela o tipo de inserção que se espera do voluntário: uma ação colaborativa, que suprima as faltas e atuem em conjunto com a instituição.

Esse mesmo discurso aparece na demarcação dos objetivos e atuações do voluntário penitenciário. O Manual do Voluntariado prevê que as "entidades de voluntariado e a SSPRJJ trabalharão conjuntamente para a realização de um objetivo comum: contribuir no processo de reabilitação de pessoas privadas de liberdade" ${ }^{62}$.

A produção do discurso institucional constitui o exercício de um poder que demarca o espaço que deve ser ocupado por aquele que vem de fora; voluntário se limita a estar no espaço que lhe foi designado, sem questionar a orientação institucional, principalmente publicamente.

Molina (1997, p. 159) adverte que o controle institucional da prisão pode converter o voluntário em "mero colaborador, incondicional e silencioso, da instituição". Quando a entrada do voluntário não chega a perturbar a ordem prisional, não afeta sua dinâmica, rotina, é um sinal da absorção da ação voluntária por parte da instituição.

Em obra de autoria coletiva acerca da Cárcel Modelo, critica-se o trabalho de Concepción Arenal, uma das maiores defensoras do direito dos presos na Espanha:

"Fue nefasta la obra de doña Concepción Arenal, porque jamás increpó a los Gobiernos ni a las clases poderosas con la dureza que éstas merecían limitándose a señalar el mal y pedir caridad, misericordia y compasión para el preso. Este amansó la protesta de las víctimas y llegó a la conciencia de los victimarios la idea de que bastaba la caridad para corregir un mal que sólo necesitaba el cauterio de la justicia".

(Obra colectiva, 2004: 29)

\footnotetext{
${ }^{61}$ No original: "Tu pots ser la peça que ens falta"

${ }^{62}$ No original: "Les entitats de voluntariat i la han de treballar conjuntament per a la consecució d'un objectiu comú: contribuir en el procés de rehabilitació de les persones privades de llibertat".
} 
O grande risco é o voluntário ser absorvido pelo cárcere, e tornar-se parte da engrenagem a serviço da docilização. Nas partes II e III desta tese, analisarei como algumas das entidades da sociedade civil se relacionam com os limites do sistema penitenciário, administrando o risco ou sucumbindo à absorção de sua ação pela prisão. 


\section{CAPÍTULO 3}

\section{AÇÃO E REFLEXÃO: QUANDO A ACADEMIA VAI À PRISÃO}

Neste capítulo, proponho uma reflexão acerca do posicionamento da academia em relação à prisão, a partir das atitudes de recusa e resistência. Para pensar a atitude crítica do intelectual frente à problemática do encarceramento, recorrerei a duas experiências históricas que considero referências: GIP (Group d'information sur les prisons) e KROM (Norsk Forening for Kriminalreform). Ao final, apresentarei algumas reflexões acerca da relação universidade-prisão na atualidade.

\subsection{Prisão: espaço de resistência}

Prisão. Lugar em que o poder não se esconde. Onde a violência -velada ou escancarada - é sempre legítima. Espaço que emudece, petrifica. Dizem que lá o filho chora e a mãe não ouve. Reduto das sombras, sociais e psíquicas. Destino inevitável das classes perigosas e única reposta a determinados desvios. Falida, desdentada, perigosa. Forte, necessária, e sutilmente útil.

Quando se tornou tão natural segregar e esconder? Que justificativas (racionais e emocionais) encontramos para legitimar a exclusão de alguns de nós? Eles foram um dia "um de nós"? Que demônios são esses que nos assolam e devemos guardar a sete chaves? Como abrir os calabouços? E o que fazer com o que emergirá?

O saber crítico acerca das prisões e do funcionamento da justiça criminal ajuda-nos a construir as primeiras assertivas (acerca das consequências e usos do encarceramento), porém nem sempre indica caminhos para as perguntas que as seguem.

Há um visível constrangimento naqueles que coadunam com as teorias críticas ao sistema de justiça criminal- entre os quais me incluo- quando interpelados quanto ao que colocar no lugar da prisão. Os abolicionistas ${ }^{63}$ não indicam instituição ou mecanismo que possam

\footnotetext{
${ }^{63}$ Aqui me remeto especialmente ao pensamento abolicionista do holandês Louk Hulsman, que defende a substituição do complexo penal por instâncias que promovam a resolução do conflito a partir da participação direta das partes envolvidas, para que possa haver soluções menos universais e mais individualizadas de cada uma das situações-problema. Além do mais, defende a necessidade de mudança na linguagem referente ao sistema de justiça criminal (abolicionismo acadêmico), como fundamental à mudança de significações das condutas ditas desviantes. Outros importantes caminhos abolicionistas foram propostos pelos noruegueses Thomas Mathiesen e Nils Christie.
} 
substituir a prisão; para eles, não há uma fórmula que possa responder a todos os conflitos. A solução para cada caso tem de ser pensada a partir da situação concreta.

O constrangimento se dá porque não há uma resposta - ao menos não de acordo com a expectativa daquele que pergunta. E não há resposta justamente porque a luta é por eliminar "o lugar da prisão". E, ao desconstituir o espaço social da prisão, não sobrevém a preocupação do que colocar nele.

Ainda que, enquanto críticos, neguemos a necessidade ou naturalidade do lugar que a prisão ocupa em nossa sociedade, resta a dúvida de como desmistificar esse lugar; como desnaturalizar sua existência; e, principalmente, do que fazer com essa realidade (que persiste), como nos relacionar com as pessoas que a habitam enquanto percorremos esse caminho.

Mais do que denunciar a perversidade da prisão e da ação dos mecanismos de poder, vislumbrando o seu futuro desmantelamento, interessa-me problematizar a prisão enquanto realidade presente. Realidade esta, por ora inevitável, mas não totalmente intransponível. Pensar em como, a partir deste momento presente, podemos suscitar uma reflexão acerca da necessidade e das finalidades do encarceramento, da qual emerjam outras possibilidades de relacionarmos com as situações problemáticas.

Para que se responda de forma alternativa à postura que vem sendo adotada há quase dois séculos, é necessária a disposição para rever nossas exigências de punição, assim como nossa responsabilidade no conflito. E construir uma relação de alteridade com o outro e com nós mesmos.

Neste sentido, a forma de resistência e de luta ao encarceramento é a partir da própria prisão. Um mergulho nesse espaço de sombras para, a partir dele, e em conjunto com os que sofrem a ação direta deste poder, iluminar o caminho de transformação deste lugar.

\subsection{O papel do intelectual}

"O intelectual não tem mais que desempenhar o papel daquele que dá conselhos. Cabe àqueles que se batem e se debatem encontrar, eles mesmos, o projeto, as táticas, os alvos de que necessitam. O que o intelectual pode fazer é fornecer os instrumentos de análise (...)Em outros termos, fazer um 
sumario topográfico e geológico da batalha... Eis aí o papel do intelectual. Mas de maneira nenhuma dizer: eis o que vocês devem fazer!"

(Foucault, 1979: 151)

Não cabe ao intelectual dizer aos "oprimidos" como sair da situação de opressão. Primeiro porque não existe "O" oprimido ou "O" opressor. A todo tempo, exercemos e somos objeto do exercício do poder. Sujeitamos os outros, e somos sujeitados. Logo, o intelectual também é oprimido, e cabe a ele preocupar-se com as opressões que atuam sobre ele principalmente no seu exercício de reflexão, determinando as formas de olhar, pensar e construir o mundo.

E, depois, porque ninguém pode libertar o outro, principalmente quando ocupam lugares tão diversos na sociedade. Como dizer àquele que sente na carne a violência social, policial e prisional o modo que deve agir? Como vislumbrar saídas para uma trajetória que não a minha? Como julgar as escolhas do outro, não sendo o outro?

Para Foucault (1995: 231), enquanto sujeitos no mundo, todos somos objetivados em torno de três dimensões relacionais: com os regimes de verdade, com os outros e com nós mesmos. Em nossa relação com a verdade, nos constituímos enquanto sujeitos de conhecimento. Nas relações de poder, nos constituímos como sujeitos que atuam sobre os demais, e na relação ética, como sujeitos que atuam sobre si mesmos.

$\mathrm{Na}$ condição de intelectual especificico ${ }^{64}$, essas três dimensões ganham amplitude. A atuação profissional do pesquisador é justamente produzir uma verdade, um saber. Essa produção da verdade ocorre em relação com o outro, com o "sujeito de pesquisa". E na relação com a verdade e com o outro nos constituímos enquanto sujeitos, em busca da "verdade de si".

Nesse sentido, ao intelectual é fundamental a consciência do regime de verdade que está produzindo, e como sua subjetividade relacionam-se com tais saberes e poderes. De acordo com Foucault (1995: 236-237), as lutas antiautoritárias que empreendemos, além de transversais (não estão confinadas a uma forma particular de governo ou a um Estado) e imediatas (atacam as instâncias de poder mais próximas e o inimigo imediato), devem ser anárquicas.

\footnotetext{
${ }^{64}$ Foucault (1979-A: 10) contrapõe o intelectual especifico ao intelectual universal- o qual reivindica a universalidade da lei justa e deriva do "jurista-notável".
} 
Tais lutas não visam uma solução futura e abstrata (tais como liberdades legais, fim da luta de classes ou mesmo fim das prisões), tampouco exigem do pesquisador que se situe dentro de uma lógica revolucionária binária; mas que este questione o estatuto do indivíduo em face do direito de ser diferente, batalhas contra o "governo da individualização"; de enfretamento dos "regimes de saber".

\subsection{A atitude crítica}

De acordo com Foucault (2000), a atitude crítica está no exercício de reflexão sobre os modos de existência, com vista às reinvenções de possibilidades de vida e à resistência às atuais formas de sujeição. Na busca pela constituição de subjetividades cada vez mais dessujeitadas, conscientes dos pontos de penetração do saber e das formas de apropriação do poder; e, portanto mais próximas da "política de verdade".

É preciso desconfiar, recusar, limitar, questionar as formas pelas quais somos governados, e o preço que se paga por isso. Interrogar a verdade sobre seus efeitos de poder e o poder sobre seus discursos de verdade.

Por isso a crítica, para Foucault, é "arte da não-servidão voluntária", da "indocilidade refletida", a atenção ao presente a partir de uma lógica estratégica, multicausal, sem síntese ou fechamento.

Sob essa perspectiva, a verdade não pode ser entendida como a relação entre realidade e enunciado- como se fosse possível, a partir de uma operação lógica-racional, traduzir em palavras e pensamentos a realidade complexa, multifacetada e plural. A verdade está na relação entre cada um de nós com sua escrita, seu pensamento e sua vida. "Uma relação que não seja de domínio, mas de compromisso, que não seja de apropriação, mas de transformação” (Larrosa, 2004: 42).

Nesse sentido, a "tomada de lado" nas disputas de poder não compromete a cientificidade da pesquisa. Primeiro, porque a neutralidade do cientista social em relação ao objeto não existe; e depois, porque a verdade não está ligada à apreensão da realidade tal como ela é, mas tal como nós a compreendemos. 
Para Dussel (2003: 35), assumir uma perspectiva é um ato de liberdade. As decisões constituem atos próprios e políticos, e implicam sempre em posicionamentos diante de uma realidade conflituosa e dinâmica. Em relação à sociedade, não há “fora” enquanto estivermos vivos. Falando de um lugar, não há qualquer perspectiva de isenção ou neutralidade, estaremos necessariamente comprometidos.

\subsection{Abolicionismo Acadêmico}

Hulsman (1997: 197) faz uma distinção analítica entre duas posturas abolicionistas: uma de caráter de movimento social, que nega a legitimidade do sistema de justiça para lidar com as "situações problemas"; e outra concentrada na Universidade, especificamente nos Departamentos de Direito Penal e Criminologia, que busca o fim da forma atual da justiça criminal, questionando a naturalidade e necessidade da punição, e propondo uma mudança na linguagem da justiça criminal.

A atitude abolicionista em âmbito acadêmico se traduz na construção dos elementos que envolvem a problemática penal a partir de uma abordagem não convencional, a qual permita aos estudantes interrogarem-se quanto aos usos do sistema de justiça, questionarem sua necessidade e vislumbrarem outras formas de lidar com situações problemáticas.

Da mesma forma que Foucault, Hulsman posiciona o intelectual crítico do sistema penal não como condutor do movimento social, mas como mais um ator empenhado na luta pelo fim da justiça penal. Em Hulsman, assim como em Christie e Mathiesen, existe a denúncia da inércia dos intelectuais, que promovem a continuidade de um discurso legitimador da estrutura penal vigente (Angotti, 2009: 256).

O abolicionismo acadêmico pretende uma ruptura com linguagens e discursos que propagam a continuidade da justiça criminal. Hulsman (1985: 102) lembra-nos que, diante de uma situação problemática, surge uma imensa gama de possibilidades de interpretações e reações, sendo que o significado que se atribui à ação influenciará no tipo de resposta que será dada a ela (reação). A simples utilização da denominação crime/delito para designar determinados comportamentos problemáticos já exclui outras formas de reação social que não a punitiva. 


\subsection{O diálogo enquanto caminho}

Nesse caminho, não há o lugar da "Grande Recusa", mas das resistências (no plural). As resistências são pontuais, localizadas, respondem a diversas ações do poder e são elas mesmas poderes. A multiplicidade nas formas de resistir pode ser compreendida não só a partir da diversidade dos mecanismos de poder atuantes, mas também por meio das diferentes estratégias daqueles que resistem, e das específicas condições históricas que situam a relação.

Dentro das minhas concepções teóricas e éticas, e a partir do lugar social que ocupo, penso que iniciativas que promovam a (re) integração social entre as pessoas do cárcere e o "mundo livre", a partir do diálogo sincero (compreensivo e dialético) entre esses dois segmentos, são formas de resistência contra a lógica que segrega e separa.

Aqui não se trata da integração de um sujeito excluído com outro incluído socialmentecomo comumente aparece nas chamadas ideologias "res" (ressocialização, reeducação e até reintegração). Mas da comunicação de múltiplos segmentos que estão ao mesmo tempo incluídos e excluídos, incluindo e excluindo. A sociedade que exclui é a mesma que inclui e integra.

A abertura de diálogo entre a comunidade e a prisão pode flexibilizar o fechamento característico da instituição prisional, possibilitando assim a redução do impacto da prisão sobre a vida do condenado e de todos que de alguma forma se relacionam com ele. Portanto, uma diminuição qualitativa do encarceramento.

A aproximação de segmentos historicamente antagônicos pode, ainda, levar a uma identificação de seus atores; não no sentido de criar laços pessoais entre eles, mas de permitir que um se reconheça na humanidade do outro. $\mathrm{O}$ desenvolvimento da alteridade, da aceitação do outro, pode levar à reavaliação das necessidades sociais e psíquicas da punição e da prisão, possibilitando assim uma diminuição quantitativa do encarceramento.

Além disso, o diálogo abre a possibilidade de desejo de vida de linguagem desses grupos (Fischer, 2003: 376). Possibilita que a interação social passe por outros temas e assuma outras formas, diferentes das que vinham sendo desenvolvidas desde então; e que, daí, outras formas de subjetividade possam emergir. 
O caminho para repensar o sistema criminal passa por uma mudança profunda na forma do indivíduo e da sociedade olhar os comportamentos problemáticos e reagir a eles. Não consigo vislumbrar outra forma de abdicarmos do sistema criminal (ou ao menos fazer um uso mínimo dele), senão a partir da construção de uma sociedade- e de individualidadesmais compreensiva e inclusiva.

Para a psicanálise, o estranho não é novo ou alheio, mas algo que foi alienado pela repressão. O estranho é antes de tudo um familiar, ligado a um desejo reprimido, que só se torna estranho porque não posso admitir sua familiaridade, e logo, fazer emergir o desejo (Souza e Gallo, 2002).

Quando estabeleço uma relação de identificação com o outro, reconheço-o como pertencente à mesma humanidade que eu. Eu sou o outro e o outro sou eu. Nada existe no outro, que não pertença à minha humanidade, ainda que teimemos em nos esconder das partes que não nos agradam. Logo, ao matar o outro, mato um pouco de mim. Ao prender o outro, aprisiono parte de mim. Ao libertar o outro, liberto-me da tarefa de julgá-lo e vigiálo, libertando também a mim.

\subsection{Na prisão e contra ela: recusa e resistência}

“... lá onde há poder há resistência e, no entanto (ou melhor, por isso mesmo) esta nunca se encontra em posição de exterioridade em relação ao poder. Deve-se afirmar que estamos necessariamente "no" poder, que dele não se escapa, que não existe relativamente a ele, exterior absoluto por estarmos inelutavelmente submetidos à lei? Isso seria desconhecer o caráter estritamente relacional das relações de poder. Elas não podem existir senão em função de uma multiplicidade de pontos de resistência que representavam, nas relações de poder, o papel de adversário, de alvo, de apoio, de saliência que permite a preensão".

(Foucault, 2005: 91)

A busca pela liberdade não se dá fora das relações de poder. Assim como a ação do poder está presente o tempo todo, presentes estão liberdades e linhas de fuga. Agir com vistas a acabar com o poder, ou mesmo domesticá-lo, é alimentar uma ilusão de um mundo sem poder. Essa utopia, antes do que um horizonte a se alcançar, pode nos desviar do caminho 
de pensar possibilidades subversivas nos termos do próprio poder (Deacon e Parker, 2002: 106).

Contrariando muitas previsões, a prisão sobrevive mais forte do que nunca. O fato de seu fim não parecer próximo- as taxas de encarceramento cresceram vertiginosamente nas últimas décadas- desafia a capacidade de resistir. Mais estratégica do que a recusa da realidade prisão é a resistência que passa pelos "núcleos irredutíveis de liberdade", uma vez que nunca se é totalmente sujeitado.

Essa atitude - de evitar a recusa pura e simples- não se confunde com uma atitude de cumplicidade com o poder ou com a instituição prisional. Ao contrário, enquanto resiste-se e subverte-se a ordem a partir da estrutura de poder, questiona-se esse regime de verdade, que faz "ser quem somos" e que punamos da forma que fazemos.

Resistir aqui é perceber diferente do que se vê, exercitar a dúvida, desnaturalizar a vontade de punição. Para experimentar outras formas de lidar com o desvio, com a culpa e com a responsabilidade, importa compreender qual regime de verdade é esse para o qual a única resposta social ao desvio é a punição, o castigo, o isolamento.

\subsection{Experiências referências: GIP e KROM}

Uma das grandes preocupações que norteiam meu trabalho na prisão é como atuar no cárcere, sem que isso signifique uma legitimação de sua existência ou o reforço às ideologias de reabilitação que não acredito.

Não há modelos a seguir, uma vez que cada tempo e espaço guardam uma singularidade no tocante à dinâmica prisional e às relações de força em jogo naquele espaço. Porém, conhecer os métodos de se relacionar com a prisão escolhidos por intelectuais críticoscujas teorias se tornaram referencias na minha forma de ver o cárcere - certamente pode ser inspirador para nossas ações.

Apresentarei a seguir duas experiências-referências de intercâmbio entre sociedade civilcárcere. Considerei-as referências. Primeiro, porque partiram de pessoas do meio acadêmico cujas teorias foram formadoras das minhas concepções acerca do cárcere, e por falarem a partir de um lugar (academia) que também é o que eu ocupo na dinâmica social. 
Depois, porque suas práticas traduzem minha ideia de reintegração social durante a execução penal: ambas criaram possibilidades de diálogo com o cárcere, fizeram com que a voz do preso ecoasse, e que, de alguma forma, a sociedade se voltasse para o debate em questão.

O primeiro é o GIP (Group d'information sur les prisons) criado por Michel Foucault e outros intelectuais franceses, que existiu entre 1970 e 1972; o segundo é o KROM (Norsk Forening for Kriminalreform) criado em 1968 e ativo até hoje, tendo a frente o criminólogo norueguês Thomas Mathiesen.

Porém, nem um nem outro serão tomados como modelos ideais a serem replicados no Brasil, mas tidos como referências para pensarmos nossos próprios caminhos. Pois, como bem alertou o próprio Mathiesen (2000: 1), uma organização desse tipo deve se desenvolver de acordo com a cultura e especificidades nacionais.

\subsubsection{GIP (Group d'information sur les prisons): intolerância ativa}

"Aproveitemos a brecha: que o intolerável imposto pela força e pelo silêncio, cesse de ser aceito. Nossa inquirição não foi feita para acumular conhecimentos, mas para aumentar nossa intolerância e fazer dela uma intolerância ativa".

(Foucault, Sobre as prisões, 2006: 4)

Em 1970, Michel Foucault, juntamente com outros dois intelectuais franceses (Jean-Marie Domenach e Pierre Vidal-Naquet), assinou um manifesto de criação do Grupo de Informação sobre as Prisões (GIP) como forma de lutar contra "as barreiras do silêncio", e revelar o que se passava no interior das prisões francesas.

Logo de início, o GIP rompe com as concepções críticas em voga na época, recusando a visão marxista de que presos comuns deveriam ser "conscientizados" da opressão do sistema de poder (capitalista). O GIP, ao contrário, reconhece que os presos comuns teriam, eles mesmos, a consciência de sua opressão, e que eles deveriam escolher as armas de batalha e as estratégias de luta. 
A partir de uma análise documental do arquivo do $\mathrm{GIP}^{65}$ organizado por Philippe Artiéres, Laurent Quero e Michelle Zaancatini-Fournel (que contém manifestos, publicações, fotos, enquetes) e do texto Sobre as Prisões de Michel Foucault (2006) ${ }^{66}$, pretendo depreender os objetivos e estratégias do grupo, desde seu nascimento em 1970 até sua dissolução em dezembro de 1972.

\section{Contexto histórico}

Nos anos 70 do século passado, a questão prisional estava no centro do debate político. Assim como no Brasil, o debate acerca da prisão na França ganhou força quando os filhos da classe média, intelectuais, estudantes passaram a ser encarcerados. Essas pessoas passaram a exigir o reconhecimento de sua condição de presos políticos e usavam a greve de fome como instrumento de pressão. Como consequência desse movimento, a violência institucional nas prisões alcançou visibilidade na sociedade, assim como a luta daqueles que estavam presos.

Em uma declaração à imprensa (Archive d'une lutte: 65), Foucault afirma que foi uma greve de fome organizada por presos políticos que colocou pela primeira vez na opinião pública o debate sobre o problema da prisão, e não somente da "prisão política", mas da prisão como um todo.

A referida greve de fome foi vitoriosa, e permitiu que os presos organizassem coletivamente suas lutas e formulassem reivindicações precisas. Foi durante uma conferência do GIP que Foucault transmitiu uma mensagem dos presos à imprensa. A abertura desse canal de comunicação possibilitou aos presos apelarem diretamente à opinião pública, e com isso receber o apoio de organizações e movimentos da sociedade.

Uma das estratégias de ação do GIP foi a realização de inquirições ${ }^{67}$. A primeira ocorreu na primavera de 1971, e as reivindicações dos presos surgidas daí fizeram eco em uma brochura publicada pelo GIP: Enquête dans vingt prisons.

\footnotetext{
${ }^{65}$ Le group información sur les prisons. Archive d'une lutte 1970-1972. Paris: Editions de L'imec, 2003. Para as referências a esse dossiê que aparecem ao longo do texto usarei a forma simplificada: Archive d'une lutte, seguida da página correspondente.

${ }^{66}$ Publicado originalmente em 1971

${ }^{67}$ No original em francês enquêtes. Aqui, seguimos a escolha de Vera Lúcia Ribeiro, responsável pela tradução para o português deste e dos outros textos de Foucault reunidos em Ditos e Escritos IV, 2006.
} 
A partir desse momento, o GIP mobilizou a sociedade, com o apoio da imprensa, realizando uma campanha para a sensibilização aos problemas da prisão e da justiça. Entre fevereiro e junho de 1972, uma série de dossiês foi publicada nos principais jornais franceses da época ${ }^{68}$, trazendo ao público a emergência do debate prisional.

\section{Objetivos}

O objetivo central do GIP era tornar públicas as condições reais das prisões, a partir de uma comunicação coordenada com os presos e com a população. Suas ações não tinham uma finalidade reformista, tal como alcançar melhorias do sistema prisional. O grupo buscava não uma prisão ideal, mas que os presos pudessem dizer o que é intolerável dentro do sistema de repressão penal. Sua ação consistia em uma luta contra a arbitrariedade a partir de lugares estratégicos (Archive d'une lutte : 80).

Nesse sentido, não se tratava de se colocar no lugar dos presos, falar em nome deles; mas de conhecer suas condições, a partir deles mesmos. As ações do GIP objetivavam produzir informação sobre a população penitenciária a partir dos próprios presos e familiares, visando tornar público o que não é noticiado, dito, publicado. Por meio da presença de diversas pessoas na prisão, a informação produzida por quem sofre a ação do poder penal na pele poderia ter eco na sociedade. O GIP reuniu também uma série de testemunhos sobre a prisão a partir de escritos biográficos produzidos pelos presos.

As propostas-proposições que o GIP levou a cabo não eram técnicas, mas humanas; elas se apoiavam sobre uma experiência vivida no interior do cárcere. Essa escolha pela não "tecnificação" da questão prisional, emergia como um contraponto à postura do então Ministro da Justiça francês, René Pleven, que havia delegado aos técnicos a tarefa de por fim às mazelas do sistema prisional.

Parte da imprensa acusou o GIP de subversão, de ser responsável por orquestrar a revolta dos presos naquele início dos anos 70 (nessa época, ocorreu uma série de revoltas nas prisões, não só francesas, mas norte-americanas também ${ }^{69}$ ).

\footnotetext{
${ }^{68}$ Le Monde, Le Fígaro, Le Nouvel Observateur, L'Express.

${ }^{69}$ Uma das mais marcantes foi a Rebelião de Attica, no Estado de Nova York, em setembro de 1971, cujo desfecho foi dramático. Na manhã do quinto dia da rebelião, a polícia invadiu a penitenciária, empregando bombas de gás lacrimogêneo e atirando. Foram registrados 43 mortos, 11 carcereiros-reféns e 32 presos, bem como mais de 80 feridos.
} 
Deleuze, em reação a tal acusação, escreve um texto chamado "Ce que les prisonniers attend vous" (Archive d'une lutte : 194) em que fala da necessidade de uma base popular ativa também no exterior das prisões, para sustentar e propagar as reivindicações surgidas em seu interior.

Nesse mesmo texto, o filósofo francês retrata o surgimento de outra forma de discutir a prisão com a população local: a "confissão pública", que consistiria em um encontro dos antigos detentos com a população local da cidade em que eles cumpriram sua pena. Nesses encontros os egressos diziam acerca de sua experiência prisional, produzindo dessa forma uma crítica específica. Na cidade de Nancy uma dessas reuniões reuniu mil pessoas.

\section{A forma de organização}

No GIP a luta era coletiva, o grupo transversal e composto por uma diversidade de atores. A organização foi formada por intelectuais, por inúmeros profissionais liberais (jornalistas, médicos, advogados) e por três grupos de pessoas diretamente vinculadas ao mundo prisional: os presos, seus familiares, e trabalhadores dessas instituições. Em menos de cinco semanas centenas de pessoas já participavam do grupo.

O GIP aboliu a hierarquia dentro de um grupo onde todos eram "especialistas do intolerável". Fazia um trabalho descentralizado a partir de grupos locais, que colhiam as informações das prisões e enviavam-nas à base parisiense.

Mais do que uma organização, o GIP era uma mobilização:

"não se trata de um organismo estruturado, com um comitê e um secretariado. É antes de tudo uma rede de voluntários, de pessoas de todas as espécies que se mobilizam elas mesmas. Com o objetivo de devolver aos familiares dos presos e aos próprios presos consciência de sua dignidade"

(Archive d'une lutte: 222)

Em um documento interno do GIP (Archive d'une lutte: 233), na primavera de 1972, o grupo analisa a possibilidade de fazer dos bairros (quartiers) uma segunda frente de luta ${ }^{70}$.

${ }^{70}$ Essa proposta foi inspirada no trabalho do grupo italiano Lotta Continua- com o qual o GIP trocava experiências. 
Logo, a ação se organizaria a partir de dois subgrupos: "group prison" e "group de quartier" $^{\prime 71}$.

Os quartiers formariam uma segunda frente de luta. Unidades onde se exerceria o controle da justiça e o ataque ao aparelho judiciário, a partir do apoio àqueles alvos preferenciais do sistema de justiça criminal (jovens) e da compreensão de suas ações.

Domenach (Archive d'une lutte: 222) se diz convicto que nossa sociedade não será transformada a partir das infraestruturas econômicas, mas a partir das superestruturas, onde o homem se relaciona com o homem. Uma evolução no sentido de diminuição do encarceramento só seria possível com a participação da população. Os presos querem e devem falar direto à população, inclusive porque a hostilidade da população para com os presos dificulta que mudanças ocorram no âmbito prisional.

A brochura "Cahiers de revendications sortis de prisons lors de récentes révoltes", publicada pelo GIP em abril de 1972, continha as reivindicações dos presos de diversas prisões francesas. É interessante notar que as reivindicações dos presos estavam mais dirigidas à população do que à Administração Penitenciária.

\section{O papel dos presos}

“A reinserção social dos presos só pode ser obra dos presos por eles mesmos" 72

(Declaração da imprensa, Archive d'une lutte: 187)

Todo o movimento do GIP visou que os presos se apropriassem de suas lutas. O grupo acreditava na possibilidade dos próprios presos construírem uma teoria sobre a prisão. Só lhes faltavam os meios. Não cabia ao grupo falar em seu nome, mas dar-lhes a palavra:

"Trata-se de dar a palavra àqueles que têm uma experiência da prisão. Não porque precisem que os ajudemos a 'tomar consciência': a consciência da opressão está ali... Mas o sistema atual the recusa os meios de se formular, se organizar".

(Foucault, 2006:4)

\footnotetext{
71 "Grupo prisão" e "grupo do bairro", respectivamente.

72 Tradução livre, no original em francês "La réinsertion sociale dès prisonniers ne saurait être que l'ouvre des prisonniers eux-mêmes".
} 
No texto assinado pelo grupo "Nous voulons savoir" (Archive d'une lute: 48), aparece um pressuposto que acompanhará o grupo até o fim: não se colocar no lugar dos presos, mas conhecer suas condições e respeitar sua palavra; não falar sobre eles, mas dar condições para que eles verbalizem sua vivência prisional.

Outro cuidado do grupo era o de não julgar as formas de ação coletiva que os presos escolheram para sustentar ou expressar suas reivindicações, tais como as revoltas ou manifestações mais violentas (Foucault, Archive d'une lutte: 193).

Em uma entrevista, Alain Gesmar- egresso da prisão e participante ativo do GIP- verbaliza que os acontecimentos são sentidos na prisão de forma mais forte do que fora dela, uma vez que lá o preso não se distrai de suas emoções, sente as coisas todas cruas (Archive d'une lutte: 177). Daí a potencialidade dos presos se apropriarem de suas lutas tendo como motor a dor da opressão.

Na declaração de imprensa do GIP datada de janeiro de 1971 (Archive d'une lutte: 187) aparece a necessidade imperiosa de se instituir um comitê de presos, eleitos democraticamente, em cada estabelecimento prisional. Esses representantes teriam a possibilidade de dialogar com a direção, fazendo reivindicações precisas em nome dos detentos ${ }^{73}$.

Nesse mesmo sentido de estabelecer o diálogo em detrimento da força, é proposta a criação de uma comissão mista, composta por membros da direção, educadores, "guardas" e líderes dos presos para discutir as questões que surgem na dinâmica prisional.

\section{Ações do grupo}

A ação do GIP se centrava basicamente em duas tarefas: acompanhar o movimento de coordenação das ações de presos de diferentes estabelecimentos; e usar de sua visibilidade para transmitir reivindicações coletivas, informações, denúncias e artigos sobre as prisões.

\footnotetext{
${ }^{73}$ Tal proposta nos remete a uma experiência única de participação política dos presos no Brasil. Em meados dos anos 80, o então Secretário da Justiça José Carlos Dias, cria as Comissões de Solidariedade, formadas por presos eleitos por voto direto e secreto de seus pares, e responsável por levar adiante as demandas de seus representados.
} 
Uma carta dirigida ao Ministro da Justiça, René Pleven, demonstra a tentativa dos presos estabelecerem um diálogo sincero e claro com os administradores prisionais, enquanto estratégia de luta por suas reivindicações.

A estratégia não se mostrou bem sucedida, e as solicitações não foram atendidas. Para Deleuze, entre as reformas de Pleven e as reivindicações mais moderadas dos presos há um abismo que exprime as relações de classe, de força e de poder em toda a sua nudez (Archive d'une lutte: 194).

Em um documento interno do GIP da primavera de 1972 (Archive d'une lutte: 231), são descritas as principais formas de mobilização do grupo à época:

vigiar as prisões e multiplicar os grupos em seu entorno. A partir da presença de militantes nas filas de espera, de visitantes;

$>$ pesquisas-respostas, como a realizada com as famílias em Fleury-Mérogis depois de um "espancamento";

$>$ ligar as prisões entre si, com a entrada de jornais e distribuição dos folhetos pelas prisões;

$>$ ajudar na organização de famílias: assistência, berçário, cuidado com as crianças (Toulouse), apoio de um trabalhador preso;

$>$ luta coletiva pelo respeito aos direitos (direito à visita e denúncia dos juízes);

$>$ apoiar as lutas, conhecer seus objetivos, popularizá-las, construir um "cerco exterior";

$>$ requerer a entrada e ver como por fim à arbitrariedade em relação às manifestações

$>$ ajudar as famílias de rebelados em Toul;

$>$ multiplicar os "grupos prisão", criando inclusive uma associação composta de familiares e cidadãos, e conquistar o direito dos presos se tornarem membros.

Interessante notar que, nessa descrição, diversas das mobilizações fazem menção a ações em um local determinado e em resposta a um acontecimento. Este fato aponta para a aplicação de um dos princípios norteadores do grupo: a luta pontual, localizada, específica.

Além dessas medidas, uma série de outras foram pensadas com o intuito de reunir pessoas para participarem do debate acerca das prisões (Archive d'une lutte : 232). Os fóruns 
populares, organizados nos bairros, estações, portas de fábricas, seriam uma forma de reconstruir a visão da população em relação aos presos, a partir das seguintes estratégias:

$\checkmark$ relatos de história de vida de ex-detentos, desde sua primeira prisão até a série de reincidências que a seguiram. Ver concretamente quem é levado à prisão e sua trajetória. Trata-se de liberar a palavra dos "libertados" (egressos);

$\checkmark$ reunião de um grupo de jovens com a população de esquerda de um bairro, para discutirem a hostilidade, rejeição, desemprego, salários etc., possibilitando a mobilização social contra a opressão da vida cotidiana a partir da união da população;

$\checkmark$ participação de intelectuais (atores, psiquiatras, professores) em manifestações nas portas das prisões, e principalmente em debates com a população, fazendo a ligação entre os grupos da prisão e os grupos dos bairros;

$\checkmark$ consolidação dos grupos dos bairros (group de quartier) a partir de uma mobilização ideológica. Esses grupos poderiam apoiar os jovens constantemente perseguidos pela repressão judiciária.

$\checkmark$ luta pela contratação de pessoas que tiveram uma passagem pela justiça criminal ou mesmo para que elas obtenham uma habitação de tipo popular (HLM)

De forma geral, as ações do GIP contaram com grande cobertura dos meios de comunicação na época. A ampla publicidade dada ao GIP se deve, principalmente, ao envolvimento de personalidades influentes no meio artístico e intelectual francês. Uma conferência do GIP na porta do Ministério da Justiça em janeiro de 1972 ilustra bem o tamanho de seu prestígio: lá estavam presentes Michel Foucault, Gilles Deleuze, Godard, Sartre. A reunião de tantas figuras de grande importância nacional e até mundial, atraiu a imprensa, contribuindo para impulsionar o debate acerca da prisão.

\section{As inquirições}

Dentre as principais ações do GIP, estavam as "inquirições" (enquête). Estas consistiam em uma série de perguntas acerca das condições das prisões, feitas aos familiares dos presos nos dias da visita ou sob a forma de questionários que eram distribuídos clandestinamente pelos próprios detentos. 
A reunião dessas inquirições deu origem à brochura realizada pelo GIP publicada em 1971 com o nome Enquête dans vingt prisons (Foucault, 2006: 28), que, mais do que um simples balanço da situação prisional, simbolizava a tomada da palavra pelos presos:

"... essa primeira inquirição não busca propor um modelo de reexame do problema, mas para assegurar que a palavra sufocada dos presos possa emergir do silêncio em que ela se encontra e se coloque em circulação a produção de todos os discursos que esperam e exigem porta-vozes autorizados" ${ }^{74}$

(Archive d'une lutte: 47)

Segundo Foucault (2006: 81) as enquetes não seriam destinadas a melhorar, adoçar, ou tornar o poder opressivo mais suportável. Elas constituem uma ação política, destinadas a atacar a justiça, a técnica e o saber em exercício em determinado espaço; constituindo, portanto, lutas pontuais.

Elas devem derrubar as barreiras do poder, reunir presos, juízes, advogados. Cada enquete deve ser em si um ato político, o primeiro episódio de uma luta, um front de ataque.

As enquetes abordavam as principais questões relacionadas às condições materiais de detenção: alimentação, saúde, disciplina, visitas, banho de sol, cartas, assistência jurídica, lazer, trabalho.

Não se tratava de um trabalho sociológico ou curioso, mas intolerante (Archive d'une lutte: 55). Em uma das declarações à imprensa (Archive d'une lutte: 189), afirma-se que as proposições não são elaborações técnicas, mas humanas: vêm do interior da prisão, daqueles que sentem na pele a opressão, e, por isso, são as únicas válidas. Nesse sentido, as inquirições:

- não se destinam a melhorar o poder opressivo, mas atacar o poder;

- visam alvos precisos;

- fazem cair barreiras indispensáveis ao poder, reunindo detentos, advogados, e marginais;

- não são feitas do exterior por um grupo de técnicos, mas de dentro.

${ }^{74}$ Tradução livre, no original em francês: "cette première enquête cherche no pas à imposer un modèle de contre-expertise le problème, mais à faire en sorte que la parole étouffée dès prisonniers puisse sortir du silence où on la teinte, en court-circuitant la production de tous les discours attendus et obligés de porte-parole autorisés" 


\subsubsection{KROM - Norsk Forening for Kriminalreform (Associação Norueguesa para Reforma Penal)}

O KROM foi escolhido, juntamente com o GIP, para compor o cenário das experiênciasreferências de estratégias de reintegração social. Dois são os motivos que fazem do KROM uma experiência-referência: primeiro, por constituir um desdobramento prático da teoria abolicionista proposta por Thomas Mathiesen ${ }^{75}$, e depois, pelo fato de ele ter resistido ao tempo e sobrevindo a todas as transformações ocorridas no campo penal e social nas últimas quatro décadas ${ }^{76}$.

Compreender as mudanças que acompanharam o grupo nessa trajetória, deslocando nosso olhar do ideário revolucionário da década de 1970 para os dias de hoje, pode ajudar-nos a refletir sobre o tempo presente e as possibilidades que se abrem nesse início de século.

As informações acerca do KROM foram extraídas basicamente de três fontes: do site da $\operatorname{organização~}^{77}$; do artigo de Knut Papendorf ${ }^{78}$ (2006): 'The Unfinished': Reflections on the Norwegian Prison Movement"; e de textos de Thomas Mathiesen, especificamente dos artigos "La política del abolicionismo" (1989) e "O caminho do século XXI-Abolição, um sonho impossivel?" (1997) e "Hva er KROM. About KROM -Past-Present-Future" (2000).

\section{Contexto histórico}

Em meados da década de 60 do século passado, começa a se desenvolver o "movimento escandinavo de prisões". O marco inicial desse movimento foi um grande encontro, em 1966, no qual presos e egressos, pela primeira vez na Escandinávia (e talvez na história internacional), falaram ao público e à imprensa acerca de suas experiências na prisão. Esse acontecimento ficou conhecido como "Parlamento dos Ladrões"79 (Mathiesen, 2000: 2)

\footnotetext{
${ }^{75}$ Thomas Mathiesen é professor de sociologia do direito na Universidade de Oslo. Ele foi o primeiro presidente da KROM, e em toda a sua história foi um membro ativo participante da organização. É considerado um dos principais teóricos do abolicionismo penal.

760 KROM norueguês surge no ápice da critica ao sistema penal dos anos 70 do século passado, sobrevive ao recrudescimento penal dos anos 80 e 90, e se mantém ativo até hoje.

${ }^{77} \mathrm{http}$ ://www.krom.no, acesso 15/03/2010.

${ }_{79}^{7}$ Pesquisador do Instituto de Criminologia e Sociologia do Direito da Universidade de Oslo, Noruega.

79 "Parliament of Thieves".
} 
A partir de então, foram criadas diversas associações ${ }^{80}$ nacionais focadas na questão penitenciária. Ainda no ano de 1966 foi criado o KRUM na Suécia. Em seguida, estabeleceu-se o KRIM na Dinamarca (1967), na Finlândia (1968) e o KROM $^{81}$ na Noruega (1968).

Nossa análise do movimento escandinavo ficará restrita ao grupo norueguês. Três são os motivos: primeiro, o KROM é o único ${ }^{82}$ que existe até hoje e mantém propósitos próximos daqueles de quando foi criado; segundo, porque a produção teórica acerca das atividades do KROM é muito superior se comparada às dos outros grupos; e depois, porque a Noruega, entre os países escandinavos, é o lugar onde as discussões criminológicas e abolicionistas tiveram mais fôlego.

Os primeiros membros do KROM foram intelectuais e pessoas politicamente engajadas, que começaram a defender pontos de vista em grande parte desconhecidos dos presos em geral e dos membros presos do KROM (Papendorf, 2006: 128).

Mathiesen (2000: 3) aponta quatro fatores que ensejaram o surgimento do KROM:

1. uma insatisfação reprimida, e uma vontade por parte dos intelectuais, cientistas, trabalhadores, advogados e cientistas sociais de fazer alguma coisa com "a situação de prisão";

2. a preocupação em envolver os presos na ação política enquanto participantes ativos (o que na época era uma novidade e causou grande alarme e repercussão nos meios de comunicação);

3. atuar enfatizando a supressão das prisões. Logo em seu início, o KROM propunha a reforma do sistema prisional. Mais tarde, porém, passa a defender a perspectiva abolicionista;

\footnotetext{
${ }^{80}$ Para um panorama dos movimentos e grupos de criminólogos críticos nacionais e internacionais ver Shecaira, 2004, pp. 328-329.

${ }^{81}$ A nomenclatura varia de país para país, se utiliza KRUM na Suécia, KRIM ((Kriminalpolitisk Forening) na Dinamarca e na Finlândia e KROM na Noruega.

82 Apesar do KRIM dinamarquês ainda se manter ativo, atualmente ele concentra sua atuação atendendo pessoas que necessitam de assistência jurídica gratuita ou tem queixas da polícia ou da justiça. Mais informações podem ser encontradas no site http://www.krim.dk/, acesso 02/05/2010.
} 
4. os membros do KROM concebiam o trabalho político como uma experiência de aprendizagem, e acreditavam que tal experiência em si era parte do objetivo do grupo.

II. Objetivos

O objetivo central do KROM é a ampliação da discussão do sistema carcerário por diferentes setores da sociedade norueguesa, buscando desmascarar as tradicionais ideologias no campo da política penal.

Desde o inicio, Mathiesen teve uma atuação importantíssima, denunciando a irracionalidade do sistema de justiça criminal: as falácias da prevenção geral, do potencial de reabilitação e de outras justificações para a pena. O caminho do abolicionismo, para Mathiesen, estava em uma ação política radical, concebida a partir de sua experiência com o KROM.

A partir de 1968, o grupo, que até então tinha objetivos de cunho humanitários e reformistas (explicitados inclusive no próprio nome do grupo: reforma criminal), passa a enfatizar e aprofundar sua atuação política.

Em 1974, Mathiesen publica sua obra clássica “The politics of abolition" (1974: 46-68), onde ele fixa os objetivos principais do KROM:

$>$ A longo prazo, mudar o pensamento geral em relação ao castigo e substituir o sistema carcerário por medidas mais modernas e adequadas (objetivo revolucionário)

A curto prazo, derrubar todos os muros que não forem necessários: humanizar as distintas formas de detenção e aliviar o sofrimento que a sociedade impinge aos presos (objetivo reformista)

Mathiesen adota uma perspectiva estratégica para que as ações com o objetivo de humanização desenvolvidas nas prisões não criassem obstáculos para se alcançar o 
objetivo abolicionista em longo prazo. As reformas deveriam ter então um cunho "negativo", no sentido do antiencarceramento:

"quando se trabalhara por melhoras imediatas do sistema carcerário, fizerase-o por meio de reformas que negaram a estrutura base das prisões. Posteriormente, essas reformas poderiam chegar a consolidar o sistema, mas ao menos em sua concepção eram anticarcerárias" 83

(Mathiesen, 1989: 110)

III. "Learning experience" e "the unfinished": o caminho se faz caminhando

As noções de movimento inacabado (the unfinished) ${ }^{84}$ e de experiência de aprendizagem (learning experience) sempre acompanharam o KROM. A ação política é concebida pelos seus ativistas enquanto um processo, uma experiência inacabada, uma aprendizagem, onde a luta em si compõe o objetivo.

Os erros, retrocessos, são considerados não como perda de tempo, mas como aprendizados úteis e necessários à caminhada. A preocupação do KROM era consolidar "um movimento político que transcenda os limites, seja vital, expansivo e 'inacabado'" (Folter, 2008: 195). O inacabado visto não como um defeito, mas como uma possibilidade política:

"As ideias de Mathiesen sobre o estabelecimento do inacabado baseiam-se no temor de que, ao escolher alternativas acabadas, todas as mudanças estruturais se transformem em uma mudança marginal que na realidade não afetaria a ordem predominante"

(Folter, 2008: 194)

Tal postura fez com que o grupo desenvolvesse paciência e a certeza de que o caminho se faz caminhando. Essa perspectiva fez com que muito dos ativistas do KROM classificassem a atuação do grupo enquanto "pesquisa ação" e valorizassem a

\footnotetext{
${ }^{83}$ Tradução livre. Na edição em espanhol: "cuando se trabajara por mejoras inmediatas del sistema carcelario, se lo hiciera por reformas que negaran la estructura de base de las cárceles. Posteriormente estas reformas podrían llegar a consolidar el sistema, pero al menos en su concepción era anticarcelarias".

${ }^{84}$ A noção de um movimento inacabado tornou-se tão importante que resultou em um livro de autoria de Mathiesen intitulado, The Unfinished e publicado internacionalmente sob o título The Politics of Abolition (1974).
} 
sistematização ${ }^{85}$ de experiências, princípios, estratégias, táticas, como forma de reflexão sobre suas práticas.

\section{O papel dos presos}

Mathiesen (2000: 4) vê como característica central do KROM o envolvimento direto dos presos, por isso mesmo denominados por ele de "grass roots" $" 86$. A principal dificuldade em assegurar a participação dos presos nas ações do grupo, a despeito do grande interesse que os próprios tinham em participar, era o fechamento intrínseco à instituição prisional e aos diversos empecilhos criados pela administração prisional para dificultar a comunicação com os internos.

Hoje, a organização conta com um total de 200 membros, dos quais $20 \%$ são presos ou egressos do sistema. Mathiesen (2000: 4) relata a existência de conflitos entre presos e não presos, principalmente na crítica feita pelos primeiros do caráter academicista do KROM. Inclusive, chama atenção o fato dos presos, principalmente dos primeiros anos do grupo, exigirem que o KROM se engajasse na prática de reabilitação criminal.

Apesar de algumas divergências entre presos e intelectuais, nunca houve uma ruptura no grupo. Porém, observaram-se ao menos duas fraturas: a criação de uma organização exclusiva de presos denominada SON (Straffedes Orhanisasjon i Norge), que recebeu verba estatal para percorrer os fins da reabilitação, e trabalhou de forma mais prática com os egressos do sistema, enquanto o KROM manteve seu caráter de organização política.

Papendorf (2006: 130) ressalta a importância dos presos poderem se comunicar com o que ele denominou "público ativo" (active public), ou seja, instituições que transitam entre os presos e o público em geral, tais como partidos políticos, organizações políticas etc. e atuam como defensores da perspectivas dos presos. Sem esse contato horizontal com esses grupos ou pessoas, seria impossível que o preso se tornasse politicamente ativo.

\footnotetext{
${ }^{85}$ A mesma preocupação tivemos na coordenação do GDUCC, experiência que será retratada no Capítulo 8. ${ }^{86}$ Referente a "raízes"
} 
V. Ações do grupo

Logo de início, as ações do KROM alcançaram resultados concretos. O grupo conseguiu a abolição de trabalhos forçados para alcoólatras, assim como o fim dos reformatórios (escolas de trabalho) para jovens infratores, que compunham o chamado sistema borstal.

Papendorf (2006: 128) relata a estratégia para a abolição do sistema borstal: influenciar processos parlamentares e criar uma pressão externa, através da mobilização da opinião pública.

O objetivo do KROM não era a reforma dos borstals, mas a sua negação e recusa, através da tática de "desmascaramento" desse sistema. Outra tática utilizada pelo KROM foi nunca apresentar alternativas ou modelos para melhoria das instituições correcionais. Este mesmo modelo de argumentação tinha sido seguido durante a luta para abolir o sistema de trabalho forçado.

A principal tarefa da organização foi centralizar a fundada crítica científica, já conhecida na comunidade acadêmica, expandindo seu alcance até a opinião e políticas públicas (Papendorf, 2006: 129).

Um dos meios importantes de ampliação do debate é a Conferência Anual de Politica Criminal, organizada pelo KROM, cujo intuito é o debate do sistema carcerário por diferentes setores da sociedade norueguesa: operadores do sistema penal, juízes, promotores, políticos, estudantes, professores, leigos, presos e representantes da mídia.

Segundo Mathiesen (1997: 285), nos primeiros anos da conferência, a participação era restrita. Com o passar dos anos, foi se ampliando até se tornar praticamente "obrigatória" para alguns círculos de profissionais nos dias de hoje.

Além da Conferência Anual, o KROM promove Seminários e é responsável por algumas publicações, entre elas, livros de autoria de pesquisadores do grupo e o informativo KROM-News, que contém artigos escritos pelos presos e documenta algumas práticas concretas da prisão. 
O KROM sobrevive hoje graças à expectativa dos presos pela continuidade do trabalho, ao vigor trazido pelos novos membros (em sua maioria estudantes de direito) ${ }^{87}$, e a uma espécie de "comunidade moral", ou seja, um núcleo de participantes que não estão diretamente envolvidos, mas que estão sempre presentes de alguma forma.

A base do KROM assenta-se sobre o trabalho voluntário, ou seja, sua continuidade depende da vontade das pessoas usarem seu tempo livre para se dedicarem ao grupo. Para Mathiesen (2000: 8), a raiva e a consternação dessas pessoas em relação ao sistema prisional são elementos chaves para que essa dedicação perdure.

\section{Reforma positiva: objetivo palpável na atualidade}

É comum que se cobre dos críticos do sistema de justiça criminal que estes proponham soluções para melhorar ou substituir o atual sistema. Mathiesen responde a essa cobrança desincumbindo-se dessa tarefa: mais do que construir alternativas, a luta consiste na redução do sistema de justiça criminal (Mathiesen, 1989: 118).

Em sua origem, o KROM aparece como movimento de reforma, para, em seguida, adotar uma perspectiva abolicionista; inclusive, recusando alternativas ao sistema, devido à lentidão das transformações fora da perspectiva da abolição.

Porém, com o recrudescimento penal dos anos 1980/1990, o KROM passa a redimensionar o seu objetivo: concentra-se somente em reduzir a expansão do sistema penal. A partir de então, a ação do KROM passou a ser muito mais defensiva, mais no sentido de redução do que de abolição do sistema penal. O objetivo abolicionista passa a ser considerado mais como um ideal, importante para nortear a caminhada, mas dificilmente alcançável.

Em seus escritos mais recentes, Mathiesen afirma que conceber objetivos realísticos é essencial para se manter no debate sobre a política criminal. É preciso sustentar a crítica, a polaridade, sob pena da discussão se concentrar nas mãos de poucos e somente em uma direção.

\footnotetext{
${ }^{87}$ Inseridos em um projeto de assistência jurídica gratuita organizada por estudantes, chamado "Juss Buss" ou "Lei Bus", foi um importante canal de recrutamento desses jovens.
} 
Nesse sentido, seu pensamento se aproxima muito da minha concepção do que fazer com a realidade prisional que persiste. Para ele, as prisões são desumanas, e aqueles que lá vivem continuam nas piores condições possíveis; enquanto tivermos prisões, é importante tentar proporcionar uma vida mais digna para os que estão presos. Nesse sentido, pode-se dizer que hoje o KROM trabalha no sentido de reformas mais positivas.

Mathiesen (1997:284; 2000:10) tem apontando para a urgência de ser criar um "espaço público alternativo" ${ }^{\$ 8}$ na área de política penal, em substituição ao espaço superficial consolidado pelos meios de comunicação de massa, que vende violência como entretenimento.

Para o desenvolvimento dessa alternativa, três componentes seriam necessários:

- liberar o poder absorvente dos meios de comunicação em massa, ou seja, possibilitar que pessoas, eventos, discursos existam independentemente da comunicação midiática ${ }^{89}$. E, ainda, negar-se a contribuir com programas que desvirtuam nossos discursos e servem somente ao entretenimento;

- restaurar a autoestima e a confiança dos movimentos organizados a partir da população ("de baixo para cima");

- restaurar o sentimento de responsabilidade por parte dos intelectuais. Aqui Mathiesen faz referência não somente aos estudiosos do sistema de justiça criminal, mas aos intelectuais de todo o gênero: artistas, escritores, músicos, atores; além de pesquisadores de outras áreas das humanidades; de forma que, conscientes e reunidos, exerçam algum poder sobre a mídia.

O grande trunfo da criação de um espaço público alternativo é que sua base está nas relações solidárias e concretas entre as pessoas. Enquanto o espaço público midiático é fraco, segmentado, "espalhado por milhões de indivíduos conectados", sua alternativa se assenta em "relações organizadas e reais entre as pessoas" (Mathiesen, 1997: 286).

Essa possibilidade das pessoas se auto-organizarem e se comunicarem para além do espaço midiático foi ampliada com a chegada da internet enquanto nova tecnologia da informação.

\footnotetext{
${ }^{88}$ Em norueguês alternative offentilighet, em inglês alternative public space.

${ }^{89}$ Interessante pensar aqui no caso brasileiro. Os presos mencionam com orgulho e com certo status o fato de terem suas performances retratadas em um noticiário popular, ainda que em tom pejorativo e policialesco.
} 
Ela possibilitou a criação de vias duplas de comunicação, pelas quais as pessoas comuns não só são receptoras de informação, mas estão a todo tempo construindo suas realidades. A democratização da produção de informação somada à ampliação das redes sociais pode significar um grande passo na construção desse espaço público alternativo ${ }^{90}$.

\subsection{A universidade e a prisão na atualidade}

Como lócus privilegiado do ensino, pesquisa e desenvolvimento de um olhar crítico, a universidade tem um importante papel de transformação social, não se restringindo à reprodução do conhecimento e à formação de profissionais, mas expandindo-se enquanto um espaço de reflexão sobre a criação da realidade carcerária, uma vez que nela também se constrói o saber que legitima o funcionamento do sistema punitivo.

A academia deve, neste sentido, pensar alternativas para o enfrentamento dos graves problemas gerados por uma política criminal vulnerabilizante, estigmatizante, encarceradora e punitiva. Deve propor uma nova política integrativa, que se preocupe com o indivíduo e se emancipe das categorias tradicionais criadas pela própria criminologia e pelo direito penal.

Uma política acadêmica voltada para o penitenciário, com o intuito de aproximar essas instituições e aprofundar o conhecimento real sobre o cárcere e os presos. E que influencie a representação social da delinquência, além de contribuir para a formação dos profissionais que trabalharão direta ou indiretamente com a questão penitenciária (Perano, 2009: 679-680).

Beristain (2000: 46) espera que os universitários ${ }^{91}$, e em geral os cidadãos, retomem o movimento de voluntariado: "com satisfação encontramos em algumas salas e corredores de universidades anúncio e pôsteres de estudantes que se oferecem para trabalhar e organizar tarefas de voluntariado em campos diversos, e concretamente no campo penitenciário".

\footnotetext{
${ }^{90}$ No Brasil temos a experiência da rede social Instituto de Criminologia e Alteridade, que se pretende um espaço de troca transdisciplinar, que se situe em um momento diferente para pensar e deslegitimar as razões da violência, http://criminologiaealteridade.ning.com/, acesso 11/05/2010.

${ }^{91}$ Beristain narra a experiência do Community Service Volunteers na Inglaterra. Interessante o dado que os voluntários, nesse caso, são recrutados somente por indicação, já que no passado o recrutamento por meio de anúncios nos jornais, atraiu um alto percentual de neuróticos.
} 
Uma das formas de atuação é justamente ampliar os canais de interação presídiocomunidade por meio de programas de debates entre presos e universidade. De acordo com Sá (2007:181): "a grande meta, o grande compromisso da Academia em relação à questão penitenciária, seria exercer uma liderança frente à sociedade no sentido de buscar reatar as relações com aquela população de excluídos, procurando inclusive reparar os danos por eles sofridos e assim restaurar os valores, as capacidades, enfim, a cidadania que neles ainda existem".

Porém, além da mudança na postura acadêmica, cabe aos alunos e professores um desafio pessoal: estabelecer as relações com os presos, de forma que elas sejam as mais simétricas e empáticas possíveis, restaurando a confiança e a relação de um com outro; e que sejam ao mesmo tempo dialéticas, com espaço para a divergência, para o confronto.

Os presos, de modo geral, desconfiam da presença de pesquisadores (e de entidades da sociedade civil na prisão ${ }^{92}$ ). Em muitos casos, eles receiam seu uso como "cobaias", ou temem ter sua "mente" analisadas por aqueles que vêm de fora- o que demonstra a familiaridade dessas pessoas com o saber do exame como forma de produção de verdade sobre suas vidas.

Ainda que os presos (com certa razão) desconfiem da presença de atores estranhos ao cárcere, eles reconhecem a importância de estabelecer um canal de comunicação com a Academia, como meio de tornar pública a sua experiência na prisão. Conforme ilustram algumas falas de presos participantes do GDUCC $^{93}$ :

"Bom que vocês vão mostrar para o povo lá de fora que nós (presos) não somos o que pensam da gente"

"Gostei do projeto... Vocês vão levar esse debate pra sociedade preconceituosa?"

"A sociedade cobra muito. Exige os direitos dela e esquece de abrir a porta"

A entrada da universidade na prisão é um dos caminhos para que os acontecimentos e discursos da prisão transcendam seus muros. A experiência de pesquisadores, professores e estudantes na prisão causa impacto direto ou indireto nas pesquisas, publicações, projetos,

92 Retomarei esse tema no Capítulo 8.

${ }^{93}$ Caderno de campo GDUCC, Parada Neto, novembro de 2007. 
aulas, congressos, imprensa. Para Molina (1997:163), a intervenção no cárcere deve constituir uma forma de denúncia social das situações lá vividas, e da deterioração pessoal que elas implicam, de forma que a sociedade se responsabilize e sensibilize com a temática da prisão.

Além do impacto externo, a presença da sociedade na prisão contribui para diversificar a interação social e inserir outras dinâmicas no espaço prisional. De tal sorte, que a intervenção no cárcere possa diminuir efeitos da prisionização, contribuir para a formação integral do preso e ajudá-lo a sobreviver na prisão (Molina, 1997: 150).

Jésus Valverde Molina, professor da Faculdade de Psicologia da Universidad Complutense de Madrid e coordenador de diversos programas de intervenção em contexto penitenciário, produziu uma série de reflexões acerca das possibilidades de ação no cárcere desde a academia. Em suas práticas e produções, Molina tenta integrar as três funções da universidade: ensino-pesquisa-extensão.

Ao apontar as duas direções do seu modelo de intervenção, o espanhol parece retomar a proposta de Mathiesen (1974) para pensar objetivos a longo e a curto prazo. A longo prazo, deve-se buscar alternativas à prisão. A curto prazo, programas de intervenção aos presos que sejam paliativos à deterioração que supõe a prisão (Molina, 1997:163).

Retomo algumas de suas ideias (Molina, 1997: 138, 139) sobre a intervenções que me parecem pertinentes para pensar uma ação com o objetivo de "superar o cárcere":

$\checkmark$ não incorporar a prisão como um dos elementos da intervenção. Segundo o autor, trabalha-se no cárcere porque ali está o indivíduo, e não porque a prisão seja ou possa a vir a ser um contexto terapêutico;

$\checkmark$ tomar o contexto penitenciário como elemento importante e por vezes insuperável da intervenção;

$\checkmark$ o programa de intervenção deve ter como objetivo superar a prisão, afastando o perigo de resignar-se frente ao irremediável da situação;

$\checkmark \quad$ as estratégias de intervenção no ambiente prisional devem ser pensadas com o fim de modificar as estruturas penitenciárias; 
não contribuir com a crença de que algumas melhorias humanitárias poderiam resolver os problemas da prisão. Afinal, qualquer prisão, ainda que melhor, será ruim;

$\checkmark$ a prisão deve incidir sobre as consequências do emprisionamento, não sobre a "conduta desadaptada".

Na obra "La cárcel y sus consecuencias: la intervención sobre la conducta desadaptada" (Molina, 1997), o professor compartilha as escolhas e dificuldades de suas propostas de intervenção, e narra o processo de expulsão de um de seus grupos da prisão, depois de criticá-la. Segundo o autor:

"Trabajar en el interior de las prisiones no tiene por qué implicar hacerse
corresponsable de la situación de las cárceles, ni apoyar a la institución, ni
aceptar el internamiento penitenciario como algo deseable o no siquiera
como inevitable. Puede implicar todo lo contrario: comprometerse con el
preso y con su futuro, ofreciéndole solidaridad y la oportunidad de que
pueda volver a encontrar el control de su propia vida, es decir, aportándole
la intervención recuperadora y el encuentro personal que la cárcel le
niega" (Molina, 1997: 81)

Ao final, Molina (1997: 168) adverte para alguns riscos da aproximação cárcereuniversidade: intelectualização do problema, como autodefesa do acadêmico frente à uma realidade profundamente violenta; inexperiência dos alunos participantes do projeto $^{94}$; e orientação do grupo da universidade em termos de intervenção na dinâmica prisional, muito distinta da desejada pela instituição penitenciária.

Os problemas apontados por Molina são muito parecidos aos enfrentados por outros grupos que propõe um trabalho no cárcere. Os dois primeiros riscos estão relacionados diretamente à academia, e foram identificados em alguns dos nove grupos que compõem o campo de análise desta tese, dos quais cinco foram formados desde a universidade ${ }^{95}$.

\footnotetext{
94 Segundo Molina, era comum que os alunos nutrissem uma atração inicial pelo mórbido e confundissem compromisso com caridade.

${ }_{95}$ Abrir la cárcel, FAS, Projeto Leiturativa, IACC e GDUCC.
} 
Já a divergência entre objetivos do grupo e interesses institucionais parece ser comum a todos as entidades que intervém no cárcere. Conforme analisarei mais adiante, o embate com a instituição carcerária pode ter duas consequências nefastas para o grupo: ser absorvido pela prisão ou expulso dela. A entidade da sociedade civil caminha sobre uma linha tênue, ao tentar preservar sua autonomia e ao mesmo tempo, manter-se no espaço prisional.

Iñaki Rivera Beiras, criminólogo da Universitat de Barcelona, um dos fundadores do Observatori del Sistema Penal i els Drets Humans (OSPDH) ${ }^{96}$ e coordenador do projeto “Abrir la cárcel” (1999) ${ }^{97}$, também problematiza sobre a relação entre academia e cárcere e os riscos inerentes a ela.

O OSPDH, foi criado em 2001 no âmbito da Universitat de Barcelona após o fim do projeto "Abril la cárcel" (1999) por divergências com a administração prisional. E, desde então, constitui-se em uma plataforma reivindicativa que se busca traduzir em autênticas alternativas à prisão, a partir da reunião de diversos setores afetados pela prisão e entornos sociais e profissionais comprometidos com esse trabalho. (OSPDH 2004: 318).

O Observatori tem como finalidade aprofundar a participação democrática de setores excluídos da tomada de decisões em relação às questões que lhes dizem respeito, uma vez que "ningún proceso de transformación radical y reduccionista de la realidad carcelaria puede ser afrontado si no atiende a las demandas de los portadores de reclamos" (2009: 472)

Para dar cabo a transformações profundas na instituição prisional, é necessário mudar os processos de formação dos operadores sociais penitenciários e extra-penitenciários. Nesse sentido, a universidade constitui um elemento chave na produção de "conhecimentos não contaminados" pelos centros de formação vinculados com as administrações penitenciárias" (Beiras, 2009: 486).

\footnotetext{
${ }^{96}$ Durante meu estágio sanduiche em Barcelona, encontrei no OSPDH importantes interlocutores para a minha pesquisa. Conheci diversos professores e colegas nas atividades promovidas pelo OSPDH, principalmente nas aulas da Pós-Graduação em Criminologia da UB e em seminários e encontros para comemoração e balanço em torno dos dez anos de existência do grupo, completados em 2011.
}

${ }^{97}$ Analisado nos Capítulos 4 e 5. 
Beiras (2009: 474) propõe a transformação radical e reducionista do uso do cárcere, não a partir de um modelo fechado, mas sintonizado com contribuições teóricas e empíricas, que devem abranger:

- desenvolvimento prévio de uma investigação sociológica da realidade carcerária;

- constituição de comissões representativas dos afetados pela prisão (presos, familiares, operadores jurídicos, representantes de bairros, associação de vizinhos);

- conscientização das limitações dessa opção programática, que exerce um papel reduzido, principalmente se não acompanhada de uma profunda transformação das políticas sociais e penais do Estado;

- partida de um marco jurídico garantista, vinculado ao princípio de legalidade em sede de execução penal, que pressupõe:

- defesa técnica e gratuita;

- decisões judicializadas;

- o reconhecimento dos atuais "benefícios penitenciários" enquanto direitos subjetivos do recluso, a serem determinados a partir de critérios estritamente objetivos da execução penal;

- tomada de medidas urgentes para redução do emprisionamento e redução quantitativa da população presa;

- luta pelo desencarceramento de presos doentes com vista ao seu tratamento ambulatorial adequado e de presas com filhos nas prisões;

- atenção à arquitetura penitenciária e metas reintegradoras seguindo a meta de abolir o isolamento celular, sempre direcionado a tarefa de incapacitação e neutralização do preso.

- promoção de campanhas para sensibilizar a opinião publica no sentido de oposição aos regimes disciplinares especiais ${ }^{98}$, à construção de macro-cárceres e aos centros penitenciários alijados da cidade (política que reforça a invisibilidade da instituição penitenciaria e dificulta a manutenção da relação familiar e social dos presos)

- transformação radical dos programas e das práticas de atuação dos operadores penitenciários de enfoque positivista, filiados a uma ideologia correcional e de tratamento.

\footnotetext{
${ }^{98}$ Que na Espanha se dá pela inclusão do preso no FIES (Fichero de Internos de Especial Seguimientoo)
} 
Segundo Beiras, em relatório acerca das condição penitenciária na Catalunha (OSPDH, 2004: 315), a universidade pode entrar na prisão com os seguintes objetivos: capacitar a população reclusa, promovendo uma diversificação do acesso â cultura e dos bens culturais oferecidos aos presos; construir espaços livres no interior da prisão, onde possam ser reproduzidas a dinâmica universitária sem a vigilância dos funcionários penitenciários; e possibilitar a saída de presos para assistirem aulas na Universidade.

Tais objetivos devem ser perseguidos a partir de um projeto inspirado por uma vontade de mudança radical e humanista, que se negue a função reformista de dirigir-se à simples melhora das condições de cumprimento de pena. Dentro desta perspectiva, qualquer ação deve-se ancorar na certeza de que o problema do cárcere não se resolve no cárcere, mas no seu exterior. Sem essa perspectiva, há o risco de persistir em ações reformistas, que acabam por legitimar a instituição penitenciária, contribuindo assim para sua perpetuidade (Beiras, 2009: 472). 


\section{CAPÍTULO 4}

\section{METODOLOGIA E LINHAS DE ANÁLISE DO CAMPO}

Neste capítulo, que encerra a Parte I desta tese, explicitarei a metodologia de pesquisa e linhas de análise de campo que deram forma aos próximos quatro capítulos, que compõem as Partes II e III.

De início, demarcarei o ponto de partida e os marcos para delimitação do campo de pesquisa. Em seguida, explicitarei as etapas de pesquisa de campo, assim como o método e roteiros de entrevista. Ao final, apresento algumas linhas de análise que me guiaram no recorte e análise do material, assim como referenciais teóricos que contribuíram para a compreensão e interpretação da realidade estudada.

\subsection{Ponto de partida: marcos biográficos}

Ainda que a presente tese não seja um trabalho de antropologia, não pude evitar que esse saber me impregnasse com "certo estado de ânimo", principalmente no que diz respeito à dimensão pessoal e ética do trabalho de campo.

Da aproximação com o "modo de fazer" da antropologia, por meio do contato com etnografias e da inserção em um contexto antropológico em Barcelona, ficaram duas importantes lições. A primeira é a influência da biografia e trajetória pessoal do pesquisador na escolha e trato do seu objeto, e logo, a importância do reconhecimento da subjetividade do investigador na produção da pesquisa. A segunda diz respeito às possibilidades de interações e reflexões sobre os binômios do estranho e do familiar, do distanciamento e da proximidade, que caracterizam a relação do antropólogo e seu campo de estudo.

Escolhi estudar as ações da sociedade civil na prisão sob a ótica do voluntário, ou seja, a partir das entidades de fora que propõe a intervenção. Essa escolha atendeu a dois objetivos: 1) deslocar o lugar de fala do preso de objeto de exame para examinador, ao propor-lhe avaliar o voluntário e a prisão, invertendo a lógica do cárcere; 2) provocar o voluntário acerca das minhas próprias indagações e angústias, para depois voltar às minhas reflexões acerca da minha ação como voluntária. 
Um dos exercícios do fazer antropológico está no reconhecimento do outro em si. No caso da presente pesquisa, eu me identifico com o outro que estudo, o "nativo" e seu universo me são familiares. Por isso, o exercício de me deslocar para outro país e para outro registro disciplinar foi essencial para que eu me descolasse das minhas práticas, desconfiasse das minhas crenças, e passasse a estranhar o que me era familiar.

O contato com meu orientador na Universitat de Barcelona, o antropólogo Manuel Delgado, aproximou-me do que ele denominava "estado de ânimo da antropologia". O modo de fazer antropológico ou a ética etnográfica impregnou não só as reflexões ${ }^{99}$ advindas durante o estágio no Departamento de Antropologia, mas o modo de olhar e reconstruir meu objeto de pesquisa.

A começar pela dimensão confessional do trabalho do antropólogo. Uma das poucas exigências feitas por Manuel, em relação a minha pesquisa, era que minhas motivações pessoais para estudar a prisão estivessem expostas na tese, e que eu ousasse assumir uma confissão compartilhada com ele na nossa última reunião de orientação. Ele me questionou de onde vinha essa "minha vontade de libertar o outro", lhe contei então um acontecimento da minha vida pessoal, a qual havia a pouco associado às minhas escolhas profissionais, 0 qual passo a narrar.

Quando eu tinha 5 anos contraí o vírus da Meningite C (o tipo mais grave da doença). Por se tratar de uma doença infectocontagiosa tive de ficar internada no hospital em caráter de isolamento por uma semana. As enfermeiras e médicos que interagiam comigo, o faziam por meio de máscaras e luvas e por alguns dias me lembro de ter uma companheirinha de quarto, que devia padecer do mesmo contágio que eu.

Dentre as minhas lembranças, talvez as mais antigas e dolorosas que carrego, estão a rotina monótona, a comida insossa do hospital, o quarto branco e frio; mas, principalmente a dor do isolamento representado pela imagem de minha mãe na porta do quarto, detrás da janela de vidro, impedida de entrar pelo risco de contaminação.

\footnotetext{
${ }^{99}$ Parte II da Tese, composta pelos Capítulos 5 e 6 .
} 
As proximidades entre hospital e prisão há muito tempo vêm sendo apontadas pela literatura ${ }^{100}$. Porém, na minha experiência pessoal, essa aproximação se deu antes de eu ter capacidade, intelectual e emocional, para associar conscientemente minha vivência de infância no hospital com as escolhas profissionais relacionadas à prisão.

Hoje, percebo que lutar contra a segregação da prisão e assumir uma postura compreensiva e solidária em relação aos internos, é uma forma de dar voz àquela frágil menina de cinco anos que sentiu desde cedo a violência e as dores do isolamento, sem que tivesse ferramentas para lidar com elas.

Se essa vivência da infância foi determinante na escolha dos temas de pesquisa, a experiência de cinco anos de trabalho em grupo no cárcere (GDUCC) pautaram as escolhas teóricas e metodológicas que fiz ao longo da tese. De 2006 a 2011 acumulei uma série de reflexões e estabeleci pressupostos que fundavam o modelo (que eu supunha ideal) de ação no espaço prisional, a partir dos quais olho e construo minha problemática.

A realidade é vista, descrita e compreendida somente por indivíduos situados historicamente, nascidos em determinada sociedade, região, época e família. E, considerando que esses elementos são fundamentais desde a escolha do tema da pesquisa e até da leitura que fazemos do mundo, passando pelos diálogos que estabelecemos com as pessoas e com as teorias. Cabe ao pesquisador explicitar, desde o início, de onde ele parte, assumindo seus preconceitos, limitações, simpatias e tendências.

Portanto, a leitura que fiz do material bruto, assim como os recortes de campo, os critérios de seleção dos projetos e as perguntas que guiaram a presente pesquisa, passam pelo viés de minha experiência pessoal. Busquei grupos com os quais poderia dialogar desde a minha experiência, e meus questionamentos foram fruto das minhas inquietações e dúvidas frente às minhas proposições práticas e teóricas de ação no cárcere.

Logo, dois marcos na minha biografia são essenciais para compreender o ponto de partida da presente tese: 1) A minha experiência de internação na infância, que ainda que de forma inconsciente, motivou não só a presente pesquisa, mas de diversos encaminhamentos na

\footnotetext{
${ }^{100}$ Foucault os reuniu sob o nome instituições de seqüestro e Goffman instituições totais.
} 
minha carreira; 2) A experiência de cocoordenação do GDUCC de onde notadamente nasceu a necessidade de dialogar com grupos e pessoas que estavam, tal como eu, empenhando uma ação no cárcere.

\subsection{Metodologia da pesquisa empírica}

A metodologia utilizada na coleta de dados do campo da presente pesquisa, apresentados na II e III parte da presente tese, foi qualitativa e abrangeu entrevistas semiestruturadas, análise documental, e relatos etnográficos.

Do ponto de vista metodológico, a pesquisa de campo possibilitou uma abertura importante à minha análise geral. A escolha de ir além de uma abordagem puramente teórica para a construção do objeto de estudo, adveio do conhecimento técnico (e afetivo) do trabalho de campo, somado à percepção de que uma contribuição para a criminologia pode vir por meio da compreensão de uma realidade específica e concreta, ou seja, a partir de pesquisas empíricas no campo prisional.

A metodologia qualitativa tenta capturar a vida social tal como experimentada pelos participantes, e não se limita às hipóteses preformuladas pelo pesquisador ou às categorias analíticas por ele criadas. Assim, o desenho da pesquisa molda-se com o desenvolvimento da própria pesquisa, e a coleta de dados interfere diretamente na maneira de interpretá-los.

A minha experiência na coordenação de um projeto de reintegração social (GDUCC) agregou conhecimentos relevantes para a elaboração e execução da presente pesquisa. Primeiro, a familiaridade com o modo de funcionamento de alguns estabelecimentos prisionais me ajudou a pensar estratégias de pesquisa nesse terreno; e depois, por ter vivenciado as dificuldades práticas de entrar e estabelecer relações no ambiente prisional

\subsection{Marcos temporais e espaciais}

A presente pesquisa foi realizada entre os anos 2009 e 2011, e abrangeu algumas ações da sociedade civil no Estado de São Paulo e na Comunidade Autônoma da Catalunha (Espanha). 
A Parte II, composta pelos Capítulos 5 e 6, foi fruto de investigação realizada na Catalunha, entre setembro de 2010 e junho de 2011, período em que gozei de bolsa de doutorado sanduíche ${ }^{101}$ junto ao Departamento de Antropologia na Universitat de Barcelona.

Já na Parte III, abordei algumas ações no campo prisional de São Paulo. Durante o primeiro semestre de 2010 e o segundo de 2011 investiguei algumas ações relevantes da sociedade civil no Estado de São Paulo, retratando-as no Capítulo 7. Já no Capítulo 8, detive-me especificamente na análise do GDUCC, grupo que ajudei a fundar em 2006 e que atualmente segue com suas atividades em duas penitenciárias do Estado.

\subsection{Etapas da pesquisa nos campos: pesquisa exploratória, seleção dos projetos e pesquisa empírica}

A pesquisa de campo se desenvolveu em três etapas. A primeira consistiu em um levantamento exploratório dos trabalhos que vem sendo realizados em estabelecimentos prisionais (paulistas e catalães), e de informações relacionadas à reintegração do preso.

$\mathrm{Na}$ segunda, foram selecionados, dentro desse universo, os projetos que comporiam efetivamente o campo de análise da presente pesquisa. E, a terceira consistiu na pesquisa empírica, e posterior análise comparativa e reflexiva dessas experiências.

\subsubsection{Primeira etapa: pesquisa exploratória}

De início, realizei uma pesquisa exploratória (por meio da internet) com o objetivo de fazer um breve mapeamento das ações inovadoras de reintegração social no Estado de São Paulo. Dois foram os caminhos da pesquisa na internet: a) a ferramenta de busca (Google) com as palavras "reintegração social", sociedade civil + prisão, ressocialização, entre outras combinações; b) em sites de instituições reconhecidas por sua atuação (institucional ou não) no campo penitenciário.

$\mathrm{Na}$ Catalunha, além da pesquisa na internet, solicitei informações ao Departamento de Justiça, que me disponibilizou uma lista com 21 entidades voluntárias ou colaboradoras

\footnotetext{
${ }^{101}$ Concedida pela CAPES em convênio com a Fundación Carolina.
} 
que atuavam no sistema prisional. Esta lista serviu de guia para a pesquisa na internet, e posterior seleção das entidades que comporiam o campo.

Alguns dos projetos/grupos apresentados na pesquisa exploratória seguiram caminho contrário. Tomei conhecimento deles na literatura especializada, no contato com as pessoas do meio ou pela minha experiência profissional, e depois, busquei a referência na internet.

Além disso, no primeiro semestre de 2009, trabalhei enquanto colaboradora em uma consultoria $^{102}$ encomendada pelo Departamento Penitenciário Nacional, que tinha por objeto um estudo comparativo (nacional e internacional) de boas práticas no sistema penitenciário.

Demandou-se dos Estados, por meio de contatos junto aos órgãos estatais encarregados da Administração Penitenciária, informações sobre "práticas exitosas nas áreas de assistência jurídica, religiosa, de saúde, material, psicológica, social, trabalho, estudo, enfim, todas as assistências previstas como direitos ao preso na LEP, incluindo a visita íntima e assistência e acompanhamento das famílias". Apesar do baixo índice de retorno- somente quatro Estados responderam à solicitação da Consultoria (São Paulo, Acre, Pernambuco, Alagoas)- a participação nessa pesquisa possibilitou o início da exploração do campo de meu objeto de doutorado; principalmente na busca por outras fontes de dados prisionais.

Os resultados das pesquisas exploratórias ${ }^{103}$ relativas ao campo paulista, encontram-se anexos à presente tese. Ali estão resumidas não só experiências compreendidas no universo

102 Estudo comparativo dos modelos nacionais e internacionais, e consolidação de conceitos e práticas de gestão de tratamento penitenciário, em consonância com as normas legais. Projeto PNUD BRA05/038 Modernização do Sistema Penitenciário Nacional, 2009. Consultora Responsável: Maria Emília Nobre Bretan.

${ }^{103}$ A atenção para a forma de apresentação da pesquisa exploratória- assim como alguns cuidados metodológicos- foram tomados a partir das observações e contribuições da Profa. Ana Lúcia Pastore Schritzmeyer, durante a apresentação do projeto em uma das reuniões do NADIR. Ela gentilmente compartilhou o relatório final de uma pesquisa sob sua coordenação, que tinha por escopo fazer um levantamento de experiências bem sucedidas, promovidas pelo Estado brasileiro entre janeiro de 1992 e dezembro de 2002, e consideradas inovadoras na forma de reduzir impunidades e violências cometidas por agentes estatais contra crianças e adolescentes: Mapeamento e Análise de Experiências e Boas Práticas de Redução da Impunidade e da Violência Institucional contra Crianças e Adolescentes. NEV- SP, Núcleo de Estudos da Violência/ Programa de Cooperação UNICEF/BRASIL "Fazendo Valer os Direitos". 
da presente pesquisa, mas também fontes de informações sobre o universo prisional e alguns projetos interessantes em nível nacional.

\subsubsection{Segunda etapa: seleção dos projetos}

A partir da pesquisa exploratória- e da participação na consultoria, foram reunidas uma série de informações acerca de projetos realizados nos cárceres do Brasil, e alguns no exterior. Dentre os quais, quatro projetos paulistas e quatro catalães (além do GDUCC) foram selecionados para serem analisados em profundidade. Foram basicamente três os critérios de seleção: natureza do projeto; localidade em que foi implementado; e, o período em que se desenvolveu.

o primeiro critério para essa seleção foi "a natureza do projeto". Foram priorizados os projetos de iniciativa da sociedade civil (com ou sem convênio/ parceria com o Estado) que propunham uma interação com o cárcere que escape das formas e temáticas tradicionais das ações (tais como aula-curso ou educação formaltrabalho) e que se aproximem dos pressupostos de reintegração social adotados nessa pesquisa ${ }^{104}$.

um segundo critério foi a localidade de desenvolvimento do projeto. Ainda que, na pesquisa exploratória, nos deparamos com projetos interessantíssimos realizados por outros Estados da Federação, e em outros países e comunidades europeias, foram selecionados somente projetos realizados no Estado de São Paulo e na Catalunha, em razão da facilidade de logística para realização das entrevistas, e eventuais observações etnográficas.

o terceiro critério foi o marco temporal. Foram analisados projetos ${ }^{105}$ que estavam ativos nos anos que abrangem o período desta pesquisa, ou seja, entre 2009 e 2011. Esse marco foi uma forma de limitar o universo de estudo à contemporaneidade, $\mathrm{e}$ ao mesmo tempo, privilegiar a observação in loco dos trabalhos e facilitar o contato com os envolvidos com os projetos.

\footnotetext{
${ }^{104}$ Explicitado em profundidade no Capítulo 1.

${ }^{105} \mathrm{O}$ projeto Abrir la cárcel teve sua única edição no segundo semestre de 1999, mas devido a sua importância histórica e a proximidade com o limite temporal predeterminado, optei por incluí-lo no campo de análise.
} 
Além desses, alguns outros fatores ${ }^{106}$ foram levados em conta:

> replicabilidade da experiência em outras conjunturas com circunstâncias geográficas e materiais semelhantes;

> institucionalização da prática (não personalismo): o projeto ou programa não deve depender necessariamente de uma pessoa ou circunstância específicas nem de regionalidades ou particularidades locais para seu desenvolvimento;

$>$ financiamento e sustentabilidade;

$>$ mobilização da sociedade civil e atuação em rede;

$>$ caráter inovador da iniciativa;

\subsubsection{Terceira etapa: pesquisa empírica}

Para vislumbrar que tipo de trabalho vem sendo realizado nos estabelecimentos prisionais paulistas e qual sua orientação teórica, entrevistei coordenadores-executores dos projetos selecionados, assim como presos e pessoas da sociedade civil que participam ou participaram do projeto, e, quando me foi permitido o acesso, acompanhei alguns momentos da execução do projeto no espaço prisional, produzindo relatos etnográficos dessas experiências.

Além disso, realizei análise documental dos memoriais, projetos, conteúdos de sites, relatórios, pesquisas acerca das ações da sociedade civil no cárcere. Os documentos foram obtidos a partir de pesquisas na internet e bibliotecas especializadas, e em resposta às solicitações as entidades da sociedade civil e instituições públicas ligadas à questão prisional.

\subsection{Técnica e roteiros das entrevistas}

Busquei entrevistar no mínimo oito pessoas relacionadas a cada projeto: dois membros da sociedade civil participantes, dois presos participantes, um preso não-participante, o coordenador ou outro que responda pelo projeto, o diretor do estabelecimento penitenciário, e, ao menos um funcionário do estabelecimento prisional onde o projeto é realizado.

\footnotetext{
${ }^{106}$ Inspirados no Guia de Avaliação da $3^{\text {a }}$ Edição do Prêmio Sócio-Educando (2008), da qual compus o Conselho Consultivo da categoria "Execução de medidas socioeducativas em meio fechado".
} 
Nas entrevistas, abordei três temas centrais: 1. informações sobre o projeto (objetivos, bases teóricas e dificuldades); 2. a prática da reintegração social - como ocorre a interação entre sociedade civil e presos (estratégias e métodos); 3. o impacto do projeto na vida das pessoas e instituições envolvidas.

Optei pelo modelo semiestruturado de entrevista, que permitiu focar nos assuntos que me interessavam, e ao mesmo tempo, deixar espaço para que meus interlocutores falassem o que julgavam importante. Essa técnica possibilitou ainda, que outras temáticas conexas aparecessem na fala dos entrevistados e fossem agregadas aos roteiros de entrevista no decorrer da pesquisa.

Em algumas entrevistas fiz uso de gravador, porém, na maioria delas abri mão desse recurso ao notar o constrangimento e perda de espontaneidade dos meus interlocutores frente ao aparelho. Certamente, há uma grande diferença na precisão dos dados colhidos com o gravador, principalmente no tocante à transcrição de expressões utilizadas pelo entrevistado. A gravação constitui uma prova do que foi dito. O uso do gravador, principalmente em ambientes prisionais, é mais um obstáculo à conquista da confiança do entrevistado, e à verbalização de certos temas (normalmente, de discursos abafados pela prisão e por outros presos).

Logo, o porte de um gravador nas entrevistas realizadas na prisão não facilitaria a minha entrada. Quando a negociação estava difícil, eu sequer mencionava essa possibilidade. Em compensação, nesses anos de pesquisa, acumulei uma dezena de cadernos de campo, que contém entrevistas, impressões e os relatos de inúmeras idas ao cárcere.

Algumas das entrevistas iniciais desta pesquisa, realizadas no primeiro semestre de 2010, foram feitas com gravador. Isso estará indicado no decorrer do texto, devido à diferença na forma de registro da entrevista. Todas as demais foram transcritas nos cadernos de campo, a partir do roteiro de entrevista.

Todas as pessoas entrevistadas autorizaram o uso das informações nesta pesquisa, mediante a assinatura do "termo de consentimento livre e esclarecido". Ainda assim, a 
identidade dos entrevistados foi preservada pelo uso de pseudônimos, com exceção dos pesquisadores e professores que colaboraram com a presente tese.

Temáticas ligadas a vida pessoal dos interlocutores não foram objeto das entrevistas. Durante as conversas, concentrei-me na problemática da interação social entre prisão e sociedade livre, evitando quaisquer questionamentos de cunho pessoal que implicassem a exposição do meu interlocutor, e consequentemente, pudessem comprometer a ética da minha pesquisa.

Elaborei cinco roteiros de entrevista: começando por um núcleo comum a todos os entrevistados, seguido de quatro específicos, voltados a: o coordenador do projeto, membros da sociedade civil participantes, presos participantes e não participantes, diretor do presídio/ funcionário da instituição prisional.

A fase de elaboração dos roteiros foi importante para refletir quais eram as minhas indagações. Porém, a minha experiência no campo mostrou que a entrevista fluía melhor quando mais solta, quando se deixa o entrevistado conduzi-la a partir de sua perspectiva, dizer o que acha importante ser dito. Portanto, a tendência adotada nas entrevistas, foi o uso do roteiro apenas como um norte, privilegiando assim uma abordagem menos dirigida.

Esse tipo de abordagem mais flexível, mostrou-se uma estratégia para se chegar nas concepções mais sutis melhor do que a pergunta direta- estratégia utilizada nas primeiras entrevistas. A flexibilidade é importante, levando-se em conta a diversidade dos tipos de interação estabelecida em cada entrevista: as pessoas entrevistadas têm histórias e formações diferentes, o local e as representações sociais em jogo são também muito distintos.

\subsubsection{Roteiro básico de entrevista (núcleo comum a todos os entrevistados)}

- Qualificação do entrevistado: nome, idade, formação, profissão, relação com o projeto e com o sistema prisional. Como você se definiria?

- Primeiramente, o que você tem vontade de me contar sobre o projeto?

- Quais as maiores dificuldades na realização do projeto?

- Você consegue notar alguma mudança nos participantes com esse trabalho? 


\subsubsection{Roteiro específico: coordenador do projeto}

- Como foi o seu envolvimento? Quais eram suas expectativas no início do trabalho? Elas foram cumpridas?

- Como nasceu o projeto?

- Qual o objetivo da intervenção?

- A intervenção tem alguma base teórica?

- Como é a relação do grupo com os funcionários penitenciários?

- Como são selecionados os presos que participarão?

- De que forma as pessoas da sociedade civil foram atraídas pelo projeto? Há alguma forma de seleção?

- Como foi sua entrada na prisão? Quais foram as surpresas e dificuldades?

- Como é a dinâmica dos encontros? Você poderia descrever um deles?

\subsubsection{Roteiro específico: membros da sociedade civil participantes}

- Por que você resolveu participar do projeto?

- Como é a sua relação com os presos?

- Como é a sua relação com os funcionários da prisão?

- Como seus familiares e amigos enxergam esse seu trabalho?

- Como é a dinâmica dos encontros? Você poderia descrever um deles?

\subsubsection{Roteiro específico: presos participantes}

- Por que você resolveu participar do projeto?

- Você já participou de outros projetos aqui na prisão? O que achou?

- Qual impressão que você tem dos participantes que vem de fora? Porque você acha que eles vem até aqui fazer esse trabalho com vocês?

- Como é a dinâmica dos encontros? Você poderia descrever um deles?

- Se você tivesse que propor uma ação da sociedade na prisão, o que você faria?

\subsubsection{Roteiro específico: presos não participantes}

- Você já ouviu falar do projeto? O que você ouviu falar?

- Tem vontade de participar?

- Você já participou de projetos como esse aqui na prisão? O que achou?

- Se você tivesse que propor uma ação da sociedade na prisão, o que você faria? 


\subsubsection{Roteiro específico: diretor do presídio/ funcionário da instituição prisional}

- Como você tomou conhecimento do projeto? Você se envolve direta ou indiretamente com as ações propostas?

- Foi preciso readequar a dinâmica da prisão por conta das pessoas que veem de fora?

- Existem outros projetos desse tipo sendo desenvolvidos nessa prisão?

- Como são selecionados os presos que participarão?

- Você consegue notar algum impacto na prisão com esse trabalho?

\subsection{Linhas de análise do campo}

Estabeleci algumas linhas para a análise do vasto material que colhi ao longo dos três anos desta pesquisa, consciente dos limites de qualquer categorização frente à complexidade da realidade estudada.

Apesar dessas linhas terem guiado a leitura e seleção dos dados do campo, tentei que as reflexões desta tese não se reduzissem a tais classificações. Primeiro, porque as minhas categorias de análise não necessariamente estavam respaldadas no discurso dos meus interlocutores. Logo, percebi ${ }^{107}$ que precisaria dar espaço para que outras leituras aparecessem representadas na tese. Em segundo lugar, porque os dados foram colhidos em contextos e condições específicas, dando origem a materiais com forma e conteúdo bem distintos entre si, afastando a possibilidade de comparação direta e reducionista entre os grupos.

A dinâmica de cada estabelecimento prisional é única, conformada a partir do lugar, tipo de instituição, pessoal penitenciário, perfil do preso, e contingências políticas da época. Além disso, as formas de produção de dados da pesquisa empírica sofreram grandes variações e adaptações de um grupo para outro, em um processo permanente e circular na pesquisa, entre a observação do campo e a construção de suas representações.

Diante da impossibilidade de se extrair da análise uma conclusão generalizante ou um modelo ideal que sintetizasse a diversidade de entidades e seus contextos históricos e

\footnotetext{
${ }^{107}$ Tal percepção fez com que eu relativizasse e repensasse os meus questionamentos diversas vezes durante a coleta de dados e construção do texto.
} 
sociais, as linhas de análise propostas e as comparações entre as entidades devem ser lidas à luz da singularidade dos casos concretos.

As nove linhas que passo apresentar atenderam a três objetivos principais:

\section{Situar a ação das entidades e os voluntários no seu contexto histórico-social}

4.6.1. História das entidades, objetivos, contexto de atuação e perfil do voluntário

4.6.2. Biografia do entrevistado

II. Compreender como a entidade se relaciona com os outros atores do campo prisional, seu grau de autonomia e o diálogo que mantém com eles

4.6.3. Relação com a instituição prisional e com órgãos da burocracia estatal

4.6.4. Autoria das propostas e autonomia na execução dos projetos

4.6.5. Representações dos presos pelos voluntários e representações dos voluntários pelos presos

III. Investigar motivações dos participantes, a natureza das atividades e o impacto das ações no cárcere e na sociedade

4.6.6. Natureza da atividade proposta

4.6.7. Motivações primárias e secundárias dos voluntários e presos participantes dos projetos

4.6.8. Impacto das ações no cárcere, na sociedade e nas pessoas diretamente envolvidas com os projetos

4.6.9. Ressocialização x reintegração

\subsubsection{História das entidades, contexto de atuação e perfil do voluntariado}

O primeiro cuidado que tive antes de aprofundar a análise das ações realizadas no cárcere foi o de reunir informações acerca da entidade que as propunham. Para tanto, realizei uma pesquisa exploratória acerca da origem e história das entidades, histórico de projetos, contexto de atuação, objetivos, perfil do voluntário etc.

O conhecimento do histórico, do contexto social e do perfil das entidades ajudou tanto na compreensão das ações e escolhas do grupo quanto na reflexão acerca das condições históricas e sociais que possibilitam o nascimento desse tipo de prática e discurso. 


\subsubsection{Biografia do entrevistado}

Tentei significar as falas a partir da história de vida dos meus interlocutores. Importava-me compreender como o voluntário significava o cárcere na sua vida, quando e porque se deu essa aproximação.

Obtive uma percepção mais apurada dessas informações biográficas, não no ambiente de entrevista, mas em conversas informais com os meus interlocutores; nesse sentido, foi importante compartilhar caronas, cafés, trens de metrô, seminários, enfim, experiências cotidianas que faziam frente à exceção do cárcere.

O equilíbrio entre o respeito à especificidade de cada fala, por um lado, e, a necessidade de generalizações e categorizações para a construção de uma teoria, por outro, foi um dos grandes desafios enfrentados na análise do campo. Por mais que tenha tentado me desprender dos meus valores e crenças para compreender os discursos a partir do lugar de fala do outro, tenho consciência do quanto minha biografia e crenças consolidadas a respeito do meu objeto de pesquisa impregnaram a análise que proponho.

\subsubsection{Relação com a instituição prisional e a burocracia estatal}

Importou saber também quais as redes em que os grupos estavam inseridos, ou seja, como eles se relacionavam com o poder estatal, pessoal penitenciário, demais entidades, presos etc. Esse aspecto foi importante para pensar as possibilidades de atuação em conjunto e nas relações que perpassam um trabalho como esse.

\subsubsection{Autoria das propostas de ação da sociedade civil}

Foi importante ainda identificar a autoria das ações que os grupos realizavam. Um dos pressupostos que caracterizam a "reintegração social" é o de que cada ator assuma sua responsabilidade na execução penal e atue desde o seu lugar social. Logo, ao entrar no cárcere, uma entidade deve propor ações condizentes com o interesse e particularidades daquele grupo social especifico.

A possibilidade da reintegração social relativiza o tradicional fechamento imposto pelo cárcere. Portanto, quanto maior a diversidade de atores e de atividades no cárcere, menor o 
monopólio institucional das relações sociais travadas nesse espaço, e consequentemente, menor a exposição do indivíduo ao processo de prisionização.

Na medida em que a prisão abre-se para a entrada da sociedade civil, mas determina as formas de atuação da mesma, somente um degrau para a reintegração foi alcançado. A permeabilidade do cárcere às pessoas de fora deve ser ampliada tanto quantitativa quanto qualitativamente. A instituição prisional deve abrir-se para a entrada do maior número possível de pessoas e grupos da sociedade, e ao mesmo tempo, dar a esses atores e aos próprios presos alguma autonomia.

Quando o próprio cárcere pauta as atividades da sociedade civil que acontecem no seu interior, pouco se alcançou em termos de reintegração social; portanto, o grau de ingerência do sistema prisional, assim como o grau de liberdade do grupo na proposição e execução de suas atividades, são informações essenciais para a reflexão acerca da potência dessas ações.

\subsubsection{Representações dos presos pelos voluntários e representações dos voluntários pelos presos}

Os projetos da sociedade civil no cárcere propiciam a aproximação de dois grupos claramente definidos: os presos e os "representantes da sociedade livre". Em torno desses dois grupos gravitam uma série de representações sociais, estereótipos e expectativas que serão determinantes na forma de interação social que se estabelecerá entre eles.

Logo, outra fonte de informação que identifiquei relevante para a análise foram as impressões de um grupo sobre o outro, e as mudanças nessas percepções com o desenrolar da interação social.

\subsubsection{Motivações primárias e secundárias dos voluntários e presos participantes dos projetos}

As motivações dos voluntários e presos participantes nos projetos da sociedade no cárcere revelam o sentido que estas ações assumem para seus participantes, e as transformações deste sentido, de acordo com o grau de envolvimento com a proposta. 
Nesse sentido, dividi as motivações entre primárias e secundárias. As primárias corresponderiam às motivações dos indivíduos antes do início das atividades, e as secundárias seriam decorrentes da permanência do indivíduo na atividade depois de vivenciadas as primeiras expectativas.

\subsubsection{Impacto das ações no cárcere, na sociedade e nas pessoas diretamente envolvidas com os projetos}

A ação da sociedade civil no cárcere afeta tanto os atores envolvidos diretamente na atividade (voluntário e preso) quanto o entorno em que eles se encontram (sociedade livre e prisão). Interessou-me investigar a percepção desses atores quanto às mudanças, pessoais e sociais, acarretadas pelos projetos da sociedade civil no cárcere.

Ainda que em diferentes formas e graus, a presença da sociedade no cárcere tem o condão de impactar as sensibilidades individuais e sociais. De forma geral, a experiência no cárcere acarreta na forma do voluntário perceber o preso e a prisão mudanças que se propagam para seu entorno social. Essa experiência é marcante para o membro da sociedade civil envolvido, pois, apesar da ampla cobertura midiática das questões criminais e prisionais, o contato pessoal com o sistema prisional é uma exceção na vida dos voluntários.

Já o impacto das ações da sociedade civil na dinâmica prisional como um todo parece ser mais reduzido. O sistema prisional, em maior ou menor grau, sempre foi permeado pela presença de membros da sociedade. Logo, a presença de um grupo de fora desenvolvendo atividades não chega a ser novidade. Ademais, muitas das atividades propostas pelos voluntários se aproximam das atividades recorrentes do cárcere promovidas pelos técnicos do sistema. Logo, apesar da ação da sociedade civil dificilmente afetar a dinâmica prisional como um todo, ela afeta os presos envolvidos e as relações sociais em torno de um espaço especifico.

\subsubsection{Tipo de atividade proposta}

Outro critério de diferenciação dos grupos estudados foi o tipo de atividade realizada. Conforme explicitado nos capítulos anteriores, a sociedade civil, ao entrar no cárcere, exerce uma importante função de comunicar o mundo de dentro com o de fora, e impactar 
a dinâmica prisional; porém, o sucesso dessa empreitada está condicionado ao tipo de atividade realizada.

A partir dos pressupostos teóricos da reintegração social, a sociedade deve entrar no cárcere para realizar o "papel de sociedade", ou seja, propiciar experiências de diálogo e reflexão, aproximando o universo prisional da sociedade livre, e vice versa. Quando a sociedade civil assume funções no cárcere que originalmente seriam de responsabilidade do Estado, suas ações se inscrevem no quadro institucional, e ficam comprometidas a autonomia e potência da ação da sociedade na prisão.

\subsubsection{Ressocialização $x$ reintegração}

Umas das linhas centrais de análise das entidades, e talvez a mais complexa, foi a identificação de suas ações como mais próximas à perspectiva de ressocialização ou aos pressupostos de reintegração social ${ }^{108}$, sem reduzi-las a tais significações.

Associei à linha de ressocialização os projetos de abordagem redutora, concentrados na figura do preso, com a finalidade de promover neste uma readequação ética-valorativa. Essas ações, de forma geral, não diferem de outras realizadas por funcionários da instituição prisional. Elas atendem às expectativas institucionais e contribuem para reafirmar o papel do preso na dinâmica prisional enquanto objeto receptor de ideias e valores.

Já as ações identificadas como mais próximas da proposta de reintegração social buscam mudar as formas de relação estabelecidas no cárcere, provocando no preso e no voluntário a assunção de um papel ativo e reflexivo nas suas inter-relações sociais. Esse tipo de ação não é direcionado ao preso, mas situa-se na relação deste com a sociedade livre. Os grupos que propõem essas ações tendem a ter problemas para entrar ou permanecer no sistema, já que, a longo prazo, elas podem (e devem) despertar questionamentos em relação ao modo de fazer do cárcere.

\footnotetext{
${ }^{108}$ Apresentadas no Capítulo 1.
} 


\subsection{Referenciais teóricos}

Nos capítulos teóricos que compõem a Parte I da presente tese, recorri a alguns autores que serviram como referenciais para a elaboração de uma teoria acerca das ações da sociedade civil na prisão.

Para pensar o sentido da pena e da prisão na contemporaneidade, recorri principalmente a Garland (1999), Young (2002), Deleuze (1992), Bauman (1999 e 2000), De Giorgi (2006), Wacquant (2001), Chantraine (2006), Foucault (1995, 2000, 2004, 2006).

Na tarefa de levantar os fundamentos e pressupostos da reintegração social, apropriei-me principalmente das reflexões de Baratta (1990), Beristain (1993, 1998, 2000, 2007), Bobbio (1982, 1987), Cohen (1985), Hulsman (1985, 1993, 2004), Mathiesen (1989, 1997 , 2000), Sá (2007, 2008, 2011) e Zaffaroni (1990, 1991, 1998).

Além dos referenciais acima mencionados, adotei especificamente dois autores para a interpretação dos dados do campo: Michel Foucault e Pierre Bourdieu. Passo a expor alguns conceitos desses autores que serviram de instrumento para a compreensão da realidade estudada.

\subsubsection{Atitude crítica: a influência de Michel Foucault}

O contato com as obras de Michel Foucault foi essencial à minha formação pessoal e acadêmica. Em especial, três noções foucaultianas, intelectual especifico, resistência e atitude crítica, embasaram minhas escolhas metodológicas e os questionamentos propostos nas minhas pesquisas e intervenções.

A presente tese teve a influência, direta e indireta, das concepções teóricas e das propostas metodológicas do filósofo francês. $\mathrm{Na}$ elaboração dos capítulos teóricos, trabalhei diretamente com noções foucaultianas, tais como poder, disciplina, governamentalidade, resistência, etc.

A abordagem foucaultiana dos discursos também teve influência fundamental na coleta e análise das falas dos meus interlocutores. Nesse sentido, tentei analisá-las não sobre o registro de sua validade racional (veracidade-falsidade), mas a partir dos efeitos de poder que produzem. Para além dos discursos, me interessou conhecer as práticas e os 
enunciados produzidos por elas, saber em que medida confirmam um modo de fazer a execução penal e relegitimam verdades acerca da prisão, do crime e da sociedade.

É a partir do funcionamento real das instituições que a racionalidade penal pode ser apreendida, a partir da ação do poder respaldada em determinado discurso. Nesse sentido, não há um lugar "da" racionalidade, não há um parâmetro único para se auferir se uma prática é mais racional que outra. Cada prática é inscrita em uma racionalidade própria, a partir da qual codificará prescrições (regras dirigidas a um fim) e estabelecerá critérios de veracidade e falsidade.

Ademais, o uso do termo crítico (e suas derivações) para classificar os grupos e suas ações na análise de campo obedece ao sentido que Foucault (2000) atribui à atitude crítica ${ }^{109}$. A atitude crítica consiste em uma mudança de relação com o poder, suas práticas e os efeitos de verdade que elas produzem.

Para Foucault (1980: 53), a crítica não é um raciocínio que se conclui em si, mas um instrumento para aqueles que lutam, resistem, não querem mais as coisas do jeito que estão. "O que se deve fazer não deve ser determinado do alto, por um reformador com funções proféticas ou legislativas. Mas por um longo trabalho de vaivém, de trocas, reflexões, tentativas, análises diversas".

$\mathrm{Na}$ época do lançamento de Vigiar e Punir, Foucault foi acusado de que a obra tenha causado um efeito paralisante principalmente entre aqueles que trabalham no sistema penitenciário, já que após a leitura de Foucault, eles não enxergavam qualquer caminho para “melhorar o sistema prisional”. Em uma mesa redonda realizada em $1978^{110}$, Foucault (1980: 42) responde a essa acusação afirmando que o fato dos trabalhadores do cárcere não encontrarem respostas em Vigiar e Punir não significa que eles estejam paralisados. Ao contrário, é prova de que eles desejam achar outros caminhos, e isso já é um grande passo.

\footnotetext{
${ }^{109}$ Mencionado no Capítulo 3, item 3.2.

110 Em 20 de maio de 1978 uma mesa redonda foi organizada com um grupo de historiadores, com objetivo de debaterem acerca da história da prisão e dos sistemas penitenciários do século XIX. A transcrição do debate está publicada na obra l'Impossible prison sob a coordenação de Michelle Perrot (1980).
} 
Um dos objetivos do trabalho de Foucault, do qual compartilho, é contextualizar os acontecimentos e suas rupturas, questionar as evidências, despertando mudanças em modos de perceber e em maneiras de fazer: não permitir que "certas frases não possam ser ditas tão facilmente" ou que certos gestos não possam ser realizados sem hesitação.

Porém, segundo o próprio autor (Foucault, 1980: 53), as pessoas que trabalham no quadro institucional da prisão não devem encontrar nos seus livros um manual de procedimentos, mas justamente o contrário. O projeto de Foucault é justamente "que eles não saibam o que fazer”. Irritante ou não, a verdade é que o pensamento foucaultiano é desestabilizador, no sentido de minar certezas e desnaturalizar práticas arraigadas ao funcionamento das instituições e de nossas sociedades.

Nesse sentido, identifiquei como críticas as ações com vista às reinvenções de possibilidades de vida e de resistência às atuais formas de sujeição do cárcere. Uma atitude crítica pressuporia uma reflexão anterior sobre os modos de fazer da execução penal, ciente do alcance e da consequência de suas práticas não só em uma perspectiva micro, mas em âmbito político, no sentido de contribuir na construção de uma nova política da verdade na política criminal, na forma da sociedade e do indivíduo relacionar-se com o crime e o criminoso.

A experiência da reintegração social, se bem sucedida, propicia formas de interação entre cárcere-sociedade que permitem a produção de novas subjetividades. A atitude crítica em relação aos discursos e práticas carcerárias, desde que produtivas e não só reativas, tem a potência de criar no cárcere algum "espaço de liberdade", uma liberdade possível, tal como descrita por Foucault (1995: 224):

"um estado transitório em que sujeitos individuais ou coletivos tem diante de si um campo de possibilidades de diversas condutas, diversas relações e diversos modos de comportamento que podem acontecer"

A liberdade para Foucault, fruto do exercício da crítica, não é livrar-se de todas as amarras e das ações do poder. Libertar-se é resistir à forma como somos conduzidos, para poder eleger quem irá nos conduzir, como e em que direção; poder escolher outras formas de ser, diferentes das que nos tem sido dadas. 
As matizes da realidade não permitem a ordenação do mundo dentro de dicotomias: crítico ou acrítico, revolucionário ou reformador, poder ou resistência. Na realidade, um contém e se mescla com seu oposto. Inclusive a resistência, para Foucault, não é exterior ao poder ou governo, mas constituinte deles.

\subsubsection{Campo, habitus, capital: contribuições de Bourdieu à análise do campo}

De forma geral, as produções no âmbito da criminologia no Brasil que questionam o funcionamento do sistema de justiça penal respaldam-se teoricamente em um núcleo comum de autores ${ }^{11}$, composto por cientistas sociais, filósofos, juristas e criminólogos. Entre os nomes mais recorrentes nestas produções estão: Foucault, Wacquant, Garland, Bauman, Mathiesen, Hulsman, Baratta, Zaffaroni, etc. São os mesmos que me guiaram na elaboração das proposições teóricas acerca da realidade carcerária e as possibilidades de interação da sociedade civil no espaço prisional presentes nesta tese.

Porém, para a análise do material empírico desta pesquisa, busquei ampliar o arcabouço teórico para além dos autores tradicionalmente estudados em âmbito criminológico.

E foi justamente no contato com a teoria do sociólogo francês Pierre Bourdieu que encontrei alguns conceitos interessantes que permitiam pensar a ação da sociedade civil no cárcere a partir de outra chave. Tentei utilizá-los dentro da proposta de "caixa de ferramentas" de Gilles Deuleze:

"Uma teoria é como uma caixa de ferramentas. Nada tem a ver com o significante... É preciso que sirva, é preciso que funcione. E não para si mesma. Se não há pessoas para utilizá-la, a começar pelo próprio teórico que deixa então de ser teórico, é que ela não vale nada ou que o momento ainda não chegou. Não se refaz uma teoria, fazem-se outras; há outras a serem feitas...A teoria não totaliza; a teoria se multiplica e multiplica"

(Deleuze In.: Os intelectuais e o poder. Foucault, 1979: 71)

Parto do pressuposto que a interação no campo prisional envolve trocas simbólicas que podem ser examinadas à luz das noções-ferramentas de jogo, campo, estratégias, capital cultural, formuladas na teoria de Bourdieu, (2000, 2004, 2004b).

\footnotetext{
${ }^{111}$ Esse "núcleo" funciona apenas a título ilustrativo, adveio da minha percepção acerca das leituras e discussões no meio acadêmico brasileiro; certamente, uma definição precisa desses autores dependeria de uma metodologia apurada de análise.
} 
Bourdieu (2004b:150) situa seu trabalho dentro da tradição sociológica, denominando-o "constructivist structuralism" ou "structuralist constructivism", de estruturas objetivas que orientam práticas e representações, com esquemas de percepção, pensamento e ação (denominados habitus por Bourdieu), e estruturas sociais (campos, grupos, classes sociais).

Bourdieu sintetiza duas correntes opostas a que as teorias sociológicas filiam-se: estruturalismo e construtivismo. Essa síntese permite que se reconheçam as condições históricas e materiais que atuam sobre o objeto estudado (estrutura), sem perder de vista a capacidade de produção e transformação dos agentes sociais inscritos naquela estrutura (construto).

O equilíbrio entre o campo de determinações e o campo de possibilidades é uma chave importante para a análise das situações da sociedade civil no cárcere, porque permite o reconhecimento das estruturas de poder existentes no campo prisional, e ao mesmo tempo, das possibilidades dos agentes disputarem e transformarem tais estruturas.

Esse duplo reconhecimento permite a crítica às atuais estruturas de poder que conformam o cárcere, ao mesmo tempo em que deixa uma abertura no campo para a modificação dessas estruturas. Ainda que as formas de interação social no cárcere estejam inscritas em uma rede de exercício de poder relativamente configurada, o modo de fazer prisional está em constante disputa. Essa leitura permite que se reconheça a potência da sociedade civil para transformar essas estruturas, e abre caminhos às reflexões propostas nesta tese.

A perspectiva bourdiana também contribuiu para que eu me posicionasse conscientemente no campo da dissimetria entre eu e meus interlocutores, tanto no tocante à posição de poder assumida enquanto pesquisadora no estabelecimento das regras e comando do jogo, quanto à própria assimetria social anterior - já que o pesquisador tem maior acesso ao capital, principalmente o cultural, incluindo aqui os bens linguísticos e simbólicos (Bourdieu, 1999: 695).

\footnotetext{
${ }^{112}$ Em tradução livre, corresponderia às expressões "estruturalismo construtivista" ou "construtivismo estruturalista", respectivamente.
} 
Sendo a assimetria intransponível, cabe ao pesquisador reduzir ao mínimo a violência simbólica por ele exercida, instituindo assim o que seria uma comunicação não violenta, partindo do esclarecimento do objeto da pesquisa, seus objetivos, riscos e limitações, e o que o entrevistado entende disso. Para tanto, ainda segundo Bourdieu, o pesquisador precisa ter disponibilidade total em relação ao entrevistado, submetendo-se à singularidade daquela história particular, apreendendo sua linguagem e seus pontos de vistas.

Mobilizo as noções bourdianas de campo, jogo, posições, estratégias, habitus, capital social e poder simbólico, buscando compreender como as pessoas da sociedade civil ocupam e movem posições no jogo da prisão, a partir de que estratégias e em posse de que capitais.

Ainda que faça pouco uso explícito desses conceitos, a leitura do espaço social proposta por Bourdieu foi fundamental para minha interpretação acerca da dinâmica prisional e da ação social no cárcere. A leitura de seus textos também influenciou a escolha dos questionamentos que pautaram o meu trabalho de campo. Percebi o quanto tinha internalizado algumas dessas noções quando, nas conversas com informantes, interrogavaos a respeito de estratégias, posições, trunfos, chegando a compartilhar com eles a ideia de estarmos no "jogo da prisão".

A seguir, proponho um breve recorrido desses conceitos e suas aplicações, diretas ou indiretas, na presente tese.

\section{- Prisão como campo}

O primeiro conceito emprestado da teoria de Bourdieu (2004b: 127) para a presente tese é o conceito de campo, enquanto "espaços de jogo historicamente constituídos, com suas instituições específicas e suas próprias leis de funcionamento". Nesse sentido, proponho pensar a prisão como um "campo de força", um espaço estruturado de posições e de lutas entre agentes que as ocupam, fruto da continência histórica e ao mesmo tempo das batalhas do presente. 
No espaço social bourdiano, os agentes sociais definem-se pelas posições que ocupam: grupos, pessoas ou instituições apresentam qualidades e propriedades distribuídas de maneira desigual, o que faz que tomem posições distintas no campo.

A prisão constitui um campo da esfera da vida social relativamente autônomo, com relações e recursos próprios, e guiada por uma lógica interna em constante relação com o exterior. De tal sorte que a caracterização de Bourdieu (2000: 30) para campo político como um espaço "suficientemente cerrado sobre sí mismo y suficientemente independiente de lo que pasa en el exterior" poderia ser estendida para o campo prisional.

A segregação em relação ao mundo externo é constitutiva da prisão. O fechamento da instituição prisional manifesto não só pelos muros, mas principalmente pela impermeabilidade em relação às influências externas. A prisão evoca o monopólio legítimo da produção de saber em relação ao preso, e guarda uma série de segredos acerca da dinâmica prisional. Isso lhe garante o protagonismo na determinação dos modos de fazer do cárcere, e das formas de interação ali estabelecidas.

De acordo com Bourdieu (2000: 14), o fechamento em relação ao exterior é um índice muito significativo da autonomia de um campo. O campo se torna autônomo na medida em que passa a dispor de seus próprios capitais, estratégias e interesses, a partir dos quais se constituirão as regras de organização e de hierarquização daquele espaço social.

Porém, a constituição de um campo não é determinada por uma estrutura rígida de posições, mas é produto de uma luta: o "campo é um jogo no qual as próprias regras estão em jogo" (Bourdieu, 1996: 29). As representações do mundo social feita pelos seus agentes e a disputa cotidiana de percepções e verdades acerca daquele espaço são também criadoras e recriadoras do campo, nas palavras do autor:

"El espacio social, en efecto, no es solamente un objeto de percepción dentro del cual los individuos o las instituciones estén caracterizadas de manera fija por la combinación de un cierto número de propiedades y por la ocupación de una posición determinada dentro de un sistema de clasificación; es también un juego de luchas entre los agentes por imponer su construcción y su representación del mundo social, sus categorías de percepción y de clasificación, y por ello por actuar sobre el mundo social "

(Bourdieu, 2000: 30) 


\section{- A dinâmica prisional como um jogo}

A ideia de pensar a prisão como um jogo não foi fruto de um exercício analítico, mas surgiu quase intuitivamente a partir da minha percepção e dos meus interlocutores a respeito do cárcere. A disputa de valores e "modos de fazer" no cárcere, suas regras implícitas e explicitas, a posição dos jogadores e a dinamicidade das relações sociais, dão corpo ao sentido de jogo.

As regras do jogo constituem regularidades objetivas que se impõem a todos aqueles que entram na peleja. O conhecimento delas é condição primordial para que o jogador seja introduzido e sobreviva no jogo. Porém, no "jogo social" de Bourdieu, ainda que as regras sejam reconhecidas e interiorizadas pelos agentes, nem sempre elas se encontram explícitas e escritas.

O jogo em Bourdieu funciona sob uma "lógica imanente", determinante da forma de jogar, e que requer do jogador o domínio prático da lógica do jogo e outras habilidades advindas da experiência no jogo.

A estratégia de cada jogador é desenhada a partir da posição que ocupa no jogo. Em geral, os agentes compartilham o interesse na continuidade do campo, ainda que suas estratégias possam ser identificadas como mais próximas à conservação ou à subversão da organização do campo.

Ao eleger o termo estratégia para designar a ação dos jogadores, em detrimento de outras denominações mais rígidas como modelo ou padrão de comportamento, Bourdieu (2004b: 23) situa a problemática do campo no ponto de vista dos agentes, reconhecendo a autonomia dos jogadores em relação à estrutura do campo, sem transformá-los em meros calculadores racionais ou personagens restritos às predefinições de seus papéis sociais.

Segundo Bourdieu, (2004b: 81) a ação do indivíduo não é nem produto inconsciente- da obediência mecânica à regra, nem produto de um cálculo consciente e racional. É produto do senso prático, do "sentido do jogo". Sendo o jogo um sistema aberto e em movimento, estar nele pressupõe uma invenção permanente, e a capacidade de reação perante situações inusitadas: 
"Este 'sentido do jogo', como dizemos em francês, é o que permite gerar uma infinidade de 'lances' adaptados à infinidade de situações possíveis, que nenhuma regra, por complexa que seja, pode prever"

(Bourdieu, 2004: 21)

O sentido do jogo, as habilidades e a legitimidade para jogar, distribuem-se de maneira desigual entre os jogadores. No jogo da prisão, certamente os internos tem menores possibilidades do que os funcionários da instituição.

É comum que as estratégias de auto-organização dos presos sejam deslegitimadas pela instituição prisional sob a acusação que qualquer organização de presos seria literalmente uma "organização criminosa", e, portanto voltada para o crime.

Ademais, como demonstrarei na análise, os presos para ter a possibilidade de conquistar algum "benefício" (saídas temporárias, visitas, remissão da pena) são compelidos a ingressar nesse particular jogo de cooperação com a instituição prisional e "mantener ciertas formas consideradas adaptadas en su relación con la institución” (Zino Torraza, 1996: 631).

\section{- Habitus da prisão}

Outro conceito fundamental da teoria de Bourdieu é o habitus como "tendência para agir de uma maneira regular, mas que não se origina em uma regra ou lei explícita”, consiste em um sistema de disposições inconscientes construído a partir de interiorização de estruturas objetivas, que produz práticas e carreiras ajustadas a essas estruturas (Bourdieu, 2004b: 98).

O habitus aponta caminhos possíveis e práticas potenciais do agente, é "aquello que hace que los agentes dotados del mismo se comporten de cierta manera en ciertas circunstancias" (Bourdieu, 1987b: 40). O habitus é durável à medida que garante certa regularidade às condutas; e flexível e atualizável de acordo com as vivências dos indivíduos e as demandas da situação concreta. Nesse sentido:

"O habitus não é destino, como se interpreta às vezes. Sendo produto da história, é um sistema aberto de disposições que se confronta 
permanentemente com experiências novas e, por isso, é afetado também permanentemente por elas. É duradouro, mas não imutável"

(Bourdieu, 1992: 109).

Os esquemas, modos de fazer, de pensar, compõem o habitus, enquanto as práticas exteriorizam esse sistema de disposições incorporadas. O habitus e as práticas a ele relacionadas são responsáveis pela continuidade ou descontinuidade das estruturas. Para o sociólogo francês:

"é preciso conhecer as leis segundo as quais as estruturas tendem a se reproduzir, produzindo agentes dotados do sistema de disposições capaz de engendrar práticas adaptadas às estruturas, e portanto, condições de reproduzir as estruturas"

(Bourdieu, 2004: 296)

O habitus da prisão afeta diretamente as formas de interação da sociedade civil no cárcere, da mesma forma que presença da sociedade nesse espaço também tem a potência de influenciar as formas de fazer consolidadas na dinâmica prisional, e portanto, reconfigurar esse habitus.

Por isso, a importância do ente da sociedade civil conhecer as práticas da prisão que sustentam a estrutura que se deseja enfrentar, e pensar se suas respectivas ações estão servindo para reproduzir ou combater as mesmas.

\section{- Cartas do jogo e capital}

Bourdieu denomina capital os recursos sociais, culturais, econômicos, simbólicos etc. que o indivíduo possui, que "como una buena carta en un juego, son poderes que definen las probabilidades de obtener un beneficio en un campo determinado" (Bourdieu, 1999: 282).

Nesse sentido a posse dos diversos tipos de capitais, é fundamental para se determinar as possibilidades de jogadas e o alcance delas no campo. As condutas dos agentes são determinadas por sua posição na estrutura de relação de forças e do capital acumulado,

“de modo que su fuerza relativa en el juego, su posición en el espacio de juego y también sus estrategias de juego- (...), las jugadas más o menos arriesgadas, más o menos prudentes, más o menos subversivas o conservadoras - dependen a la vez del volumen global de sus fichas y de la 
estructura de sus pilas de fichas, es decir, del volumen global y de la estructura de su capital..."

(Bourdieu, 1992: 74-75).

O capital é desigualmente distribuído no campo, ou seja, alguns tem mais recursos para atuar no campo do que outros. Essa desigualdade na distribuição contribui à manutenção da estrutura do campo, na medida em que a posse de capital seria uma das condições para o agente promover mudanças, e aqueles que o possuem dificilmente querem modificar a estrutura que consolida sua posição de domínio:

"La visión dominante del mundo social o incluso la producción de taxonomías legisladoras, es el juego de una lucha entre agentes que, según su posición dentro de las distribuciones de diferentes recursos sociales (los espacios de capital, económico, cultural, social) y dentro del espacio de clasificaciones en que se encuentran potencialmente inscritos, están muy desigualmente armados para imponer su visión del mundo y particularmente para actuar al nivel de las denominaciones y de las instituciones..."

(Bourdieu, 2000: 31)

Os agentes são distribuídos no campo de acordo com o volume de capital que detém. No campo prisional, é evidente a desigualdade de distribuição de capital legítimo do campo entre a equipe dirigente e os dirigidos. A fala dos presos e o capital que aportam tem pouco valor na constituição das relações verticalizadas e impostas unilateralmente pelo cárcere.

O voluntário, estranho ao mundo prisional, também carece, aos olhos dos seu gestores, de capital simbólico e social legítimo para interpretar e agir nesse espaço. Por isso, para se manter no espaço prisional, é preciso que o ator social implemente seu capital, e tenha alguns trunfos importantes para jogar com a prisão, tais como apoio pessoal ou institucional, articulação política interna e externa, constituição de rede de relações com presos e funcionários, visibilidade social etc. A posse desses trunfos vai ser determinante à entrada no campo e a permanência na disputa da construção do mundo prisional.

\section{- Voluntários como agentes do mundo da prisão}

Escolhi pensar a ação das pessoas da sociedade civil que ingressam no universo prisional dentro da chave estrutura-construtivismo proposta por Bourdieu: apesar da estrutura 
totalizante da prisão, seus atores disputam o modo de fazer penitenciário no dia-a-dia da instituição.

Mesmo com a rigidez da dinâmica prisional, podem ser abertas possibilidades de novas formas de relação e novos espaços, que resistam ao controle institucional do campo: "os agentes sociais, (...), não são apenas autômatos regulados como relógios segundo leis mecânicas que lhes escapam" (Bourdieu, 2004b: 21). As configurações sociais são produto não só da estrutura, mas da interação entre as pessoas que influem nas formas de comunicação e de regulamentação do espaço.

Cada agente ocupa uma posição no campo, tem incorporado um habitus e possui uma trajetória social. A regularidade das práticas não é fruto de uma submissão cega às regras. As estruturas de Bourdieu não engendram mecanicamente uma conduta no agente, são frutos de uma racionalidade e causalidade não automáticas.

Uma teoria do universo social deve integrar a representação que os agentes fazem do mundo social e a sua contribuição para a construção da visão desse mundo. Dito de outra forma, para a construção mesma desse mundo:

"debe tomar en cuenta el trabajo simbólico de fabricación de grupos, trabajo de representación (en todos los sentidos del término) que los agentes sociales no dejan de realizar para imponer su visión del mundo o la visión de su propia posición en este mundo, de su identidad social"

(Bourdieu, 2000: 30)

Nesse sentido, é interessante interrogar os voluntários e presos sobre suas mútuas representações e percepções acerca da interação sociedade-cárcere, uma vez que o trabalho de produção e imposição de sentido se realiza a partir de lutas no campo de produção cultural, especificamente no interior do subcampo político (Bourdieu, 1999: 291).

A classificação social que se opera na prisão entre presos/funcionários, prisão/sociedade, aproxima-se das oposições dualistas das classificações das sociedade arcaicas mencionadas por Bourdieu: masculino/feminino, alto/ baixo (2004b:165). A entrada da sociedade como mais um ator em interação, pode desacomodar o duplo "dirigentes e dirigidos", e mover as posições no jogo na prisão. Porém, o poder simbólico de constituir, mobilizar, e falar pelo 
grupo "só pode ser obtido ao término de um longo processo de institucionalização" (Bourdieu, 2004b:166).

Conhecer o sentido do jogo da prisão e se manter atuante nesse espaço significa disputar o espaço social e o campo de lutas simbólicas. Nesse sentido, os agentes da sociedade civil, em conjunto com os presos, podem aprimorar e diversificar os instrumentos de produção simbólica para que os presos e a sociedade expressem outros pontos de vista sobre a prisão, possibilitando a "ruptura con las representaciones que se engendran en la complicidad inmediata de las estructuras sociales y mentales y que tienden a asegurar la reproducción continuada del capital simbólico" (Bourdieu, 1999: 300)

$\mathrm{Na}$ disputa pela legitimidade na construção do mundo social, os representantes da burocracia nunca tem monopólio absoluto. No interior da instituição eclodem "conflitos entre poderes simbólicos" na construção daquele mundo social (Bourdieu, 2004b:165).

O poder simbólico, para Bourdieu (2004b:166), consiste em um poder de constituição política e filosófica, que consagra e revela, conserva ou transforma as categorias e estatutos sociais. O exercício do poder simbólico pressupõe a posse de um capital simbólico, ou seja, do "poder de impor às outras mentes uma visão, antiga ou nova, das divisões sociais".

Nesse sentido, ainda que as ações no cárcere se situem em um espaço social determinado, e portanto, tenham um impacto social limitado, elas participam da disputa simbólica de leituras acerca da prisão, dos presos e do papel da sociedade que atravessam o universo em que estão situadas. 


\section{PARTE II}

\section{TRAVESSIA ETNOGRÁFICA: VOLUNTARIADO NAS PRISÕES DA CATALUNHA}

\section{CAPÍTULO 5}

\section{TRAVESSIA ETNOGRÁFICA}

Em uma pesquisa situada em um espaço tão truncado como o prisional, explicitar os caminhos de inserção do campo desvela os mecanismos de poder em funcionamento, e acaba por me levar de volta ao objeto da própria tese. Afinal, muitos dos empecilhos e barreiras criadas para a minha entrada enquanto pesquisadora na prisão são os mesmos com que se deparam as entidades e pessoas da sociedade civil que querem cruzar seus muros.

Neste capítulo, relato minha inserção no campo de pesquisa catalão e alguns resultados da pesquisa de campo realizada durante o segundo semestre de 2010 e o primeiro semestre de 2011.

No início, descrevo o meu processo de inserção no campo penitenciário da Catalunha: estratégias, dificuldades, negociações, etc. Descrevo algumas percepções da configuração do campo (de força e de luta) nesse território, a partir do que denominei travessia etnográfica: o contato com outra cultura para compreender como a ação no cárcere se produz em outros contextos.

A partir de uma curta e localizada incursão (setembro de 2010 a junho de 2011), tentei compreender o fenômeno do voluntariado, forma institucionalizada de entrada da sociedade civil nas prisões catalãs, identificando proximidades e distâncias em relação ao sistema prisional paulista.

Incluo ainda um relato etnográfico da única visita que realizei na Cárcel Modelo, prisão de arquitetura panóptica que surge como modelo de punição no início do século XX, cuja história reflete os eventos políticos e sociais ocorridos na Catalunha. 
Ao final apresento sucintamente as quatro entidades/projetos que compuseram o meu campo: Justícia i Pau; FAS; Teatrodentro; e, Abrir la Cárcel. Realizo apenas uma descrição objetiva das entidades, de forma a contextualizar as falas e as análises do próximo capítulo, cujos temas e categorias surgiram das entrevistas com coordenadores, voluntários, presos, entre outros envolvidos com ações no sistema prisional da Catalunha.

\subsection{Travessia}

"para descobrir é preciso relacionar-se e, no momento mesmo da descoberta, o etnólogo é remetido para o seu mundo, e deste modo isola-se novamente"

(Da Matta, 1978: 32)

De início, é de suma importância marcar os limites da minha inserção e reflexão no campo prisional catalão. Durante o estágio doutoral, não tive a pretensão de realizar uma etnografia, uma descrição densa no sentido referido por Geertz (1978). Vejo minha incursão muito superficial, pontual, limitada, longe de um mergulho no campo, sinto que só pude colocar os pés na orilla ${ }^{113}$ dessas águas.

Além de um transcurso entre culturas, trata-se de uma travessia entre disciplinas, especificamente entre direito e antropologia. Essa tentativa de construção de pontes entre os saberes sociais, por vezes, tira-me o chão. Seja ao me tentar distanciar do modo de fazer e pensar da pesquisa jurídica, seja porque em outros campos das ciências sociais, pareço (e sou) estrangeira, uma vez que me falta uma formação especifica nessas aéreas.

Ainda com os riscos e perigos de estar nesse "não lugar", é essa mesma posição que me permite uma análise multifacetada de um objeto tão complexo como a prisão, a possibilidade de olhá-la a partir de meu próprio caleidoscópio.

Não fechar a pesquisa dentro de um domínio disciplinar é uma resistência contra a “compartimentalização" dos saberes e uma luta contra a disciplina ${ }^{114}$ de um modo geral. Foucault (2006), em La pussage et la nuage, propõe não um encontro interdisciplinar entre historiador e filósofos, mas um trabalho comum de pessoas que buscam desdisciplinar-se.

\footnotetext{
${ }^{113}$ Beira, margem.

${ }^{114}$ Não é por acaso, que as práticas denominadas por Foucault tenham a mesma dominação dos cursos que temos em nossas Universidades.
} 
Por isso, nomeio essa experiência "travessia". Ao fazê-lo, percebo como essa imagem (quase poética ${ }^{15}$ ) se aplica não só a este período de minha pesquisa, mas faz referência ao meu próprio objeto. A sociedade civil (e o pesquisador) atuam na liminaridade (Turner, 1974), no intermédio de dois universos, comunicando a prisão com o mundo externo a ela.

\subsection{A necessidade etnográfica}

Desde o início do desenho desta pesquisa, tive claro que a aproximação com o fazer etnográfico poderia trazer uma abertura importante para a minha análise geral. A certeza disso veio pelo conhecimento teórico (e afetivo) do campo, somado à percepção de que uma contribuição original à discussão criminológica passaria pela compreensão específica de uma realidade, principalmente por meio de pesquisas qualitativas e etnografias- com as quais já vinha dialogando desde o Brasil.

Olhares circunscritos podem nos dizer muito mais sobre as práticas na prisão do que uma tentativa de elaboração de una grande teoria, por ao menos dois motivos. Primeiro, porque muito já foi escrito acerca da prisão, da ressocialização e de seu fracasso. Uma forma de suporte para a construção de um novo saber criminológico, que rompesse com as evidências, seria a produção de um saber não universal, situado em um espaço e tempo presente, no sentido do événementialiser ${ }^{116}$ proposto por Foucault (1980).

Além disso, a etnografia leva à percepção de minúcias e sutilezas da realidade observada. A prisão é por excelência o espaço do não-dizível, o que acontece e o que se sente na vida no cárcere não são temas facilmente verbalizáveis ${ }^{117}$. Nesse espaço onde o uso da palavra é regulamentado e os discursos (des)legitimados a todo momento, o uso de ferramentas rígidas, como o questionário ou a entrevista, nos dá acesso apenas a uma parte da história.

As coisas mais interessantes que se depreendem na prisão são as que se falam ao pé do ouvido, pelas grades, pelos olhos, pelas mãos. O tom da voz; o cheiro característico do

\footnotetext{
${ }^{115} 1$ Ato ou efeito de atravessar uma região, um continente, um mar. 2 Distância entre dois pontos marítimos ou terrestres. 3. Longo trecho de caminho desabitado. (http://michaelis.uol.com.br)

${ }^{116}$ Foucault atribuirá a "acontecimentalização" duas importantes funções teórico políticas: a observação de uma ruptura da qual pode surgir uma singularidade (por exemplo não era tão necessário que a loucura fosse transformada em doença mental); e, ainda, reencontrar conexões, apoios, bloqueios, jogos de força e estratégias que em dado momento formaram o que mais tarde seria considerado uma evidência, uma universalidade.

${ }^{117}$ E no Brasil, para além da censura da administração prisional, existe a presença das facções criminosas exercendo um controle sobre o que é dito entre os muros.
} 
ambiente (pelo cheiro, pode-se distinguir as diferenças entre as condições materiais de uma prisão para outra, de um setor para outro); o "clima"; a forma de se vestir que denuncia a diferença social e institucional de seus personagens; as pequenas regulamentações e suas sutis transgressões.

\subsection{Reconhecendo o terreno}

A expectativa de encontrar interlocutores afinados com minhas ideias funcionou como um poderoso filtro dos projetos que selecionei. Julguei-os mais interessantes à medida que neles identificava as minhas próprias concepções acerca de intervenção no espaço prisional.

Logo, meu olhar sobre o campo foi construído a partir desse recorte, que incidiu desde a pesquisa exploratória, mas principalmente na seleção dos projetos a serem analisados em profundidade. A decisão de não incluir no campo entidades que tivessem por objetivo imediato a educação formal, a realização de oficinas de trabalho ou assistência religiosa, foi uma maneira que encontrei de me aproximar de entidades que não ocupavam os campos tradicionais da reabilitação (escola e trabalho), e cujas práticas fossem além da tarefa da salvação do preso, da busca de sua renovação ética por meio do trabalho, estudos, arrependimentos, e privações.

Porém, ao começar a circunscrever quais seriam essas práticas, deparei-me com a "perspectiva da reabilitação-redenção" enraizada nos discursos, modos de fazer, e formas de sentir daqueles que se propõem ir ao cárcere, e inclusive em mim.

Mais tarde percebi que o incômodo que senti no início da minha pesquisa em território catalão, era devido ao fato de não conseguir situar o que acreditava ser meu trabalho no Brasil (frente ao GDUCC) na realidade catalã. Meus interlocutores, de forma geral, ou eram críticos, mas não tinham atuação no cárcere ${ }^{118}$ (e, muitas vezes, nem fora dele), ou atuavam no cárcere acreditando na sua melhora e sempre futura eficácia.

Eu, que até então me acreditava crítica e atuante no cárcere, ao tomar contato com essa configuração, e depois de escutar a mesmice dos discursos acerca da ressocialização dos

\footnotetext{
${ }^{118}$ Destaco aqui a Oficina Social Antropología y Prisión e Observatório del Sistema Penal y Derechos Humanos (OPDH- Universitat de Barcelona).
} 
voluntários da Catalunha, não sabia aonde me situar. Por vezes, identificava-me com os discursos desses voluntários, e questionava a solidez política da ação na prisão que eu mesma propunha. Esse questionamento abalou todas as minhas certezas, ocasionando um enorme incômodo, e dúvidas sobre o que saber e como fazer.

Essa inquietude não foi fruto de um mero percalço na pesquisa, por isso persiste. Ela advém de um questionamento central a esta pesquisa, e que há alguns anos acompanha minhas práticas no cárcere: é possível atuar na prisão e contra ela ${ }^{119}$ ?

\subsection{Reconhecida pelo terreno}

A minha condição de pesquisadora na Catalunha guardava duas particularidades: era estrangeira e estava de passagem. Essa condição produziu efeitos opostos: dificultou a consolidação de uma relação de empatia e confiança com meus informantes e autoridades penitenciárias, ao mesmo tempo em que contribuiu para minha entrada nas prisões.

Permitir a abertura ao olhar estrangeiro era uma decisão que ia ao encontro da imagem que a Generalitat de Catalunya queria transmitir acerca de seu próprio sistema prisional: democrático e aberto; ao mesmo tempo, o fato de que eu estava de passagem, garantiria que "não traria problemas" a longo prazo.

Meus informantes faziam uma leitura própria da minha condição na Catalunha. Por mais que tenha insistido no fato de que eu estava realizando uma pesquisa acadêmica, e que não se tratava de uma pesquisa aplicada ${ }^{120}$ (ao menos, não imediatamente), frequentemente era vista pelas pessoas das entidades que acompanhava, e pela burocracia, como uma enviada pelo governo brasileiro para planejar um modelo/projeto de voluntário. Como nas palavras do responsável do Departament de Justícia:

"autorizem a entrar ao centro a Sra. Ana Gabriela Braga, que, há um ano, deu início na Catalunha a um estudo sobre os voluntários nas prisões catalãs

\footnotetext{
${ }^{119}$ Esses questionamentos passaram a ocupar um papel central em minhas reflexões. Eles tiveram seu estopim em Barcelona, quando estava realizando trabalho de campo e revisitando a obra de Mathiesen "The Politics of Abolition", no qual ele aponta um dilema (irresolúvel) reforma versus revolução, objetivos a curto prazo versus objetivos a longo prazo.

${ }^{120}$ Acerca da pesquisa aplicada fundamental a discussão proposta por Cunha (1991).
} 
sob o encargo da Universidade de São Paulo para a implementação de um programa de Voluntariado no Brasil" 121

Um dos meus principais informantes, que denomino "voluntário-modelo", atuante na prisão há mais de 17 anos e com o qual tive inúmeras conversas, me apresentou (com muito orgulho) aos presos como a "responsável de levar aquela experiência ao outro lado do Atlântico".

Já os presos costumavam me identificar com a figura dos voluntários. Na maioria das $\operatorname{visitas}^{122}$, só me foi possível estabelecer um contato rápido com os presos, um espaço de interação curto, no qual era difícil de me diferenciar daqueles com os quais eu chegava no cárcere, e cuja origem social era muito próxima à minha.

A representação de diversos papéis me colocava como "agente dupla" nessas dinâmicas. Para caminhar nessa rede, eu manipulava minha identidade, ora me colocando do lado dos voluntários, ora dos presos, ora me colocando como uma "realizadora de projetos". A cada interlocutor revelava uma faceta, e a muitos deles silenciei minha crítica.

\subsection{Negociação com o campo}

Se a negociação com o campo é uma questão chave para qualquer etnografia, ela adquire uma especial dimensão no espaço carcerário. Primeiro, porque nas prisões existem muitos segredos, que, para Foucault, são algumas das formas de poder político; por isso, evita-se a todo custo que eles sejam revelados a alguém estranho a esse espaço.

Além disso, o processo para se conseguir autorização de entrada nas penitenciárias não obedece a uma lógica linear, e suas decisões não tem força definitiva, estão sempre sujeitas as intempéries sociais e conjuntura políticas. Logo, a condição de permanência do pesquisador no cárcere é sempre precária e provisória.

Uma das preocupações centrais da minha pesquisa era se (e como) eu conseguiria a permissão para entrar nas prisões e acompanhar a ação das pessoas das entidades da

\footnotetext{
${ }^{121}$ Tradução da autora. No original em catalão: “autoritzem a entrar al centre a la Sra. Ana Gabriela Braga que, des de fa un any, duu a terme a Catalunya un estudi sobre el voluntariat a les presons catalanes per encàrrec de la Universitat de Sao Paolo per a la implantació d'un programa de Voluntariat al Brasil.."

${ }^{122}$ Pela "via formal" não consegui autorização para entrevistar ou conversar com os presos reservadamente. Retomarei este tema mais adiante.
} 
sociedade civil. Para tanto, foi necessária uma negociação constante e uma articulação em diversos níveis: Departamento de Justiça, direção do estabelecimento prisional, presos, entidades da sociedade civil e voluntários.

Ademais, meu campo não estava circunscrito a um espaço prisional determinado, uma vez que era o trabalho do voluntário que pautava o Centro Penitenciário que eu visitaria, e não ao contrário. Esse constante deslocamento não permitia ganhar a empatia e confiança dos informantes, tampouco das autoridades responsáveis pelo estabelecimento prisional. E fez com que, em cada entrada, eu tivesse que seguir todo o protocolo da burocracia prisional: espera, apresentação, negociação, reconhecimento.

\subsection{Eleição de um tema "vendável"}

O desenho estratégico dessa pesquisa, com fins de superar os previsíveis obstáculos para entrada no campo prisional, começou com a eleição do tema. Meu olhar recaia sobre as pessoas da sociedade civil que entram no cárcere, e portanto, meu foco estava em um lado "iluminado" da prisão. Essa escolha certamente facilitou o meu acesso ao campo prisional, ao mesmo tempo em que me manteve alijada dos seus espaços mais sombrios. Segundo Barbero (2009:119):

"Aun con estas dificultades iniciales, el permiso puede obtenerse, pero por
si mismo no proporciona una libertad plena al investigador. Éste puede
tropezar con no pocos obstáculos si se adentra por vericuetos no deseados
por la institución"

Enfocar um lado aparentemente positivo da realidade penitenciária, tal como o voluntariado, iria de encontro a um tipo de saber que a Secretaria de Serveis Penitenciaris, Rehabilitació i Justícia Juvenil Generalitat de Catalunya (SSPRJJ) ${ }^{123}$ tinha interesse em produzir e reproduzir. $\mathrm{O}$ fato de minha pesquisa não ter como objeto o estudo da prisão, ou dos presos, foi fator determinante para a boa recepção do projeto pela SSPRJJ. Com o discurso de que queria conhecer as "boas práticas" realizadas na prisão da Catalunha, pude ocultar mais facilmente a minha postura critica em relação à instituição penitenciária. Dessa forma, afastava-se o risco para a Administração Penitenciária de apoiar uma pesquisa-denúncia da situação carcerária na região.

${ }^{123}$ De aqui por diante SSPRJJ. 
Uma característica intrínseca à instituição prisional é seu hermetismo. O fechamento em relação ao entorno social subsiste em todas as prisões, e se manifesta como um mecanismo de defesa contra a incursão de práticas e pessoas que tencionem a instituição.

A entrada no cárcere de pessoas estranhas à sua dinâmica é vista como uma ameaça ao controle e à segurança. $\mathrm{O}$ discurso institucional se vale desse argumento para restringir o acesso dessas pessoas. Porém, a instituição, com seu hermetismo, tenta preservar algo além da ordem: o monopólio sobre os "modos de saber-fazer" na prisão.

De acordo com Goffman (2005), uma instituição total é composta basicamente por dois grupos de atores: os dirigidos e os dirigentes. O primeiro é mais numeroso, formado pelos internos, e o segundo, menor, formado pelos dirigentes e demais funcionários. Ainda que se possa questionar o caráter total da prisão (ainda mais no Brasil), a dinâmica prisional se compõe de atores com papéis definidos; e o pesquisador, ou o voluntário, não encontram seu correspondente nesta classificação. O fato de ocupar um "lugar institucional indefinido" já é suficiente para que sua presença seja elemento perturbador da dinâmica prisional.

Logo, quanto menos o "estranho" tencione essa lógica binária melhor para a administração prisional. A aceitação no meio institucional está vinculada diretamente ao posicionamento nessa dinâmica: quanto mais identificado com a equipe dirigente e afinado com os propósitos institucionais, mais fácil será a negociação de entrada e a permanência nesse campo.

A escolha de entrar na prisão acompanhando o trabalho das entidades da sociedade civil mostrou-se importante como estratégia não só para legitimar meu trabalho perante a administração prisional, mas também porque essas entidades foram mediadoras da minha entrada nos estabelecimentos prisionais. De novo Barbero (2009, p. 119):

"El problema de estas investigaciones (en espacios cerrados) es el de la excesiva dependencia del observador a la institución. La administración habrá de conceder previamente un permiso y, normalmente, lo condicionará a la realización de una actividad que no complique los intereses institucionales. En el caso de la prisión, el permiso lo supeditará a la participación del estudioso en tareas de reeducación y reinserción social, tal como estas actividades son entendidas por el sistema 
penitenciario. Por eso, son grupos, religiosos o civiles, previamente organizado en asociaciones, los más aptos para conocer de cerca la vida penitenciaria. Un investigador independiente, no perteneciente a estas asociaciones, es un personaje en principio extraño al mundo de la prisión".

\subsection{Estratégias de entrada}

Desde o principio, acreditei na importância de entrevistar os voluntários, e escutar seus discursos. Era imprescindível acompanhar suas ações no espaço prisional, contextualizar as falas, ver a dinâmica que se cria nessa interação.

Era também quase um imperativo ético escutar aos presos, dando-lhes a oportunidade de falar da atividade da qual participavam, e submeter o outro à avaliação, nesse caso, o voluntário. Ainda que essa estratégia buscasse, de alguma forma, mexer com a posição que os presos ocupam como objetos preferenciais e permanentes de investigações e exames; eu estava atuando ali com uma vontade de saber, com consciência da impossibilidade de me despir do papel de investigadora, e mesmo, de um modo de fazer inquisitorial (Ginzburg: 1991).

Com o objetivo de possibilitar a entrada no campo prisional, e assim, acompanhar a dinâmica criada pelos voluntários e falar com os presos, elaboramos ${ }^{124}$ duas estratégias para a minha entrada nas prisões:

> "VIA FORMAL": entrada na prisão pela via burocrática, o que significava enviar meu projeto para apreciação da Comissió de control $i$ seguiment dels estudis $i$ investigacions en l'àmbit de l'execució penal (Departament de Justicia, SSPRJJ)

- Risco: que os tramites burocráticos demorassem mais que minha própria permanência na Catalunha.

$>$ "VIA INFORMAL" / "comer pelas bordas": começar o contato com as entidades e a partir delas me aproximar dos Centros Penitenciários, o que parecia interessante já que de qualquer forma eram os atores dessas entidades os personagens centrais de minha pesquisa.

- Risco: "ficar nas bordas" e não adentrar o espaço prisional.

\footnotetext{
${ }^{124}$ Agradeço o apoio do professor da Faculdade de Antropologia de Universitat de Barcelona, Julio Zino Torraza, nesse planejamento e durante todo o período de minha investigação.
} 
Resolvemos então, que atacaria simultaneamente nas duas frentes: enquanto aguardava o parecer da comissão começaria o contato com as entidades de voluntariado, a princípio com seus diretores, e em seguida, com os próprios voluntários.

No começo de outubro entreguei pessoalmente meu pedido ao responsável pela Comissió, em uma rápida reunião agendada na própria SSPRJJ. Expliquei o objetivo geral de minha pesquisa "entender como e porque a sociedade civil entra no cárcere", explicando que teria interesse de entrar nas unidades prisionais nas quais meus informantes realizavam o voluntariado.

O representante da Secretaria na época disse-me de antemão que seria de interesse para a SSPRJJ um estudo desse tipo, e indiretamente, que esse era um critério para a concessão das autorizações a pesquisadores.

Saí da reunião com um bom pressentimento. A resposta veio somente em fins de dezembro nos seguintes termos: "La Comisión autoriza el estudio y la entrada en los centros siempre que vaya acompañada de una institución" (grifo meu).

Porém, em final novembro de 2010, as eleições para presidente e parlamento da Generalitat, com a vitória da direita liberal nacionalista $\mathrm{CiU}^{125}$, ocasionaram diversas mudanças nos quadros e nas políticas do Departament de Justícia. A pessoa que estava acompanhando meu processo informou-me que mudaria de função, indicando outra que estaria responsável a partir de então. Como previ à época, tal mudança prejudicou-me duplamente: primeiro, porque teria que refazer a aproximação com a SSPRJJ; e, depois, porque a abertura que havia encontrado em um primeiro momento não se repetiria nessa nova conjuntura política.

A minha inserção no campo prisional catalão não seria fácil. Inocentemente, havia acreditado que, tendo sido minha entrada consentida pela Comissió, órgão máximo de deliberações desse tipo na Catalunha, as portas se abririam para mim. Mas percebi que seguia no labirinto, e que ali permaneceria durante toda a pesquisa. Teria a todo tempo que me articular politicamente com os voluntários, diretores das entidades, funcionários do

\footnotetext{
${ }^{125}$ Coalición Convergència i Unió.
} 
sistema penitenciário e a SSPRJJ, convencendo-os a colaborar com os meus propósitos, e apoiando-me ora em um ora em outro para legitimar minha pesquisa perante os demais.

A negociação com meus informantes e o delineamento de estratégias levou-me a uma série de questionamentos éticos acerca da minha verdade nesse emaranhado de inter-relações e interesses. As autorizações, entrevistas e amabilidades foram negociadas a partir de uma expectativa de retorno da minha parte. A SSPRJJ e os responsáveis por algumas entidades condicionaram a sua participação a um futuro feedback das minhas observações. Eu consenti, afinal essas cláusulas não estavam em negociação. O que estava em jogo era a possibilidade de eu realizar o campo, mas tinha muitas dúvidas em que tipo de retorno poderia lhes dar.

\subsection{Alcance das estratégias}

\subsubsection{Estratégia 1: "VIA FORMAL"}

Por esta via, o processo de autorização a um Centro Penitenciário resultou custoso e cansativo- como há de ser a burocracia. O trâmite passava por uma série de e-mails, telefonemas e acertos. Eu precisei tecer uma rede de comunicações que envolvia o responsável pela entidade do voluntário, o voluntário, o responsável da SSPRJJ e o diretor (ou coordenador de área) do Centro Penitenciário.

Minhas visitas daí resultantes foram pontuais. Acompanhava o voluntário em um dia de atividade no Centro Penitenciário. Tampouco foi me permitido acesso a outros espaços da prisão, senão àqueles onde o voluntario realizava seu trabalho. No caminho que levava ao “espaço permitido", fazia perguntas àquele que me guiava, olhava e escutava curiosa o movimento dos presos nos raios e outros espaços menos visíveis.

Não tive autorização formal para entrevistar aos presos e presas. As exigências e limites impostos pela SSPRJJ para regular o tempo, espaço e temática da minha visita, impossibilitavam (ainda que não declaradamente) meu diálogo com os internos e internas. Meus limites no espaço prisional foram circunscritos pelo medo, por parte dos detentores do saber oficial, da liberação da fala dos presos e do saber produzido desde aí.

Já sabendo dessa limitação, aproveitava os momentos informais, e a ausência de funcionários do cárcere, para puxar conversações sobre o que me interessava, em grupo ou 
individualmente. Pelas condições desses diálogos, não pude aprofundar uma conversa com nenhum interno ou interna nessas visitas.

Por essa via entrei em três Centros Penitenciários: d'Homes de Barcelona (a famosa Presó Model), o Módulo semiaberto de Brians 1, e de Dones de Barcelona (Wad Ras).

\subsubsection{Estratégia 2: "VIA INFORMAL"}

A segunda estratégia se mostrou muito potente em relação a um dos grupos que acompanhava, e me permitiu um acesso contínuo a um Centro Penitenciário específico. Nesse caso, entrei "pelas mãos" dos coordenadores do projetos Teatrodentro, que após seis anos de trabalho, tinha conquistado reconhecimento, relativa autonomia, e possibilidade de movimento naquele espaço prisional.

Por esse meio, tive possibilidade de acompanhar o grupo em vários momentos e ter conversas reservadas com os presos. Devido ao contato contínuo e a abertura do grupo ao meu olhar, tive espaço para conhecer e ser conhecida, criar certa familiaridade, intimidade, confiança.

Por essa via fui diversas vezes a prisão de Quatre Camins. Ademais fui a Lledoners (Manresa) e Brians 1, para acompanhar a apresentação de teatro do grupo no Festival InOut, realizado fora e dentro de diversos estabelecimentos prisionais da Catalunha.

\subsection{Um relato etnográfico: Visita a La Modelo}

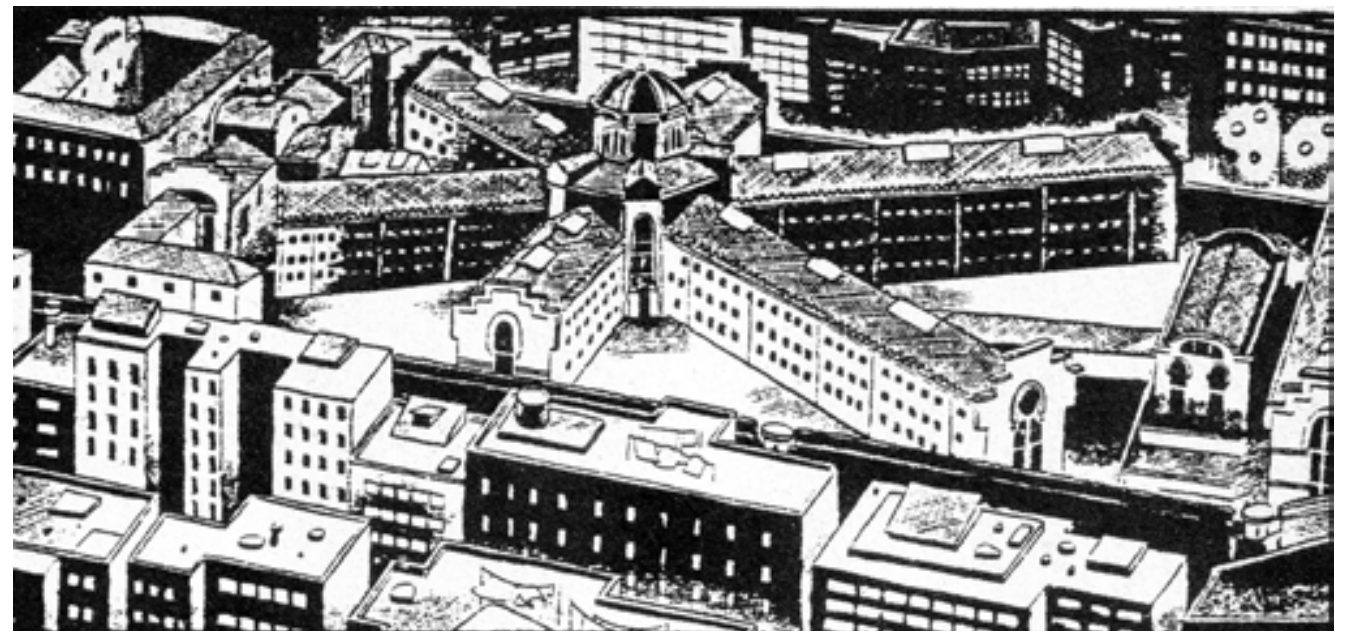

Ilustração: Miguel Gallardo 
Em fevereiro de 2011, depois de quatro meses de negociação com as autoridades prisionais, consegui autorização para visitar Centre Penitenciari d'Homes de Barcelona, conhecida por Presó Model ou mesmo La Modelo. Iria acompanhar Angel, que há dezessete anos, ministra aulas de reforço de catalão, castelhano e matemáticas para o exame de acesso à Universidade à distância.

Antes mesmo de pisar em solo catalão já desejava conhecer La Modelo, a materialização do sonho panóptico que sobrevivia há mais de cem anos no coração de Barcelona. Esse desejo se acentuou na medida em que me aprofundava na história e nas questões penitenciárias da Catalunha.

La Modelo é um ícone do sistema penitenciário catalão. Construída em 1904, seu apelido vem da sua arquitetura exemplar que no início do século servira de modelo de racionalidade e utilidade no exercício do poder. Nos mais de cem anos de existência, a prisão foi um aparato utilizado na Guerra Civil Espanhola, na ditadura de Franco, viveu a epidemia da heroína nos anos 80 , e hoje é uma peça importante na maquinaria do controle do tráfico e da imigração. Um lugar de opressão por excelência, que também foi palco de inúmeras revoltas, greves e atos de resistência.

Um Centro Penitenciário singular no sistema prisional catalão. É um centro para abrigar somente presos provisórios, que conta com aproximadamente dois mil presos, entre condenados e preventivos. Um relatório de 1990 publicado pelo Defensor del pueblo sobre a situação penitenciária da Catalunha, aponta para as especificidades de La Modelo, que dificultariam, ainda mais, a possibilidade de reabilitação:

"La masificación en el centro, así como su estructura y condiciones de habitabilidad repercuten directamente no sólo en la imposibilidad práctica de llevar a cabo las actividades rehabilitadoras del tratamiento previstas en la Ley Orgánica General Penitenciaria en desarrollo del artículo 25 de la Constitución española, sino que incluso puede generar, en algunas ocasiones un mayor deterioro del interno del que presenta a su ingreso"

(Defensor del pueblo, 1990: 37)

A tendência da política penitenciária catalã é substituir esse "modelo" por centros penitenciários novos, menores, afastados dos grandes centros. Apesar do investimento no setor, e da construção de diversos centros penitenciários, as vagas nunca são o suficiente. 
A taxa de emprisionamento só faz crescer, e a Modelo segue sendo necessária. Dessa forma, a desativação da Modelo aparece como um mito para os catalães, assim como as histórias que ela abriga. No momento da minha visita, fui informada que ela está em processo de esvaziamento. O governo promete sua a desativação para 2014.

Fazendo uma pesquisa situada em São Paulo e na Catalunha, não há como não associar a Cárcel Modelo ao nosso Carandiru, por muitos anos um símbolo do sistema prisional paulista, que chegou a abrigar sete mil presos, desativado no ano de 2002.

Fui da minha casa até a penitenciária de bicicleta. Andar de bicicleta foi desde a minha chegada meu meio de transporte em Barcelona, além de meu hobby favorito: para mim, sentir o vento na cara era uma vivência forte de liberdade. No caminho, ao me lembrar que estava indo em direção a uma prisão, essa vivência foi contrastada com a realidade asfixiante daquele espaço; esse contraste me gerou uma angústia imensa, e até um estranho sentimento de culpa por me sentir tão livre. A resposta de um dos presos a uma pesquisa na Espanha $^{126}$ resume um pouco o paradoxo em que me vi. Ao ser perguntado o que faria se estivesse em liberdade, respondeu que gostaria de "andar um quilometro em linha reta".

Já conhecia a Modelo por fora. Um dia, voltando pra casa, vi um cartaz que divulgava a $14^{a}$ Marxa Contra les Presons, a ser realizada no dia 31/12/2010. A marcha começaria na Presó de Dones (Wad-Ras), seguiria para o CIES (Centre d'Internament per a persones estrangeres) e finalizaria na Presó Model.

Era início da última noite do ano, fazia frio em Barcelona, quando eu, meu marido e um casal de amigos fomos para o final da manifestação que ocorria nos arredores da Presó Model. Havia cerca de 200 pessoas com tochas, fogos de artifícios e dois gritos de guerra: "los ricos nunca entran, los pobres nunca salen" e "Abajo los muros de las prisiones". Entre nós e a prisão havia um grande cerco policial, de farda e capacetes pretos, e cassetete em punho. Não presenciei nenhuma confusão.

126 “Andar $1 \mathrm{~km}$. en línea recta: la cárcel del siglo XXI que vive el preso". Produzido a partir da análise de 1.7000 questionários, enviado por correio às pessoas presas na Espanha, realizada por Manuel Gallego, Pedro Cabrero, Julián C. Rios e José Luís Segóvia. 
Talvez tenha sido a primeira vez que tentei imaginar como seria a última noite do ano na prisão: como celebrariam os presos? Estariam sonhando com o próximo ano? De fora, só ouvia gritos incompreensíveis dos presos, que mostravam que tinha vida e voz atrás do muro. Essa experiência me impactou, e chorei uma esperança triste. Para mim, a força da marcha não estava na eficácia quanto ao impacto na sociedade, mas no símbolo que ela carregava: em meio às comemorações nas ruas e casas da cidade, alguém lá fora soltava fogos e gritava a existência das pessoas presas. Na noite que antecede o ano novo, que carrega suas eternas promessas de mudança.

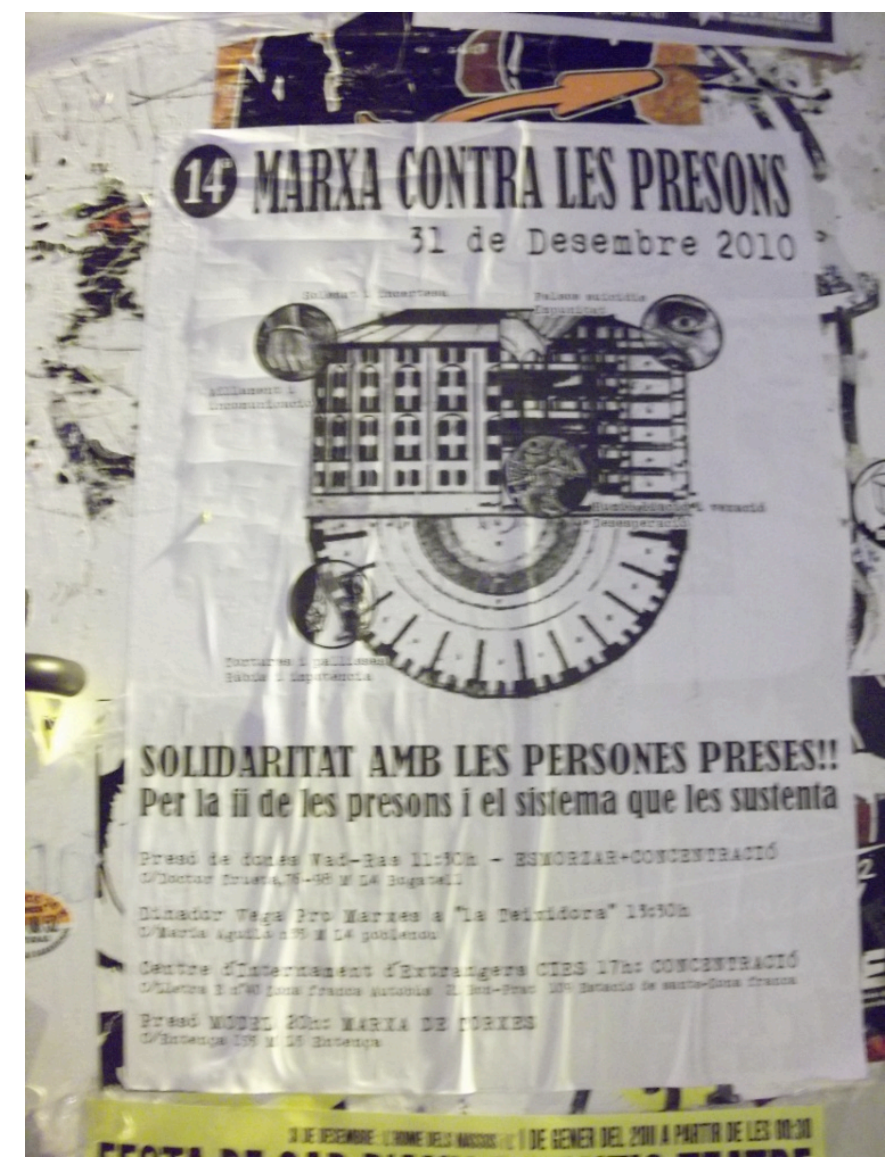

Como mostra a representação gráfica do cartaz que convocava para a Marxa Contra les Presons, a Modelo é reconhecida por sua famosa arquitetura panóptica. A prisão ocupa um quarteirão no bairro de Eixample, vizinha ao Hospital Clinic. O bairro e suas construções modernas do início do século XX foram frutos de um planejamento exemplar, com vistas a criar espaços utilitários ao exercício do poder disciplinar. Não por acaso, o bairro de Eixample concentra três importantes instituições de sequestro: a prisão, o hospital e a escola; e suas ruas são retas e paralelas, compondo formas quadradas, muito diversas das 
que se encontra em outros bairros de Barcelona, tal como o bairro Gótico, formado a partir de um labirinto caótico das ruas.

O único acesso a La Modelo se dá por uma porta pesada de madeira que abre-se desde a rua, sem maçaneta, bastando que a empurre para dentro. Esperei um pouco na porta, para entender o seu mecanismo e quando vi alguém sair aproveitei para entrar. Do lado de dentro, havia um pátio que parecia um pátio escolar, com bancos, máquina antiga de café, refrigerante e sorvete ao lado do que parecia ser um ambulatório, no qual pessoas da rua entravam e saiam. No canto esquerdo havia uma fila de pessoas, marcando hora de visita ou entrega de paquetes aos presos. De um arco que se abria no canto esquerdo da entrada, dava para ver a rua e algumas varandas de apartamentos ${ }^{127}$. Havia uma única porta em um estreito corredor que dava acesso ao interior da Penitenciária. Por lá entravam e saiam funcionários, voluntários, visitas.

Eu estava sentada no banco observando o movimento, quando notei que um agente de segurança me olhava desconfiado, mas não me apresentei. Tinha de esperar Jordi, do Departament de Justícia, o responsável por conceder-me autorizações de entrada nos centros penitenciários. Para minha surpresa, e orgulho do voluntário que eu iria acompanhar, Jordi havia falado que estaria presente na minha visita. Para mim, esse "tratamento especial" por parte da SSPRJJ, representava a preocupação do governo com a entrada de pesquisadores e pessoas da sociedade civil na Modelo.

Vi então um senhor de crachá passar pelo pátio e dirigir-se ao controle de autorizações de visita. Ouvi-o desde dentro falar alguma coisa sobre voluntário. Percebi que era comigo e me apresentei.

Era Quin, o subdiretor da prisão, que me informou, com certo fastígio, que Jordi não viria. Como o diretor também teve que se ausentar, seria ele o encarregado por me acompanhar pelas dependências da prisão. Antes de entrarmos, Quin, em tom de brincadeira, advertiume para que deixasse celulares, drogas e a armas junto à minha bolsa guardada em um setor burocrático da Modelo.

\footnotetext{
${ }^{127}$ Os apartamentos vizinhos ficavam realmente perto da Modelo, há uma história conhecida de um preso que dentro da prisão, foi alvo de tiros disparados de uma janela da vizinhança.
} 
Recebi um "permiso amarillo", o qual tive que apresentar junto ao meu passaporte em todas as "jaulas", assinando a hora de entrada e a saída. Durante o caminho, ele me pareceu entediado, como se não tivesse interesse nas coisas que eu lhe falava. E logo nos primeiros passos já senti o cheiro que não pode ser descrito de outra forma menos tautológica do que "cheiro de prisão", o qual pode ser reconhecido também nos centros de menores, manicômios, e outros lugares com muita gente e pouca higiene.

$\mathrm{Na}$ minha trajetória profissional, tive a oportunidade de visitar pessoalmente diversos tipos de instituições de confinamento. E quanto mais as conheço, mais se fortalece minha percepção que tem algo nessas instituições que se repete sob diferentes formatos e apesar das diferenças socioculturais.

Ainda que minha bagagem nesse campo venha a partir da minha interação em instituições brasileiras, ao entrar nas prisões na Catalunha, senti-me de certa forma familiarizada com os códigos prisionais de lá, com capacidade de situar meu lugar, e dos meus interlocutores nessa trama. Reconheço o papel incômodo que cumpro como pesquisadora, os lugares que posso entrar, o que me é permitido perguntar, as hierarquias, os seus modos de fazer, de controlar, seus cheiros, o discurso institucional, a dificuldade de acesso.

Atravessamos quatro jaulas em linha reta até aceder ao circulo central da prisão. A imagem desde ali é forte: um centro com pé direito altíssimo, com uma cúpula em cima e no meio uma pequena cabine redonda de controle. Do centro irradiavam seis raios, chamados galerias (com seus respectivos números em cima da porta de acesso). Tentei dar uma espiada para ver como era dentro, as celas, mas não consegui.

Recorro à obra de autoria coletiva "Cárcel Modelo 1904-2004" para compreender um pouco da historia centenária dessa instituição e conhecer lugares que não me foram revelados.

"seis galerías de esta cárcel que parten radialmente del Centro de Vigilancia hay un total de 608 celdas útiles para encerrar presos, cada una de ellas de unos 9 metros cuadrados son unos cubiculos sucios, húmedos, donde se colocan las roñosas literas, con un lavamanos y un wáter separado por una endeble estructura de hierro y unas mamparas de metacrilato transparente; las plagas de parásitos: pulgas, piojos y sobre todo chinches hacen la supervivencia más difícil y tensa. En cada celda, se 
hacinan 3 o 4 presos, pero fácilmente en verano, en que cada año aumenta sistemáticamente"

(Producción colectiva, 2004: 57)

A capela foi o primeiro lugar que entramos, era uma sala pequena com um altar à frente, alguns instrumentos musicais e algumas cadeiras. Quin me explicou que ali se realizavam trabalhos voluntários ligados à assistência religiosa. Fui apresentada a duas voluntárias da Justícia i Pau., que conversavam com alguns presos. Estavam acompanhadas por uma outra voluntária da SEPAP (Pastoral Penitenciaria de Barcelona), que era jornalista e monja, e que estava ali ensinando violão, e ensaiando com os presos os cantos para missa de domingo. Ali havia também um voluntário das Testemunhas de Jeová falando com dois presos.

Em um momento da conversa, Quin pediu licença e me deixou nas mãos de um educador. Passados alguns minutos esse me apresentou a Rosa, chefe de setor, que me acompanharia dali pra frente. Senti que a responsabilidade por me acompanhar estava sendo passada de mão em mão, e que nenhum dos meus cicerones entendiam muito meu papel ali. Para minha sorte, Rosa era uma figura interessante. Dela ouvi pela primeira vez alguém dizer que seu sonho de criança era trabalhar na penitenciária. Ela já havia sido voluntária, enquanto trabalhava na maior loja de departamentos da Espanha para pagar a faculdade e estar aonde está hoje.

Saindo do centro de controle, fomos ao pateo general, a parte "mais aberta" da Modelo. O clima da prisão não era dos melhores. Os funcionários pareciam estar alertas e ouvia-se os gritos dos presos trancados. Seus corredores cheiravam a produto de limpeza, e o cheiro piorava à medida que eu passava pelas galerias, onde ficavam a maioria dos presos, ociosos. Os poucos que saiam das galerias se distribuíam entre: oficinas de trabalho (um galpão ao fundo com algumas atividades), escola (5 salas precárias e pequenas, que lembravam um jardim da infância), quadra poliesportiva (aonde alguns presos jogavam bola e mantiveram-se indiferentes à nossa presença) e academia (cheia e cujas vagas eram muito disputadas entre os presos).

No fundo da Modelo havia uma salinha de teto muito baixo, ao lado de um jardim, aonde estava Angel e doze alunos. O voluntário-professor nos recebeu com festa, e talvez um pouco decepcionado porque não estavam todos os convidados. A possível presença de 
Jordi (representante da SSPRJJ) e do diretor da prisão significavam muito para Angel ${ }^{128}$. Ele, que já fora condecorado pelo Departament de Justícia por seu trabalho de voluntariado, via no interesse do Departament mais um reconhecimento do seu trabalho. Lembro-me que Angel ligou na minha casa só para contar, com certa excitação, que havia falado ao telefone com Jordi a respeito da minha pesquisa.

Eu e Rosa entramos na sala de aula, fui apresentada por Angel aos alunos "como aquela que iria levar a experiência deles para outro continente”. Os presos aparentavam estar animados na minha presença, mas agiam disciplinadamente com seus cadernos e lápis, enquanto Angel explicava fórmulas matemáticas no quadro negro.

Sentei em uma carteira ao fundo. O pé direito baixo e as cadeiras pequenas da sala improvisada depois de um jardim, faziam com que me sentisse pequena, em tempos de pré-escola; mas quando de pé, o teto parecia encostar na minha cabeça, e meu corpo adulto sentia-se oprimido pelo espaço. A arquitetura da sala era funcional para a infantilização e contenção do indivíduo, e, portanto, para a disciplina que se exige nas escolas e prisões.

Comecei a acompanhar a aula de matemática, com fórmulas que pareceram muito difíceis para alguém como eu, há tantos anos afastada dos saberes exatos. Fiz alguma brincadeira com isso, e estrategicamente, como uma forma de explicar algo que estava mais ao meu alcance, Angel decidiu mudar a aula de matemática para de catalão. Um dos presos que estava sentado perto de mim reclamou timidamente, mas a ponto de eu ouvir sua insatisfação em relação à mudança. Minha presença fez com que o professor mudasse o curso das aulas sem ao menos consultar os alunos.

Nesse momento percebi que aquela cena estava de alguma forma ensaiada para minha visita, e as personagens representando o que Angel imaginava que eu queria ver. Angel demonstrando toda paciência no quadro negro e os alunos quietos no papel de aluno, preso esforçado. Estava interessante observar o andamento da aula, porém sabia que aquela poderia ser minha última vez em La Modelo, e que formalmente não conseguiria

\footnotetext{
${ }^{128}$ Angel foi meu principal informante na Catalunha. Escrevi um pequeno relato do meu contato com Angel e as reflexões daí: El soldado del señor: una breve reflexión acerca de un voluntario en una cárcel de Cataluña, ainda no prelo.
} 
autorização para entrevistar seus presos; então quis aproveitar aquele momento, para criar uma situação em que pudesse ouvir um pouco os presos.

Comecei a interagir com Angel e os presos acerca do catalão, e a aula então se tornou um bate papo, os presos tentando compreender quem eu era, o que fazia, e eu perguntando para eles sobre a prisão. As condições da conversa, no meio da aula, em frente do voluntário e da funcionária do sistema não eram as mais adequadas. O pouco que ouvi dos presos foram reclamações quanto a falta de atividades na Modelo e dos prejuízos trazidos pelas transferências (de centros penitenciários) para o andamento dos estudos. Quanto à participação em atividades propostas por voluntários, eles as valoravam positivamente, como uma forma de sair do pátio e manter a cabeça ocupada, voltada para alguma possibilidade no futuro.

Nessa pequena interação, percebi que me sentia muito à vontade conversando com os presos. Talvez porque me sinta como um canal para tantas coisas que eles querem contar. Talvez seja justamente este o tema desta tese.

A aula e o clima descontraído acabam com a entrada do subdiretor Quin e outro educador na sala. Despedi-me dos presos, e, acompanhada de Angel e três funcionários da prisão, atravessei a quadra em direção à saída. Paramos no centro de controle da Modelo. Tento entender como os presos são divididos pelas galerias que irradiam daquele centro. Angel explica que os presos das galerias 4 e 6 não são autorizados a sair da galeria, por serem "presos de risco". Já a galeria 5 abrigava os "destinos", que conforme os presos haviam me explicado anteriormente, era o nome dado aos presos que fazem o trabalho interno da prisão, e por isso tem ampla liberdade de circulação. Estes teriam seu correspondente na figura dos faxinas ou pilotos em São Paulo. Eram atribuições dadas aos destinos, também denominados "presos de confianza":

"realizar algunas funciones en la cárcel como la limpieza de las galerías o repartir la comida, o por tener un destino de confianza y realizar parte del trabajo de los funcionarios como ayudarles en los recuentos abriendo y cerrando celdas, o en la paquetería que entraban las familias, o repartiendo el correo etc."

(Producción colectiva, 2004: 52) 
Aproveitando a presença do subdiretor, agradeci a oportunidade e o consultei sobre a possibilidade de eu voltar a visitar a Modelo, já que uma visita não seria suficiente para alcançar meus objetivos. De antemão, ele respondeu que por ele estava autorizado, mas que dependia da posição da Secretaria de Serviços Penitenciários (SSPRJJ).

Tal resposta já era esperada. O que me surpreendeu foi a hipótese hiperbólica usada por Quin para justificar o controle da entrada de pessoas de fora do cárcere. Segundo ele, não teria como garantir a segurança do pesquisador ou visitante, pois no momento em que este estivesse andando pelo cárcere, um "loco" poderia decidir se pinchar (picar com uma seringa), fazendo voar sangue possivelmente contaminado.

Apesar de alguma verossimilhança com a realidade (na Modelo tem muita droga e muitos presos locos, que não tem nada a perder), o risco de uma situação dessas ocorrer é mínimo. A força simbólica da imagem criada, porém, imensa.

O interessante da alegoria utilizada pelo subdiretor traz representações importantes sobre o contato com o cárcere. Talvez a mais forte delas seja o risco de contaminação física, e sobretudo moral, reatualizado pela existência da prisão, que segrega e isola o perigo.

Angel, que ainda me acompanhava, mostrou-se surpreso com a hipótese do subdiretor, e ao pé do ouvido nomeou bem do que se tratava: "medo institucional". De volta ao pátio de entrada, despedi-me de Angel. Ele ainda ficaria trabalhando, passando a frequência dos alunos para fins de controle institucional.

Essa tarde foi minha primeira e única experiência dentro daquela prisão. Ao final, o "medo institucional" prevaleceu, e depois de muita insistência com a SSPRJJ, fui informada por Jordi que não teria mais acesso à Modelo. Mas poderia acompanhar os voluntários de Brians I e a feminina de Wad-Ras se quisesse.

Certamente a prisão mais "difícil” e emblemática da Catalunha, a Modelo é uma exceção no sistema penitenciário catalão, que deixou há muito tempo de ser modelo. É a única prisão masculina que sobrevive na cidade de Barcelona. Em sua arquitetura histórica e estrutura decadente, espaços sombrios guardam muitas histórias de tortura, violência, droga e sofrimentos. 
A Cárcel Modelo foi a materialização do exercício racional e eficaz da punição do séc. XX. Chega ao século XXI banguela, na espera de sua desativação. Sua estrutura pesada e grande parece incompatível com as novas tecnologias de controle, com um poder em exercício nas câmeras de vigilância, exames, cursos, classificações, banco de dados etc. Os presos de outros centros penitenciários (que em grande parte passaram pela Modelo provisoriamente) se referiam à Modelo como diferente de tudo, e perguntavam-me se já havia estado lá. A impressão que tive era que, para os presos, a Modelo era uma prisão na qual eles tinham mais espaço, e a dinâmica prisional não sofria tanta ingerência dos funcionários prisionais como nos outros centros.

A Modelo é hoje um símbolo de mais de cem anos de história de ineficiência do controle penitenciário catalão. A Generalitat da Catalunya, principalmente a partir do início de 2011, tem fechado as suas portas para a entrada de pesquisadores e para alguns projetos, direcionando o controle externo e concentrando o investimento financeiro e de pessoal nos "novos centros modelos". Sinto que naquela tarde de fevereiro entrei na Modelo por uma das últimas frestas.

\subsection{Apresentação das entidades do campo catalão}

Finalizo esse capítulo caracterizando sucintamente as quatro entidades/projetos que compuseram o meu campo: Justícia i Pau; Fundació Autònoma Solidària; Teatrodentro; e Abrir la Cárcel. Para a descrição das entidades e suas atividades, utilizei somente fontes oficiais: sites das entidades, entrevistas com diretores das entidades ou coordenadores de projetos, e memórias dos projetos- que me foram gentilmente cedidas pelos mesmos.

Reservo as minhas reflexões e questionamentos sobre essas informações para o capítulo seguinte. Neste momento, proponho-me apenas a realizar uma descrição objetiva das entidades, de forma a contextualizar as falas e as análises que se seguirão.

\subsubsection{Justícia i Pau}

a)Título do projeto: Comissió de presons de Justícia i Pau 
b) Apresentação

Justícia i Pau ${ }^{129}$ (Justiça e Paz) é uma entidade cristã que atua na Catalunha desde o ano de 1968, e que tem por finalidade a defesa dos direitos humanos, da justiça social, da paz e desarmamento, da solidariedade e respeito ao meio ambiente. A entidade dedica-se à sensibilização e informação da cidadania, e à pressão política sobre instituições governamentais e partidos políticos por meio de atividades como campanhas públicas, informes, publicações e organização de congressos, seminários, jornadas etc.

\section{c) Histórico}

Nos primeiros anos de existência, durante o período de ditadura, Justícia i Pau teve como prioridade a promoção dos direitos humanos no país. Encabeçou campanhas contra a pena de morte, e denúncias de tortura e abuso policial, além de se comprometer especialmente com a luta pela anistia dos presos políticos e com a defesa do reconhecimento do direito de objeção de consciência.

Em 1987, Justícia i Pau de Barcelona criou uma comissão para se ocupar especificamente com a realidade das prisões da Catalunha: Comissió de presons de Justícia i Pau.

\section{d) Objetivos}

São três os objetivos da Comissió de presons de Justícia i Pau:

1. Contribuir para criar um clima de convivência dentro das prisões e ajudar pessoalmente os presos, a partir de atividades de visitas culturais, educacionais, recreativas e desportivas, e visitas periódicas aos presos doentes.

2. Assegurar permanentemente o respeito pelos direitos humanos e da dignidade dos detentos. A Comissão dedica-se à tarefa de estudar e monitorar a situação das prisões da Catalunha e as condições de vida dos prisioneiros. Quando necessário, dirige-se aos tribunais de justiça ou à administração para exigir mudanças concretas ou investigar responsabilidades.

3. Sensibilizar e informar a opinião pública, para dar a ela conhecimento da realidade da prisão e promover uma cultura menos punitiva e mais respeitosa dos direitos humanos. Para este fim, são organizadas conferências, grupos de discussão,

\footnotetext{
${ }^{129}$ Site: http://www.Justíciaipau.org/, acesso 6/12/2010.
} 
seminários e palestras nas escolas, além da publicação de relatórios e participação em programas de rádio, televisão e outras mídias.

e) Atividades

Os voluntários que compõem a Comissió de presons da Justícia i Pau realizam suas atividades de forma relativamente autônoma, com a supervisão da entidade. Portanto, cada um desenvolve sua própria metodologia para o desenvolvimento das atividades.

Entre as atividades desenvolvidas pela Justícia i Pau estão: o apoio ao ensino dos internos; o suporte psicossocial às demandas dos internos; o entretenimento sociocultural e lúdico; a colaboração em prémios literários e artísticos e outras atividades culturais.

\section{f) Perfil do voluntariado}

Exige-se do candidato ao voluntariado que seja maior de 18 anos, e que apresente currículo e carta de intenções para o trabalho. Em sua maioria, os voluntários de Justícia i Pau são pessoas idosas e aposentadas.

\section{g) Parcerias e convênios}

A entidade tem natureza jurídica de associação de direito canônico da Arquidiocese de Barcelona, e está inscrita no registro de entidades religiosa do Departament de Justícia.

Justícia i Pau obtém financiamento de diversos canais, e procura ser independente: entre seus membros, encontra-se uma pluralidade de opiniões dentro da vontade comum de transformar a sociedade atual. Além da verba dos sócios e doadores particulares, a entidade recebe apoio econômico da prefeitura e Arcebispado de Barcelona, além da instituição financeira UNNIM.

Além disso, a Comissió de presons da Justícia i Pau ingressou em 2005 e 2006 na Taula de participació social, órgão criado pelo Departamento de Justiça para promover a participação social no sistema prisional. Atualmente, participa da rede de organizações voluntárias ou colaborando com a Secretaria de Serviços Penitenciários da Catalunha.

h) Estabelecimento(s) prisional (is) onde se realiza

Visitas aos reclusos do CP Quatre Camins, CP Brians I i II, CP Joves de BCN, CP Dones de BCN, Presó Model e Mòdul penitenciari hospitalari de Terrassa. 


\subsubsection{Fundació Autònoma Solidària (FAS)}

a) Título do projeto

Programa per a la Integració dels Presos (PIP). Além desse, realiza outros dois programas em âmbito da justiça: em meio aberto e nos Centros de Menores.

b) Apresentação

A Fundació Autònoma Solidària ${ }^{130}$ é um órgão da Universitat Autônoma de Barcelona (UAB) que tem como missão contribuir para a construção de uma universidade mais solidária e mais comprometida com a realidade social, pela promoção da participação voluntária da comunidade universitária como instrumento para a integração de coletivos em risco de exclusão.

A entidade é movida pelos valores da solidariedade, tolerância, participação e responsabilidade em direção ao entorno que a envolve. A FAS acredita que se deve tentar fazer alguma coisa pelo preso, "ainda que pareça inútil, ou que não se valorize, ainda que de 100 internos 1 aproveite, há de se fazer"131 (FAS, PIP: 4)

c) Histórico

O projeto teve início no ano de 1995, quando uma pessoa presa expressa a vontade de cursar seus estudos na UAB. Nesse momento, surge o Programa de Suport Pedagògic a Estudiants Empresonats. Em seguida, a FAS percebeu que, mais que um suporte pedagógico, devia-se buscar um suporte moral.

No ano de 1997 a FAS ganha o segundo prêmio outorgado pela Generalitat pelo melhor programa de voluntariado da Catalunha.

Segundo os funcionários, a presença de voluntários mudava a cara dos internos. Para estes, os voluntários são gente de fora, gente da rua, que não os conhecem. Embora saibam que

\footnotetext{
${ }^{130}$ Como fonte das informações aqui elencadas utilizei os documentos Programa Integració Presos (PIP) da FAS e Manual dels Voluntaris/es del PIP., além do site http://www.uab.es/servlet/Satellite/fas1256191998600.html, acesso 08/12/2010.

${ }^{131}$ No original: "podem intentar fer alguna cosa, encara que ens sembli inútil, o que no se'ns valori, encara que de 100 interns ho aprofiti 1, però ho hem de fer"
} 
os presos estão lá por terem cometido algum delito, dedicam 11 meses do ano para "encontrar um motivo que os faça sair do poço", como eles dizem.

\section{d) Objetivos}

A missão do programa PIP é contribuir para a integração social e a reinserção das pessoas privadas de liberdade, principalmente através de atividades de voluntariado que promovem a participação ativa e solidária diante de tal coletivo. "Queremos que, por meio dos voluntários, os presos vejam uma porta aberta à sociedade"132 (FAS, PIP: 1).

São objetivos gerais da entidade:

- dar suporte aos internos em suas atividades acadêmicas;

- organizar atividades de voluntariado que promovam a integração social desses grupos;

- sensibilizar a comunidade universitária sobre os diferentes aspectos da reinserção dos detentos nos centros penitenciários;

- $\quad$ promover a educação em valores.

e) Atividades

No ano de 2010, 25 voluntários da FAS levaram a termo 18 atividades, nas quais foram beneficiadas 132 pessoas. Dessas atividades, 5 se realizaram no CP de Brians, envolvendo 37 pessoas. Outras 13 aconteceram no $C P$ de Dones, e beneficiaram 95 presas.

As atividades são classificadas em duas categorias: atividades acadêmicas (geralmente aulas de reforço escolar e línguas) e de atenção social.

\section{Atividades Acadêmicas}

Segundo a memória do projeto (FAS, 2011) as atividades acadêmicas são destinadas aos presos que precisam reforçar algumas áreas de conhecimento, otimizar suas capacidades, melhorar o desempenho e assumir a responsabilidade pessoal diante do estudo. Dentro de um marco de confiança e comunicação, oferece-se a oportunidade de aprender conteúdos diversos, a fim de melhorar a aprendizagem dos internos.

\footnotetext{
${ }^{132}$ No original "perquè volem que mitjançant els voluntaris vegin una porta oberta a la societat".
} 
Em paralelo às questões específicas de cada voluntário, também se trabalha a falta de motivação de parte dos presos, a falta de confiança em suas próprias possibilidades, a falta de compreensão da matéria, o entendimento dos enunciados, a falta de assiduidade às aulas.

O suporte educacional da FAS abrange o programa de formação básica (série de ciclo do ensino fundamental e secundário), ao programa de ensino superior, e ao programa de formação complementar (catalão, castelhano, informática e preparação para vestibular e módulos de formação).

\section{Atividades de atenção social}

As atividades de atenção social são compostas pela prática de esportes e de atividades sociais e culturais. As atividades esportivas são realizadas na tentativa de promover hábitos e atitudes saudáveis através do esporte, proporcionando, além disso, um espaço de interrelação entre os internos, uma vez que é uma atividade lúdica e motivadora.

As atividades sociais visam atender a necessidade de os internos adquirirem ou reforçarem uma série de habilidades necessárias, tanto dentro do módulo, como visando a sua reinserção na sociedade. Entre essas atividades, destacam-se o trabalho cooperativo, oficinas de habilidades sociais e oficinas de debate.

As atividades culturais buscam promover o interesse pela leitura e a criatividade dos internos, proporcionando-lhes novos conhecimentos. São elas: literatura criativa, teatro e ponto de cruz.

\section{f) Perfil do voluntariado}

São requisitos para exercer o voluntariado pelo PIP: não ter causas judiciais pendentes e não ter qualquer tipo de relação pessoal com os internos do centro penitenciário que realiza o voluntário.

No ano de 2010, a FAS contava com 25 voluntários, sendo 9 em Brians e 16 em Dones. O $\mathrm{CP}$ de Brians fica relativamente perto do campos da UAB, localizado no município de Bellaterra. 
O perfil do voluntariado é claro. A grande maioria são jovens que cursam as faculdades de psicologia, direito, criminologia e educação social. Durante a entrevista de seleção dos voluntários, a entidade valora sua responsabilidade e capacidade comunicativa, de maneira a ser considerado apto para relacionar-se tanto com internos como com funcionário da prisão. Desta maneira, o programa visa assegurar que o voluntário irá adaptar-se corretamente às normas dos Centros Penitenciários. Isso demonstra a preocupação da entidade para que não se tenham em seus quadros voluntários "desadaptados", cujas ações conflitem com as determinações institucionais.

g) Parcerias e convênios

O PIP funciona com o reconhecimento importantíssimo da Direcció General de Serveis Penitenciaris $i$ Rehabilitació, que a cada começo de ano se reúne com a entidade para renovar o convênio para realização de atividades nos centros penitenciários. Além disso, é constante a colaboração com outros programas, fundações e associações. A FAS subvenciona comunicação, material (para as oficinas) e transporte, a partir de uma subvenção anual do Governo.

Em entrevista com Pablo, coordenador dos projetos relacionados ao âmbito da Justiça da FAS, ele revelou que um acordo feito com o Departament de Justícia dava exclusividade à FAS na realização de atividades promovidas por universitários nos Centros Penitenciários da Catalunha, o que evidencia a confiança do Estado na entidade. Periodicamente, são realizadas reuniões de coordenação entre o Departament de Justícia, coordenadores do voluntariado dos centros penitenciários e a FAS.

A FAS reconhece o poder dos funcionários penitenciários na comunicação com os presos. Segundo a memória da entidade, é essencial realizar uma boa coordenação com o pessoal do sistema penitenciário (professores, educadores e funcionários de vigilância), uma vez que eles conhecem as necessidades e demandas dos internos.

h) Estabelecimento(s) prisional (is) onde se realiza

Centre Penitenciari de Brians e Centre Penitenciari de Dones de Barcelona (Wad-Ras). 


\subsubsection{Teatrodentro}

a) Título do projeto

Projeto Teatrodentro - BCN realizado em Barcelona pela associação TRANSformas.

b) Apresentação

Cabe marcar de início duas diferenças deste projeto em relação aos apresentados anteriormente. A associação TRANSformas não está elencada como entidade voluntária ou colaboradora do Departament de Justícia, ainda que tenha convênio com diversas Secretarias da Generalitat (Justícia, Cultura, etc.). Além disso, as pessoas que promovem o projeto não são tecnicamente voluntárias, mas profissionais que recebem para tanto, apesar do trabalho envolver estagiários voluntários e o público da sociedade civil.

Consciente das especificidades de cada um dos quatro projetos que compuseram meu campo, e, consequentemente, das limitações nas comparações entre eles, optei por incluir o Teatrodentro no recorte do campo. Essa escolha foi motivada pelo impacto social do projeto (já o conhecia desde o Brasil) e pela vontade de conhecer outros modelos de intervenção.

TRANSformas ${ }^{133}$ é uma associação, um projeto e um grupo humano que trabalha com Teatro Social e com o Teatro do Oprimido, dirigidos ao desenvolvimento da pessoa e da comunidade.

\section{c) Histórico}

O projeto se origina em outubro de 2004, quando a associação teatral TRANSformasBarcelona, a Cooperativa Estia ${ }^{134}$-Milão e Lieux fictifs ${ }^{135}$-Marselle começam o Projeto Europeu Grundvig 4, denominado TeatroDentro: educación no formal en prisiones. Durante o primeiro ano, desenvolve-se uma reflexão comum às três entidades sobre o efeito de empregar o teatro ou o cinema no entorno penitenciário. No segundo ano, é desenhada a formação europeia "Teatro y cine: educación no formal en prisiones" com convocatórias em Milão, Marselle e Barcelona.

\footnotetext{
${ }^{133}$ Como fonte das informações aqui elencadas utilizei os documentos Fontes "Teatro en cárceles", s.d. de Thomas Louvat e o site http://www.trans-formas.com/pag_teatrodentro.asp

${ }^{134}$ www.cooperativaestia.it, acesso 13/06/2011.

135 www.lieuxfictifs.org, acesso 13/06/2011.
} 
Em março de 2005, TRANSformas começou os contatos com a Dirección General de Penitenciarias de la Generalitat da Catalunha para iniciar um grupo teatral no Centro Penitenciário de Quatre Camins. Após 4 meses de fase piloto, o projeto foi implementado por tempo indeterminado no Centro.

De acordo com a grupo, a confiança do Departament de Justícia de la Generalitat no trabalho desenvolvido pela equipe TeatroDentro-Bcn, possibilitou uma nova ramificação do projeto, com a formação de um grupo teatral de mulheres na prisão de Wad-Ras, como uma das ações do Proyecto Eureka, em 2007. No mesmo ano, o Teatrodentro integrou às suas atividades uma associação de fotojornalismo autônomo de Barcelona (coletivo RUIDO), promovendo reflexões sobre o espaço reservado à arte nas prisões.

Atualmente (2011) o grupo segue com projetos de teatro e vídeo no Centro Penitenciário de Quatre Camins e Wad-Ras.

\section{d) Objetivos}

O objetivo geral do projeto é desenvolver a intervenção no âmbito penitenciário por meio de metodologias artísticas/visuais. Com a finalidade de:

$\checkmark$ minimizar o dano que a privação de liberdade produz no individuo;

$\checkmark$ favorecer o processo de inserção e a educação continua da população penitenciária;

$\checkmark$ consolidar Teatrodentro-Barcelona como gerador de oportunidades, espaço ativo e ferramenta útil e prática para responsabilizar o individuo sobre sua vida;

$\checkmark$ criar um canal de comunicação entre prisão e sociedade civil e gerar compromisso comunitário.

São objetivos em relação aos beneficiários diretos do projeto (pessoas presas no Centro Penitenciário Quatre Camins e seus trabalhadores):

$\checkmark$ promover as competências pessoais da população reclusa;

$\checkmark$ facilitar e apoiar o processo de reabilitação social e relacional dos detentos, para que o indivíduo não sofra um choque ao se encontrar em um mundo onde terá de retomar as rédeas de seu presente e futuro; 
$\checkmark$ estimular o interesse artístico dos participantes;

$\checkmark$ desenvolver a capacidade de expressão e comunicação dos participantes;

$\checkmark$ estimular nos participantes a observação e análise da realidade interior e exterior, e, a partir daí, a expressão e comunicação de ideias, histórias e problemáticas.

Constituem ainda objetivos em relação aos beneficiários indiretos (instituição penitenciária e todos os seus funcionários, e a sociedade exterior em seu conjunto):

$\checkmark$ favorecer a comunicação interior/exterior, contribuindo para desmontar os estereótipos e preconceitos existentes na sociedade livre sobre as pessoas presas e a vida prisional;

$\checkmark$ produzir projetos visuais de qualidade, realizados pelos próprios participantes, criando novos espaços de produção e difusão cultural;

$\checkmark$ dar visibilidade aos trabalhos produzidos através de uma rede de difusão.

e) Atividades

TRANSformas trabalha atualmente em quatro linhas diferentes, utilizando sempre o teatro como ferramenta de mudança social: Oficinas de intervenção; Formação; Grupo de criação coletiva; e Impacto social.

O Teatrodentro desenvolve, nas tardes de segunda a sexta, diversas atividades em Quatre Camins, dentre as quais: dinâmicas de grupo, interpretação, improvisação e exercícios teatrais, formação técnica de luz e som, supervisão psicológica do grupo. Cada uma dessas atividades é conduzida por um formador diferente.

As edições anuais do Teatrodentro contavam com presos já participantes do projeto e incorporavam novos membros. Inicia-se com aulas de formação teatral, para passar pela construção coletiva da peça, e então, para a tournée, que consistia em apresentar a peça na própria prisão para o público de fora e familiares, e também em outros Centros Penitenciários da Catalunha para os outros presos e público externo (sempre em sessões separadas). 
Os grupo de beneficiários diretos (aproximadamente 30) que participaram da formação teatral são envolvidos em todas as etapas do processo criativo: trabalho autoral, construção de cenografia e indumentária, criação da música e interpretação da mesma.

Além das obras teatrais, nos últimos anos, Teatrodentro tem produzido vídeos, curtas e material documental do grupo, que inclusive dão base para construção do roteiro da peça.

TRANSformas também é responsável por promover o Festival In-out, que ocorre simultaneamente dentro e fora da prisão, permitindo ao presos um espaço de cinema ou teatro, apostando no poder transformador que essas expressões artísticas comportam. Diversas peças tiveram seção de exibição nos Centro Penitenciários durante o festival de 2010. Dentre as quais "Allò que dic allò que faig" ${ }^{136}$ apresentada pela companhia de teatro-cinema da prisão de Quatre Camins, estreou e realizou uma turnê por diversos centros penitenciários.

\section{f) Perfil do voluntariado}

O projeto Teatrodentro é realizado não somente por voluntários, mas por profissionais contratados para dar formação e montar a peça ou vídeos do grupo. Além do conhecimento técnico, requer-se do formador uma sensibilidade social para o tema do encarceramento. $\mathrm{O}$ grupo acolhe também estudantes que realizam estágio voluntário com o grupo.

g) Parcerias e convênios

O Teatrodentro-BCN faz parte do Proyecto Europeo TeatroDentro: educación no formal en prisiones, que é desenvolvido de forma paralela em três cidades europeias:

- Milão (Itália): desenvolvido pela cooperativa ESTIA (Societá Umanitaria), que realiza Teatro (prisão de Bollate) e cinema (prisão de San Vitorre).

- Marsella (França): com Asociación Lieux-Fictifs, que desenvolve Cinema (prisão de Les Baumettes)

- Barcelona (Espanha) Asociación TRANSformas de teatro y fotografia (Cárcel de Quatre Camins e Wad-Ras)

136 "O que digo o que faço". 
As três entidades foram contempladas pelo programa Sócrates da União Europeia. Este programa patrocinou a constituição de uma equipe internacional, que por dois anos trabalharia em pesquisa e produção sobre a educação não formal nas prisões através do teatro e cinema.

Os projetos do TRANSformas são realizados em conjunto com diferentes grupos, por demandas específicas de Prefeituras, Planos de desenvolvimento Comunitário, Associações. Respondem também a interesses e reflexões de membros do grupo.

h)Estabelecimento(s) prisional (is) onde se realiza

Cárcel de Quatre Camins e CP Dones de BCN (Wad Ras)

\subsubsection{Abrir la Cárcel}

a) Título do projeto

Abrir la Cárcel

b) Apresentação

Abrir la Cárcel $^{137}$ surge de uma iniciativa de um grupo de estudantes e professores de Universidades da Catalunha, principalmente Universitat de Barcelona (UB), membros da Asociación contra la cultura punitiva y de exclusión social e da Asociación Espai de Treball Universitari, entidades que representaram formalmente esta iniciativa.

O projeto atende a duas finalidades principais: integrar o maior número de pessoas dentro das possibilidades que oferece a Universidade, e por outro lado, desenvolver a necessidade de abertura da Universidade à sociedade, em particular à prisão.

\section{c) Histórico}

O projeto se iniciou em setembro de 1999, e teria a duração de um ano. Iniciou-se como experiência piloto, de seis seminários com duração de um mês cada um. Porém, ainda na terceira sessão, o projeto foi encerrado.

d) Objetivos

\footnotetext{
${ }^{137}$ Principal fonte: Abrir la cárcel. Memória del proyecto, 1999.
} 
O projeto teve como finalidade essencial a reprodução, no interior da prisão, de um "espaço de classe" (aula) em que se trabalha na Universidade, impulsionado pela lógica de que "se os presos e presas não podem aproximar-se da Universidade, esta deve aproximarse da prisão".

O objetivo era desempenhar no cárcere um importante serviço público, um projeto cultural que pudesse romper o tradicional isolamento que caracteriza toda instituição fechada em geral, e a prisão em particular. Tratava-se de pesquisar e constatar que efeitos podia provocar uma experiência similar com um coletivo de pessoas que, como os presos e presas, experimentariam vivências diferentes baseadas na criação de um "espacio de trabajo, de debate, de crítica, en suma, de libertad" (Abrir la Cárcel, 1999: 2).

\section{e) Atividades}

300 pessoas, entre presos e presas, se inscreveram para a atividade. Porém, para viabilizála, formaram-se dois grupos, com cerca de 40 pessoas e de caráter misto, para a primeira edição dos seminários. A ideia era repetir os seminários de forma a atender todos os inscritos.

Para o ano de 1999, foram programados seis seminários (com sessões semanais e de duração mensal): Estado e Direitos; Introdução à Psicologia Social; Delito e Meios de Comunicação; Meio-ambiente; Música; e Literatura.

f) Perfil do voluntariado

O perfil das pessoas que compuseram o Abrir la Cárcel era basicamente universitário, já que o grupo era formado por professores e alunos da Universitat de Barcelona.

g) Parcerias e convênios

O projeto Abrir la Cárcel foi elaborado a partir de uma Comissão de Trabalho no âmbito da Asociación contra la Cultura Punitiva y de Exclusión Social. Foi aproveitada a experiência de outra associação (Espai de Treball Universitari), que já vinha desempenhando atividades em uma prisão catalã.

Em seguida, o projeto foi submetido ao Departamento de Derecho Penal y Ciencias Penales da Universidad de Barcelona, que expressou todo seus apoio ao desenvolvimento 
do mesmo. Além da ajuda econômica, o apoio da UB tinha uma importância simbólica para grupo.

h) Estabelecimento prisional onde se realizou

Centre Penitenciari de Brians. 


\section{CAPÍTULO 6 \\ PRISÃO E VOLUNTARIADO NA CATALUNHA}

Neste capítulo, apresentarei algumas reflexões advindas da pesquisa de campo realizada na Catalunha. No período de dez meses de estágio, além de ter participado de inúmeros seminários, encontros, cursos, e visitado seis diferentes Centros Penitenciários, realizei entrevistas com coordenadores de projetos, voluntários, presos, entre outros envolvidos com o sistema penitenciário local. Os temas e categorias a que recorro neste capítulo foram construídos a partir dessas experiências nos campos acadêmico, burocrático-estatal e prisional catalães.

Iniciarei o capítulo com uma apresentação breve da tradição do voluntariado na Catalunha, e das transformações dos movimentos de presos na região no decorrer das últimas décadas. Em seguida, caracterizarei o voluntariado penitenciário catalão, situando a função do voluntário no funcionamento do sistema prisional, e apresentando as motivações dos presos e representações de voluntários envolvidos nos projetos de intervenção no cárcere.

Analisarei ainda a relação entre estabelecimento prisional e entidades de voluntário, elencando algumas das demandas dos Centros Penitenciários e propondo uma análise dos caminhos para a proposição de atividades no cárcere. Nesse sentido, discuto como a seleção e controle por parte das entidades que atuam no cárcere afetam o tipo de dinâmica a ser proposta pela sociedade civil, e os perigos da normatização da dinâmica prisional pelo Estado. Ao final, comparo diferentes estratégias de resistência, a partir da trajetória de dois grupos do campo catalão.

\subsection{Sociedade civil e prisão na Catalunha}

Inicio este capítulo com o tema do envolvimento da sociedade civil catalã nas questões prisionais. Primeiro, retomo a tradição do voluntariado e cito algumas transformações do movimento a favor dos presos na Catalunha. Em seguida, explicito algumas características da organização de intervenções penitenciárias na região, passando por marcos legais e institucionais, e pela análise da formação oferecida ao voluntário.

\subsubsection{Voluntariado na Catalunha}

Ainda que o voluntariado seja um fenômeno constatável a nível global, na Catalunha ele se 
reveste de uma dimensão social e simbólica muito particular. Um dos principais capitais sociais da Catalunha é o associativismo. Esse traço tão forte da cultura catalã manifesta-se na tradição das pessoas se organizarem em volta de entidades, e desde aí promoverem atividades culturais, esportivas e lúdicas, além de incontáveis festas populares.

Esse espírito de associação também se reflete na mobilização para o trabalho voluntário. Não por acaso Barcelona foi escolhida como sede do primeiro Congresso do Voluntariado no ano de 1995, que entre as suas conclusões destacou o papel do voluntário no atendimento de necessidades sociais.

No preâmbulo da lei ${ }^{138}$ que cria o Institut Català de Voluntariat (Incavol), o voluntariado aparece como elemento essencial para configuração da identidade catalã; fruto da história de sobrevivência e consolidação da Catalunha como um "país"139 responsável pela criação e desenvolvimento de muitas entidades cívicas e solidárias.

De acordo com o marco legal supracitado, o voluntariado compreende um:

"conjunto de pessoas que efetuam uma prestação voluntária e livre de serviços cívicos ou sociais, sem contraprestação econômica, no marco de uma organização estável e democrática que comporte em compromisso de atuação a favor da sociedade e da pessoa" 140

A finalidade do Incavol era promover o voluntariado na Catalunha, por meio de cursos de formação, gestão de subvenções e suporte legal e administrativo. A partir de 1997, o Servei Catalã de Voluntariat assumirá essa missão de organizar o voluntariado, e de aproximar entidades que realizam projetos de voluntariado dos cidadãos que desejem se informar ou participar desses projetos.

Já a Subdirecció General d'Associacionisme i Voluntariat do Departament de Benestar Social i Família assessora nas atividades de voluntariado em diversos temas: jurídico, informática, projetos, formação, estratégias de gestão, página web, etc.

\footnotetext{
${ }^{138}$ Lei 25/1991, já revogada.

${ }^{139}$ Catalunha é uma das Comunidades Autônomas que compõem a Espanha, porém é muito comum que seus cidadãos se refiram a ela como um país, apontando para uma tendência independentista.

${ }^{140}$ Tradução livre. No original: "El voluntariat és el conjunt de persones que efectuen una prestació voluntària $i$ lliure de serveis cívics o socials, sense contraprestació econòmica, dins el marc d'una organització estable i democràtica que com-porti un compromis d'actuació a favor de la societat $i$ de la persona"
} 
A importância da prática do voluntariado na Catalunha reflete-se nos inúmeros marcos legais ${ }^{141}$ que disciplinam a matéria: uma série de resoluções, decretos e acordos tem como tema o voluntariado. A partir desse conjunto normativo, foi constituída uma rede composta por Associações, Comissões e Planos de ações voluntárias.

No contexto de crescimento quantitativo e qualitativo da atuação das Organizações nãogovernamentais em temáticas sociais no decorrer das últimas décadas, o marco geral do associativismo na Catalunha é reafirmado. Tal aumento pauta-se na percepção contemporânea de que a sociedade civil é corresponsável, juntamente com o Estado, pela gestão dos problemas sociais. Essa releitura participativa da sociedade impactou o lugar ocupado pelas entidades de voluntariado no espectro social, em especial o movimento de presos, conforme analisarei a seguir.

\subsubsection{As transformações do movimento a favor dos presos}

Para refletir acerca das ações da sociedade civil no sistema prisional, é necessário inseri-las nas condições históricas e sociais que possibilitaram sua emergência. A partir de breves referências da história recente da Catalunha, tentarei contextualizar as mudanças em torno do movimento de defesa dos presos, o qual emerge na década de 70 do século passado com finalidades explicitamente políticas, e chega a este século sob a forma de voluntariado com fins basicamente assistencialistas.

A recente história penitenciária espanhola foi profundamente marcada pelo sistema repressivo franquista, que perdurou de 1939 até a morte de Franco em 1975. No período de transição democrática, a partir do ano de 1976, uma grande crise assola o sistema penitenciário catalão. Os presos organizam uma série de protestos: motins, greves de fome, autolesões. Com esses atos eles não só buscavam denunciar as condições de vida na prisão, mas antes de tudo reclamavam a anistia total e geral, ou seja, extensão da anistia política aos presos considerados "comuns" (que logo se autonomeariam "sociais").

É nessa época que os presos, familiares e apoiadores começam a se organizar em torno de entidades de defesa dos direitos, tais como a Coordinadora de Presos en Lucha (COPEL);

${ }^{141}$ http://www.voluntariat.org/ElvoluntariataCatalunya/Legislaci\%C3\%B3.aspx, acesso 3/11/2011. 
Asociación de Familiares y Amigos de Presos y Ex Presos (AFAPE); a Asociación para el Estudio de los Problemas de los Presos (AEPPE).

Beiras (1999: 10) considera o ano de 1989 como ponto de inflexão em termos de endurecimento da política penitenciária, com o surgimento de uma cultura da excepcionalidade, justificada em grande parte pela luta contra os grupos terroristas na Espanha. Nesse ano, foram criados os ficheros especiales -FIES: uma base de dados que armazena informações dos presos tidos como perigosos ao sistema. A inclusão de seu nome no ficheiro tem um impacto negativo na vida do preso FIES, que passa ser sistematicamente controlado pelo sistema prisional. Estão previstos nestes casos o isolamento celular, revistas, censura de correspondência etc.

Em 1990 foi criada a Plataforma de Integración de los Movimientos Sociales de Apoyo a Presos y Presas, composta por diversas entidades tradicionais de apoio ao preso (Pastoral Carcelaria, Justícia i Pau, Coordinadora contra la Marginació Social de Cornellà) com o objetivo não só de reformas positivas, mas da superação definitiva da reclusão institucional.

Godói (2010), com o objetivo de mapear as redes que conectam cárcere e sociedade na Catalunha, percorre um pouco a história dessas instituições, como forma de compreender o fenômeno recente de estruturação de uma rede dinâmica do terceiro setor que insere o voluntariado no interior da prisão.

Durante sua investigação em Barcelona, Godói acompanhou as assembleias da Coordinadora contra la Marginació de Cornellà. Apesar dessa entidade não ser objeto de análise dessa pesquisa ${ }^{142}$, retomar sua história pode contribuir para a compreensão de como as entidades da sociedade civil compõem as mudanças ocorridas nos últimos 30 anos no campo prisional da Catalunha.

Uma das principais informantes de Godói foi Manola, que por muitos anos presidiu a Coordinadora. Em 2002, quando ela resolve se reaproximar da entidade, percebe que

\footnotetext{
${ }^{142}$ Apesar de constar da pesquisa exploratória, optei por não aprofundar a análise da entidade Coordinadora de Cornellà já que não obtive retorno dos contatos realizados; e tinha conhecimento do trabalho de Godói sobre a mesma.
} 
estavam em disputa dois projetos acerca dos rumos da instituição. Um deles era sustentado pelos militantes dos anos 80 , que queriam a manutenção do perfil político da entidade. $\mathrm{E}$ um outro, mais conservador, defendido por um setor de senhores e senhoras religiosas (Godói, 2010: 125).

A disputa que se iniciou nos anos 80 quanto aos fins da entidade está longe de ser resolvida. Nos últimos anos, a Coordinadora estabeleceu uma série de parcerias e convênios com instituições públicas e privadas. Essa escolha foi interpretada de maneira distinta pelo grupo:

"Para alguns, avanços como esses representavam a profissionalização e um salto de eficiência para os projetos da entidade - um ganho de capacidade de mobilização; para outros, tais parcerias representavam um refreamento na capacidade de denúncia e reivindicação do coletivo - imobilização. O conflito não se dava somente no nível da concepção de entidade, tinha implicações muito concretas."

(Godoi , 2010: 104)

A vontade, manifestada pela direção da Coordinadora, de substituir o nome da entidade por algo mais propositivo aponta para uma definitiva mudança no foco de atuação da entidade. Segundo Godói (2010: 105), a entidade busca agora um nome que remeta a um futuro inclusivo e pacífico, deixando para trás o viés combativo e social que marcou a história do grupo, e mesmo a escolha de seu atual nome.

A descrição de Godói aponta para uma mudança profunda em uma das entidades civis importantes da Catalunha, com a substituição de um perfil originariamente políticoreivindicativo por um outro, de viés voluntário-assistencial. Esta mudança não está rescrita ao grupo de Cornellà, mas representa uma tendência das entidades atuantes no cárcere, que Beiras (2010) diagnosticou como a passagem de uma ação sócio-política dos grupos de pressão para outra, de caráter sociocultural.

A escolha entre atender às demandas urgentes dos presos (reforçando o caráter assistencialista da ação) ou atuar criticamente, tendo em vista a dimensão política do emprisionamento, vem sendo objeto de debate na Criminologia já há algum tempo, e ocupa o centro do debate na presente tese. 
Em entrevista ${ }^{143}$ para esta pesquisa, o criminólogo Iñaki Rivera Beiras (membro do Observatori del Sistema Penal i els Drets Humans (OSPDH) da Universitat de Barcelona e idealizador do projeto "Abrir la Cárcel") afirmou que no marco da sociedade civil existe uma diversidade de grupos que atuam no cárcere. Ainda segundo ele, grande parte destes grupos não questiona suas práticas, assumindo a incumbência de auxiliar na "terapia penitenciária", e sustentando a ideologia correcionalista.

\subsubsection{Marcos do Voluntariado penitenciário catalão}

O sistema penitenciário da Catalunha é composto por 15 Centos Penitenciários. A Secretaria de Seveis Penitenciaris, Rehabilitació i Justícia Juvenil (SSPRJJ), a quem compete administrar a Execução Penal na Catalunha, conta com dois tipos de entidade: as colaboradoras e as voluntárias. Ambas exercem um papel muito semelhante nos Centros Penitenciários e em relação à SSPRJJ, diferenciando-se apenas pelo fato de que o convênio com as entidades colaboradoras prevê a destinação de uma verba para a realização das atividades, o que não ocorre com as voluntárias.

Atualmente, a SSPRJJ conta com aproximadamente mil voluntários, agrupados em 110 entidades $^{144}$. O programa Marc de Voluntariat, da SSPRJJ, estabelece princípios e normas de atuação para as entidades de voluntariado.

A pessoa que deseja ser voluntária deve fazer parte de uma entidade pública ou privada, autônoma e sem fins lucrativos, que tenha o objetivo de trabalhar para os outros na melhoria da qualidade de vida. Para o exercício do voluntariado, as entidades devem estar constituídas legalmente e cadastradas no Registro de Associações da Generalidade da Catalunha.

As entidades de voluntariado devem apresentar um projeto de intervenção, que será validado pela SSPRJJ, e que deverá conter: descrição da entidade, objetivos, nome dos voluntários, metodologia de trabalho, previsão de dias e horários, espaço a ser utilizado para as atividades etc. São previstos como tipos de prestação voluntária na prisão:

\footnotetext{
${ }^{143}$ Barcelona, julho de 2011.

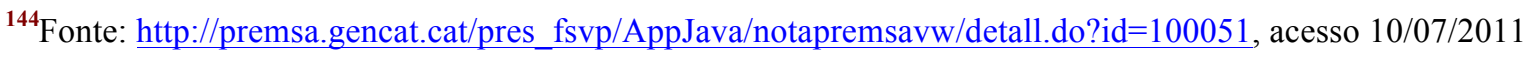


assistência jurídica, animação sociocultural, promoção da saudade, formação, prática de esportes, acompanhamento educativo, acompanhamento na comunidade.

Dentro desse marco, o voluntariado é organizado a partir da articulação de três instituições: a SSPRJJ, as entidades de voluntariado e o centro penitenciário. As duas primeiras estudarão e planejarão, de maneira conjunta, as ações de voluntariado, que se devem ajustar às necessidades identificadas e acordadas previamente com o centro penitenciário.

A relação da entidade com o Centro Penitenciário depende da entidade, mas também das especificidades de cada centro. Segundo Pablo, da FAS, Brians I é um centro grande, e tem um coordenador das atividades de voluntariado, funcionário responsável por tratar com as entidades. Logo, a negociação é mais burocrática, institucional, e, consequentemente, mais difícil. Já a penitenciária feminina onde a FAS também realiza atividades é um centro pequeno, o que facilita a comunicação entre voluntariado e pessoal penitenciário.

\subsubsection{Formação do voluntário penitenciário}

É exigido ${ }^{145}$ do voluntário penitenciário a realização de curso de formação oferecido pela SSPRJJ, denominado "Intervenció en centres penitenciaris des del voluntariat” com duração de 20 horas, divididas em três módulos:

$>$ Enquadramento legal da intervenção em âmbito penitenciário, que tem como conteúdo direito de execução penal (modalidades e funções da pena, programas de reabilitação, classificação dos internos) e normativa do voluntariado;

A ação do voluntariado: princípios gerais de atuação. Este módulo propõe uma reflexão sobre o sentido do voluntariado e sua relação com a sociedade;

> Habilidades básicas para o exercício do voluntariado, cujo conteúdo se aproxima dos livros chamados de autoajuda, abordando técnicas de comunicação, manejo das emoções, habilidades cognitivas, ser integral.

\footnotetext{
${ }^{145}$ Algumas entidades, como a Fundació Autônoma Solidaria, oferece curso de formação próprio que substitui o da SSPRJJ.
} 
Além da formação dos voluntários, o curso cumpre com a importante função de pautar os limites de sua atuação. Numa entrevista realizada pelo Departament de Justícia $(2011)^{146}$, uma voluntária revela essa função implícita do curso:

"voluntária: -O voluntário deve ter muito claro até aonde pode chegar com o voluntariado, porque os presos podem demandar dele uma série de interações que ele sabe que não pode fazer.

Departament de Justícia -E como sabe que não pode fazer aquilo que the demandam?

voluntária:- Porque fiz um curso de voluntário penitenciário"

Outra voluntária, que também realizou o Curso oferecido pelo Departament de Justícia, aponta para a necessidade do voluntário tomar contato com as dinâmicas internas da penitenciária, que não são ensinadas no curso e só são apreendidas no dia-a-dia prisional.

Para tanto, ela recomenda que o governo designe um trabalhador social que acompanhe o voluntario, introduzindo-o nos códigos da prisão. Apesar de haver um funcionário destinado exclusivamente para esta função, ele não está presente no domingo, dia em que a voluntária assiste aos presos (Departament de Justícia: 2011).

Nesse sentido, ela ainda sugere que o Curso do Voluntariado apresente situações concretas, que ajudariam na preparação para o cárcere e na prevenção de possíveis situações problemáticas que possam surgir na dinâmica prisional.

No Manual do Curso (SSPRJJ, 2007:59), estão elencadas três "ferramentas chaves para a pessoa voluntária": formação, supervisão e avaliação. Por meio desses mecanismos, e com a justificativa (legítima) de apoiar a prática voluntária, o Departament de Justícia coloca em exercício seu poder na produção de um saber específico. Formar, supervisionar e avaliar são ações que nos remetem à disciplina escolar, cujas práticas são basicamente a transmissão de um conteúdo, a vigilância da leitura que será feita dele, e por fim, a realização do exame.

${ }^{146}$ Experiències de tres voluntaries- Catalunya. A publicação é em catalão, traduzi livremente os trechos citados para o português. 
Não se encontra no texto nenhuma análise da prisão em sua dimensão social, histórica ou política. A problemática da prisão é construída a partir da perspectiva individual, tanto do preso como do voluntário; a aposta institucional é no sentido de ajudar, tanto a um quanto a outro, no manejo de suas emoções e no desenvolvimento de habilidades sociais.

Uma breve análise da bibliografia ao final do Manual reflete o tipo de ideologia ali implícita. As obras apontam para o tipo de saber que o voluntário deve manejar. Nesse sentido, seus títulos são reveladores: Autoestima, cómo mejorar la propia imagen. Sedueixte per seduir. Viure i educar les emocions, Encrucijada emocional, Manual de evaluación $y$ entrenamiento en las habilidades sociales, Enseñar a convivir no es tan difícil etc. Dentre os dezenove títulos, não há uma única ocorrência das palavras prisão, preso, sistema de justiça ou sociedade.

O voluntário tem o potencial de formular um discurso acerca da prisão, a partir de seu olhar externo. Na maioria das vezes, ele tem seu primeiro contato com o cárcere quando dá início ao voluntariado. A estratégia da administração prisional de restringir desde logo a autonomia reflexiva do voluntário, preparando seu olhar e dando-lhe chaves interpretativas, é uma forma de reafirmar a verdade do discurso institucional acerca da realidade prisional.

De acordo com a SSPRJJ (2007), a ação voluntária nas prisões deve ser um veículo de transmissão de valores. A verdade é construída na medida em que se interpreta a realidade e em que se escolhem os enunciados e a linguagem adequados para tanto. Nesse sentido, não há linguagem neutra, porque a interpretação sempre pressupõe uma escolha. Na vontade de proferir um discurso verdadeiro, o que está em jogo é desejo e poder (Foucault, 1996: 20).

As chamadas práticas discursivas tem a função de determinar o que e como pode ser dito, estabelecendo as maneiras e possibilidades de compreender o mundo. A hegemonia do saber institucional na leitura da realidade prisional tem como consequência a construção de uma verdade acerca do preso, e a naturalização da solução punitiva.

\subsubsection{Espaço de troca e encontro: Taula de participació social}


Taula de Participació Social ${ }^{147}$ (TPS) é um espaço de encontro das entidades colaboradoras e voluntárias que atuam no cárcere. Foi criado em 2009, fruto da necessidade de estabelecer canais de comunicação entre entidades que trabalham no cárcere, permitindo o intercâmbio e transmissão de informações.

A TPS atua como órgão consultivo e de relação entre o Departamento competente para matéria de execução penal e as entidades que trabalhem nos processos de reinserção social na Catalunha, com a finalidade de promover a participação cidadã.

A TPS é um espaço de interlocução de 90 entidades sociais da Catalunha que trabalham em âmbito penitenciário, desenvolvendo serviços de reabilitação pessoal e reinserção social. Ela é composta por representantes da Administração Prisional (SSPRJJ), além de seis entidades colaboradoras e quatro voluntárias, que representam o coletivo das entidades que realizam trabalho nos cárceres e compõem a "parte social da Taula"

Alguns princípios da TPS definem suas pautas de atuação. Talvez o principal deles, ressaltado em diversos momentos nos textos que regulam sua atuação, seja o comprometimento (e submissão) da Mesa aos interesses estatais. Tais normativas estabelecem que a atuação da TPS deve ser guiada pela finalidade de reinserção dos internos, fim que deve ser buscado conjuntamente pela Direcció General de Serveis Penitenciaris e entidades colaboradoras e voluntárias.

Ademais, as entidades devem reconhecer a titularidade das tarefas do Departament de Justícia, e assumir o compromisso de atuar sempre de acordo com a normativa aprovada pelo mesmo.

Esse discurso oficial, que coloca as entidades como auxiliares do Estado, foi reproduzido por diversos informantes durante a pesquisa. Como na fala de Pablo, da FAS, para quem o trabalho realizado pelos voluntários é complementar à intervenção de tratamento dos Centros Penitenciários que fomenta a reinserção

\footnotetext{
${ }^{147}$ Mesa de Participação Social. Informações: http://www20.gencat.cat/portal/site/Justicia/, acesso 4/10/2011. ${ }^{148}$ No ano de 2011 compunham a parte social da TPS: l'Associació Andròmines, l'Associació Cedre, APIP, Creu Roja Catalunya, DINCAT, Fundació Ared, Fundació Autònoma Solidària, Fundació l'Heura Tarragona i INTRESS.
} 
São funções da TPS: a) levar informação e abrir os processos de participação com a representação da parte social da Taula em todos os aspectos estratégicos de política penitenciária relevantes para a sua atuação; b) avaliar o funcionamento e fazer propostas de melhoria dos circuitos e canais de comunicação na relação de colaboração entre Departament de Justícia e entidades; c) propor estratégias conjuntas para difundir a dimensão social e reabilitadora da política penitenciária.

Uma das mais recentes ações da TPS foi uma campanha de sensibilização da opinião pública denominada "Obrim la porta a la rehabilitació" ${ }^{149}$, veiculada no segundo semestre de 2011. Por meio de um vídeo com depoimentos reais, a TPS busca conscientizar a sociedade que a reabilitação não só é possível mas o melhor caminho para evitar a reincidência e ter mais segurança cidadã.

Em dezembro de 2010, fui a uma reunião da TPS no CEJFE (Centre d'Estudis Jurídics $i$ Formació Especialitzada) em Barcelona. Era a última do ano, e agregou representantes de algumas das 95 entidades que realizam trabalhos no cárcere, entre colaboradoras e de voluntariado. Representantes das instituições que compunham a TPS e da SSPRJJ realizaram uma avaliação da gestão 2010 e eleição para 2011.

O plano estratégico de 2010 previa melhoras na rede e integração entre as entidades, no atendimento e na opinião pública. Na avaliação da TPS, os objetivos foram executados a partir da melhora na formação dos voluntários, criação de rede virtuais entre as entidades, e a campanha "Obrim la porta a la rehabilitació".

As demais falas abordaram as dificuldades no processo de reabilitação de presos, em especial dos imigrantes, pessoas sem vínculo familiar ou social, e/ou dependentes de drogas.

Achei importante recuperar um resumo do Plenari d'Entitats da TPS (Taula de participació social, 2007) realizado em junho de 2007, também no CEJFE, com a

\footnotetext{
149 “Abrir a porta à reabilitação” http://www.youtube.com/watch?v=_K0uOAwqF0o, acesso 11/10/2011.
} 
participação de representantes de mais de 30 entidades e 40 voluntários. Naquela ocasião, buscava-se uma reflexão conjunta de caráter estratégico no marco de consolidação da TPS. A discussão centrou-se em três temas: interlocução com o Departament de Justícia, necessidade de gerar uma opinião social favorável e o desejo de melhorar a intervenção

Os posicionamentos daí advindos são representativos das formas de atuação das entidades colaboradoras e voluntárias da Catalunha, e sua relação entre os diversos atores da execução penal (Departament de Justícia, voluntários, presos, sociedade). Por isso, reproduzo abaixo algumas ideias chaves presentes no documento, originadas a partir de respostas dos voluntários (TPS, 2007):

- São meios para o Departament de Justícia apoiar a TPS: proporcionar confiança mútua, qualidade de serviços, pontos de diálogo, itinerários diferenciados para presos com "necessidades diferentes", aumento da sensibilidade dos funcionários do sistema e das possibilidades legais de atuação.

- A construção de uma opinião pública favorável à reabilitação e reinserção do preso, que deverá ser realizada por intermédio dos meios de comunicação, debates abertos, do reforço na comunidade sobre a necessidade de integração do preso, do respeito ao mandato constitucional da reinserção etc.

- A melhora na qualidade da intervenção das entidades pode ser alcançada pelo rigor metodológico, qualificação e profissionalização dos voluntários; sistematização das práticas e padronização; busca de recursos; e ainda, consolidação de um discurso comum, que permita uma presença coesa, ativa e competente, aliada a uma estratégia com objetivos a largo prazo.

Em 2009, a Taula de Participació Social produziu um outro material: Què diem... les entitats de voluntariat?, a partir de questionários respondidos por 24 entidades. Foram apontadas as dificuldades na realização do trabalho voluntário, dentre as quais: falta de espaços adequados para atividades, pouca agilidade na concessão de permisos (autorizações), rigidez dos horários do Centro Penitenciário, falta de recursos econômicos e de uma coordenação mais eficaz, dificuldade de acesso ao transporte, não-valorização do voluntário. 
Em relação às matérias que dizem respeito ao voluntariado, são fatores de inconstância e descontinuidade das ações: falta de formação específica, não compreensão do contexto penitenciário e dos limites do próprio papel, não consideração das necessidades do interno ou, por outro lado, vitimização do mesmo.

A criação de instrumentos que deem voz à sociedade civil e possibilitem a abertura de um espaço para que as entidades troquem experiências entre si sempre me pareceu fundamental para o crescimento de movimentos político-sociais, e o fortalecimento dos grupos envolvidos. Uma das motivações da presente pesquisa foi possibilitar esse espaço de reflexão e intercâmbio com outras experiências de intervenção de cárcere.

Contudo, ao acompanhar uma das sessões da TPS, e após uma entrevista com Oriol (um padre que realiza trabalhos no cárcere há mais de 20 anos e que já foi membro da TPS), passei a questionar as limitações desse tipo de espaço. Oriol reconhece a boa intenção da ideia, mas segundo ele, a prática da TPS não permite que se instaure um diálogo.

Além das reuniões serem muito teóricas, frias e burocráticas, não cabe à TPS denunciar ou decidir questões de política criminal; tampouco cabe ao grupo ser órgão consultivo, já que o governo, consultor, também a compõe.

\subsection{Administração prisional e entidade da sociedade civil}

Ilustrarei a relação da entidade da sociedade civil com a administração prisional a partir de quatro perspectivas. De início, levantarei algumas hipóteses acerca da expectativa dos Centros Penitenciários em relação à ação do voluntário. Em seguida, delimitarei os caminhos para proposição de atividades no cárcere. Ao final, discutirei os riscos de algumas tendências que se configuram na Catalunha e a ingerência do Centro Penitenciário na seleção dos presos.

\subsubsection{O que querem os Centros Penitenciários?}

Em teoria, a elaboração e proposição de atividades na prisão, podem partir tanto da entidade de voluntariado como do Centro Penitenciário. Porém, ficou evidente nas 
entrevistas com Pablo ${ }^{150}$, Coordenador do Programa per a la Integració dels Presos da FAS, e alguns voluntários que, na prática, a demanda do Centro Penitenciário é determinante na escolha dos tipo de atividade que o voluntário irá realizar.

Ainda que a Lei de Organizació General Penitenciaria preveja no artigo 24 a possibilidade dos presos participarem no planejamento e execução das atividades de execução penal, eles não encontram espaço ou legitimidade para se manifestarem em relação a elas.

Dentre as demandas mais comuns, estão oficinas de artesanato, esportes, atividades culturais, e, cursos para (pretensamente) desenvolver as potencialidades do individuo e o autocontrole, tais como "gerenciamento das emoções" e o desenvolvimento de "habilidades sociais".

Para compreender como essas demandas são materializadas na dinâmica penitenciária, e qual a direção da intervenção proposta, descreverei as atividades realizadas por algumas das entidades analisadas.

Dentre as atividades realizadas pela FAS nos anos de 2010-2011 estão: baile folclórico e sevillanas; oficina de inserção laboral; reforço de matemática, catalão, inglês e castelhano; reiki; oficina de esportes e musculação; oficina de atualidades; oficina de joalheria etc.

No final de 2010, fui gentilmente convidada pelo diretor da Comissão de Prisão da Justícia i Pau, uma das entidades de apoio ao preso mais antigas da Catalunha, para participar da reunião geral com voluntários da prisão. As atividades dos doze voluntários presentes na reunião consistiam em: aulas de teatro, escuta dos problemas dos presos, apoio familiar, comunicação com advogado, denúncias das condições de encarceramento, atividade esportiva, aulas de catalão e matemática etc.

\footnotetext{
${ }^{150}$ Pablo era um jovem catalão de 26 anos, formado em Sociologia pela UB e com experiência em trabalho voluntário, pela Cruz Roja de Mataró, em um centro para população de rua, que, segundo ele, "tem um perfil muito parecido ao dos presos". Quando iniciei o contato com a FAS, em dezembro de 2010, Pablo havia acabado de assumir a coordenação do PIP. Assim, tinha poucas informações, e mostrava-se inseguro para me conceder a entrevista e facilitar o meu acesso aos voluntários. Pablo só autorizou que eu acompanhasse o grupo depois de submeter meu projeto e minha carta de apresentação aos coordenadores da FAS.
} 
Dentro do observado, a demanda mais comum nos Centros relaciona-se ao ensino na penitenciária. Demanda geralmente atendida pelos voluntários, através de aulas preparatórias para o exame de admissão na universidade ou de reforço, principalmente de catalão e castelhano. Com uma população penitenciária composta por $40 \%$ de estrangeiros, é de suma importância o ensino dos dois idiomas oficiais da Catalunha em âmbito penitenciário.

Segundo publicação do OSPDH (2004: 52), os presos não tem motivação para as atividades de tratamento porque, apesar da oferta ser quantitativamente variada, é qualitativamente muito pobre. As propostas de intervenção não supõem um "objeto imediato, tangível e diretamente relacionado aos interesses pessoais do interno". Ademais, algumas atividades, como artesanato (manualidades), cerâmica, basquete e costura de bolas, são muito distantes da vida em liberdade. Nesse sentido, as atividades propostas por voluntários acabam por perpetuar os erros das atividades ditas de tratamento penitenciário.

Segundo o coordenador de projeto da FAS, as oficinas de inserção laboral e habilidades sociais são importantes formas de desenvolver no preso a capacidade argumentativa e crítica. A leitura dessa finalidade deve ser feita a partir do lugar de onde Pablo fala, pois, afinal, o que se compreende por capacidade crítica dos presos?

Se a considerarmos como a negação de alguns aspectos da cultura prisional e da vida no crime, talvez as oficinas contribuam para o desenvolvimento desta capacidade, e, inclusive, da autocrítica. Contudo, se concebermos a crítica como resultado do desenvolvimento da consciência social e política dos presos, certamente tais atividades não contribuiriam com tal desenvolvimento. Ao contrário, esse tipo de atividade tende a responsabilizar exclusivamente o indivíduo preso pelo seu ingresso na prisão, e coloca nas mãos dele suas chances de saída, e a reconstrução de uma vida longe não só do crime, mas da criminalidade, das drogas, das más companhias etc.

Lembro-me de quando acompanhei uma das oficinas de inserção laboral realizada por Andreu, um voluntário da FAS na prisão feminina de Barcelona (Wad Ras). O voluntário, um jovem estudante universitário com uma longa história de participação em projetos sociais (tendo inclusive já trabalhado em uma favela em São Paulo), dava um treinamento 
individual para as presas, que durava cerca de uma hora, para ajudá-las a montar um currículo e se preparar para entrevistas de emprego.

Minha impressão era de que as presas convocadas pelo educador social para participar dessa atividade chegavam na sala sem compreender em que ela consistia, e que, ainda que não estivessem interessadas, acabavam por participar para não frustrar as expectativas do sistema em relação ao seu comprometimento na execução penal. De acordo com Andreu, nos quase dois anos de oficinas, somente uma presa se mostrou agressiva e se recusou a participar, dizendo que tudo aquilo não servia para nada frente às chances reais dela no mercado de trabalho, e sua vontade deliberada de seguir na vida do crime.

\subsubsection{Via de mão única: os caminhos para proposição de atividades no cárcere}

Apesar da previsão de autonomia das entidades para eleição do programa, na prática dificilmente a iniciativa parte da entidade. A proposição de atividade pela entidade de voluntariado requer um caminho longo e burocrático: o voluntário elabora a atividade, remete a proposta para o coordenador da entidade. Este, por sua vez, envia a proposta para a SSPRJJ, e esta a encaminha ao centro penitenciário.

Devido à demora de apreciação por parte de cada uma dessas instâncias, esse processo pode levar mais de um ano, desencorajando a iniciativa das entidades e dos voluntários. Segundo, Marta, voluntária da Fundació Autônoma Solidária, "si tiene una idea y la comenta, es un proceso mucho mas largo".

A demora para inicio das atividades pode comprometer a disponibilidade do voluntário, já que, normalmente, uma pessoa ao se candidatar ao voluntariado (principalmente universitário) tem interesse e disponibilidade para iniciar o trabalho imediatamente, não podendo se comprometer a longo prazo com o projeto.

Logo, visando aproveitar a disponibilidade do voluntário e simplificar o procedimento de ingresso no cárcere, as entidades acabam atribuindo a ele atividades já previamente requeridas pelos centros penitenciários.

Essa tendência de realizar atividades de acordo com a demanda da prisão também pode ser percebida entre os voluntários que já vinham realizando suas atividades a algum tempo. 
Mesmo entre aqueles que as realizam de forma permanente, e que, portanto, poderiam fazer uma proposta para ser executada a longo prazo. Nas entrevistas, quando questionados se gostariam de propor atividades diferentes das que realizavam, muitos respondiam que sim, mas que "era muito difícil e demorado" propor uma atividade; outros me olhavam com surpresa, parecendo que eles nunca haviam pensado na possibilidade de ter uma postura proativa em relação ao sistema.

Com a perpetuidade desse modo de fazer, e amparado na escusa burocrática, o sistema, de forma geral, não acolhe as demandas não-institucionais (da comunidade, dos presos e de suas famílias), nem permite que novas práticas tenham espaço na execução penal.

Logo, apesar de se ter uma abertura do cárcere para a sociedade, o espaço ocupado por ela é limitado e demarcado pela instituição. A prisão aceita a entrada das entidades voluntárias desde que elas realizem uma ação pré-estabelecida pelo sistema, ou, muitas vezes, que os funcionários do próprio sistema deveriam realizar.

O aproveitamento da "mão de obra" voluntária, que é gratuita e geralmente bem qualificada, é uma tendência percebida no campo penitenciário catalão. Como em uma atividade realizada por três estudantes graduandos em Criminologia, voluntários da FAS, que acompanhei no Módulo semiaberto de Brians 1.

Os estudantes acompanhavam os presos numa ida ao complexo esportivo (quadra e academia) para que eles realizassem alguma atividade física. Segundo relato dos presos, eles dependem da presença dos voluntários para realizar qualquer atividade física, pois não há funcionário designado para acompanha-los, e os internos não podem ir sozinhos ao complexo esportivo.

De forma geral, percebi que os voluntários da FAS e Justícia i Pau realizam atividades geralmente demandadas pelo estabelecimento prisional, ou ao menos na linha de outras atividades propostas pelos Centros. Já os dois outros projetos estudados: Abrir la Cárcel e Teatrodentro tentaram romper com a "via de mão única" para a determinação das atividades a serem realizadas. A primeira sem sucesso, já que a proposta de reproduzir um ambiente universitário do projeto Abrir la Cárcel não conseguiu ser levada a cabo, e o grupo foi expulso da prisão de Brians 1 em menos de dois meses. O Teatrodentro, por sua vez, mantém suas atividades a mais de seis anos na prisão de 4 Camins. 
Existem alguns fatores que podem ajudar na compreensão das diferenças entre os dois primeiros grupos citados e os dois últimos. O primeiro fator é que Teatrodentro e Abrir la Cárcel são projetos realizados por um coletivo, que atuam em grupo e dentro de um Centro Penitenciário específico. Seus membros tem afinidade quanto a ideais e objetivos de suas práticas, e, portanto, uma atuação mais organizada e coesa no meio carcerário. Já a $F A S$ e Justícia $i$ Pau, são instituições marcadas pela tradição e por um alto grau de institucionalização, cujos voluntários atuam mais ou menos de forma autônoma e descentralizada (só se encontram nas esparsas reuniões convocadas pela direção das entidades), e realizam uma série de atividades bem distintas entre si.

Além dos mais, Teatrodentro e Abrir la cárcel sustentavam uma posição de enfrentamento em relação às restrições impostas pelo cárcere, e de apurada consciência política do papel que queriam exercer na prisão. Eram grupos que tinham estratégias para garantir uma autonomia relativa no espaço prisional, nem todas exitosas. Já os outros dois grupos aceitavam mais facilmente as determinações e os controles "inerentes” ao cárcere.

\subsubsection{Terceirização da terceirização: gerenciamento privado do voluntariado no cárcere}

Outra tendência percebida na Catalunha é o gerenciamento por instituições privadas da atividade de voluntário no cárcere. A notícia ${ }^{151}$ de um convênio firmado entre o Departament de Justícia da Generalitat da Catalunya com a Oficina de Voluntaris do banco Bilbao Vizcaya Argentaria (BBVA) aponta para a "terceirização da terceirização da execução penal". Ou seja, parte do trabalho que vinha sendo realizado por voluntários sob gerenciamento do Estado, muitas vezes substituindo-o em suas funções básicas, passará a ser intermediado por uma instituição financeira.

Nos termos do convênio, o BBVA colaborará com as atividades de fomento à reabilitação e reinserção sócio-laboral de pessoas submetidas às medidas penais. A oficina de voluntários oferecerá suporte a tarefas relacionadas à educação de internos e internas, bem

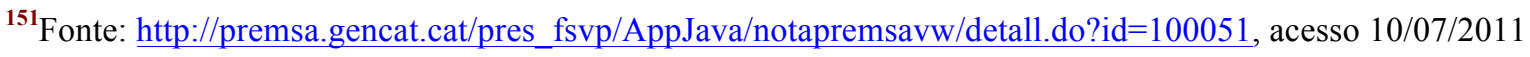


como à sua formação em setores econômicos e laborais como o empreendedorismo e a criação de microempresas.

Em conversa com Antoine, do grupo Teatrodentro, ele apontava esse tipo de transferência como responsável pelo corte ou redução dos convênios existentes entre a Generalitat e entidades autônomas, tal como a dirigida por ele. Em 2011, o projeto de teatro na prisão, começou a ter dificuldades para renovar os convênios e manter a verba destinada à sua realização, enquanto outros grupos com menos força simplesmente não tiveram seus contratos renovados. Segundo Antoine, a Generalitat não estaria mais disposta a patrocinar atividades que poderiam ser realizadas de graça pelos voluntários ou mesmo pelos educadores das prisões.

Além de uma transferência de verbas anteriormente destinadas a entidades da sociedade civil para uma instituição financeira, o teor do convênio aponta para uma valorização de uma perspectiva laboral em detrimento de propostas culturais e artísticas das entidades.

\subsubsection{A ingerência do Centro Penitenciário na seleção dos presos}

Dentro da lógica de "prêmios-castigos e privilégios", participar de uma atividade é tido como um privilégio. Na maioria das vezes, é o centro penitenciário que controla e seleciona os presos que gozarão desse privilégio, com base na sua conduta anterior e durante o cumprimento da pena, e na sua classificação dentro do regime prisional $^{152}$.

\footnotetext{
${ }^{152}$ No sistema penitenciário catalão, os presos são divididos em três regimes de execução penal: fechado, ordinário e aberto (tancat, ordinari e obert), que correspondem respectivamente, aos $1^{\circ}, 2^{\circ}$ e $3^{\circ}$ graus (grados) do cumprimento de pena. Por regra, o interno inicia seu cumprimento de pena em $2^{\circ}$ grado, caso venha a se envolver com "problemas", os quais acarretam as faltas disciplinares (chamados ali partes), ele pode regredir ao $1^{\circ}$ grado. Da mesma forma, a conduta disciplinada do preso, pode lhe conferir a progressão no regime de acordo com a avaliação da Junta de Tratamiento, formada por técnicos da penitenciária (educador, criminólogo) que acompanham a execução da pena do indivíduo.

Conquistar o regime de $3^{\circ}$ grado significa maiores possibilidades de interação com o mundo fora da prisão, principalmente por meio de saídas de fim de semana. Porém, para chegar e permanecer nesse grado, o interno tem que demonstrar comprometimento com o projeto disciplinar; isso na prática exige do preso o seguimento à risca das determinações e controles institucionais, tais como: voltar pontualmente e com sobriedade da saída de fim de semana, estar limpo no exame para detecção de drogas e álcool, não se envolver em brigas, frequentar escola, oficinas ou trabalho, além dos programas especiais oferecidos pelos Centros Penitenciários.

Além da classificação em grados, o preso também é colocado dentro de um "sistema de fases", composto por 4 fases A, B, C e D. Os critérios de determinação da fase são a conduta do interno e sua participação nas atividades de tratamento. Cada atividade, como escola, cursos, oficinas rendem pontos aos presos. Podendo progredir $(\mathrm{A} \rightarrow \mathrm{D})$ ou regredir $(\mathrm{D} \rightarrow \mathrm{A})$ de acordo com seu número de pontos, que atesta seu comprometimento com a disciplina carcerária. O que difere uma fase de outra é a distribuição dos "benefícios penitenciários", tais como o número de visitas (comunicaciones), autorização para passar o dia, fim de semana ou data festiva na rua (permisos de salida), etc.
} 
O poder de classificação do sistema funciona como uma peça importante na economia punitiva-premial. As avaliações dos técnicos do sistema são determinantes na definição qualitativa da medida da pena, já que nesses exames está em produção um saber que classifica o individuo enquanto merecedor de beneficio ou punição, e, portanto, dirige-se à construção de certas subjetividades. O preso, então, vive o dilema entre se mostrar disciplinado e obter alguma liberdade por meio dos "benefícios", ou manter-se indisciplinado e seguir trancafiado.

A avaliação é usada pelo sistema como forma de (des) classificar os presos de atitude inconformista ou contestadora. Presos tidos como "complicados" são punidos com menores possibilidades de acesso ao meio externo.

Dentre as quatro entidades estudadas na Catalunha, somente o Teatrodentro e Abrir la Cárcel conseguiram autonomia na seleção dos participantes. Ambas as entidades demandaram dos Centros que não houvesse qualquer critério para participação dos presos, além da manifestação da vontade de participarem.

Na memória de Abrir la Cárcel o grupo explica a estratégia de divulgação do grupo no interior da prisão:

“Asimismo, se nos permitió que los primeros sábados los dedicásemos a dar unas charlas informativas en el interior de los Módulos de la cárcel con el fin de divulgar el Proyecto entre los presos/as y pedirles, si asi lo deseaban, que se apuntasen a uno u otro Seminario. Durante tres sábados nos dedicamos a esta divulgación en el interior de los cinco Módulos de hombres y del Módulo de Mujeres"

(Abrir la Cárcel,1999: 5)

\subsubsection{A normatização como armadilha à cooptação}

Um marco importante percebido no campo catalão, essencial para a (re) construção da metodologia no estágio de pesquisa e para a compreensão da configuração política local, é que, na Catalunha, a atuação da sociedade civil, assim como de quase tudo que ocorre na prisão, passa (ao menos aparentemente) pela normatização do Estado. 
Desde 1984, a Generalitat de Catalunya tem autonomia em temas de execução penal e vem desenvolvendo mecanismos (eficazes) de governo do território e da população prisional. As dimensões relativamente pequenas ${ }^{153}$ do espaço punitivo contribuem para que ele seja melhor esquadrinhado.

O Departament de Justícia tem controlado mais de uma centena de instituições colaboradoras e voluntárias à quais permite entrar nos Centros Prisionais. Grande parte do que acontece no cárcere está legislado, planificado, regulamentado; e, como consequência dessa dinâmica de cooptação por parte do Estado, os grupos com discursos mais críticos tendem a ficar à margem, alijados de um campo de disputa importante: a própria prisão.

Constatei que, em geral, os grupos com os quais eu tinha mais afinidade teórica encontravam-se fora da disputa do espaço prisional, e os que estavam dentro estavam absorvidos pela maquinaria punitiva. Compartilhei, com ambos, a dificuldade de se criar "linhas de fuga" em um espaço social tão demarcado.

Atualmente, estão em exercício no espaço prisional tecnologias de governo, do outro e de si, que afetam a todos que estão sob seu controle. Esse poder age espelhado em um discurso que combina autoajuda, gerenciamento de riscos e redução de danos, e não está apenas circunscrito na formação do voluntariado, mas permeia uma série de práticas da instituição prisional na contemporaneidade.

É um saber que constrói e atua sobre um individuo fora de contexto, e por estratégias de governo das pessoas e de suas emoções. Esse saber-estratégia atua na produção de uma subjetividade sob controle e "medicamentalizada", apta a gerenciar seus sentimentos, treinada para a submissão, sem possibilidade de revolta.

O voluntário, ao assumir o papel e espaço lhe outorgado pelo cárcere, torna-se uma peça funcional na sua maquinaria. Nessa medida, aproxima-se da figura do "colaboracionista"aquele que tende a auxiliar ou cooperar com o inimigo.

${ }^{153}$ Catalunha conta com 15 Centros Penitenciários e São Paulo 149 Unidades Prisionais. Fontes: http://www20.gencat.cat/portal/site/Justicia e http://www.sap.sp.gov.br/ ， respectivamente, acesso 10/06/2011. 
Para Pau, um padre envolvido com a questão carcerária e coordenador de duas entidades de apoio aos presos (Presos sin fronteras e Associación Expresso), "hacer de mama"154 do preso não ajuda a questionar a necessidade da prisão. Segundo ele, muitos dos voluntários, consciente ou inconscientemente, promovem a prisão ao se constituírem organicamente no sistema.

Durante entrevista com Marta, voluntária da $F A S$, ela questionou por diversas vezes a eficácia da prisão, porém em nenhum momento as normas que regem a dinâmica prisional. Para ela, "Si existe un orden, hay de obedecerlo. La cárcel si no se cumple las ordenes, no funciona"

Foi recorrente no discurso dos voluntários seu posicionamento ao lado dos presos, identificando o sistema penal como inimigo comum. Porém, não havia reflexão da implicação política de suas práticas, nem acerca do quanto sua ação voluntária, benévola, com fins de atenuar o sofrimento e monotonia do cárcere, abafa as possibilidades de resistência.

Com isso, não quero dizer que o fechamento da prisão, ou mesmo o "colaboracionismo", seja uma questão local catalã. Ao contrário, o filtro de quem entra e do que produz na prisão é um mecanismo de defesa fundamental para a continuidade da própria instituição.

Diferentemente do Brasil, fora do estabelecido e autorizado pelo Estado, não se parecem formar linhas de fuga. No campo prisional paulista, a regulamentação do que acontece na prisão se faz a nível local e é compartilhada com os presos (e seus coletivos). O aparato estatal não é eficaz no controle das interações que ocorrem dentro da prisão, nem dela com seu exterior. Daí que se questione o caráter "total" de nossas instituições, onde o dentro e o fora podem ser percebidos mais como continuidade do que como ruptura.

A dimensão e precariedade das instituições, somadas a uma configuração política específica do campo prisional paulista, contribuem para que aqui surjam grietas, agujeros, espaços com (certa) liberdade de ação, que escapam da normatização institucional.

Certamente, no campo prisional paulista, a presença das facções criminosas pautam os limites das interações no cárcere, criando outras formas de aprisionamento. Porém, o

154 "Fazer de mamãe, mimar o preso". 
exercício de poder pelas facções criminosas acaba por afetar mais diretamente os presos e os funcionários do sistema, reequilibrando a relação de força entre dirigentes e dirigidos. Nesse contexto, a sociedade civil figura como um agente externo a esse conflito, posição que pode inclusive favorecer sua entrada no cárcere.

Mariângela Graciano, ao analisar sob o prisma da Educação a presença de instituições civis no cotidiano das unidades do sistema prisional paulista, constata que

"Dada a diversidade de atores e práticas identificadas, é pertinente supor que a intencionalidade também seja variada, mas não existem informações que permitam identificar quais são, como se relacionam entre si nem em que medida constituem ou dão significado à função social da pena"

(Graciano, 2010: 16)

Parece ser justamente a existência de inúmeras fissuras no esquadrinhamento do território carcerário em São Paulo que permite a abertura de caminhos de resistência por grupos que atuam no cárcere, caminhos esses tão difíceis de serem trilhados na Catalunha frente à eficiência de gestão catalã.

\subsection{Motivações e percepções dos presos}

A partir das conversas informais e entrevistas com presos, tentei elaborar algumas categorias que reunissem as diversas motivações declaradas por eles para participarem de atividades com voluntários na prisão, e algumas percepções dessas intervenções.

O substantivo "presos" é empregado nessa análise sem a pretensão generalizante de abranger a diversidade dos internos do sistema prisional, ou mesmo de um centro penitenciário. A formulação dessas categorias obedeceu a um recorte específico do campo e das falas desses interlocutores, e portanto devem ser lidas dentro desse contexto.

A análise dessas motivações serviu para ilustrar algumas percepções dos presos do campo catalão. E contribuiu em especial para que eu revisse o princípio divisório a partir do qual classificava as entidades da sociedade civil. Como explicarei abaixo, um dos pontos que mais me interessavam nos projetos de intervenção no espaço prisional (e que parecia passar desapercebido aos olhos dos presos) era a vontade e a potência de questionar a legitimidade, existência ou necessidade da prisão. 


\subsubsection{As possibilidades e condições de entrevistas com os presos}

Conforme relatado no capítulo anterior, infelizmente (mas de nenhuma forma surpreendentemente), em muitos Centros Prisionais não me foi permitido um momento reservado com os presos, que possibilitasse um ambiente favorável à entrevista.

As conversas com presos que participavam das intervenções da $F A S^{155}$ aconteceram basicamente a partir de contato informal durante a atividade do voluntário. $\mathrm{O}$ mesmo ocorreu ao acompanhar voluntários da Justícia $i \mathrm{Pau}^{156}$. Em ambos os casos, segui inicialmente o caminho formal para conseguir as entrevistas. Porém, em virtude das negativas e dificuldades encontradas, passei a tentar realizá-las informalmente, nem sempre com sucesso.

Utilizarei o substantivo "presos" no masculino, porque ao final não consegui entrevistar nenhuma presa. Na minha única visita à Penitenciária Feminina de Barcelona (Wad Ras), minha tentativa de conversar informalmente com as presas fracassou. Depois de acompanhar o voluntário em uma "oficina de inserção laboral" com uma presa, perguntei se ele se incomodaria de sair da sala para que eu conversasse reservadamente com ela, pedido que ele atendeu; porém, passados dois minutos, uma funcionária entrou energicamente na sala e levou a presa falando que estava na hora do almoço.

Os presos participantes do Teatrodentro foram os únicos com que pude conversar reservadamente, e por diversas vezes ${ }^{157}$. Por meio de uma estratégia informal de entrada, ou seja, sem passar pelo conhecimento do Departament de Justícia, o grupo me permitiu acesso livre e reservado aos presos, de forma que pude aprofundar alguns temas, dos quais trato a seguir.

Além das entrevistas individuais, tive a oportunidade de iniciar e finalizar minha inserção no grupo com duas conversas coletivas, e em roda, com presos e formadores do Teatrodentro no Centro Penitenciário de Quatre Camins ${ }^{158}$.

\footnotetext{
${ }^{155}$ Em abril e maio de 2011.

${ }^{156}$ Em fevereiro de 2011.

${ }^{157}$ Durante as visitas que fiz a penitenciária acompanhando o projeto entre março e junho de 2010.

${ }^{158}$ As atividades do grupo contavam com aproximadamente: vinte presos, dois formadores e um estagiário.
} 
A conversa inicial se deu na minha primeira visita ao cárcere acompanhando o grupo, no espaço do teatro da penitenciária. Nesse dia, seus coordenadores reservaram uma parte do tempo da atividade para que eu apresentasse minha pesquisa e iniciasse um diálogo com participantes do grupo. Depois de uma rápida apresentação da minha trajetória e meus interesses, abri espaço para que os presos me fizessem perguntas; ali era o momento de estabelecer uma relação empática com os participantes e perceber o que interessava a eles me dizer, o que queriam ouvir de mim, e ainda, a compreensão que tinham de mim e de minha pesquisa.

A dinâmica fluiu bem, ainda com a distração causada pelo constante movimento de alguns presos, que se levantavam, iam ao banheiro, saiam para dar uma volta fora do teatro, falavam no canto com outro preso, e, depois, voltavam para roda. Percebi que o que mais interessava aos presos era conhecer o sistema prisional brasileiro ("se nossas cadeias eram como apareciam nos filmes e programas de televisão" ${ }^{\text {159 }}$ ), e ressaltar as qualidades do Brasil, falar de suas praias, mulheres; e até, compartilhar do sonho idílico de se mudar para os trópicos.

Já a roda de despedida ${ }^{160}$ ocorreu nos jardins do teatro da penitenciária de Quatre Camins. Era quase verão, o calor e o cheiro forte no teatro já beiravam o insuportável. Eu havia manifestado a Antoine, diretor do Teatrodentro, o desejo de me encontrar com o grupo, antes de meu regresso ao Brasil, para me despedir e, principalmente, dar um feedback das coisas que observei no campo catalão.

Essa despedida foi um dos momentos mais importantes da minha experiência na Catalunha, pois nesse momento percebi que me sentia parte daquele grupo ${ }^{161}$, e reciprocamente, seus participantes estranhavam minha partida, perguntando surpreendidos se eu nunca mais voltaria a visitá-los. Quase dez meses depois da minha chegada em

\footnotetext{
${ }^{159}$ Uma das conversas mais comuns que tinha nos corredores e intervalos com os presos (e um formadordocumentarista), era se o Brasil correspondia à imagens que eles viam nos filmes e programas de televisão. Certamente, o fato de que, nos últimos anos, as notícias do Brasil tiveram repercussão na mídia internacional, ampliou o interesse e o nível de informação das pessoas acerca do país.

${ }_{160}$ Em julho de 2011.

${ }^{161}$ Desde o início o grupo me incluiu em todos os debates e questões ocorridas durante os encontros em que estava presente. Lembro-me especificamente de um dia, em que o grupo avaliava algumas mudanças no formato do projeto, eu pedi licença para falar, pois não pertencia ao grupo, um preso me deixou a vontade dizendo que eu "já era da família".
} 
Barcelona, percebi que tive com outro grupo uma experiência teórica e prática de reintegração social na Catalunha.

Devido ao riquíssimo material colhido nessas rodas e às condições propícias das entrevistas individuais, os relatos dos presos do Teatrodentro assumem um papel de destaque nesta parte da tese.

Cabe pontuar que nenhum preso do projeto Abrir la Cárcel foi entrevistado, visto que a iniciativa data de dez anos atrás e não foi possível localizar os antigos presos participantes.

\subsubsection{A posição do preso na dinâmica social-prisional e variações na elaboração discursiva}

$\mathrm{Na}$ medida do possível, busquei compreender em que medida a biografia do meu interlocutor, seu "lugar de fala", impactou o discurso por ele proferido. Para tanto, conversei com presos com diversos graus de envolvimento com o projeto e com o cárcere, tentando identificar alguns padrões produzidos por essas variáveis, por meio dos quais construí as hipóteses abaixo.

Durante os encontros que acompanhei junto ao projeto Teatrodentro, percebi que alguns presos assumiam o papel de referência no grupo, tanto em questões relativas a vida carcerária quanto no direcionamento das atividades de teatro. Esses presos costumavam ter falas mais elaboradas, que muitas vezes pareciam expressar os anseios e ideias do coletivo de presos.

Não por acaso, eram presos que acumulavam alguns importantes capitais sociais e simbólicos do campo prisional: eram bem relacionados no cárcere; conheciam bem a dinâmica prisional; tinham conhecimentos jurídicos, principalmente, de execução penal; e às vezes, exerciam uma função ${ }^{162}$ que lhes garantia uma boa posição no jogo prisional. Ademais, os presos que estavam no projeto há mais tempo acumularam experiência em prática teatral, e principalmente, vivências ricas de relação em grupo e com o público das peças anteriores.

\footnotetext{
${ }^{162}$ Alguns deles trabalhavam na cozinha do Centro Penitenciário, enquanto outros exerciam a função de "destino", encarregados de repartir o alimento e encomendas entre os presos, o que corresponderia aproximadamente a função de "faxina" nos cárceres paulistas.
} 
Certamente, os níveis de encarceramento (quantitativo e qualitativo ${ }^{163}$ ) do entrevistado, assim como seu grau de envolvimento com projeto de intervenção da sociedade civil, são variáveis a ser observadas; a medida que afetam a percepção, simbolização, elaboração e verbalização dos presos em relação à presença da sociedade civil no espaço prisional.

De forma geral, os presos envolvidos há mais tempo com os projetos das entidades da sociedade civil ${ }^{164}$ demonstraram mais capacidade de elaboração discursiva e reflexiva dos temas propostos na entrevista.

Atribuo essa diferença ao menos a dois fatores: de um lado, ao processo de apropriação pelos presos dos discursos difundidos pelas entidades e defensores dos direitos humanos; de outro, ao perfil do preso que se envolve em um projeto social porque se sente atraído pela possibilidade de interação social promovida pelo grupo, justamente por encontrar ali um espaço para exercitar sua capacidade de reflexão e de verbalização adquiridas anteriormente e desenvolvidas com o contato com os voluntários.

\subsubsection{Motivações declaradas $x$ motivações esperadas}

Nas conversas com presos participantes dos projetos, um dos pontos que busquei especificamente compreender era se as categorias que criei para pensar o campo encontravam alguma correspondência no discurso dos presos. Com a finalidade de contrapor as motivações declaradas com as motivações que eu esperava encontrar.

Desde a pesquisa exploratória, pensei os projetos da sociedade civil no cárcere a partir do "grau de perturbação" que a entidade causava na dinâmica prisional, e por outro lado, do "nível de absorção" da atividade pela rotina carcerária. Duas variáveis difíceis de serem auferidas, mas que me guiaram na construção do campo, na medida em que identificava os projetos como mais próximos de uma postura colaboracionista (alto nível de absorção e baixo grau de perturbação) ou de atitude crítica (baixo nível de absorção e alto grau de perturbação).

\footnotetext{
${ }^{163}$ Quantitativo em relação aos anos de cumprimento de pena de prisão, e qualitativo em relação à forma de cumprimento: conquista de direito a visitas, benefícios, progressão de regime etc.

${ }^{164}$ Essa percepção se aplica tanto ao campo catalão, quanto ao campo paulista.
} 
No decorrer da pesquisa de campo, constatei que meus critérios de definição das entidades não faziam sentido aos olhos de meus interlocutores. De modo geral, questões ligadas à problemática da absorção e perturbação não ressoavam na fala dos presos, tampouco nas dos voluntários. Porém, elas apareceram nos discursos de alguns atores específicos, que problematizavam o papel a ser ocupado no cárcere.

Em especial, compartilhei muito dos questionamentos dos formadores ${ }^{165} \mathrm{e}$ demais profissionais do Teatrodentro. A tal ponto que, em uma das últimas sessões que acompanhei do grupo, uma psicóloga responsável pelas supervisões do projeto indagou aos presos qual a percepção deles sobre diferentes projetos desenvolvidos no cárcere, justamente um dos temas que me interessava explorar. Ela perguntou se eles viam diferença entre fazer teatro, e participar de outras atividades no cárcere, tal como cerâmica, já que ambas atividades eram alternativas ao pátio e formas de ocupar o tempo (duas das mais comuns motivações apontadas pelos presos para participar do projeto de teatro). As respostas a tal indagação foram vagas, a maioria não apontou o projeto de teatro como uma atividade que se diferencia das demais, a meu ver, principalmente por sua dimensão política.

Quando perguntados acerca das atividades em âmbito de voluntariado que conheciam ou tinha participado, os presos não fizeram distinções substantivas acerca delas. Ao contrário, alguns elementos foram comuns às avaliações de participantes dos mais diversos projetos. Nesse sentido, os presos destacaram como as principais contribuições da sociedade civil o respeito e a forma amistosa do voluntário se relacionar com o preso.

Já o contraste existente entre as atividades realizadas por funcionários da prisão e pela sociedade civil apareceu bem demarcado no discurso dos presos. Ao serem perguntados acerca do envolvimento da sociedade civil no cárcere, quase a totalidade deles valorizou o fato do voluntário ir a cárcere sem qualquer contraprestação pecuniária, independente da atividade que realizavam.

Aos olhos dos presos, a atenção, o cuidado e a presença terna que pressupõem a ação voluntária parecem mais importantes do que a forma e conteúdo que a atividade irá

\footnotetext{
${ }^{165}$ Técnicos contratados pelo Teatrodentro, para dar formação de luz, som, interpretação, etc.
} 
assumir.

A partir dessa leitura, posso afirmar que as motivações declaradas pelos presos estão mais associadas à possibilidade de interação social viabilizada pela intervenção do que à potência política da ação contra o cárcere.

\subsubsection{Motivações primárias e secundárias}

A partir das observações do campo, poderia sustentar a hipótese de que as motivações para os presos participarem dos projetos sofrem modificações de acordo com a familiarização das atividades ali propostas ${ }^{166}$. Na maioria dos casos, as motivações que atraíram o indivíduo para conhecer o projeto, chamadas aqui motivações primárias, dão lugar a outra série de motivações responsáveis pela permanência e aderência do indivíduo à proposta, denominadas motivações secundárias.

Foi comum aos presos recém incorporados ao projeto, e mesmo aos com mais experiência, expressarem motivações ligadas à negação e ao esquecimento da sua condição de preso, tais como "fuga do pátio", quebra da monotonia e entretenimento.

Além dessas motivações primárias centradas na recusa da prisão, para alguns presos a escolha por participar da intervenção apareceu ligada à possibilidade de construção de um espaço alternativo à dinâmica prisional. Estas motivações secundárias parecem ser de caráter mais afirmativo. Nesse sentido, o espaço compartilhado com a sociedade civil foram representados como um lugar onde pudessem "respirar alguma liberdade", ou que lhes servisse de canal de expressão e ventilação de suas ideias.

Proponho que o desenvolvimento desse segundo grau de motivação seja lido a partir da atitude crítica ${ }^{167}$ de Foucault, como um desejo de resistência, no sentido de reinventar as possibilidades de interação na prisão vida e resistir às atuais formas de sujeição

Este segundo tipo de motivação foi mais comum nos presos com mais tempo e maior grau de envolvimento com propostas de intervenção social, e em alguns presos com um capital cultural $^{168}$ anterior ao contato com projeto.

\footnotetext{
${ }^{166}$ Processo parecido com que passam os voluntários que vão ao cárcere, conforme exporei em seguida.

${ }^{167}$ Conceitos apresentados no Capítulo 3.
} 
Percebi ainda que o discurso e as práticas institucionais da entidade da sociedade civil influenciavam as categorias e o tipo de fala de seus participantes, sejam voluntários ou presos. A motivação dos participantes variou conforme o nível de profundidade das reflexões propostas pelos projetos.

Com o processo de maturação, e através do aprofundamento das reflexões sobre o grupo e a consciência de seu papel dentro dele, as motivações primárias, de forma geral mais explícitas e verbalizáveis, dão lugar às motivações secundárias. De acordo com a hipótese em construção de Alvino Augusto de Sá ${ }^{169}$, poder-se-ia afirmar que esse caminho iria da fuga e negação para a busca e conquista em uma "linha evolutiva motivacional".

\subsubsection{Pensando em categorias}

Ao ouvir os presos, percebi motivações comuns nos mais diversos contextos, inclusive encontrando várias aproximações nos campos paulista e catalão. Ainda que inseridos em projetos de diferentes naturezas, e em estabelecimentos prisionais com características bem distintas, as representações dos presos guardavam muita proximidade entre si.

A partir delas, criei seis categorias que reúnem algumas das motivações expressas pelos presos para participarem do projeto. São elas: "Fugir e negar a prisão"; "Quitar el pateo”; Beneficiar-se"; "Sentirse a gusto"; "Respirar alguma liberdade", "Expressar-se: o grupo como um canal".

Tentei ordenar a apresentação das motivações, partindo das mais "populares" (compartilhadas por presos envolvidos nos mais diversos projetos) em direção às mais específicas, mencionadas com menos frequência pelos entrevistados. Pude constatar que as motivações mais frequentes estavam associadas à negação ou fuga da prisão; somente em alguns discursos a intervenção da sociedade civil apareceu como um espaço produtivo de uma alternativa à dinâmica prisional.

\footnotetext{
${ }^{168}$ Aqui incluo presos com alguma leitura em ciências sociais, seja por formação auto-ditada ou universitária. Alguns, inclusive com trajetória política em movimentos sociais na rua, considerados por muitos os "novos presos políticos" da Catalunha.

${ }^{169}$ Compartilhada em comunicação pessoal em dezembro de 2011.
} 
A partir desta observação, proponho a hipótese de que as motivações primárias (ligadas à fuga e negação da prisão) são compartilhadas pela grande maioria de presos que se envolvem em um projeto de intervenção no cárcere, enquanto as motivações secundárias aparecem com menor frequência, e podem estar associadas ao grau e tempo de envolvimento do preso com o projeto, e à capacidade de abstração e elaboração discursiva do mesmo.

A organização em categorias contribuiu para sistematizar a análise do discurso dos presos. Essa divisão foi realizada sem a pretensão de que abrangessem a totalidade e as nuances das diversidade de fala dos presos, tampouco de formular uma hipótese quantitativaestatística.

As categorias são apresentadas a título ilustrativo, de tal sorte que elas não se excluem entre si, ou seja, um mesmo entrevistado pode ter declarado mais do que um tipo de motivação. Ademais, algumas das frases destacadas abaixo contém duas ou mais motivações; nesses casos, destaquei o aspecto condizente à categoria em análise.

\section{Fugir e negar a prisão}

Diversas motivações declaradas pelos presos para participarem das atividades propostas pelos voluntários estavam ligadas à ideia de fugir da realidade da sua condição de encarcerado.

Foi comum ouvir dos presos que a atividade ajudava a "matar o tempo da prisão", "manter-se com a cabeça ocupada", "llenar el día". Um dos presos do Teatrodentro associou sua experiência no grupo como: "una evasión de la condena que tienes" "170.

Frente à monotonia da rotina carcerária, é comum os presos se interessarem por qualquer atividade diferente, que impacte o cotidiano prisional. Tal como descreve Molina (1997:186) no contexto de um de seus projetos de intervenção:“los presos que pasaban todo el día sin hacer nada en el patio, estaban deseosos de hacer cualquier cosa que les sacase del aburrimiento y del hastio".

\footnotetext{
170 "Uma fuga da pena que se tem".
} 
O preso, de antemão, tem interesse por qualquer atividade que "faça vivo o tempo morto da prisão". Nesse sentido, a fuga do dia-a-dia prisional pode ser lida como a motivação primária mais comum dos presos para se envolverem com uma atividade de voluntariado.

\section{$>$ “Quitar el pateo": fugindo das tentações e confusões}

Algumas falas dos participantes do Teatrodentro, tais como: "Cuando llegas aquí es mas libre" ou "yo vengo aquí para volar un poco, despejarme la mente" ${ }^{171}$, apontam para uma percepção cindida do espaço prisional, entre o "aqui" (teatro) e o "lá" (demais espaços da prisão). Sendo o "aqui” representado como um lugar mais livre que "lá".

Nas representações da prisão, o pátio ocupa o lugar, por excelência, da cultura prisional. As interações sociais entre os presos ocorrem sem intermédio dos funcionários do sistema, e portanto, sua dinâmica obedece mais aos ditames dos dirigidos do que dos dirigentes. Lugar onde se arruma briga, droga, e toda sorte de confusões e esquemas, denominadas trapicheos $^{172}$ nas prisões catalãs.

Como na fala de presos envolvidos na atividade de esportes promovida pela $F A S$ : "yo iba a para quitar el murmullo del pateo. Salir de la monotonía del pateo”. No mesmo sentido, manifestam-se outros do Teatrodentro: "Vengo al teatro para quitar el pateo de encima. Malas cosas pasan en el pateo: drogas, peleas, trapicheos"; ou mesmo "Estoy enganchado al teatro ${ }^{173}$, me divierto, me paso bien. He dejado el del pateo, del funcionario. Cuando menos me vean, mejor".

Um das estratégias da reintegração social é introduzir no cárcere atividades alternativas ao pátio, na sua forma mais ampla e diversa. Molina (1997: 207) fala em ocupar o tempo de uma maneira positiva, em atividades que interessassem aos presos e lhes servisse de algo, e que contribuíssem para "ampliar o mundo do preso" ao criar motivações novas, a nível lúdico, laboral e educacional.

\footnotetext{
171 "Clarear a mente"

172 Trapichear: Ingeniarse, buscar medios, no siempre lícitos, para lograr algún fin. Fonte: http://www.wordreference.com/definicion/trapichear, acesso 03/11/2011.

${ }^{173}$ Interessante notar que a expressão "estar enganchado a", normalmente se refere à adição à substâncias entorpecentes.
} 
Ocupar o tempo do preso é uma estratégia central para a disciplina e o controle do mesmo, e poderia ser representada pela máxima "cabeça vazia é oficina do diabo". Muitas das atividades planejadas pela prisão perseguem o objetivo implícito de afastar o preso do pátio e manter a disciplina prisional, em detrimento do objetivo explícito, de "tratamento penitenciário".

O problema é quando a intervenção no cárcere é absorvida pela lógica institucional de prêmio-castigo. Nesse sentido, a ação da sociedade civil inscreve-se no registros das atividades recomendadas pela prisão. A participação nessas atividades condiciona a concessão dos "benefícios penitenciários”, conforme analisarei em seguida.

\section{Beneficiar-se: cumprir com o papel que esperam dele}

O preso pode alcançar alguns benefícios por estar inserido em atividades oferecidas pela prisão. Entre elas, atividades com voluntários. Na Catalunha, algumas atividades rendem "pontos" ao preso. O acúmulo destes pontos ajudará o preso quando este vier a pleitear algum beneficio penitenciário, tais como autorização de saídas (los permisos) e mudança de regime (grado). Aos olhos da Junta de Tratamiento, a participação nessas atividades demonstra que o preso está seguindo o caminho que a administração prisional traçou para sua reabilitação.

Apesar de ser um tema fundamental na vida dos presos, poucos se referiram explicitamente a essa motivação. Ocultar esse interesse é uma estratégia para conquistar prêmios no jogo penitenciário. Afinal, para a administração prisional não basta que eles compareçam às atividades, é preciso também convencer que sua adesão ao plano de tratamento é sincera, e não utilitária.

Porém, como não há muita chance fora desse jogo, os presos dependem desses pontos, e valorizam as atividades por isso. Antoine, diretor do Teatrodentro, contou que de início, o grupo era contrário ao sistema de pontos, porque não queria participar da mecânica institucional. Porém, devido à pressão dos presos, que não pontuavam enquanto estavam nas atividades de teatro, voltaram atrás e aderiram parcialmente ao sistema ${ }^{174}$.

\footnotetext{
${ }^{174}$ Cabe pontuar que atividade de teatro não garante muitos pontos ao preso, em comparação a outras como a frequência à escola.
} 
O GDUCC, no ano de 2010, enfrentou um dilema parecido ${ }^{175}$. O juiz das execuções penais resolveu conceder remissão de pena aos presos participantes do grupo, decisão que os coordenadores do grupo receberam com receio pelo risco de instrumentalização do grupo.

Por outro lado, os mesmos coordenadores buscaram a oficialização do grupo como um projeto de extensão da Faculdade de Direito da USP, o que reverteria créditos aos alunos participantes. Apesar dessa última medida também trazer o risco do utilitarismo, desta vez por parte dos alunos, esse receio não apareceu nos debates que acompanharam o processo de reconhecimento da atividade, dos quais eu participei.

\section{"Sentirse a gusto" 176}

Diversos presos relacionaram o bem-estar sentido com a quebra da rotina ocasionada pelos voluntários, cuja presença promove formas diferentes de interação dentro da monotonia da prisão, e até alguns lapsos de liberdade.

Um preso definiu o Teatrodentro como "un sitio que te sientes más a gusto”, manifestando que "fica mais à vontade" realizando as atividades trazidas pela sociedade civil do que em outros espaços da prisão.

Um outro preso, em aula de reforço de catalão promovida pela Justícia i Pau na Cárcel Modelo, usou mais uma vez a expressão: "en ese espacio te sientes a gusto. Conoces la gente y establece una relación amistosa".

Essa motivação parece ir além de uma fuga da tensão das relações no pátio e com os funcionários. Ela aponta para uma vontade de não apenas negar o pátio, mas para a perspectiva de participar de outro tipo de interação, onde o preso "sinta-se à vontade".

A relação com as pessoas da sociedade civil requer que o preso mobilize outro vocabulário e outros temas, estranhos ao cotidiano prisional. E permite que seus participantes entrem em contato, expressem e questionem sua forma de estar no mundo e sua relação com o outro, com o desvio e com a punição.

\section{$>$ Respirar alguma liberdade}

\footnotetext{
${ }^{175}$ Voltarei a falar especificamente do grupo no Capítulo 8.

176 "Sentir-se a vontade".
} 
"Esquecer por alguns momentos que estavam presos" foi uma das ideias que ouvi de diversos presos acerca da motivação para participar das atividades propostas pela sociedade civil.

Se tal atividade consegue envolver os participantes a ponto de se sobrepor, ainda que momentaneamente, à realidade da prisão, parece-me que algum êxito se alcançou em matéria de reintegração social.

A proposta da reintegração social é que as pessoas envolvidas descubram, encontrem ou redescubram parte de sua subjetividade. De forma que, tanto os presos em contato com a sociedade livre como os representantes da sociedade civil em contato com o cárcere, questionem suas propostas de vida frente ao convívio social.

Nas avaliações finais de diversas edições do GDUCC que participei, foi comum ouvir dos presos a ideia de que no grupo eles "respiravam alguma liberdade". Esse feedback sempre me pareceu importante para um trabalho que pretende reduzir o isolamento do preso. Ao mesmo tempo, eu via com desconfiança a afirmação da potência libertadora da intervenção, questionando-me se a realidade totalizante da prisão permitia alguma fuga (ainda que simbólica e momentânea) desse espaço.

Pude refinar a minha compreensão dessa questão a partir de uma experiência pessoal de reintegração social na prisão, que se aproximou do sentido verbalizado pelos presos como “esquecer por um momento que estavam em uma prisão". Essa aproximação deve ser lida levando-se em conta todas as ressalvas advindas da diferença do lugar que ocupo em relação àquele em que está o preso.

Em março de 2011, fui acompanhar as atividades do Teatrodentro no Centro Penitenciário de Quatre Camins. Como era o primeiro dia que estava com o grupo, decidi realizar as atividades juntamente com os participantes, como forma de me inserir no grupo e ganhar certa intimidade com meus informantes.

Tratava-se de um exercício de improvisação teatral. Eu estava em um grupo com 5 presos, e teríamos que montar uma pequena peça (uma esquete em linguagem teatral) para 
apresentar ao final da tarde. Eu entrei no jogo, dei algumas ideias para nosso roteiro e atuei no palco do teatro da penitenciária.

Envolvi-me tanto com a atividade que, quando me dei conta, havia realmente esquecido que estávamos no espaço de uma prisão, e assim pude compreender um pouco melhor, a partir de uma vivência pessoal, o que os presos queriam dizer sobre esse "respirar liberdade".

\section{Expressar-se: o grupo como um canal}

Outra motivação, ainda que menos recorrentemente citada, era que o espaço de interação com pessoas da sociedade civil proporcionava a abertura de um canal de expressão para os presos.

Os presos participantes do Teatrodentro destacaram a forma como eram tratados pelos membros do grupo. "El tracto es distinto aquí en el teatro. Es un tracto mas cercano, con respecto", que lhes possibilitava um ambiente de confiança para que expressassem suas ideias e emoções.

Mas, além disso, o espaço do teatro apareceu associado à liberdade: "Es una libertad hacer teatro, pude decir lo que quiere, reír. Es mucha libertad...", ou, ainda, como um lugar de resistência: "Soy un poco anti-social, en el grupo puedo hablar de cosas que no hablo en el pateo”. Essa última observação parece reunir ao mesmo tempo uma motivação de fuga (do pátio constrangedor), associada a uma motivação de busca (de um lugar para expressão de suas ideias e vivências).

De acordo com a hipótese levantada anteriormente, a sobreposição da segunda motivação sobre a primeira dependerá da conjunção de diversos fatores, tais como: a capacidade de abstração e elaboração do indivíduo; o tempo e nível de participação no projeto; os objetivos do preso e do projeto de intervenção social, e a profundidade das reflexões e discussões produzidas nesse encontro.

\subsection{O papel do voluntário por ele mesmo}

$\mathrm{Na}$ fala dos voluntários acerca do impacto que suas ações causavam no cárcere, percebi que algumas concepções, expressões e metáforas estavam presentes em diversos discursos. 
A partir das entrevistas realizadas por mim com voluntários na Catalunha e das publicadas pelo Departament de Justícia $(2011)^{177}$, selecionei algumas categorias recorrentes no discurso do voluntário penitenciário para justificar sua atuação no cárcere. São elas: curiosidade e morbo; satisfação pessoal; levar "ar fresco" para dentro do cárcere; dar visibilidade à questão prisional; e contribuir para a melhora do sistema prisional.

As falas dos entrevistados em catalão foram traduzidas livremente para o português. As expressões em castelhano, de mais fácil compreensão, foram mantidas, na tentativa de preservar as expressões tal como ditas pelos entrevistados.

Da mesma forma que as motivações dos presos para participar dos projetos da sociedade civil, as representações dos voluntários acerca de seu papel na prisão tendem a se transformar de acordo com seu envolvimento com o projeto e sua capacidade discursiva. A motivação inicial que atrai o voluntário para a atividade normalmente é sucedida por uma motivação secundária, mais elaborada, que mantém o participante conectado à atividade.

De forma geral, o voluntário é movido incialmente por uma curiosidade sobre o cárcere e sobre os presos. Com o tempo de envolvimento no projeto e o contato com as práticas e reflexões que envolvem a intervenção social no cárcere, motivações mais elaboradas são introduzidas no discurso dos voluntários, tais como dar visibilidade à questão prisional e questionar a pena de prisão.

\section{- Curiosidade e o morbo}

Apesar de nem sempre mencionada explicitamente na fala do voluntariado, a vontade de conhecer aquele espaço inacessível para a maioria da população aparece como uma das motivações centrais dos voluntários, principalmente os de perfil universitário.

\footnotetext{
${ }^{177}$ O Departament de Justicía entrevistou 3 voluntárias: Montse da l'Obra Social Santa Llü̈sa Marillac que faz acompanhamento educativo em uma prisão da Catalunha, Cati da Cedre- Associació per a la Promoció Social que prisão dinâmicas de grupo, além de saídas programadas com os presos e Estrella l'Associació Som-hi, que faz uma oficina de artesanato na penitenciária feminina de Barcelona.
} 
Em uma reunião que presenciei do Grupo $33^{178}$, percebi a decepção dos "pretendentes ao voluntariado" quando a coordenadora falou que o objetivo principal do grupo não era realizar trabalho dentro das prisões, mas uma ação política fora. Os presentes, em sua maioria, estudantes universitários de Criminologia, ficaram desapontados com a notícia, já que viam no grupo a chance de ver na prática o que ouviam na faculdade. Segundo uma das voluntárias-universitárias presente, existiam duas maneiras para entrar na prisão: na condição de técnico ou estagiário penitenciário, ou como voluntário.

Muitos voluntários universitários se engajavam no voluntariado para ter uma experiência antes de decidir se queriam trabalhar no cárcere ou não. Era o caso de Marta, voluntária da FAS e estudante de psicologia, que teve seu primeiro contato com a prisão a partir das aulas de reforço de catalão que dá na penitenciária feminina de Wad Ras. Já a voluntária Julia, da Associació Som-hi, falou sobre a curiosidade de saber o que havia levado uma pessoa a prisão.

Alguns entrevistados também apontaram a curiosidade, que denominaram morbo, como motivação de outros voluntários (que não eles mesmos) realizarem seu trabalho. Apenas uma voluntária reconheceu que seu interesse na prisão foi motivado pelo morbo.

Interessante interpretar essa resposta tendo em conta o sentido da palavra $m o r b o^{179} \mathrm{em}$ castelhano. Tal palavra não corresponde diretamente à palavra em português mórbido, já que, na língua espanhola, ainda que seu uso esteja relacionado a uma tendência para o desagradável, guarda também um sentido de excitação, inclusive sexual.

\section{- Satisfação pessoal}

Alguns entrevistados assumiram expressamente uma satisfação pessoal em ajudar o outro. Em, outros, eu percebia um "orgulho em fazer o bem gratuitamente", ainda que abafado pela humildade que se exige do caridoso.

\footnotetext{
${ }^{178}$ Uma plataforma integrada por diversas pessoas da sociedade civil catalã, sob o lema "otro derecho penal es posible". O grupo busca a ampliação para Catalunha e toda Espanha do modelo terapêutico da Unidad Terapéutica y Educativa (UTE) de Vilabona: http://www.utevillabona.es/, acesso 02/02/2011.

179 Tendencia obsesiva hacia lo desagradable, lo cruel, lo prohibido. Fonte: http://www.wordreference.com/definicion/morbo, acesso 3/11/2011.
} 
Estrella, voluntária da Associació Som-hi, reconhece o ganho pessoal com o voluntariado: “é certo que uma parte de generosidade, mas por outra parte é por própria satisfação... Pode parecer egoísta, mas há uma parte pessoal que faz sentir bem. Dar alguma coisa a alguém que necessita naquele momento"

O coordenador de prisão da Justícia i Pau, lembra que o voluntário sente-se bem fazendo seu trabalho, e ainda pode contar para os amigos. Trata-se de uma experiência de aprendizagem humana, na qual algumas vezes o voluntário leva mais do que deixou.

\section{- Levar "ar fresco" para dentro do cárcere}

Outra percepção recorrente foi a de que o voluntário levava "ar fresco" para a prisão, fazendo com que o preso se esqueça por alguns momentos de sua condição de encarcerado. A ideia de "ar fresco" aparece ligada ao fato do voluntário criar uma atmosfera agradável durante a interação na prisão, de forma que os presos e presas "podem passar bem o tempo, se distrair, rir um pouco", conforme a fala de uma voluntária aposentada da Justícia i Pau.

Estrella, voluntária da Associació Som-hi que trabalha há quatro anos em uma penitenciária feminina oferecendo oficinas de artesanato, diz que as presas "valoran el aire fresco que los voluntarios aportan”. A mesma metáfora foi usada por Montse, uma voluntária que realiza acompanhamento educativo pela entidade Obra Social Santa Llü̈sa Marillac: "os voluntários levam ar fresco e oferecem aos outros a oportunidade de se expressarem livremente, e de aproveitar de um tempo e espaço aonde podem ser pessoa, dar-se e sentirse observado de uma forma diferente da qual são vistos na prisão. Eles podem se expressar e remover preocupações e sofrimentos".

Cati, jovem voluntária do Cedre, aponta uma tendência da entidade, que nos últimos anos tem optado por levar à prisão atividades mais lúdicas, de distração, para que passem bem o tempo, e menos de reflexão. Apesar da voluntária reconhecer que através do jogo pode-se levar aos presos uma outra maneira de pensar.

Uma prisão é um espaço de tensão e desconfiança. Daí a importância de se propiciarem momentos leves na interação prisional. A ação lúdica pode contribuir para que o preso perceba e sinta, ao menos por momentos, o quanto ele está sendo reprimido pelo sistema e o quanto ele poderia viver melhor. 
Porém, se não acompanhada de uma reflexão, essa ação se traduz em mero entretenimento, uma distração para que o preso se afaste de sua condição de ator histórico-político. Nesse sentido, a ação do voluntário acaba por contribuir com o bom andamento do sistema, e não com o processo de reintegração social, conforme analisarei mais adiante.

\section{- Dar visibilidade à questão prisional}

"En efecto la falta de conocimiento sobre los centros cerrados y el imaginario colectivo que genera, crea prejuicios y estereotipos desde la sociedad civil. La visión equivocada de la realidad (por ambas parte) impide procesos de comunicación entre personas privadas de libertad y la sociedad civil".

$$
\text { (Louvat }{ }^{180} \text {, diretor do Teatrodentro) }
$$

O cárcere é uma instituição opaca. Apesar de se tratar de um instituição pública, a sociedade pouco conhece da realidade penitenciária. A opinião pública tece uma rede de representações acerca da prisão e dos presos sem ter contato com o real funcionamento do sistema carcerário.

Combater as imagens estereotipadas, falsas, que tem como referência o "cinema norteamericano", foi um dos motivos atribuídos para a entrada de pessoas da sociedade civil na prisão. Seja na ótica delas próprias, seja na ótica dos preso.

Marta, da FAS, falou sobre a importância de "hacer visible la problemática de la cárcel, enseñar que por detrás de la cárcel existen personas". Segundo ela, "no se habla de la cárcel de una forma humana, cuando se habla es para decir que están llenas, con inmigrantes".

Um dos presos do Teatrodentro fala da importância de pessoas da sociedade entrarem nos Centros Prisionais para assistirem seu espetáculo: “o que entra é por curiosidade, depois logo veem que somos pessoas normais"

\section{- Contribuir para a melhora do sistema prisional}

\footnotetext{
${ }^{180}$ No texto Teatro en cárceles, s.d.: 2, Disponível no site: www.redlece.org/biblioteca/Louvat.pdf, acesso 25 de novembro de 2010.
} 
Cati é uma jovem voluntária da Cedre - Associació per a la Promoció Social, que realiza dinâmicas de grupo na prisão, além de saídas programadas com os presos de tercero grado. Apesar da Cedre não ter entrado como uma das entidades da amostra, entrevistei Cati no início da minha pesquisa, pois, ao contatar algumas entidades de voluntário, recebi a resposta dessa jovem disposta a me ajudar. Ela mesma tinha curiosidade pela criminologia e pelos debates em torno da prisão.

Ela foi um dos únicos voluntários que esboçou uma crítica contundente em relação ao tratamento dado ao preso e às expectativas em relação à prisão. Segundo ela, "para reabilitar ou reinserir, deveria ser feito um trabalho muito mais forte do que trancá-los na prisão".

Percebi que a intenção dos voluntários não é fazer com que a prisão se torne menos necessária, mas sim reavivar o sonho de uma prisão melhor. Dessa forma, o impacto do voluntariado na sociedade é no sentido de reafirmar a legitimidade da prisão, e não de questionar a sua existência ou necessidade. Nesse sentido, serve como exemplo a fala de Estrella, da Associació Som-hi, para quem "a sociedade deveria chegar a crer que a prisão reabilita porque muita gente não crê. Deveria ser demonstrado que as pessoas que saem não voltam a delinquir. Viria bem que houvesse uma visão mais ampla desse tema".

Ademais, grande parte dos voluntários, ao serem questionados sobre o impacto do voluntariado penitenciário na sociedade, falaram sobre a mudança na imagem do preso e da prisão. Eles acreditam no potencial da ação voluntária para convencer a sociedade de que o preso é alguém passível de reabilitação, um "não-monstro", e que a prisão, se melhorada, pode ser o motor dessa mudança.

Ainda que esses discursos insistam na relegitimação da instituição prisional, em ao menos dois aspectos eles podem ser vistos como um avanço em matéria de reintegração social. Primeiro, porque partem do pressuposto de "presunção da normalidade do preso", concebendo-o como alguém com plenas condições de se inserir num convívio social. Depois, porque incitam a sociedade a se implicar com a questão prisional. $\mathrm{O}$ interesse da sociedade em ter uma "visão mais ampla" do que ocorre na prisão já seria um avanço em matéria de execução penal. 


\subsection{O preso pelos olhos do voluntário : algumas representações}

Outro tema interessante que surgiu nas entrevistas foi a construção da figura do preso. De modo geral, os voluntários que conheci tinham um olhar compreensivo e nutriam certa compaixão por aquele a quem dedicava seu trabalho. No espectro de concepções acerca do criminoso que compõem o imaginário social, a percepção do voluntário se aproxima mais da figura do criminoso-vítima do que do criminoso-algoz.

A figura do preso foi geralmente percebida pelos voluntários no contexto de suas histórias de vida. Foi comum na fala dos voluntários o reconhecimento da condição de "vulnerabilidade" psíquica e social do preso. Duas construções foram predominantes: o preso como alguém doente e incapaz (principalmente no caso dos dependentes químicos); e o preso vulnerável socialmente, que teve uma vida dura, com poucas oportunidades, proveniente de uma família desestruturada, em sua maioria de origem pobre e migrante.

Em contrapartida, o perfil do voluntariado é bem diferente. Compõe-se basicamente de pessoas de classe média, em sua maioria estudantes universitários ou aposentados, com uma vida relativamente regrada. A distância social que separa o voluntário do preso se reflete na distribuição desigual do capital social (na terminologia de Bourdieu) entre esses dois grupos, e na ação do voluntário compartilhar um pouco de seu capital com aquele que sofre e sofreu tantas privações.

Talvez, uma das motivações implícitas no trabalho voluntário, mas que se evidencia nas relações e discursos acerca dos presos, é realizar uma "mea-culpa social". Retribuir de alguma forma o conhecimento e tempo de que dispõem por conta de sua posição privilegiada na sociedade.

Nesse sentido, é interessante demarcar que aquele que realiza o voluntariado na prisão tem, ou passa a ter, uma representação do preso distinta do restante do corpo social. Essa diferença pode ser compreendida a partir de ao menos dois fatores: o primeiro é o fato de que as pessoas que se dispõem a realizar alguma atividade não-remunerada na prisão tem, de início, alguma compaixão pelo preso, e uma preocupação com a forma da execução da pena privativa de liberdade, o que já o diferencia da ignorância e inércia da maioria da população no tocante à execução penal. E depois, o fato dos voluntários manterem contato 
periódico com o preso possibilita que a figura do preso se torne mais factível, e que o voluntário reconheça o humano atrás do criminoso.

Pablo, coordenador de projetos no âmbito da Justiça da $F A S$, para quem "a prisão propriamente dita não é um meio de reinserção", acredita no potencial do voluntário para mudar a consciência do preso e o imaginário social da prisão. Ele observa uma mudança no discurso do voluntário, que geralmente inicia seu trabalho com uma visão positiva da reinserção social, e com o tempo, passa a adotar uma postura mais crítica em relação à instituição penal e positiva em relação aos internos.

Porém, na tentativa de afirmar para si e para outrem a humanidade do preso, o voluntário corre o risco de romantizar a figura do interno, engessando-o no papel de vítima ou do pecador arrependido, sem refletir sobre as condições sociais e históricas que perpassam a escolha individual, nem sobre a relação conflituosa do preso com a sociedade e com o sistema de controle.

Tanto entre os voluntários da Catalunha como entre os de São Paulo, foi comum a percepção do preso como alguém que errou e quer se redimir. Nesse sentido, o ato criminoso é percebido como um desvio na história do individuo, e a ação do voluntário é direcionada para apoiar o preso que quer fazer novas escolhas, andar por caminhos aceitos socialmente.

Se, por um lado, é recorrente no discurso dos voluntários a construção positiva da figura do preso, por outro, prevalece a crença de que o preso vai tentar se aproveitar da pessoa que circula entre o mundo da prisão e o de fora para obtenção de favores.

Essa dubiedade aparece no discurso de Montse, da Obra Social Santa Llü̈sa Marillac: "no cárcere, tem muitas pessoas com problema mentais ou psicológicos derivados de sua situação pessoal, da desestruturação familiar etc., que podem te manipular".

No mesmo sentido é a fala de Cati, da Cedre: "na prisão tem que se manter uma certa distância, não ser fria, porque tem de ser acolhedora com eles... Suponho simplesmente que são garotos que estão na prisão, mas não se há de implicar -se extremamente com as suas histórias". Para ela, implicar-se extremamente poderia trazer confusões. Os presos 
estão muito necessitados, e querem usar o voluntário para que faça alguma coisa fora, de má fé ou não: Tem que ser sincero com você mesmo e marcar os limites. Não pode salvar todo mundo".

O governo da Catalunha, conforme relatei anteriormente, nutre a preocupação de pautar os limites da ação do voluntário. E tenta, durante o Curso "Intervenció en centres penitenciaris des del voluntariat”, alertá-los acerca do perigo de atender aos pedidos dos presos.

O sentimento de desconfiança nas relações estabelecidas no cárcere e o perigo de ser ludibriado apareceram não somente nas falas dos voluntários, mas também na percepção de alguns presos. Em uma conversa com presos de Quatre Camins, participantes do Teatrodentro, eles me relataram que "na prisão não se tem amigos, todos querem tirar alguma vantagem". Principalmente no pátio, cujas relações de interesse refletem-se na economia de troca de café, cigarros, drogas e outros bens valorados pelos presos.

\subsection{Dentro ou fora do jogo: uma tipologia das estratégias de resistência}

Foucault (2004), em “A filosofia analítica da política”, propõe uma tipologia das formas de resistência. Segundo o autor, existem as resistências individuais e as coletivas, assim como existem as resistências no interior do jogo de poder, e as resistências que recusam o próprio jogo.

Das quatro entidades que compuseram meu campo na Catalunha, somente duas tinham práticas e discursos que questionavam a prisão, e que ao meu ver, compunham verdadeiras estratégias de resistência coletiva. Eram elas o Teatrodentro e o Abrir la Cárcel.

Ambas confrontavam o poder institucional, e lutavam ao lado dos presos por um ambiente prisional menos disciplinado, criando com eles alguns mecanismos de resistência ao controle institucional. Porém, isso foi feito a partir de duas estratégias distintas. De acordo com a tipologia proposta por Foucault, uma delas resistiu dentro do jogo de poder, e a outra recusou o jogo, quando mudou suas regras.

\subsubsection{Recusa de Abrir la Cárcel}


Estavam programadas para os anos de 1999-2000 uma série de seminários coordenados pelos professores da Universitat de Barcelona e outros centros, com mais de 200 presos oficialmente inscritos para assisti-los. (OSPDH, 2004: 316). A proposta inicial do grupo era que o projeto fosse desenvolvido em duas prisões catalãs: no Centre Penitenciari de Brians e no Centre Penitenciari d'Homes de Barcelona, "La Modelo". Porém, a Direcció General de Serveis Penitenciaris i de Rehabilitació del Departament de Justícia requereu ao grupo que limitasse seu trabalho a Brians $I$, requisição à qual o grupo atendeu.

O projeto pretendia uma oferta educativa/formativa desvinculada do sistema punitivo premial, com criação de verdadeiras possibilidades de reinserção social (OSPDH 2004: 308, 309) A metodologia de ação do grupo consistia em reproduzir o espaço de aula na prisão. Pata tanto, o grupo colocou algumas condições: que as turmas de alunos fossem mistas (compostas tanto por presos quanto por presas); que não houvesse qualquer restrição quanto aos presos que participariam do seminário (libre asistencia); e que os seminários transcorressem sem a presença de funcionários da penitenciária.

Apesar de serem basicamente "só" essas as condições para a realização do projeto, elas confrontam diretamente algumas das regras estruturantes da vida prisional: a limitação na interação com pessoas de outro sexo e a vigilância constante da instituição, justificada pela necessidade ilimitada de segurança, e portanto de controle das dinâmicas que acontecem naquele espaço.

De acordo com a memória do Projeto (Abrir la Cárcel, 1999:5), na sua fase de implementação, em setembro de 1999, houve uma reunião para acertar a sua execução, na qual estavam presentes os proponentes, o diretor de Brians e "todos los mandos de la cárcel". Ficou acordado que as atividades se desenvolveriam nos fins de semana, para não afetar as atividades diárias já programadas

Os seminários tiveram seu início no dia 13/11/1999, sem qualquer tipo de incidente. No segundo dia de atividades (20/11/1999), o funcionário encarregado de conduzir os presos até a classe quis tirar da lista dos participantes do Seminário um preso que queria voltar ao Módulo aonde ficava sua cela. Depois dos responsáveis pelo Abrir la Cárcel explicarem ao educador que a decisão de excluir participantes não era de sua competência, além de funcionar como uma sanção encoberta ao recluso, o funcionário respondeu: "entonces, 
vuestra actividad no vale nada, se trata de un vis-a-vis encubierto" e se foi. O grupo fez, então um relatório escrito do ocorrido e apresentou ante o diretor do Centro.

No dia seguinte, domingo 21/11/1999, uma das apresentadoras do Seminário de Música (Profesora del Departamento de Filosofía del Derecho de la $U A B$ ) foi à prisão com outras quatro pessoas. Ali as esperavam o Jefe de Servicios que, junto a outros funcionários da prisão, comunicou ao grupo que acompanhariam as aulas, mesmo cientes de que sua presença não estava autorizada pela administração penitenciária. A professora deu inicio à atividade, mas ante a tensão do ambiente, decidiu por suspendê-la em seguida.

No sábado seguinte, o grupo da universidade foi ao Centro de Brians como previsto. Nesse dia ocorreu um incidente distinto. Ao que parece, um preso e uma presa que estavam discutindo saíram pela janela, e foram imediatamente detidos por funcionários. Tal acontecimento motivou o educador (o mesmo presente no incidente na semana anterior) a tirar da classe uma das senhoras que realizavam a atividade, exigindo sua identificação, chegando a quebrar o pase que ela levava preso a roupa. Ao fim da atividade com os grupos, os membros de Abrir lá Cárcel foram conduzidos ao escritório do subdiretor da prisão, que os interrogou sobre o sucedido e lhes pediu um relato escrito sobre o ocorrido.

Desde o início, os funcionários da penitenciária mostraram-se contra o projeto. Em uma demonstração de que não queriam compartilhar o gerenciamento da prisão, acusavam os acadêmicos de "não conhecer os presos" como eles conheciam.

Eles denominavam o projeto "vis-a-vis universitário", em uma clara alusão de que os encontros consistiam num privilégio para os presos, já que o "vis-a-vis" é um direito (extremamente limitado) dos presos de se comunicarem com suas visitas. Logo, os encontros dos presos com os acadêmicos era visto pelos funcionários como uma extensão disfarçada e ilegítima desse direito.

Em dezembro de 1999, os funcionários demonstravam expresso desacordo com a presença do grupo no centro prisional: 
"en las últimas semanas hemos recibido diversas llamadas del Director del Centro Penitenciario de Brians en las cuales nos ha expresado siempre la total oposición del colectivo de Funcionarios de la cárcel a que este Proyecto continúe"

(Abrir la Cárcel, 1999: 7)

Por meio de seus sindicatos (CC.OO., UGT y CATAC), os funcionários penitenciários, solicitaram por escrito que não se autorizasse mais a entrada dos membros do projeto, e que no futuro não se permitisse mais a realização desse tipo de Programa "sino tan sólo de aquéllos que sean fiscalizados y controlados directamente por la cárcel" (Abrir la Cárcel, 1999:7).

É importante identificar as categorias mobilizadas nos discursos dos funcionários. Eles apontaram para a ilegalidade do projeto, porque os obrigava a deixar as funções para as quais eles tinham sido designados, ainda que a atividade tivesse sido autorizada por seus superiores hierárquicos. E acusavam os membros do grupo de usarem da atividade como meio de favorecer seus trabalhos como advogados, além de promover o já citado "vis a vis universitário".

Essas finalidades não-declaradas foram atribuídas ao projeto como forma de desqualificálo perante a administração prisional, e reforçar o mantra segundo o qual a segurança é a necessidade primeira e essencial na prisão, e a entrada de pessoas de fora só atrapalha os funcionários no cumprimento de sua tarefa de contenção. As acusações dirigidas ao projeto apontam para a deslegitimidade das atividades, que queriam preservar certa autonomia no cárcere e se afastar do controle direto da instituição prisional.

A oposição dos sindicatos ao projeto na prisão de Brians I fez com que a Direção Geral de Serviços Penitenciários cedesse e não mais permitisse a entrada de docentes no centro, dando fim prematuro ao projeto, no início do ano 2000.

No ano de 2001, alunos e professores da Universitat de Barcelona (UB), vários dos quais remanescentes do "Abrir la Cárcel", fundam o Observatori del Sistema Penal i els Drets Humans com o objetivo de investigar as instituições do sistema penal e contribuir com a defesa e promoção dos Direitos Humanos (OSDPH, 2008:11). 
Em 2004, o OSPDH publica um informe denunciando as condições das prisões na Catalunha. As denúncias foram recebidas como um ataque ao sistema prisional, ao ponto de alunos e professores do OSPDH se tornarem persona non grata nas prisões da Catalunha.

Tal configuração, e principalmente o desfecho dessa história, apontam para a forma de distribuição da economia de poder no campo prisional: a instituição controla as possibilidades de interação que ocorrem nesse espaço.

A simples recusa dessa forma de distribuição de poder, através do enfrentamento direto da administração prisional, só pode ter como consequência a expulsão da entidade do jogo prisional e o fim de qualquer projeto reintegrador.

\section{* Avaliação da estratégia do grupo frente à proposta da reintegração social}

A relação com o pessoal penitenciário é uma das peças chaves para a meta de reintegração social. Para que a atividade proposta pela sociedade civil tenha aderência e continuidade no espaço prisional, é necessário o apoio mínimo dos funcionários penitenciários, principalmente dos agentes penitenciários, que ficam na linha de frente da execução penal.

Pela perspectiva da reintegração social, recomenda-se ao estranho que quer desenvolver um projeto no cárcere manter um diálogo aberto não só com os presos, mas com os funcionários do sistema. Pelos olhos destes últimos, a atividade da sociedade civil pode ser vista como uma ameaça ao "monopólio do modo de fazer prisional". E, nesse conflito entre entidade da sociedade civil e prisão, certamente a prisão sairá vencedora, e a entidade expulsa do cárcere.

Analisando a trajetória do "Abrir la Cárcel", pode-se afirmar que o embate direto entre academia e penitenciária foi o que ocasionou o fim prematuro do projeto. Ainda que o grupo tenha negociado sua entrada na prisão, reunindo-se com diretor e funcionários até chegarem ao consenso para a realização do projeto, parece-me que não manteve o diálogo aberto que assegurasse não só sua entrada, mas sua permanência no espaço prisional.

Academia e cárcere são duas instituições históricas, com seus respectivos vícios históricos, e cuja interação poderia ser encarada mais como uma troca de experiências e de saberes do 
que como disputa pelo poder. Se há alguém que tem a responsabilidade por tomar iniciativa nesse sentido, é a academia, a quem cabe o papel de liderança na reflexão sobre a prática.

A estratégia de resistência adotada pelo "Abrir la Cárcel", e logo pelo OSPDH, parece ser a recusa do jogo. Em entrevista ${ }^{181}$ com o criminólogo Iñaki Rivera Beiras, coordenador do "Abrir la Cárcel" e fundador do OSPDH, o sucesso de uma ação crítica, que não legitime a existência da prisão, depende da articulação com canais de apoio externo. $\mathrm{O}$ desenvolvimento de canais de comunicação funcionaria como uma caixa de ressonância do que acontece entre os muros, especialmente a partir de redes sociais formadas por grupos que atuam no cárcere.

Porém, além da articulação entre as entidades e o exterior, seria necessário um contexto político favorável, que suportasse esses novos modos de fazer prisional. Ainda segundo Iñaki, a Catalunha está longe de ter um contexto favorável. Pelo contrário, para ele, na atualidade não há qualquer abertura política para grupos que questionam a prisão. "É quase impossível pensar em realizar um trabalho que questione os rumos do emprisionamento na Catalunha".

\subsubsection{Teatrodentro}

O projeto Teatrodentro é desenvolvido desde 2005 no Centro Penitenciário de Quatre Camins. A proposta do grupo consiste em realizar atividades no marco da educação não formal na prisão, com o objetivo de promover um processo educativo individualizado.

Dentro desse marco, as atividades de teatro ${ }^{182}$, fotografia, e mais recentemente vídeo, não se limitam a mais uma “oficina artística-ocupacional”, mas pretendem ir além da ocupação

\footnotetext{
${ }^{181}$ Realizada em junho de 2011.

182 TRANSformas centra-se na metodologia criada pelo brasileiro Augusto Boal, que estabelece duas premissas sobre as quais constrói todo seu ideário: em primeiro lugar, reduzir a distância entre o povo e a cultura; em segundo lugar, provar que o teatro pode ser praticado por qualquer pessoa, em qualquer lugar. No teatro do oprimido, a audiência incorpora-se ativamente como parte da ação dramática, e portanto, toma o controle dela e pode modificá-la. A teoria boaliana se baseia na utilidade do teatro como ensaio da ação social, que estimula o individuo a refletir sobre o passado, transformar a realidade presente e inventar um futuro. Este teatro não só apresenta uma visão do mundo, mas questiona com propostas concretas a opressão, experimentando diferentes opções de resposta. Estas são ensaiadas, com a finalidade de empregar-las em processos futuros de troca/mudança comunitária, que repercutirão no crescimento pessoal do individuo como ator social. Fonte http://www.trans-formas.com/pag_teatrodentro.asp, acesso 11/10/2011.
} 
e do ócio, consolidando-se como um instrumento educativo complementar à educação formal e "que tiene muy en cuenta el complejo recorrido que el preso ha de realizar en su paso del interior (prisión) al exterior (sociedad civil)" (Louvat ${ }^{183}$, s.d.: 2)

Tomei conhecimento do trabalho desenvolvido pela TRANSformas alguns anos atrás, quando ainda redigia o projeto da presente investigação doutoral. Lembro que agrupei algumas informações desta e de outras duas instituições europeias (parceiras no Teatrodentro) e coloquei-as como um possível campo internacional da minha pesquisa, o que naquele momento não passava de um sonho muito distante.

Um mês após minha chegada na Espanha, recebi o convite para o festival INOUT Festival Europeo de Creaciones Artísticas realizadas en prisión, a ser realizado na Catalunha em novembro de 2010, cuja programação, além de mesas redondas e projeções, contava com entrada do público em centros penitenciários para acompanhar um espetáculo teatral ou à projeção de um filme.

Estive presente na grande maioria das atividades do festival realizadas em Barcelona. Foi meu primeiro contato direto com uma entidade da Catalunha. A partir dela, aproximei-me de grupos da sociedade civil que desenvolviam trabalhos em centros prisionais, e pela primeira vez pude entrar em uma prisão europeia.

Apesar de adotar estratégias distintas das de outros grupos ditos mais radicais, os coordenadores de Teatrodentro reconhecem a importância e o impacto político-social que esses grupos podem causar. Citam como exemplo o impacto que o "grupo do Iñaki" (OSPDH) causou no âmbito penitenciário em 2004, a ponto de Antoine (diretor do Teatrodentro) atribuir a relativa melhora nas condições prisionais, principalmente no tocante a maus tratos, torturas e outros tipos de abusos, à ação do OSPDH.

Ainda que reconheçam como legítima (e por vezes necessária) a ação de enfrentamento de grupos como o OSPDH, os coordenadores do projeto Teatrodentro parecem adotar outra estratégia, menos radical, que lhes garante permanecer no jogo que o sistema prisional lhes

${ }^{183}$ No texto Teatro en cárceles, s.d.: 2 . 
propõe. Como aponta Joan, um dos formadores do projeto: "Tenemos colegas que fueran echados porque no querían jugar el juego. Nosotros lo jugamos”.

Essa estratégia ficou evidente durante os dias em que acompanhei o grupo no cárcere. Foi também explicitada em entrevista com seus coordenadores, que falaram que "não tinham poder para fazer um ataque frontal ao sistema", e que a negociação do poder prisional era como um "esporte de combate" - uma alusão à sociologia de Bourdieu e um sinal da percepção do campo prisional como um campo de luta.

Trata-se de um projeto político mas sem bandeiras, pautado na luta contra o sistema penitenciário. A estratégia do grupo consiste em estar dentro do espaço prisional, e desde ali, abri-lo para pessoas de fora e propiciar a circulação de presos a outros espaços. As atividades são pautadas pela criação artística, sem perder de vista o contexto político-social dos atores.

Ocupar e se manter nessa posição delicada no campo prisional exige uma série de estratégias que garantam o sucesso do projeto. Certamente, ao conciliar as expectativas institucionais com as do próprio grupo, alguns posicionamentos estratégicos e trunfos do Teatrodentro possibilitaram sua permanência no jogo, tais como: visibilidade das ações, inserção em redes de apoio, trabalho horizontal, apelo social, qualidade artística, bom relacionamento com os funcionários do cárcere, confiança dos presos.

Uma das preocupações da Associação TRANSformas, que executa o projeto Teatrodentro é a visibilidade de suas ações: "todas las actividades se insertan en una comunidad. Para evitar el peligro de que sean endogámicas impulsamos cambios en sus propios contextos. Dependiendo del ritmo, identidad y competencias de cada grupo, éste se involucra en lo que ocurre a su alrededor participando, sugiriendo, reflexionando teatralmente..."

O trabalho horizontal é outra das estratégias do grupo, de forma que cada um fale desde sua experiência, rompendo com a verticalidade das relações prisionais: "En una prisión, donde todo se mueve por lideres, intentamos trabajar la horizontalidad para contrarrestar lo que viven" 184

\footnotetext{
${ }^{184}$ La dificil relación entre presos y sociedad civil, http://www.elperiodico.com/es/noticias/cultura-y-espectaculos/20101110/teatro-entrebarrotes/586109.shtml, acesso 11/10/2011.
} 
Nas sessões em que acompanhei o grupo na penitenciária de Quatre Camins, percebi que os formadores do Teatrodentro brincavam e puxavam papo com diversos funcionários da penitenciária que cruzávamos no caminho até o teatro. Mais tarde, soube por Antoine que toda aquela amistosidade fazia parte de uma estratégia para criar simpatia e familiaridade entre os funcionários e o grupo.

Nesse sentido, pode-se afirmar que a entidade adotou uma estratégia oposta do "Abrir la cárcel". Ao incluir os agentes penitenciários na interação com a sociedade civil, o grupo pôde promover também um redimensionamento do lugar do cárcere na subjetividade do funcionário, que, tal como os presos, também está submetido ao processo de prisionização.

De forma geral, o trabalho realizado para os presos desperta certo ressentimento nos funcionários do cárcere, também carentes social e emocionalmente, e que veem a sociedade civil se mobilizando para atender "àqueles que erraram", enquanto eles mesmos seguem incompreendidos e sozinhos.

Dar atenção ao pessoal penitenciário é uma das estratégias para sobreviver dentro do sistema. Baratta (1990) já nos alertava quanto a esse cuidado, que guiou nossa atuação frente ao GDUCC, conforme relatarei adiante.

Entretanto, além de boa relação com pessoal penitenciário, é essencial que uma ação dirigida aos presos seja bem recebida pelos próprios destinatários. Para Joan, do Teatrodentro, conquistar a confiança do preso é difícil, principalmente porque "la cárcel exige que el preso mienta", e paira no ar o medo de que estejam sendo alvo de análise, julgamento, experimentos. Para romper um pouco com a reprodução do papel institucional representado pelo preso, assim que começa um trabalho Joan já adverte: "no somos educadores, no queremos buenos alumnos".

O apoio e envolvimento com os presos é outro dos pilares do Teatrodentro. Conquistar a confiança dos internos é condição para o sucesso de qualquer trabalho desenvolvido no cárcere. Em entrevistas com presos participantes do projeto, estes elogiaram a forma aberta como são apresentadas e resolvidas as questões do grupo, e o respeito dos formadores para com eles, que um dos presos resumiu com a seguinte frase: "Ellos están a favor de nosotros, eso es lo importante”. 
O grupo parece ter consciência do lugar que lhe atribuem na dinâmica prisional, que é o de funcionar no processo de reabilitação como ferramenta terapêutica. Conforme atesta Joan em entrevista com formadores do projeto:

"Hay gente que se refiere a nosotros como terapia. Ese de ninguna forma es nuestro objetivo. Ahora, puede ser que la creación teatral tiene una consecuencia terapéutica, de conocer a si mismo".

O autoconhecimento é o que possibilita que a verdade de si emerja em direção à construção de uma subjetividade livre, não aprisionada. Logo, a criação de um espaço para o exercício da liberdade e da individualidade dentro da prisão é certamente uma forma de resistência. Identifiquei, na ação do grupo, um poder que devolve a fala aos presos, e que se exerce no seio da prisão.

Dentre as diversas entidades que conheci durante o estágio doutoral na Catalunha, certamente o projeto Teatrodentro foi o que mais se aproximou do que eu idealizava como um projeto de reintegração social, ao mesmo tempo contra e dentro da prisão.

Molina (1997: 162) propõe uma paradoxal "colaboração critica" com a instituição prisional, colaborando no desenvolvimento de projetos comuns de intervenção, mas críticos quanto às suas imposições. Esse parece o caminho escolhido pelo projeto Teatrodentro.

O projeto resiste há seis anos no interior do jogo de poder. As sessões são realizadas no teatro sem a presença de qualquer funcionário da prisão. Para se manter tanto tempo atuante no espaço da prisão, preservando alguma autonomia, sem ser absorvido ou expurgado pela instituição prisional, é preciso saber jogar. E entrar no jogo não significa necessariamente submissão:

"Hay que ir con cuidado. Se nos dice a menudo esto es reformismo. Pero, de hecho, el reformismo se define por la manera cómo se obtiene lo que se quiere o lo que se busca conseguir. A partir del momento en que se impone por la fuerza, por la lucha, por la lucha colectiva, por el enfrentamiento político, no es una reforma, es una victoria”"

(Foucault, 2008: 85) 
PARTE III

EXPERIÊNCIAS DE REINTEGRAÇÃO SOCIAL

NAS PRISÕES PAULISTAS

\section{CAPÍTULO 7}

\section{EXPERIÊNCIAS DE REINTEGRAÇÃO SOCIAL NO ESTADO DE SÃO PAULO}

Nesta terceira e última parte da tese, detenho-me em algumas experiências de reintegração social no campo paulista. O universo empírico de investigação no Estado de São Paulo desenvolvidos pela sociedade civil no período de realização desta pesquisa, ou seja, de janeiro de 2009 até dezembro de 2011.

Dentro destes marcos, selecionei experiências que estivessem sob a responsabilidade da sociedade civil (em parceria ou não com o Estado) consideradas inovadoras no sentido de reaproximar a sociedade civil do cárcere, e vice-versa, de acordo com os critérios detalhados no Capítulo 4.

Retratarei, no presente capítulo, quatro dessas experiências: Projeto “Quem somos nós?”, "Curso transdisciplinar de criminologia penitenciária e execução penal", "Leiturativa" e "TV Cela".

Inicio o capítulo expondo o desenvolvimento e limites da pesquisa no campo paulista. Em seguida, caracterizo as experiências selecionadas, a partir de um roteiro comum de apresentação dos projetos, e proponho algumas breves reflexões acerca das intervenções.

\subsection{Desenvolvimento e limites da pesquisa no campo paulista}

No decorrer da presente pesquisa, busquei privilegiar a percepção das pessoas envolvidas e afetadas pelos projetos da sociedade civil no cárcere, de forma que o discurso oficial das entidades pudesse ser lido à luz das práticas colocadas em jogo por seus atores. 
Porém, especificamente na análise dos grupos que compõem o campo paulista (apresentados neste capítulo), tive de optar por uma abordagem mais institucional, em detrimento de uma perspectiva pessoal dos membros da sociedade civil e presos envolvidos com o projeto. Focar na perspectiva institucional foi a saída encontrada frente à dificuldade de realizar um trabalho de campo com o mínimo de amplitude e regularidade no campo paulista.

Apesar de ter conversado pessoalmente com três ${ }^{185}$ coordenadores das quatro entidades que compõem o campo, não tive possibilidade de acompanhar a execução dos projetos na penitenciária ${ }^{186}$, tampouco de entrevistar presos participantes ou outros membros da sociedade civil envolvidos nos projetos. Atribuo esse déficit a dois motivos principais: primeiro ao prazo limitado de três anos para conclusão do doutorado, dos quais um terço foi dedicado ao estágio sanduíche; e depois, às reconfigurações por que passaram os projetos no decorrer da pesquisa.

O prazo de três anos para a conclusão do doutorado limitou as possibilidades de realização de uma pesquisa de campo mais extensa e de uma análise mais profunda. Infelizmente, por conta do limite de tempo, não pude investir tanto nas entrevistas e relatos etnográficos dos grupos paulistas, tal como o fiz com os grupos catalães, ou mesmo em relação ao GDUCC, objeto do próximo capítulo.

O primeiro ano do doutorado (2009) foi destinado ao cumprimento dos 40 créditos exigidos, à pesquisa bibliográfica e à pesquisa exploratória. O período do estágio sanduíche, compreendido entre setembro de 2010 e junho de 2011, abriu outro campo de pesquisa, mas me afastou por quase um ano do contato com as entidades em São Paulo. Logo, tive que concentrar a coleta de dados de campo paulista em um único semestre (primeiro semestre de 2010), concomitantemente à elaboração do texto de qualificação.

No segundo semestre de 2011, além de finalizar a redação da tese, ainda vi necessidade de seguir com a pesquisa empírica. Porém, priorizei acompanhar as atividades do GDUCC e

\footnotetext{
${ }^{185}$ Presidenta do IACC e executores dos projetos "Leiturativa" e "Quem somos nós?".

${ }^{186}$ Com exceção do projeto "Leiturativa", em 29/07/2010 pude participei de uma "roda de leitura" promovida pelo projeto na Penitenciária Feminina do Butantã.
} 
entrevistar alguns de seus atuais participantes, de forma a atualizar os dados e o andamento do grupo.

Uma das características comuns às ações promovidas pelo terceiro setor é a instabilidade. A continuidade de um projeto é condicionada às conjunturas políticas de cada época e a renovação de parcerias e convênios. Nos onze meses em que fiquei afastada do Brasil para realização do estágio sanduíche, muitas coisas mudaram no campo paulista. Nesse ínterim, alguns dos projetos que eu acompanhava terminaram, outros cresceram, e novas propostas de intervenção surgiram nos cárceres de São Paulo.

Realizei a seleção dos projetos que comporiam o campo paulista no final do ano de 2009, dando preferência aos projetos que estavam em andamento na época. Porém, no desenrolar da pesquisa, um dos projetos (“Quem somos nós?”), que esperava renovação do convênio, não a obteve; e uma das entidades (IACC) não realizou nenhum projeto nos últimos dois anos.

O projeto "Leiturativa", ao contrário, teve outra sorte nos anos de 2010 e 2011 . No final de 2010, o grupo foi selecionado pelo programa Fomento e Difusão de Produção Cultural do Governo do Estado, promovido pela Secretaria Estadual de Cultura, e expandiu em 2011 as atividades do projeto a mais de vinte unidades prisionais no Estado de São Paulo.

O “TV Cela", iniciado em 2009 na Cadeia Pública Feminina de Votorantim, parece ter sido o projeto que se manteve mais estável no decorrer desses três últimos anos, nos quais parece ter crescido, ampliando o reconhecimento e a repercussão de suas atividades. Porém, como explicarei adiante, o próprio "TV Cela" originou-se a partir de um projeto anterior de seus realizadores: "Povo Marcado", um programa de rádio produzido nos anos de 2007 e 2008 na mesma unidade prisional.

Devido às contingências narradas acima, não pude reunir os dados do campo que desejava e tampouco construir uma rica análise dos grupos. Logo, o que proponho no presente capítulo, é a apresentação de um "banco de casos" construído a partir de material documental e informações prestadas pelos coordenadores dos projetos; um retrato de quatro diferentes propostas contemporâneas de reintegração social nos cárceres paulistas. 


\subsection{Quadro-resumo das experiências selecionadas}

No quadro abaixo sintetizo os projetos que compuseram o campo paulista da tese.

\begin{tabular}{|c|c|c|c|c|c|}
\hline $\begin{array}{l}\text { Nome do } \\
\text { projeto }\end{array}$ & $\begin{array}{l}\text { Entidade } \\
\text { Promotora }\end{array}$ & Resumo da proposta & $\begin{array}{l}\text { Unidade } \\
\text { prisional }\end{array}$ & $\begin{array}{c}\text { Perío } \\
\text { do }\end{array}$ & $\begin{array}{l}\text { Fonte de } \\
\text { pesquisa }\end{array}$ \\
\hline $\begin{array}{l}\text { “Quem } \\
\text { somos } \\
\text { nós? }\end{array}$ & $\begin{array}{c}\text { ITTC- } \\
\text { Instituto Terra } \\
\text { Trabalho e } \\
\text { Cidadania }\end{array}$ & $\begin{array}{l}\text { Através de oficinas temáticas, } \\
\text { busca incentivar reflexões junto } \\
\text { às mulheres que estão presas, } \\
\text { especificamente em relação à } \\
\text { temática de violência, cidadania } \\
\text { e questões de gênero. }\end{array}$ & $\begin{array}{l}\text { Penitenciár } \\
\text { ia } \\
\text { Feminina } \\
\text { da Capital } \\
\text { e de } \\
\text { Santana }\end{array}$ & $\begin{array}{c}2008 \\
- \\
2009\end{array}$ & $\begin{array}{c}\text { oficina de } \\
\text { formação na } \\
\text { metodologia } \\
\text { de trabalho do } \\
\text { grupo }+ \\
\text { conversas } \\
\text { informais com } \\
\text { as executoras } \\
\text { do projeto }\end{array}$ \\
\hline $\begin{array}{l}\text { "Curso } \\
\text { trans- } \\
\text { disciplina } \\
\text { r de } \\
\text { crimi- } \\
\text { nologia } \\
\text { peniten- } \\
\text { ciária e } \\
\text { execução } \\
\text { penal" }\end{array}$ & $\begin{array}{c}\text { IACC- } \\
\text { Instituto de } \\
\text { Ação Contra- } \\
\text { Cena }\end{array}$ & $\begin{array}{l}\text { O Curso propõe aos alunos um } \\
\text { espaço de discussão e reflexão da } \\
\text { dinâmica criminal e do processo } \\
\text { de reintegração social. Ele tem } \\
\text { início com conhecimentos } \\
\text { teóricos gerais de criminologia, } \\
\text { que preparam o aluno para a } \\
\text { intervenção no cárcere (parte } \\
\text { prática do Curso) }\end{array}$ & $\begin{array}{c}\text { Penitenciár } \\
\text { ia } \\
\text { Feminina } \\
\text { de Santana }\end{array}$ & $\begin{array}{c}2007 \\
- \\
2009\end{array}$ & $\begin{array}{l}\text { entrevista com } \\
\quad \text { dois } \\
\text { coordenadores } \\
\text { + análise } \\
\text { documental } \\
\text { (relatos dos } \\
\text { participantes) }\end{array}$ \\
\hline $\begin{array}{c}\text { Projeto } \\
\text { Leiturativ } \\
\text { a }\end{array}$ & $\begin{array}{l}\text { FESPSP- } \\
\text { Fundação } \\
\text { Escola de } \\
\text { Sociologia e } \\
\text { Política de } \\
\text { São Paulo }\end{array}$ & $\begin{array}{l}\text { Propõe ciclos de leitura e debates } \\
\text { em penitenciárias paulistas, a } \\
\text { partir de livros, revistas, jornais, } \\
\text { matérias de televisão e rádio, } \\
\text { filmes e documentários, palestras } \\
\text { de vários segmentos }\end{array}$ & $\begin{array}{c}\text { Diversas } \\
\text { Penitenciár } \\
\text { ias da } \\
\text { Capital }\end{array}$ & $\begin{array}{l}2004 \\
- \\
\text { atual } \\
\text { men } \\
\text { te }\end{array}$ & $\begin{array}{c}\text { relato } \\
\text { etnográfico de } \\
\text { um encontro } \\
\text { + conversas } \\
\text { informais com } \\
\text { presas e } \\
\text { coordenador } \\
\text { do projeto }+ \\
\text { blog na } \\
\text { internet }\end{array}$ \\
\hline $\begin{array}{l}\text { "TV } \\
\text { Cela" }\end{array}$ & $\begin{array}{l}\text { Associação } \\
\text { Cultural } \\
\text { Votorantim }\end{array}$ & $\begin{array}{l}\text { Programas de rádio e de televisão } \\
\text { realizados pelas presas, com a } \\
\text { ajuda de profissionais da área de } \\
\text { comunicação voluntários. Os } \\
\text { programas são transmitidos em } \\
\text { uma rádio local e em canais } \\
\text { comunitários. }\end{array}$ & $\begin{array}{c}\text { Cadeia } \\
\text { Pública } \\
\text { Feminina } \\
\text { de } \\
\text { Votorantim }\end{array}$ & $\begin{array}{l}2009 \\
- \\
\text { atual } \\
\text { men } \\
\text { te }\end{array}$ & $\begin{array}{c}\text { filme- } \\
\text { documentário } \\
+ \\
\text { vídeos dos } \\
\text { programas }\end{array}$ \\
\hline
\end{tabular}




\subsection{Roteiro de Apresentação dos Projetos}

Como forma de dar sistematicidade à apresentação dos projetos de reintegração social, seguirei um roteiro inspirado no proposto pela Escola de Administração Penitenciária do Estado de São Paulo ${ }^{187}$, o qual foi adaptado de acordo com as especificidades e informações reunidas acerca de cada projeto

I. Apresentação

a) Título do projeto

b) Realizadores, idealizadores, parcerias e convênios

c) Estabelecimento(s) prisional (is) onde se realiza

II. Objetivos

III. Público alvo, seleção dos participantes e número de pessoas envolvidas

IV. Metodologia

V. Histórico e duração do projeto

VI. Inserção no campo prisional

VII. Relação com o pessoal penitenciário

VIII. Principais dificuldades

IX. Reflexos do trabalho e avaliação

X. Algumas reflexões

\section{4. “Quem somos nós?” - Instituto Terra, Trabalho Cidadania (ITCC)}

\section{Apresentação}

Tomei conhecimento do projeto "Quem Somos Nós?" no primeiro semestre de 2009, por meio de uma colega da Pós-graduação, mestranda em Psicologia e uma das realizadoras do projeto. Depois de compartilhar com ela de meu objeto de pesquisa e minha atuação no GDUCC, ela me convidou para participar de um curso de "Capacitação da Metodologia do Projeto Quem Somos Nós?”.

O curso ${ }^{188}$ ocorreu na sede do Instituto Terra, Trabalho e Cidadania (ITCC) e foi fechado para convidados que realizavam projetos em estabelecimentos prisionais. A maioria das

\footnotetext{
${ }^{187}$ Manual de Reintegração Social, SAP.

188 , 19 e 20 de abril de 2009.
} 
informações em relação ao projeto é fruto dos três dias do curso, que passei na companhia de suas realizadoras e executoras, além dos outros participantes que compartilhavam de suas experiências.

De início, cabe louvar a iniciativa dessa Capacitação, que tinha uma dupla finalidade: compartilhar a metodologia do projeto, submetendo-a à avaliação externa. O curso reuniu pessoas que propunham intervenções no cárcere para troca de experiências, e difundiu a metodologia utilizada pelo ITCC, de forma que pudesse ser discutida por pessoas exteriores à instituição e replicada em outros projetos.

Além do curso e das conversas em torno dele, serviram como fonte para dados sobre “Quem Somos Nós?” o site do ITCC ${ }^{189}$ e a cartilha do projeto “Quem somos nós?”190.

Como as profissionais do projeto, e mesmo do ITCC, são quase todas mulheres, utilizarei o feminino para me referir às executoras do projeto (também chamadas "oficineiras", por promoverem as oficinas) e estagiárias.

\section{a) Título do projeto}

"Quem somos nós?" O nome do projeto surgiu do desejo das realizadoras de que cada participante pudesse refletir acerca de sua trajetória enquanto cidadã e mulher.

\section{b) Realizadores, idealizadores, parcerias e convênios}

O projeto foi desenvolvido pelo Instituto Terra, Trabalho e Cidadania - ITTC, patrocinado pela Petrobrás (Programa Desenvolvimento e Cidadania).

O ITCC é uma organização não-governamental, com sede em São Paulo-Capital, constituída em outubro de 1997 por profissionais que atuam em defesa dos direitos dos cidadãos. Entre seus objetivos está a sensibilização do Estado e da sociedade para que sejam implementadas leis e políticas públicas que diminuam os efeitos da exclusão, e a própria exclusão.

\footnotetext{
${ }^{189}$ http://www.ittc.org.br/web/, acesso 12/02/2010.

${ }^{190}$ Publicação elaborada pela equipe técnica do Projeto, s.d.
} 
Além do referido projeto, o Instituto, fundamentado na perspectiva de instrumentalização dos cidadãos para defesa e garantia de seus direitos, vem produzindo publicações ${ }^{191}$ destinadas a orientar e divulgar informações para o exercício pleno da cidadania; duas publicações já foram produzidas, ambas dirigidas à população carcerária: Manual dos direitos das presas (2001) e em seguida, o Manual dos Direitos dos Presos.

Ademais, desde 2001, o ITCC presta assistência jurídica individual às presas estrangeiras na cidade de São Paulo.

\section{c) Estabelecimento(s) prisional (is) onde se realiza}

Nos anos de 2007 e 2008, o grupo atuou na cidade de São Paulo nas Penitenciárias Femininas da Capital (PFC) e de Santana (PFS). As duas penitenciárias, apesar de sua proximidade física, são completamente distintas. Enquanto que a da Capital conta com cerca de 800 presas e uma estrutura razoável- a grande maioria das presas trabalha e estuda- a PFS abrange um contingente muito maior, cerca de 3000 presas, em uma precária estrutura física e institucional, com poucas oportunidades de emprego ou estudo para as presas. Por essa disparidade de oportunidades o projeto se concentrou na PFS.

Além das duas penitenciárias, o ITCC realizou oficinas no Centro de Atendimento Hospitalar à Mulher Presa (CAHMD) e no Centro Hospitalar do Sistema Penitenciário, onde ficavam recolhidas as presas grávidas ou recém parturientes com seus bebês.

\section{Objetivos}

O projeto tinha como objetivo incentivar reflexões junto às mulheres que estão presas, por meio de oficinas temáticas. A proposta do projeto era de que as oficinas funcionassem como um espaço de reflexão, ao mesmo tempo diferente da sala de aula e distante de uma abordagem terapêutica.

Foram objetivos específicos do projeto:

$>$ proporcionar a reflexão e o desenvolvimento de ideias dobre a perspectiva de direitos humanos.

$>$ fomentar políticas de gênero no sistema prisional

\footnotetext{
${ }^{191}$ Todas disponível no site http://www.ittc.org.br/web/, acesso 12/02/2010.
} 
> conhecer o público a quem o projeto se destinava, a partir da própria experiência de vida das mulheres encarceradas.

\section{Público alvo, seleção dos participantes e número de pessoas envolvidas}

O público alvo desse projeto eram as mulheres presas nos estabelecimentos penitenciários da capital paulista, abrangendo inclusive dois Centros Hospitalares, aonde atendiam as mulheres gestantes ou que estavam com seus bebês.

As inscrições eram voluntárias e abertas a todas as presas, sem qualquer processo de seleção. Porém, de acordo com as executoras, apesar da publicidade da divulgação das oficinas (cartazes no pátio), algumas interessadas não conseguiam se inscrever, uma vez que o recebimento das inscrições acabava ficando a cargo das lideranças do presídio.

O único requisito para ingressar no projeto era não ter participado anteriormente do grupo. Porém, segundo as executoras, na PFS, houve pressão para que as presas que estivessem na escola fossem as escolhidas para participar do projeto.

A receptividade e motivação do projeto foi diferente em cada uma das Penitenciárias. No relato de uma coordenadora, como na PFC havia diversos trabalhos e cursos à disposição, as presas eram mais seletivas, e buscavam saber mais sobre a proposta do grupo antes de aceitar participar. Já na PFS, pela carência de tais atividades, as presas tinham interesse imediato no trabalho, ou em qualquer atividade que as ocupasse por um tempo.

Os grupos eram formados por aproximadamente quinze mulheres com diversos perfis. Quando se propôs às presas que os grupos fossem formados por faixa etária, elas rejeitaram a ideia, afirmando que preferiam que "fosse tudo variado".

\section{Metodologia}

O projeto consistia em oficinas educativas para grupos de aproximadamente 20 presas. As responsáveis pelas oficinas (“oficineiras") eram três técnicas (duas assistentes sociais e duas psicólogas) contratadas do Projeto. Cada uma delas, juntamente com uma estagiária, compunha uma equipe. Em cada uma das visitas aos estabelecimentos penitenciários, as três equipes dividiam-se nos pavilhões e coordenavam três grupos simultaneamente. 
Para cada grupo estava previsto um encontros semanal, com duas horas de duração, durante 6 semanas. Em cada encontro era trabalhado um tema diferente, assim distribuídos: 1. apresentação do projeto; 2. violência; 3. cidadania; 4. sexo e amor; 5. violência e gênero; 6. avaliação e encerramento. Ao final dos seis encontros, havia uma pequena formatura com entrega de diplomas e camisetas do projeto.

Além dos debates em grupo, um questionário individual era aplicado com o intuito de conhecer mais aquelas mulheres encarceradas, incluindo perfil sócio-demográfico e sua experiência com o sistema de justiça. De acordo com as "oficineiras", as conversas individuais no momento de aplicação do questionário acabaram por se revelar um espaço privilegiado de diálogo com as presas, que puderam compartilhar suas histórias de vida, o que ia muito além do objetivo de coleta de dados.

No primeiro dia de encontro, o grupo acordava um contrato acerca das regras de funcionamento do mesmo (denominado "termo de convivência"), cujo conteúdo variava de acordo com cada grupo, e era feita a escolha de um nome que o identificasse . Segundo o relato das técnicas do projeto, a maioria dos nomes escolhidos fazia alguma alusão à guerra, como "guerreiras da fé" ou "guerreiras fênix" (um dos nomes mais populares). Esse dado revela a representação da experiência prisional como uma guerra, na qual as presas, apropriando-se do mito da Fênix, identificam-se com a força daquele que renasce das cinzas.

A escolha de um nome conferia uma identidade ao grupo, e permitia a diferenciação dos diversos grupos formados pelo projeto. Percebi que essa simples técnica de auto-nomeação engatilhava uma primeira discussão interna quanto às expectativas dos participantes e despertava uma sensação de pertencimento, ainda que momentânea, entre seus participantes; logo, sugeri que passássemos a adotá-la no GDUCC, o que vêm sendo feito desde o segundo semestre de 2009.

A cada encontro, atividades de aquecimento corporal antecediam os debates sobre o tema da semana, cuja discussão era pautada pelas questões trazidas pelas presas. Ademais, o grupo estimulava a produção, por parte das presas, de desenhos, textos, letras de músicas, de forma que elas manifestassem sua forma de apropriação do tema. 
As presas que comparecessem em ao menos quatro das seis reuniões tinham direito a um certificado, que é registrado no prontuário com o nome de "voto de louvor". Os certificados são entregues em uma cerimônia de confraternização, que reúne os três grupos que realizaram as oficinas simultaneamente. Nessa cerimônia, as presas são chamadas nome por nome, são fotografadas, ouvem música, e o que é muito valorado em uma prisão: recebem refrigerante gelado.

Na PFS, o trabalho era feito na radial (espaço entre um pavilhão e outro). Apesar do projeto ter conseguido uma sala própria destinada às atividades, preferiu ficar no espaço no meio da galeria. Ali teria maior visibilidade, e potencial para alcançar mais gente, interagindo com o espaço do pavilhão.

$\mathrm{Na} \mathrm{PFC}$, as oficinas eram realizadas na escola. Na avaliação das executoras, o espaço da escola dificulta que elas tenham contato com a prisão como um todo. Esse isolamento pode trazer algumas dificuldades, como a de identificar o "clima" do dia, alguma anormalidade na dinâmica prisional, ou mesmo para interpelar acerca da ausência de uma das participantes.

No Centro de Atendimento Hospitalar à Mulher Presa (CAHMD) e no Centro Hospitalar do Sistema Penitenciário, as oficinas costumavam ser realizadas nos quartos, ou quando possível, no pátio do hospital.

\section{Histórico e duração do projeto}

A primeira edição do projeto foi no ano de 2007. No ano de 2008, o ITCC renovou o convênio com a Petrobrás por mais um ano. Já em 2009, não conseguiu-se a renovação do patrocínio e, levando ao fim do projeto.

\section{Inserção no campo prisional}

O grupo não teve dificuldade para realizar seu trabalho nas Penitenciárias Femininas, principalmente pelo fato de que a entidade promotora do projeto, o ITCC, presta a mais de dez anos atendimentos às mulheres estrangeiras presas no Estado de São Paulo ("Projeto Presas Estrangeiras"), pautado no Protocolo de Intenções firmado entre o Instituto e a Secretaria de Administração Penitenciária do Estado, renovado anualmente. 
Segundo Heidi Ann Cerneka ${ }^{192}$, presidenta do ITCC, o grupo teve problemas de acesso à penitenciária especificamente em 2006, devido ao aumento da disciplina e fechamento dos estabelecimentos prisionais decorrentes dos ataques do PCC em maio daquele ano.

\section{Relação com o pessoal penitenciário}

A proposta inicial do grupo era que tanto as agentes penitenciárias quanto as presas se envolvessem com o projeto. Porém, devido às dificuldades de logística, o trabalhou ficou concentrado nas presas, com uma edição com funcionários da parte administrativa na Escola de Administração Penitenciária (EAP), na formação dos agentes penitenciários (ASP).

Segundo relato das executoras do projeto, no início as oficinas eram realizadas sem nenhuma ASP por perto. Mais tarde, elas passaram a "vigiar' a dinâmica dos encontros.

\section{Principais dificuldades}

Uma das principais dificuldades apontadas pelas realizadoras foi a de traduzir os pressupostos e objetivos do grupo em atividades concretas. Essa dificuldade pareceu compartilhada pelos coordenadores do GDUCC, durante as diversas discussões de planejamento que antecediam cada edição.

Outra dificuldade explicitada foi a de lidar com a "postura defensiva" na qual se colocavam as presas, fruto da desconfiança em relação ao projeto. Segundo a percepção das realizadoras, o maior medo era a repercussão no pavilhão de suas falas no grupo. Isso ia sendo superado com o passar dos encontros, com o estabelecimento de uma relação de confiança com as presas.

\section{Impacto do trabalho e avaliação}

$\mathrm{Na}$ última reunião de cada grupo, após uma retrospectiva dos encontros, as participantes avaliavam o projeto. Segundo as executoras, o feedback que recebiam das presas era no sentido de que "vocês trazem a rua, a alegria".

${ }^{192}$ Em coversa durante o Curso de Capacitação. 
A ideia de que as pessoas da sociedade civil "trazem a rua", ou "um ar fresco", para dentro no cárcere, foi muito comum aos presos e presas participantes dos projetos que analisei na presente pesquisa.

\section{Resumo do programa das seis oficinas e das temáticas respectivas}

A seguir, apresento um resumo do programa de oficinas do "Quem somos nós?". A descrição das oficinas ilustra o desenvolvimento das propostas do grupo para cada um dos seis encontros. Ademais, a leitura dos tópicos revela o tipo de abordagem do grupo em torno dos três temas centrais das oficinas: Violência, Cidadania e Gênero.

- 1 Oficina: Apresentação $^{\text {a }}$

- boas vindas

- escuta das expectativas

- apresentação do projeto e proposta dos encontros

- apresentação pessoal

- reconhecimento de temas importantes por grupo

- $2^{\mathrm{a}}$ Oficina: Violência

- recorte: violência invisível, sistemática e não-aleatória, "violência estrutural"

- foco na responsabilidade do estado

- seletividade do sistema penal

- romper com a naturalização da violência

- legitimar a indignação coletiva

- debate sociedade $\mathrm{x}$ consumismo

- amenizar sentimento de culpa individual

- $3^{\text {a Oficina: Cidadania }}$

- conceito de cidadania

- quando se sentiram cidadãs?

- igualdade no exercício da singularidade

- 2 dimensões: direitos civis e políticos, participação, igualdade.

- estigma e preconceito

- $4^{\mathrm{a}}$ e $5^{\mathrm{a}}$ Oficinas: Gênero 
- Sexo e amor

- aproximação dos temas a partir da experiência das participantes

- relações desiguais de gênero

- relação mãe-filho

-estereótipos femininos e masculinos

- relacionamentos homo-afetivos

-visita íntima

- ausência de visita dos companheiros

- Violência contra a mulher

- reconhecer e nomear os tipos de violências

- compartilhar experiências

- refletir acerca de preconceitos que envolvem o tema

- conquistas das mulheres

- lei "Maria da Penha"

- relação da mulher com a polícia

- $6^{\mathrm{a}}$ Oficina: avaliação e encerramento

\section{Algumas reflexões}

Os objetivos da intervenção no cárcere estavam bem definidos e condizentes com o formato do projeto. Os temas a serem trabalhados nas oficinas aparecem bem delineados pelo grupo, e manejados a partir de vocabulários e técnicas que garantia sua compreensão por parte das participantes. Ademais, a proposta de discussão dos temas era dialógica, no sentindo de permitir a escuta e a fala do outro no debate. As discussões propostas pela equipe do projeto não tinham por objetivo levar um ensinamento moral ou um código de conduta às presas, mas incentivar que as mesmas falassem desde sua própria experiência, e construíssem suas próprias reflexões.

O trabalho anterior desenvolvido pela entidade promotora do projeto (ITTC) nas Penitenciárias (PFC e PFS) em que foram realizadas as oficinas foi muito importante para a sua inserção no meio prisional. Essa experiência contribuiu para a credibilidade do projeto no meio penitenciário, e para que o grupo reunisse conhecimentos prévios sobre a prisão e o público do projeto. 
A grande maioria das oficinas foi concentrada em duas penitenciárias femininas da cidade de São Paulo. Nesse sentido, a condução do projeto por equipes fixas em estabelecimentos prisionais específicos contribui para a repercussão do projeto na unidade prisional, e para que o grupo construa uma rede de relações no cárcere com funcionários, presos e administração prisional.

O recorte de gênero da intervenção, e de forma geral da entidade promotora, foi determinante no projeto. O ITTC é uma ONG basicamente composta por mulheres que atuam especialmente na defesa dos direitos das mulheres encarceradas.

Da mesma forma, as três equipes do projeto eram formadas basicamente por mulheres ${ }^{193}$, que atuavam em unidades femininas. Os temas abordados nas oficinas estavam diretamente ligados à problemática da mulher presa. Em especial, destaco a atuação do grupo nos centro hospitalares penitenciários, que abrigam presas no momento delicado da maternidade recente (com vistas à separação do bebê), ou em condições debilitadas de saúde, público para o qual a visita externa e a ampliação de espaços de diálogo tem um grande valor.

O formato de seis encontros, divididos por temas com início e final demarcado, contribuiu para a clareza da proposta. Alguns rituais adotados pelo projeto para encerramento e finalização das atividades contribuíram para a identificação das participantes com o grupo. A cada início de bloco de oficinas, o grupo elegia um nome que o identificasse, e ao final, as presas participavam de uma cerimônia festiva de entrega de diplomas, na qual ganhavam uma camiseta do projeto (a mesma que a equipe de "oficineiras" utilizava).

O uso de camisetas roxas pela equipe funcionou para identificar a presença das pessoas do projeto no cárcere, e difundir a marca do grupo dentro dele. A camiseta se tornou objeto de desejo das presas participantes (e até das não-participantes). Além de ser cobiçada como mais uma peça de roupa bonita, a uniformidade do vestuário representa uma integração em um coletivo além do carcerário, neste caso, formado por um grupo de mulheres em busca de sua identidade.

\footnotetext{
${ }^{193}$ Com exceção de um estagiário do sexo masculino que compôs uma das equipes.
} 
Ainda que esse formato do projeto, com alta rotatividade das participantes, tenha possibilitado o envolvimento de muitas presas nos seus dois anos de existência, o número de seis encontros proposto para cada grupo é pequeno. Segundo uma das executoras do projeto, "quando o grupo está ganhando proximidade, acaba". Logo, seria interessante que o formato fosse pensado a partir da ampliação do número de oficinas por cada grupo, para que pudessem aprofundar as reflexões e discussões propostas.

Infelizmente, a continuidade do projeto dependia da renovação do convênio com a Petrobrás no ano de 2009. Isso não ocorreu, dando fim a dois anos de uma intervenção bem sucedida no cárcere. O fim prematuro é um risco para qualquer projeto que tem sua continuidade condicionada a uma única fonte de recursos. Foi esse convênio, entretanto, que viabilizou materialmente o projeto, com pagamento dos profissionais envolvidos, material e demais custos.

Ao firmarem um convênio com entidades da sociedade civil, o poder público ou a iniciativa privada esperam um mínimo de projeção social e midiática. Por isso, muitos dos produtos que a entidade se compromete a entregar em um convênio estão relacionados diretamente com a visibilidade social do projeto e do nome de seus apoiadores.

No caso do "Quem somos nós?", entre as exigências do convênio estavam a promoção do curso de "Capacitação da Metodologia do Projeto Quem Somos Nós?" (do qual participei), e de um seminário aberto para exposição da intervenção e seus resultados. As duas iniciativas, ainda que trabalhosas aos olhos das executoras do projeto, funcionaram como ferramentas para difundir o grupo, democratizar o conhecimento e ampliar os espaços de discussão da intervenção no cárcere.

\section{5. “Curso transdisciplinar de criminologia penitenciária e execução penal"- Instituto de Ação Contra Cena (IACC)}

\section{Apresentação}

O Instituto de Ação Contra Cena (IACC) é uma ONG criada em 2002, com o intuito de suprir a falta de um serviço público essencial: o apoio ao egresso na forma de patronatos em São Paulo. 
Entre os anos de 2005 e 2006, o IACC concentrou suas ações na prestação de serviço ao egresso. Segundo Patrícia, fundadora e presidenta da ONG, o grupo buscou trabalhar de "uma forma não assistencialista, olhando para o egresso como um indivíduo participante e ativo no processo de reintegração dele".

Já no ano de 2008, como detalharei mais adiante, o IACC muda seu público alvo e lugar de atuação, a partir da proposta de um projeto denominado "Curso transdisciplinar de criminologia penitenciária e execução penal". Apesar de denominado "Curso" por comportar aulas preparatórias, as aulas estão voltadas para a atividade prática, que consistiu num trabalho desenvolvido pelos participantes junto às internas da Penitenciária Feminina de Santana, nos anos de 2008 e 2009.

A ideia básica que norteia o trabalho é basicamente a mesma do GDUCC: promover um diálogo construtivo entre os segmentos participantes, sempre na linha da reintegração social e do respeito às individualidades.

O Curso teve dois coordenadores: Daniel, professor de direito penal e advogado criminalista, e Patrícia, psicóloga com experiência de mais de seis anos em projetos no cárcere. Ambos participaram de diversas edições do GDUCC (Patrícia inclusive está no GDUCC desde sua fundação), e atualmente coordenam em dupla um dos grupos do GDUCC na Penitenciária Parada Neto, em Guarulhos.

A afinidade teórica entre os dois grupos, somada ao fato dos coordenadores atuarem também no GDUCC, possibilitaram um jogo de espelhos interessante, na definição de suas proximidades e diferenças, que serão abordadas sucintamente a seguir.

As informações abaixo descritas tiveram como fonte duas entrevistas e inúmeras conversas informais com os coordenadores do Curso, além de material documental como projeto, relatório dos participantes e publicações sobre o grupo.

A entrevista com Patrícia, coordenadora do Curso, foi a principal fonte dos dados aqui descritos. Registrei esta entrevista, realizada em maio de 2010, registrada com gravador. 


\section{a) Título dos projeto}

"Curso transdisciplinar de criminologia penitenciária e execução penal"

b) Realizadores, idealizadores, parcerias e convênios

Realizado pelo Instituto de Ação Contra Cena (IACC) e coordenado pela psicóloga Mônica Soligueto e pelo advogado Filipe Fialdini em 2009, em parceria com a Associação dos Advogados de São Paulo (AASP).

\section{c) Estabelecimento(s) prisional (is) onde se realiza}

Penitenciária Feminina de Santana (PFS)

\section{Objetivos}

Além de propiciar conhecimentos teóricos gerais de criminologia, o curso teve como principal objetivo promover uma nova forma de comunicação entre o cárcere e a sociedade livre, através de um trabalho interventivo, que proporcionasse aos envolvidos um espaço de discussão e reflexão concernente à dinâmica criminal e ao processo de reintegração social, pressupondo-se um papel ativo de todos os participantes do grupo.

\section{Público alvo, seleção dos participantes presos e números de pessoas envolvidas}

O curso foi aberto a estudantes e profissionais de todas as áreas, e tem como público-alvo estudantes, advogados, sociólogos, psicólogos e demais interessados em criminologia penitenciária.

Nas duas primeiras edições, o número de participantes manteve-se estável: dez alunos mais os dois coordenadores. Interessante marcar que, como ocorre em muitos projetos sociais, as mulheres foram maioria absoluta nas duas edições do curso: de dez participantes, nove eram do sexo feminino.

Já as participantes presas eram em número de vinte, aproximadamente. De acordo com Patrícia, "a gente já solicita trinta porque sabe que com o passar do tempo vão ficar em torno de quinze, treze".

Patrícia confirma a dificuldade, enfrentada por outras entidades, de conseguir que seja atendida sua a solicitação quanto ao perfil de preso: “A seleção das presas não foi feita por 
nós. O perfil seria aquelas que estivessem próximas ao fim de cumprimento de pena e que não recebessem visitas, que não participassem de atividades... mas o perfil não foi muito atendido".

No caso narrado, o Centro Penitenciário, responsável por selecionar os presos, passou essa incumbência; ainda segundo Patrícia, "a própria diretora admite que a escolha não é feita por ela. Ela solicita para uma das líderes da unidade que faça a escolha e esta pessoa que escolhe". Essa forma de seleção dos participantes, se inscreve em uma forma de gerenciamento compartilhado do cotidiano prisional, entre administração penitenciária e facção criminosa ${ }^{194}$, tema que aprofundei na minha dissertação de mestrado (Braga, 2008).

\section{Metodologia}

O curso tinha a duração de três meses. No primeiro mês, era realizada a parte teórica. Nos outros dois meses, ocorriam os nove encontros na penitenciária, seguidos de reuniões de supervisão com a psicóloga-coordenadora do grupo. Essas atividades correspondiam à carga horária de 51 horas, divididas em 9 horas de aulas expositivas, 22 horas de visitação à PFS e 22 horas de supervisão.

A metodologia e dinâmica do Curso eram muito parecidas com as propostas pelo GDUCC. A cada visita da penitenciária, elegia-se dois coordenadores responsáveis pelo encontro. As dinâmicas eram elaboradas pela coordenação do Curso, e repassadas aos "coordenadores" de cada encontro, que deveriam aplicá-las. Além disso, a cada semana um aluno "relator" era designado para escrever um pequeno relatório sobre o encontro.

As supervisões com a psicóloga-coordenadora do curso ocorriam no dia seguinte às visitas à Penitenciária, e tinham o intuito de trabalhar questões, incômodos, frustrações e percepções que impactaram individualmente ou coletivamente os alunos do Curso.

\section{Histórico e duração do projeto}

Anteriormente ao Curso, o IACC realizou voluntariamente, nos anos de 2005 e 2006, o "Projeto de intervenção interdisciplinar-comunitário na política criminal voltada a egressos

\footnotetext{
${ }^{194}$ De acordo com o narrado pelos coordenadores de projetos nas penitenciárias femininas, o Primeiro Comando da Capital (PCC) é atuante tanto na PFS, quanto na PFC.
} 
do sistema penitenciário", desenvolvido na sede, e com o apoio da Secretaria de Administração Penitenciária (SAP) de São Paulo.

A intervenção consistia em 12 sessões de "psicoterapia breve" com os egressos do sistema prisional. Paralelamente ao atendimento individual, formaram-se grupos de apoio aos familiares de egressos, que, segundo Patrícia, "também se sentiam presos devido à vergonha e o preconceito que sofriam".

Segundo a presidenta da ONG, o trabalho com egressos trazia uma série de dificuldades, principalmente porque o projeto era desenvolvido na SAP. "Era extremamente complicado levar o egresso para um espaço público que relembrava tudo o que ele passou na unidade prisional, então eles não compareciam, não aderiram”.

Logo, a partir de 2008, alguns membros do IACC, pensaram que seria interessante elaborar projetos para trabalhar dentro do presídio, já preparando as pessoas para quando elas deixassem a unidade prisional. Então decidiram levar "o GDUCC para o IACC com outra cara", dando origem a um novo projeto: "Curso Transdisciplinar de Criminologia Penitenciária”. Segundo Patrícia, “o curso foi idealizado e coordenado por pessoas que haviam passado anteriormente pela experiência do GDUCC, do qual, portanto, é uma ampliação, o que posso dizer com muita felicidade".

$\mathrm{Na}$ primeira oportunidade, o Curso foi promovido exclusivamente pelo IACC, e ocorreu entre abril e julho de 2008. Dezesseis pessoas participaram dos encontros, sendo dois coordenadores, seis visitantes - em sua maioria, advogados e estudantes de direito, além de uma agente penitenciária -, e oito presas. Na segunda edição, o programa foi produto de uma parceria entre o Instituto de Ação Contra Cena (IACC) e a Associação dos Advogados de São Paulo (AASP), tendo sido iniciado em setembro de 2009, com término em dezembro de 2009. Ambas edições tiveram suas práticas na Penitenciária Feminina de Santana (PFS).

\section{Inserção no campo prisional}

Como outros grupos aqui analisados, as atividades do IACC foram realizadas em uma Penitenciária Feminina da cidade de São Paulo. O contato com a Penitenciária foi feito por meio do Professor Alvino Augusto de Sá que, nos mais de trinta anos de trabalho no 
sistema prisional paulista, acumulou muitos contatos e reconhecimento. Ainda assim, Patrícia aponta que "a negociação foi bastante demorada"

Segundo a presidenta do IACC "a escolha da Penitenciária Feminina de Santana se deu por conta da facilidade de acesso. Depois, porque existem poucos trabalhos nas unidades femininas, todo mundo quer trabalhar com o masculino. Inclusive os alunos questionavam a gente, porque não na masculina?"

A afirmação de Patrícia pode ser matizada por outros dois outros dados do campo:

1) na pesquisa exploratória, levantei uma série de projetos que acontecem nas Unidades Femininas, os quais parecem ser em número maior do que as femininas. 2) o GDUCC sempre realizou suas atividades em penitenciárias masculinas, e a cada edição é questionado pelos acadêmicos sobre a possibilidade de estender o trabalho a um centro feminino.

Essa discussão de gênero x prisão, fundamental para compreender as especificidades da penitenciária feminina, e, logo, da intervenção social nela realizada, voltará a ser problematizada, em item próprio no final deste Capítulo.

\section{Relação com o pessoal penitenciário}

Apesar da direção da PFS apoiar a iniciativa e se orgulhar de ter o projeto naquela unidade, o grupo não tinha um suporte do pessoal penitenciário que fizesse a ponte entre a prisão e a entidade, e que garantisse a regularidade do trabalho do grupo no interior da penitenciária.

Principalmente na segunda edição do curso, em 2009, foi negada por diversas vezes a entrada do grupo na penitenciária, sem que o motivo estivesse claro. De acordo com Patrícia: "O que aconteceu muito na segunda edição era que no dia da visita nos ligavam informando que não poderíamos ir, e a gente percebeu que tinha algo estranho nas informações: para nós era passado um motivo, para as presas era passado outro. Então, quando o grupo se encontrava novamente com as presas, tinha esse embate de informações." 
Para ilustrar a relação das presas com os funcionários do sistema, narro brevemente duas histórias contadas por Patrícia que apontam para os limites de interação preso- funcionário do sistema.

A primeira edição do Curso contou com a participação de uma ASP que havia trabalhado na PFS por vinte anos, tendo sido inclusive diretora da Unidade Prisional. De início, a participante ocultou essa informação da coordenação do curso, porém, segundo Patrícia, "algumas presas passaram a reconhecê-la, ademais o comportamento dela era diferente, ela conhecia os diretores, cumprimentava todo mundo, os funcionários...e as presas se sentiram meio traídas". Houve acusações que a participante/ASP estaria no grupo para vigiar as presas.

A segunda edição também teve entre seus participantes um ex-ASP, atualmente advogado criminalista. No relato de Patrícia, "esse sofreu bastante, as meninas foram muito duras com ele, e ele passou a se sentir rejeitado".

Na primeira situação, além da condição de ASP, o que estava em jogo era a honra das participantes, já que ela só revelou ao grupo sua função depois de alguns encontros. Já no segundo caso, apesar do participante não ser mais ASP e ainda ter compartilhado sua biografia com o grupo, ele não foi de forma alguma aceito pelas presas.

Ambas histórias apontam para limites na aproximação desses do coletivo de presos e presas com os funcionários penitenciários, tema que será retomado no próximo capítulo.

\section{Principais dificuldades}

Conforme narrado acima, a principal dificuldade enfrentada para realização do "Curso transdisciplinar de criminologia penitenciária e execução penal” foi o contato e comunicação entre os coordenadores do curso e a unidade prisional.

Em um segundo momento, a maior dificuldade foi fazer o grupo de presas entender que não se tratava de um grupo assistencialista, e ainda assim, aceitar participar, aderir ao grupo, porque, segundo a coordenadora, "elas vão com a expectativa o que eu ganho com isso?, e quando elas entendem que não é um serviço jurídico, não é um serviço 
psicológico, é um espaço de escuta, de conhecer o outro... isso é complicado, muitas meninas deixam de participar."

Além do mais, a falta de reconhecimento e de espaço para propostas desse tipo no campo da psicologia também é apontada por Patrícia como uma das dificuldades: "é um trabalho pouquíssimo reconhecido, as pessoas gostam, os presos, os familiares, os egressos, a própria instituição diz que é importante, mas você tem pouco apoio para desenvolver o projeto. Na psicologia especificamente, é um trabalho que não existe, de formiguinha, de mostrar para as pessoas que é um trabalho que pode ser realizado. O Conselho Federal de Psicologia ainda está preso à questão da avaliação, exame criminológico. Dentro da psicologia, não se tem essa visão de trabalhar em outro foco, da reintegração, de preparar o indivíduo para voltar pra sociedade. Existe muito a preocupação de traçar o perfil do indivíduo"

Uma quarta dificuldade advém do alcance e perpetuidade dos trabalhos de reintegração social. “A impressão que a gente tem é que está fazendo um trabalho, mas é um trabalho que vai... vai resolver o que? Porque às vezes você não consegue, você fala com a pessoa, você passa algumas ideias para ela...e essa é uma angústia que a gente divide na supervisão, tá, e daí? (...) mas se a gente quisesse falar da realidade mesmo, teria que ver é, então você vai ter dificuldade de arrumar emprego, vai ser tudo dificil..."

\section{Reflexos do trabalho e avaliação}

A intervenção proposta pelo Curso parece ter sido bem recebida na unidade, e impactado de alguma forma a dinâmica prisional. Diversas presas que não participaram demonstravam interesse em se inscrever para uma próxima edição.

Ademais, os coordenadores do Curso souberam pelas presas que algumas vezes elas replicavam no interior da prisão as dinâmicas que tinham participado, e que alguns temas tratados no Curso tinham se tornado o "assunto da semana" na unidade.

Na avaliação de Patrícia, falta o comprometimento de psicólogos e de pessoas de outras áreas no trabalho de intervenção no cárcere: "Queria que a psicologia se abrisse. A gente sempre brinca que seria bom se tivesse uma dona de casa, pessoas de diversos perfis participando...". 
Essa ideia de diversificar o perfil da pessoa que visita o cárcere para além dos advogados e estudantes de direito foi compartilhada por vários informantes desta pesquisa, inclusive por um dos presos participantes do GDUCC, conforme se apresentará no próximo capítulo.

\section{X. "Curso transdisciplinar de criminologia penitenciária e execução penal” e o GDUCC: algumas reflexões}

A ligação entre IACC e GDUCC está principalmente relacionada a algumas pessoas que participaram da história de ambos os grupos. Os coordenadores do "Curso transdisciplinar de criminologia penitenciária e execução penal" não só foram participantes do GDUCC como desde 2011 são coordenadores de um dos subgrupos do GDUCC.

O "Curso transdisciplinar de criminologia penitenciária e execução penal” foi proposto a partir da experiência anterior de alguns membros do IACC, em atendimento ao egresso e no GDUCC.

Logo, o Curso nasce da tentativa de adaptar e aprimorar o formato do GDUCC, aproveitando seus acertos e suprimindo suas falhas. As comparações entre os dois projetos é um exercício interessante para se discutir as diferentes formas que podem assumir um projeto de intervenção no cárcere.

Uma das críticas de Patrícia ao GDUCC foi que o grupo não garantia às supervisões um espaço privilegiado para as reflexões e discussões. Apesar de estarem previstas no GDUCC, as supervisões não aconteciam com a mesma frequência dos encontros ${ }^{195}$, e quando aconteciam, era mais um planejamento estratégico do que a elaboração de questões que apareceram do contato com o cárcere.

Já o programa do Curso destinava o mesmo tempo para as supervisões e para as visitas ao cárcere. De acordo com Patrícia, "a gente achava que era importante discutir algumas questões pessoais, o reflexo que isso tinha nos participantes do lado de fora, o preso fala um monte de coisa que mexe com quem está do lado de fora."

\footnotetext{
${ }^{195}$ Nos primeiros anos do GDUCC, realizávamos a supervisão improvisada depois de casa encontro na Penitenciária ou na FADUSP. Depois, passamos a reservar um encontro do grupo (a cada suas ou três visitas ao cárcere) para reunião de planejamento e supervisão na FADUSP.
} 
Uma dificuldade compartilhada pelos coordenadores em ambos os grupos foi conseguir constituir grupos heterogêneos e de caráter interdisciplinar, ou seja, que reunissem participantes com diversas formações e profissões.

Nesse sentido, o perfil dos participantes do Curso e do GDUCC era bastante parecido. Ambos eram compostos basicamente por estudantes do curso de direito. $\mathrm{Na}$ leitura de Patrícia, os grupos, ainda que abertos a profissionais e estudantes de diversas áreas, acabam atraindo sempre mais estudantes de direito, porque as pessoas de outras áreas "desconhecem a possibilidade desse trabalho e não entendem o objetivo". Além do mais, a divulgação e os meios em que circulam os participantes do grupo são, em geral, espaços jurídicos, o que acaba perpetuando a presença desses profissionais nos grupos.

A presença quase hegemônica dos profissionais do direito traz alguns problemas para os grupos, que deixam de beneficiar-se de outros saberes e outros recursos humanos na elaboração e execução dos projetos.

Patrícia comenta a dificuldade de envolver o profissional do direito com as atividade propostas, uma vez que ele "tem dificuldade de compreender como é ir à unidade prisional, não prestar acessória jurídica e ainda discutir algumas questões subjetivas, porque o profissional do direito é muito objetivo, muito direto nas questões. A dinâmica de grupo, por exemplo, quando a gente propôs essa aula, a maior dificuldade dos alunos foi entender porque essa aula, porque era importante, porque não chegar e propor um assunto ao invés de chegar com "brincadeirinha".

Certamente, a presença de uma psicóloga na coordenação do curso foi essencial para a elaboração e difusão das dinâmicas que serviriam de instrumento à intervenção no cárcere. Além do mais, o resgate do papel da supervisão após os encontros contribuiu para que as discussões fossem aprofundadas, e principalmente, para que os participantes da sociedade civil envolvidos com o projeto tivessem um tempo e um espaço para elaborar as questões suscitadas na interação com o cárcere.

O fato do projeto não estar vinculado ao modelo e às exigências em torno do GDUCC permite que sejam experimentados outros formatos de intervenção, e dá mais liberdade a seus executores. Por outro lado, a ausência de vínculo do projeto com uma instituição forte 
(tal como é a USP para o GDUCC) e a falta de apoio material constante para execução do projeto representam riscos à sua continuidade.

\subsection{Projeto Leiturativa - Fundação Escola de Sociologia e Política de São Paulo (FESPSP)}

\section{Apresentação}

Tomei conhecimento do Projeto Leiturativa através da pesquisa exploratória realizada na internet (ferramenta de busca Google) no primeiro semestre de 2010. Em seguida, entrei em contato com os responsáveis pelo projeto, e combinamos de eu acompanhar um dia de intervenção do grupo na prisão

Em julho de 2010, compareci a uma das sessões do projeto na Penitenciária Feminina do Butantã. Algumas informações e percepções foram extraídas do relato etnográfico e das conversas que tive no dia da visita à Penitenciária, quando pude conversar informalmente com algumas presas participantes e uma facilitadora do projeto. Foi a única oportunidade que tive de falar com um de seus idealizadores e coordenadores, que nesse momento não quis ser formalmente entrevistado, e tampouco que eu utilizasse o gravador.

A principal fonte de informação documental foi o artigo "Leiturativa: os limites da nossa intervenção" ${ }^{196}$, escrito em conjunto por seus idealizadores, Durvalino Peco, Eliana Asche e Wagner Paulo Silva.

Outras fontes importantes foram o site http://www.fespsp.org.br/leiturativa.htm e o blog http://projeto-leiturativa.blogspot.com/, no qual há noticias e relatos interessantes de alguns encontros do grupo, assinados por um preso-mediador do projeto.

\section{a) Título do projeto}

Leiturativa

b) Realizadores, idealizadores, parcerias e convênios

\footnotetext{
${ }^{196}$ Disponível no site: http://www.fespsp.org.br/noticias.detalhes.asp?seq=1569, acesso 12/11/11.
} 
O projeto teve início na Fundação Escola de Sociologia e Política de São Paulo (FESPSP), com a professora Evanda Paulino Verri, coordenadora acadêmica da Faculdade de Biblioteconomia e Ciência da Informação da FESPSP e orientadora do projeto. Em 2004, o aluno de biblioteconomia Durvalino Nascimento Peco e o bibliotecário Wagner Paulo da Silva idealizaram o projeto.

Nos primeiros anos, a FESPSP apoiava o projeto, com o pagamento de bolsa de estágio aos seus realizadores. Depois que os estudantes-realizadores se formaram, passou a contribuir com ajuda de custo.

No ano de 2010, a FESPSP foi contemplada no concurso de Fomento e Difusão de Produção Cultural do Governo do Estado promovido pela Secretaria Estadual de Cultura, e recebeu um aporte no valor de $\mathrm{R} \$ 60$ mil para a manutenção do "Projeto Leiturativa", e para dar continuidade à sua atuação no desenvolvimento de rodas de leitura em 26 unidades prisionais do Estado de São Paulo.

\section{c) Estabelecimento(s) prisional (s) onde se realiza}

De 2004 a 2009, o projeto foi desenvolvido em seis centros penitenciários de São Paulo, dos quais cinco são femininos. São eles o Centro de Progressão Penitenciária de São Miguel e as Penitenciárias Femininas de Franco da Rocha, do Tatuapé, do Butantã, da Capital e de Santana.

No ano de 2010, o grupo expandiu-se para outras unidades do Estado de São Paulo, totalizando 26 unidades prisionais.

\section{Objetivos}

Segundo seus idealizadores, o projeto Leiturativa tem como objetivo o incentivo à leitura, por meio de ações culturais e pela oferta de meios de informação que, em conjunto, proporcionam aos participantes o acesso ao conhecimento, à cultura e à leitura. $\mathrm{O}$ grupo pretende despertar e desenvolver o prazer pela leitura e a imersão no universo transformador dos livros, dos filmes, das músicas e de outras formas artísticas e narrativas, principalmente aquelas que exploram os valores humanos e experiências cotidianas reelaboradas esteticamente. 
A proposta de trabalho do "Leiturativa" distancia-se de qualquer projeto de cunho assistencialista ou de apoio psicológico ao presidiário, uma vez que o grupo não possui habilitação para trabalhar nessas frentes.

As rodas de leitura nos estabelecimentos prisionais visam atingir os seguintes objetivos:

- oferecer aos participantes uma visão do panorama da produção literária em língua portuguesa de temas e assuntos variados ao interesse da comunidade envolvida.

- promover a ampliação de repertório de leitura desses sujeitos.

- oferecer aos participantes condições de desenvolver atividades variadas de leitura estimulada.

- promover atividades que permitam o tratamento intertextual dos materiais escritos, por meio de filmes, exposições artísticas, debates com produtores artísticos etc.

- favorecer atividades artísticas que tomem o texto escrito como elemento motivador das demais expressões. Promover atividades que podem decorrer da leitura, tais como: exercícios dramáticos, concursos de declamação, tratamento intertextual dos temas, produção de mural, produção de jornais internos, locuções radiofônicas etc.

\section{Público alvo, seleção dos participantes e número de pessoas envolvidas atendidas}

O público alvo são presos e presas do sistema penitenciário paulista. Cada turma é composta por aproximadamente 25 presos ou presas.

Em fevereiro de 2010, o Projeto ofereceu "Curso de Extensão gratuito de Formação de Mediadores de Leitura para atuação em unidades prisionais", aberto a pessoas da sociedade civil interessadas, com vistas ampliar o quadro de mediadores do projeto.

\section{Metodologia}

Ao explicarem a metodologia do projeto, os coordenadores se aproximam muito da ideia de "movimento inacabado" de Mathiesen (1974), mencionada no Capítulo 3 desta tese: "o projeto não surgiu de uma teoria pronta, mas constituiu, ao longo desses seis anos, uma espécie de metodologia própria, temperada pelos acertos e erros do grupo, especialmente, pela contribuição do público a que o projeto se destinava". 
O grupo desenvolveu uma metodologia de trabalho própria, construídas pelos alunos e colaboradores dentro dos presídios. A cada semana, o projeto propõe um texto, um filme ou uma poesia para o debate, que ocorre entre os presos e presos (em um grupo de aproximadamente 20 a 30 presos) e 2 mediadores.

As atividades ocorrem normalmente na biblioteca das unidades prisionais, ou em algum lugar adaptado para a atividade.

\section{Histórico e duração do projeto}

O projeto Leiturativa foi criado em 2004, por iniciativa de alunos do curso de Biblioteconomia da FESPSP. Foi mantido ao longo dos anos com recursos da própria Fundação. No ano de 2010, dá início a uma nova fase, em que se ampliam as ações em 25 presídios de São Paulo. Amplia-se também o número de mediadores

No ano de 2007, o projeto ficou como terceiro colocado, na Categoria Educação, do Prêmio Cidadania Sem Fronteiras, organizado pelo Instituto Sem Fronteiras e pela Universidade Presbiteriana Mackenzie. Em 2008, o Projeto foi selecionado pelo Ministério da Cultura no I Concurso de Pontos de Leitura, tendo recebido 500 livros, 1 microcomputador, 1 impressora e mobiliário que foram para a Biblioteca da Penitenciária Feminina do Butantã. A reinauguração da nova biblioteca aconteceu em outubro de 2009, agora com o nome de Biblioteca Cora Coralina, em homenagem à escritora goiana.

Em 2009, o projeto foi selecionado no Programa Ação Cultural, e contou com o apoio do Governo do Estado de São Paulo, por meio da Secretaria de Estado da Cultura, para realizar rodas de leitura nas unidades prisionais da Região Metropolitana de São Paulo. Esse trabalho foi desenvolvido durante o ano de 2010. No ano de 2011, como contrapartida aos recursos recebidos pelo projeto, a FESPSP realizou oficinas de leitura em duas escolas públicas da Capital.

Também no ano de 2010, o projeto foi contemplado com o IX Prêmio Laura Russo na categoria projeto social. Criado em 1998 pelo Conselho Regional de Biblioteconomia do Estado de São Paulo, o Prêmio Laura Russo tem o objetivo de divulgar e promover o reconhecimento da profissão de bibliotecário. 


\section{Inserção no campo prisional}

No final do ano de 2004, foi realizado um projeto piloto, com duração de quase um ano, na extinta Penitenciária Feminina de Franco da Rocha. Em 2005, a então Diretora da Penitenciária Feminina do Butantã tomou conhecimento do projeto, por intermédio de uma interna participante, e convidou o grupo para realizá-lo naquele centro prisional.

A partir de 2006 o projeto se expandiu para outras penitenciárias femininas e para o Centro de Progressão Penitenciária de São Miguel, conforme o quadro abaixo:

\begin{tabular}{|c|c|c|}
\hline Unidade Prisional & Período & Média de Público \\
\hline $\begin{array}{l}\text { Penitenciária Feminina } \\
\text { de Franco da Rocha }{ }^{197}\end{array}$ & $\begin{array}{l}\text { De setembro de } 2004 \text { à agosto de } \\
2005\end{array}$ & $\begin{array}{l}30 \text { presas / } \\
\text { uma turma semanal }\end{array}$ \\
\hline $\begin{array}{c}\text { Penitenciária Feminina } \\
\text { do Tatuapé }\end{array}$ & $\begin{array}{l}\text { De agosto de } 2005 \text { à janeiro de } \\
2006\end{array}$ & $\begin{array}{l}20 \text { presas/ } \\
\text { uma turma semanal }\end{array}$ \\
\hline $\begin{array}{l}\text { Penitenciária Feminina } \\
\text { Dra. Marina Cardoso } \\
\text { de Oliveira (Butantã) }\end{array}$ & $\begin{array}{c}\text { De março de } 2006 \text { à dezembro de } \\
2009\end{array}$ & $\begin{array}{l}80 \text { presas / } \\
\text { duas turmas semanais }\end{array}$ \\
\hline $\begin{array}{c}\text { Centro de Progressão } \\
\text { Penitenciária de São } \\
\text { Miguel }\end{array}$ & De março de 2006 à julho de 2009 & $\begin{array}{l}25 \text { presos/ } \\
\text { uma turma semanal }\end{array}$ \\
\hline $\begin{array}{l}\text { Penitenciária Feminina } \\
\text { da Capital }\end{array}$ & $\begin{array}{c}\text { De fevereiro de } 2007 \text { à dezembro } \\
\text { de } 2008\end{array}$ & $\begin{array}{l}20 \text { presas/ } \\
\text { uma turma semanal }\end{array}$ \\
\hline $\begin{array}{c}\text { Penitenciária Feminina } \\
\text { de Santana }\end{array}$ & $\begin{array}{l}\text { De julho de } 2006 \text { à dezembro de } \\
2006\end{array}$ & $\begin{array}{l}20 \text { presas/ } \\
\text { uma turma semanal }\end{array}$ \\
\hline
\end{tabular}

\section{Reflexos do trabalho e avaliação}

Apresento a seguir dois desdobramentos que considero reflexos do trabalho desenvolvido pelo "Leiturativa": um blog mantido por participantes do projeto e a experiência de um convidado participante descrita em um jornal de circulação nacional:

* Blog dos participantes do projeto

\footnotetext{
${ }^{197}$ Projeto piloto que serviu de base para continuidade do projeto
} 
O blog http://projeto-leiturativa.blogspot.com/, foi criado por um grupo de presos em regime semiaberto que participaram do projeto no Centro de Progressão Penitenciária de São Miguel.

Seus autores se autodenominam um "grupo de cabeças pensantes, que presos em regime semiaberto e inconformados com a realidade carcerária, nos unimos para dar continuidade ao Projeto com o objetivo de desinstitucionalizar, e contribuir para a ressocialização, através de roda de leituras, com livros, revistas, jornais, matérias de televisão e rádio, filmes e documentários, palestras de vários segmentos, e outros que contribuam para a finalidade à qual o Projeto foi criado".

O blog contem textos de autoria de diversos presos. As postagens de janeiro de 2011, por exemplo, reúnem uma série de interessantes relatos das experiências de presos que haviam saído (temporariamente) para as festas de fim de ano usando "tornozeleira eletrônica".

Porém, a maioria dos textos são de autoria do Sr. Letang ${ }^{198}$, cuja biografia pode ser reconstruída a partir de dados pessoais dispersos nos textos do blog. Ele é hoje mediador do Leiturativa e bacharel em Sociologia pela FESPSP. Foi o responsável pelo projeto quando estava preso no regime semiaberto do CPP de São Miguel. Seus textos narram sua trajetória pessoal na prisão e suas atividades à frente do "Leiturativa".

O mediador ${ }^{199}$ tem uma longa história com o sistema prisional. Segundo ele, esteve por 11 anos no regime fechado. Ficou aguardando por mais de três anos o cálculo de pena para a progressão para o regime aberto, o que ocorreu em 16/3/2011, sem nenhuma falta disciplinar. No semiaberto, ele buscou "estudar e construir uma nova história em minha vida, o que não foi fácil, e o trabalho externo em empresa privada. ... diante de tantas adversidades que o sistema carcerário na figura de seus agentes (Juízes, promotores, Diretores, Funcionários) me proporcionou negativamente, consegui frequentar o ensino médio e concluí-lo, depois iniciar curso superior e também concluí-lo (Bacharel em Sociologia)."

O Sr. Letang escreve o texto acima, e diversos outros, sob a perspectiva do preso. Porém,

\footnotetext{
${ }^{198}$ Aqui, optei por manter a nominação utilizada no blog, que é público.

${ }^{199}$ Postagem publicada em 15/01/ 2011.
} 
ele se apropria de uma série de recursos e instrumentais teóricos para escrever sua história, e propõe reflexões acerca do cárcere a partir de sua própria experiência. Para falar do processo de prisionização e atacar a pretensa função reabilitadora da prisão, o Sr. Letang cita Thomas Mathiesen, Michel Foucault, Donald Clemmer, Zygmunt Bauman, entre outros.

Algumas postagens do blog, assinadas como "projeto-leiturativa", assumem uma perspectiva institucional. Abaixo reproduzo trecho de um desses textos ${ }^{200}$ que representam os objetivos e o tipo de discurso do grupo:

"O primeiro passo para mudar a sua história é você que tem que fazê-lo e sozinho, o segundo passo já terás ajuda para escrever uma nova história. $\mathrm{O}$ Leiturativa está aqui para isso, incentivá-lo a fazer o primeiro passo em direção a mudança de vida, no segundo passo já estaremos com você para ajudá-lo a continuar a caminhar em rumo a uma cabeça pensante, que tem por objetivo mudar a história, que no passado foi escrita sem uma concordância verbal, sem adjetivo sem substantivo, sem pronome, e sem sujeito. mas que agora o sujeito estará presente em cada linha escrita, com seu devido pronome, substantivo, e adjetivo, e será nítida a concordância verbal"

* Uma experiência com o Leiturativa narrada no jornal

Em uma de suas colunas semanais ${ }^{201}$ na Folha de São Paulo, o psicanalista Contardo Calligaris descreveu sua experiência de participação em um dos encontros do projeto "Leiturativa" na Penitenciária Feminina do Butantã, situada na rodovia Raposo Tavares. Um dos coordenadores escreveu para Contardo, contando que o grupo ( de aproximadamente 25 mulheres) tinha discutido uma de suas colunas, e convidando-o para que ele participasse de um "encontro com o autor" na penitenciária.

Na mencionada coluna, o autor expos algumas das reflexões advindas do encontro com as presas, das quais destaco a seguinte:

"Na época em que trabalhei em instituições psiquiátricas fechadas, quando o expediente terminava e estava na hora de ir embora, no fim do dia, eu era acometido por uma tristeza profunda. Acabava de compartilhar um bom

200 Postagem de 26/01/2011

${ }^{201}$ A lealdade das mulheres, In Folha de São Paulo, Caderno Ilustrada, E14,18/02/10. 
tempo com os que estavam lá internados, e eis que, agora, eu ia embora, para uma casa, uma companhia, o convívio dos amigos. E eles, não; eles ficavam. A tristeza era uma espécie de culpa por abandoná-los no que era, de fato, uma desolação. Pois bem, ao sair da penitenciária do Butantã, não senti nada disso, pois não havia desolação. Não teria como fazer elogio maior à direção do presídio, à equipe que lá trabalha e às detentas que encontrei, pela resiliência de sua vontade de viver"

\section{Algumas reflexões a partir de um olhar comparado}

Patrícia, presidenta do IACC, coordenadora do "Curso transdisciplinar de criminologia penitenciária e execução penal" (2008 e 2009) e atualmente no GDUCC (2011), também teve uma participação no projeto "Leiturativa".

No ano de 2010, ela foi contratada pelo projeto para dar uma aula sobre psicologia na unidade prisional. Segundo ela: "uma aula bem prática, do dia-a-dia da prisão, de como você vai encarar o individuo que está preso". Ademais, Patrícia ajudou no processo seletivo dos mediadores das rodas de leitura, para ver quem tinha o perfil para trabalhar no cárcere.

Ao ser perguntada sobre os três projetos ${ }^{202}$, Patrícia apontou duas diferenças: o perfil dos participantes da sociedade civil e as temáticas que permeavam a intervenção. Os participantes do "Leiturativa não tinham o perfil jurídico, era mais o pessoal da área da educação... tinha psicólogos, pessoas que vinham de projetos sociais, de ONGs, Fundação Casa...".

Ademais, ao contrário do que ocorria no GDUCC e no "Curso transdisciplinar de criminologia penitenciária e execução penal”, o grupo não tinha nenhuma preocupação em discutir criminologia. Segundo Patrícia:

"Isso não faz parte do projeto. O projeto na verdade era ir dentro da unidade levar literatura. O foco é a literatura, discutir livro, autor (...) só que a literatura acaba despertando uma série de assuntos e ai entra em questões subjetivas, emocionais, ai eles achavam necessário ter uma psicóloga que falasse do assunto, tentasse colocar alguns limites na atuação".

Como mencionado acima, as rodas de leitura não tem a finalidade de realizar um trabalho terapêutico, no sentido de apoio psicológico individual, no cárcere. Essa clareza quanto ao

\footnotetext{
${ }^{202}$ Entrevista realizada em maio de 2010.
} 
objetivo e limitações do projeto justifica a preocupação do grupo em não despertar expectativas ou necessidades que não poderá atender.

Ao mesmo tempo, a perspectiva de que a "literatura acaba despertando uma série de assuntos e aí entra em questões subjetivas, emocionais" é muito positiva sob o ponto de vista da reintegração social. Qualquer que seja a intervenção no cárcere, ela pressupõe uma interação humana, imprevisível, que escape às discussões literárias, e é essa a dimensão reintegradora do trabalho.

Algumas presas participantes descreveram ${ }^{203}$ alguns impactos do projeto: "ajuda a abrir a mente, não me sinto presa", "a gente sai um pouco daqui", ou ainda, como "uma viagem para dentro de você, é uma coisa que a literatura te dá muito".

No "Leiturativa", a literatura aparece como um instrumento da reintegração social, um lugar de encontro das pessoas de dentro e de fora do cárcere. O diálogo aqui é intermediado pelos livros, que atuam como uma forma de ampliar o universo pessoal dos participantes, e despertar reflexões individuais e coletivas.

Os prêmios que o projeto ganhou no decorrer desses setes anos, e principalmente o apoio financeiro do Governo do Estado em 2010, foram reconhecimentos que contribuíram para o crescimento do projeto. Nesse período, além de ampliar o número de unidades prisionais atendidas, o projeto aumentou o número de participantes da sociedade civil, mediadores dos projetos.

A parceria com o poder público, conquistada após cinco anos de projeto, deu ao grupo um ano de aporte material. Mas contribuiu além disso para ampliação de seu alcance, e no processo de entrada dos mediadores nas 26 unidades prisionais pela qual o projeto passou.

$\mathrm{O}$ apoio do poder público institucionalizou uma prática que nasceu em âmbito local ${ }^{204}$. Especificamente entre os anos de 2004 e 2009, o projeto circulou por diversas unidades prisionais, ficando entre seis meses e um ano e meio em cada uma delas.

203 Programa ENTRELINHAS Cultura. Disponível no site http://www.youtube.com/watch?v=QKK0HuQ7b5Y, acesso 15/11/2011. 
Nesse período, o "Leiturativa" esteve por mais tempo em duas unidades especificas: quase quatro anos na Penitenciária Feminina do Butantã (PFB) e pouco mais de três anos no CPP de São Miguel.

As experiências que apresentei anteriormente como reflexos do projeto (o blog e a coluna no jornal), foram fruto da intervenção do "Leiturativa" em uma das duas unidades prisionais citadas. Ambos os retratos datam do ano de 2011, o que demonstra a permanência do grupo nessas unidades prisionais, e o impacto do projeto nesses espaços e na sociedade. Ademais, quando acompanhei o grupo em uma intervenção, seus coordenadores me indicaram que começasse pela $\mathrm{PFB}$, porque ali já tinham uma boa inserção e seria mais fácil a minha entrada.

A partir de 2010, o projeto ampliou seu raio de circulação pelos estabelecimentos prisionais paulistas. A forma adotada é uma estratégia interessante no sentido de disseminar a iniciativa ao maior número de pessoas presas possíveis. Por outro lado, a expansão pode impactar a potência do projeto, trazendo riscos ligados à sistematização das práticas, descentralização das atividades para mediadores recém-formados e instabilidade em relação à continuidade do apoio público e ao futuro do projeto.

Além das considerações apresentadas acima, não tenho elementos para mensurar as consequências dessa nova configuração do projeto, tampouco o impacto dele nas dinâmicas prisionais em que esteve envolvido. De qualquer maneira, o apoio do poder público a uma iniciativa como esta representa a diversificação no direcionamento dos recursos da cultura, e o reconhecimento público da importância de um projeto cultural em âmbito prisional.

Os capitais econômico (recursos), cultural (livros, filmes), simbólico (experiência na prisão) e social (reconhecimento) que o grupo parece acumular são cartas importantes no jogo da prisão. Cartas que podem contribuir para a continuidade e sucesso dessa ação de reintegração social no cárcere.

${ }^{204} \mathrm{Na}$ FESPSP com projeto piloto na Penitenciária Feminina de Franco da Rocha. 


\section{7. “TV Cela"- Associação Cultural Votorantim}

\section{Apresentação}

A partir da pesquisa exploratória, tomei conhecimento de um projeto de rádio com as presas em Votorantim, interior do Estado de São Paulo. Ao entrar em contato com a jornalista Luciana Lopez, uma das responsáveis pelo projeto, ela me enviou o documentário "Povo marcado", dirigido por ela e por Werinton Kermes, que conta a história do programa de rádio de mesmo nome, que esteve no ar nos anos de 2007 e 2008.

No ano de 2009, os diretores do documentário e realizadores do projeto "Povo Marcado" começaram a produzir um programa de televisão chamado "TV Cela", também na Cadeia Pública Feminina de Votorantim.

O documentário "Povo Marcado" foi utilizado como fonte secundária de pesquisa. Nele, aparecem relatos de diversas pessoas implicadas diretamente ou indiretamente com o projeto de rádio: presas e seus familiares, participantes convidados da sociedade civil e os próprios realizadores do projeto. Ainda que o programa "Povo Marcado" não seja objeto específico deste campo de pesquisa, reproduzo algumas falas de seus participantes. $\mathrm{O}$ projeto "TV Cela" guarda muitas proximidades com a proposta do "Povo Marcado", do qual seria uma "versão televisiva". Entre essas proximidades, destaco o fato de ambos serem promovidos pela mesma entidade, tendo os mesmos apoiadores e objetivos, e na mesma unidade prisional.

As principais bases de dados sobre os projetos foram o documentário e o vasto material disponível na internet, em formato de texto e vídeo ${ }^{205}$, especialmente nos sites http://povomarcado.blogspot.com/ e http://projetotvcela.blogspot.com/ ${ }^{206}$.

\section{a) Título do projeto}

TV Cela

b) Realizadores, idealizadores, parcerias e convênios

${ }^{205} \mathrm{O}$ trailer do projeto TV Cela está disponível na internet, assim como vídeos dos programas. http://www.youtube.com/watch?v=5mgObqSOoCw, acesso 12/11/11.

${ }^{206}$ Acesso 12/11/11. 
O secretário de cultura de Votorantim, Werinton Kermes, é o idealizador do projeto. O projeto é realizado pela Associação Cultural Votorantim e coordenado pelos jornalistas Luciana Lopez e Werinton Kermes, e tem o apoio do Instituto Imagem, Artes e Inclusão Social, Delegacia Seccional de Sorocaba, Faculdades de Comunicação da Ceunsp, TV Votorantim, Salão Marcelo Soares e da ACESP (Associação dos Canais Comunitários do Estado de São Paulo). A iniciativa conquistou o Selo Cultura Viva e foi finalista do Projeto Generosidade, da Editora Globo.

\section{c) Estabelecimento(s) prisional (is) onde se realiza}

Cadeia Pública Feminina de Votorantim, a 102 km da cidade São Paulo.

A Cadeia Pública Feminina de Votorantim foi construída originalmente para abrigar 48 homens. Tempos depois, sem nenhuma adaptação, passou a receber mulheres, e sua lotação chega a 205 presas. As condições, consideradas precárias, já motivaram diversas ações do Ministério Público e outros órgãos. Uma nova unidade prisional, com capacidade para mais de 700 mulheres, está sendo construída no município. Após as transferências, a Cadeia atual será desativada.

\section{Objetivos}

O TV Cela tem o objetivo de retratar e discutir a atual situação da vida em cárcere, e também assuntos de interesse geral e variedades: "O estímulo sempre foi muito claro e de mão dupla: os programas servem para desfazer preconceitos da sociedade sobre o universo da carceragem e, ao mesmo tempo, as detentas se descobrem capazes de habilidades até então desconhecidas: afinal, são elas que assinam roteiro, produção, apresentação e câmera" 207 .

\section{Público alvo, seleção dos participantes e número de pessoas envolvidas}

Existe uma rotatividade entre as integrantes da equipe do TV Cela. As mudanças na equipe do projeto ocorrem por dois motivos: involuntariamente, por conta de ocasionais liberdades e transferências; e voluntariamente, para buscar envolver um número maior de detentas.

\section{Metodologia ${ }^{208}$}

\footnotetext{
${ }^{207}$ http://projetotvcela.blogspot.com/, acesso 11/12/2011

208 http://projetotvcela.blogspot.com/, acesso 11/12/2011.
} 
Além das entrevistas, também foram realizadas oficinas de produção, captação de imagem e apresentação. Diversas tomadas de imagem foram realizadas pelas próprias presas (chamadas de reeducandas nos textos do projeto), mostrando o dia-a-dia na Cadeia de Votorantim.

Com duração de 25 minutos, cada programa tem um entrevistado. As presas são responsáveis pela escolha dos entrevistados, construção de pauta, produção e apresentação do programa. Na equipe principal atuam cinco mulheres, que se dividem nas tarefas. Porém, indiretamente, todas as interessadas podem participar, pois podem sugerir entrevistados, temas e perguntas, além de acompanhar as gravações. Quando acontecem transferências, outras mulheres passam a integrar a equipe, e recebem as orientações necessárias dos coordenadores.

\section{Histórico e duração do projeto}

As gravações são realizadas desde outubro de 2009 em uma "cela-estúdio" improvisada dentro do cárcere. Cerca de 20 programas já foram gravados e editados.

Algumas edições já tinham sido exibidas por Canais Comunitários do Estado de São Paulo. Segundo os responsáveis, foi uma maneira de testar a audiência e aperfeiçoar as produções.

Em julho de 2011, o Programa TV Cela estreou na TV Votorantim - Canal 10 da Super Mídia.

\section{Povo Marcado}

O programa de rádio "Povo Marcado" foi produzido dentro da Cadeia Pública Feminina de Votorantim entre os anos de 2007 e 2008.

Com duração de uma hora semanal, o programa tinha o objetivo de oferecer aos ouvintes reflexões sobre o sistema carcerário brasileiro, além de música e informação. Buscava também levar o dia-a-dia da presa à comunidade, a partir de músicas e leitura de poesias feitas por elas. Contava ainda com entrevistas com médicos, artistas, autoridades e advogados. 
O programa "Povo Marcado" era apresentado pelas próprias detentas, a partir de uma celaestúdio no pátio da cadeia. A cada três meses, fazia-se o revezamento da apresentadora do programa. Antes de assumirem o microfone, as detentas recebiam orientação de jornalistas voluntários. Além disso, as outras presas podiam participar fazendo perguntas aos convidados.

O programa era veiculado todas as quartas-feiras, ao meio-dia, pela Rádio Nova Tropical FM de Votorantim, com reprises aos sábados. Era produzido pelas presas, com o apoio de uma equipe voluntária que colaborava com a estrutura técnica, fornecendo suporte na parte de jornalismo e de produção. A jornalista Luciana Lopez coordenava a equipe externa de produção, responsável pelo contato com entrevistados e edição do material.

O projeto foi uma realização da Secretaria de Cultura de Votorantim e da Delegacia Central da Cidade. Segundo a delegada ${ }^{209}$ à época, o projeto era "uma oportunidade de trabalho, de distração, e das pessoas terem contato com o mundo carcerário".

\section{Documentário "Povo Marcado"}

O programa "Povo Marcado" gerou um documentário, de mesmo nome, dirigido pelos idealizadores do projeto, Luciana Lopez e Werinton Kermes. O media-metragem foi premiado em diversos festivais, incluindo o de Gramado.

No filme, são entrevistados diversos atores envolvidos com o projeto "Povo Marcado": presas, familiares, voluntários etc. Em seguida, reproduzo algumas falas tal como aparecem no documentário, de forma a ilustrar a percepção do projeto por alguns de seus atores:

- "Pra mim é muito forte, muito emocionante. Você não passa incólume por uma situação como essa. Não adianta você achar que você é ... por isso eu acho que o projeto é importante. Você tem que estar aqui.."

(Paulo Betti, ator entrevistado no programa)

${ }^{209}$ Documentário Povo Marcado (2008). 
- "O cotidiano aqui é muito parado, então, quando o projeto apareceu, foi uma maravilha, me deu uma nova esperança" (Presa participante do projeto).

- "O programa Povo Marcado ele surgiu como uma nova esperança, entendeu? Porque todas aqui pensam: tô esquecida. Mas a gente vê que ainda existe pessoas lá fora que se interessam pelo que nós, nós reeducandas, precisamos" (Presa, produtora do programa)

- "O que se consegue não é transformar detentas em radialistas, a intenção nem é essa; a intenção é que se faça um processo de inclusão através da comunicação" (Paulo Betti, ator entrevistado no programa)

- "Minha preocupação era que elas não utilizassem gírias e aquela linguagem comum no mundo carcerário. Mas depois fiquei mais tranquilas porque percebi que essa era uma preocupação delas porque elas sabem que o programa é ouvido por pessoas do Brasil todo, e não só por pessoas que vivem a mesma realidade que elas" (Luciana Lopez, jornalista e coordenadora do projeto)

a "É impressionante. É um impacto e um impacto positivo. Você dar voz às pessoas nessa situação e garantir que essa voz possa chegar a muitas pessoas, em uma comunicação direta e verdadeira" (Padre Júlio Lancelotti, entrevistado do programa).

- "Com programa de rádio a cadeia fica mais tranquila. Não existe nem a ideia de fuga porque elas tem com que se ocupar" (mãe de uma presa participante).

- "Se a rádio está no ar a cadeia está em paz. Agora se não tem radio, você nunca sabe o que vai acontecer" (sogra de uma presa participante).

- "A cada palavra de apoio que recebemos ficamos mais confiantes que existam pessoas em nossa sociedade que acreditam na remissão e ressocialização dos encarcerados" (presa participante do projeto). 
- "Sabe uma coisa que me impressionou? A repercussão do que a gente faz, lá no blog [projetotvcela.blogspot.com], e em cartas que recebemos. Tem do Brasil inteiro, principalmente depois de um programa que fizeram sobre a gente lá na ESPN" $^{\prime 210}$ (presa participante do projeto )

- "Acho muito interessante esse projeto porque é um contato com o pessoal que tá aqui preso, é uma forma de você se aproximar, estar próximo dessa realidade, entender essa realidade, e trazer um pouco de diversão, alegria... E o trabalho aqui dentro da cadeia é muito simbólico, porque, de repente, elas estão aqui presas e elas podem mandar suas mensagens para todos os lugares do Brasil" (Paulo Betti, ator entrevistado no programa).

- "Acredito que um programa como esse é um ato político que dignifica a vida e dá voz aos que estão calados" (Padre Júlio Lancelotti, entrevistado do programa).

\section{Algumas reflexões em relação ao projeto}

A rádio e a televisão são dois meios potentes para a comunicação cárcere-sociedade. De forma geral, os presos (assim como o restante da população brasileira), gastam horas do seus dia entre telejornais, novelas e jogos de futebol.

Além de espectadores, as pessoas encarceradas são objeto de muitas reportagens, filmes e representações acerca do crime e da realidade prisional. Segundo o relato de vários presos entrevistados, essas reproduções midiáticas são responsáveis por construir uma representação social negativa da prisão e da pessoa presa.

Por isso, a oportunidade de elaborarem e veicularem uma produção cultural própria vai na contramão do emprisionamento, que isola a voz das presas. A partir dos programas, elas tem a possibilidade de levar a temática prisional e seus questionamentos para a discussão social.

Ademais, o projeto parece constituir uma via de mão dupla entre sociedade e cárcere, na linha proposta pela reintegração social. Por um lado, pela entrada dos entrevistados

210 Reportagem "Corredor da liberdade", Revista Monet disponível no endereço http://revistamonet.globo.com/coluna/2010/07/14/corredor-da-liberdade/, acesso 12/11/11 
convidados e executores do projeto no cárcere e o contato desses com as presas; por outro lado, pela comunicação que se estabelece entre realizadoras do "TV Cela" e espectadores, que dão um feedback para as presas por meio de cartas.

O êxito e a estabilidade dois projetos levados a cabo na Cadeia Pública Feminina de Votorantim podem estar relacionados com o caráter local dos projetos. O projeto surgiu e manteve-se concentrado em um estabelecimento prisional especifico. Essa permanência certamente contribui para a construção de uma rede de relações locais, formada pelas presas, idealizadores, realizadores, apoiadores, poder público, administração prisional etc.

A projeção nacional do documentário contribuiu para a difusão do projeto "Povo Marcado", e a visibilidade alcançada pelo filme foi um grande trunfo para atrair apoiadores para o novo projeto, “TV Cela".

Com a posse desse capital social, somada à conjunção de uma série de vontades, o projeto segue em funcionamento. Por enquanto ainda em âmbito local, mas com potencial para expandir o diálogo entre cárcere e sociedade livre.

\subsection{A perspectiva de gênero nos projetos de reintegração social em São Paulo}

Não poderia finalizar esse capítulo sem antes realizar alguns comentários sobre as questões de gênero que transpassaram as intervenções da sociedade civil nos cárceres paulistas. Principalmente porque as quatro entidades apresentadas neste capítulo desenvolviam trabalhos com mulheres encarceradas. Entre elas, três ("Quem somos nós?", "Curso transdisciplinar de criminologia penitenciária e execução penal" e "TV Cela") se desenvolveram exclusivamente em unidades prisionais femininas.

No caso do campo paulista, ainda que o recorte de gênero não tenha sido um dos critérios de seleção de projetos, no final ele se constituiu como um marco importante da amostra selecionada.

Certamente, a discussão dos motivos e consequências da concentração dos projetos selecionados em cárceres femininos mereceria uma reflexão mais aprofundada, a partir de conceitos emprestados das teorias de gênero, e da eleição dessa perspectiva ainda na 
produção dos dados do campo. Tal tarefa demandaria tempo e alguns deslocamentos na análise realizada, que não teriam lugar na presente pesquisa. Logo, o que proponho é levantar algumas hipóteses que ajudem na interpretação dessa configuração, baseadas no meu olhar e nas falas de alguns dos meus interlocutores acerca da perspectiva de gênero no campo paulista.

Das informações que colhi no campo paulista nos marcos desta pesquisa, arriscaria ${ }^{211}$ afirmar que o número de ações desenvolvidas pela sociedade civil nas unidades prisionais femininas é proporcionalmente maior do que as intervenções nas prisões masculinas.

Ao menos, Lourdes, uma das entrevistadas ${ }^{212}$ para essa pesquisa, parece confirmar esse diagnóstico e dar algumas pistas sobre os motivos da concentração de projetos sociais nas unidades femininas:

"Tem mais projetos na feminina justamente por essa pretensão de proteção ao sexo, amparo à mulher, à mãe. E acharem que realmente é mais fácil de trabalhar. Elas tem mais possibilidades que os homens. O sistema feminino e masculino não se comprara, da mesma forma a postura e a conduta do preso masculino e feminino não se compara

É interessante porque é o extremo, elas tem muitas possibilidades, e são mais indisciplinadas, mais rebeldes, mais bocudas. Eles que tem menos oportunidades são mais disciplinados, porem são mais violentos. Ela é menos violenta e mais rebelde"

Lourdes é agente de segurança penitenciária (ASP) do Estado desde 1990, por oito anos trabalhou em unidades femininas da capital e atualmente está no setor de educação da PJPN (unidade masculina). A perspectiva de gênero aparece bem marcada em ambas experiências: nas unidades femininas ela trabalhava com presas e basicamente entre funcionárias mulheres, enquanto que na unidade masculina, ela é exceção em meio aos homens. Essas vivências fazem de Lourdes uma interlocutora importante em relação a perspectiva de gênero na prisão, portanto, recorrei à ela diversas vezes nesta reflexão.

\footnotetext{
${ }^{211}$ Para precisar essa informação seria necessário um estudo quantitativo do cruzamento dos números da população prisional masculina e feminina, com os números absolutos e relativos dos projetos desenvolvidos em cada um.

${ }^{212}$ Entrevista a ASP, PJPN, julho de 2010.
} 
Proponho, a partir de três hipóteses, compreender a predominância dos estabelecimentos prisionais femininos como espaço de atuação dos grupos paulistas analisados nesta pesquisa:

- o abandono pelo poder público e pelas famílias das mulheres encarceradas deixa um vazio que é, em parte, preenchido pelas ações da sociedade civil. Nesse sentido, quanto mais carente de atividades é o centro prisional, maior a possibilidade de abertura para as propostas de intervenção social;

- a localidade das penitenciárias femininas paulistas atrai os projetos sociais. A partir de 1997, com a politica estadual de interiorização dos presídios (), a maioria das penitenciárias masculinas está distante da capital e dos grandes centros, o que dificulta o acesso da sociedade civil a essas unidades. Por outro lado, ainda há diversas penitenciárias femininas na cidade de São Paulo, fator que contribui para a presença da sociedade nesses estabelecimentos;

- tendência da administração penitenciária de facilitar o acesso às unidades femininas. As mulheres são representadas no imaginário social como mais dóceis que os homens, com menor potencial de agressividade. No sistema prisional, elas estão em menor número e em estabelecimentos prisionais menores, o que ajuda a direção do estabelecimento a controlar as presas e a interação que ocorre no espaço prisional, garantindo certa segurança para a sociedade civil.

O esquecimento das mulheres encarceradas pelo poder público é um discurso comum, e facilmente diagnosticável na realidade. $\mathrm{O}$ mesmo abandono não se verifica em relação ao envolvimento da sociedade civil em estabelecimentos femininos.

De forma geral, nas unidades prisionais carentes de atividades institucionais (escola, trabalho, cursos), a direção e os internos receberam bem as iniciativas da sociedade civil. Essa debilidade, comum a quase todas às penitenciárias (especialmente as femininas), pode facilitar a entrada de entidades externas à prisão.

Essa impressão pode ser confirmada pela diferente receptividade que o projeto "Quem somos nós?" teve em duas penitenciárias femininas. No relato de uma das executoras do 
projeto $^{213}$, as presas na PFC, por terem mais trabalhos e cursos à disposição, eram mais seletivas em relação aos projetos da sociedade, e buscavam conhecer mais sobre a proposta do grupo antes de aceitar participar. Já na PFS, as presas tinham interesse imediato no trabalho, frente à carência de qualquer atividade que lhes ocupasse o tempo de cumprimento de pena.

O projeto "Leiturativa", ainda que não proponha um recorte específico de gênero tal como “Quem somos nós?”, concentrou grande parte de suas intervenções em estabelecimentos femininos. No seu início, entre 2004 e 2009, dos seis centros penitenciários que receberam o projeto, cinco eram femininos.

Patrícia, coordenadora do "Curso transdisciplinar de criminologia penitenciária e execução penal" e de um subgrupo do GDUCC, já realizou intervenções tanto em penitenciárias masculinas, quanto femininas. Quando questionada ${ }^{214}$ das diferenças na inserção da sociedade civil em um e outro tipo de estabelecimento, ela afirmou que :

"na feminina é mais fácil porque a instituição é mais aberta ao trabalho, é mais receptiva, porque não existe esse tipo de trabalho. Tanto é que quando terminamos as duas edições eles fotografaram, pra direção era uma coisa assim "somos uma unidade diferenciada porque aqui tem esse tipo de trabalho".

Para Lourdes, agente de segurança penitenciária, sob o ponto de vista institucional, é mais fácil realizar um trabalho de intervenção das unidades femininas:

“porque a administração do feminino é realizada $99 \%$ por mulheres, então a mulher tem outra mentalidade, ela possibilita mais trabalhos de reintegração, de reeducação, elas visam mais esse trabalho para o sentenciado, a sentenciada. Mesmo porque não existe a superpopulação como na masculina, é uma outra estrutura física que acaba possibilitando esses trabalhos serem colocados em prática".

Porém apesar da estrutura e do apoio da diretoria contribuírem para a realização de trabalhos com as presas, para Lourdes é mais difícil trabalhar com a população prisional feminina:

${ }^{213}$ Durante o curso de “Capacitação da Metodologia do Projeto Quem Somos Nós?”.
${ }^{214}$ Entrevista em maio de 2010. 
"a conduta da presa feminina é muito diferenciada da masculina. A feminina é muito mais indisciplinada, muito mais arrogante. Tem todos aqueles problemas femininos, de TPM... Acaba sendo mais difícil nesse sentido. Elas tem muito mais coisa, mais assistência, por ser do sexo frágil, mas no entanto elas acabam muito mais rebeldes do que os homens"

Para além das necessidades humanas básicas, as mulheres presas tem demandas específicas e urgentes que reclamam a intervenção social. Mesmo com o aumento crescente do encarceramento feminino, o número de presas e de estabelecimentos prisionais destinados às mulheres ainda é muito inferior aos relativos aos homens ${ }^{215}$. Cabe às unidades femininas adaptarem-se às regras e práticas gerais da execução penal, dirigidas a um público eminentemente masculino.

Patrícia narra o processo de escolha do centro penitenciário em que o grupo iria propor a intervenção, e a sensação das presas frente à disparidade no tratamento prisional das mulheres: "A gente buscou algumas coisas na internet e percebeu que quase não existe trabalho dentro das unidades prisionais femininas. Em Santana a gente ficou sabendo do trabalho do ITTC. As presas mesmas relatam que falta esse tipo de trabalho, de ir alguém conversar, mesmo em questão das oficinas de trabalho mesmo, falta trabalho, faltam pessoas para ver o que elas produzem... elas se sentem à sombra inclusive nesse aspecto, elas dizem que é questão de preconceito de gênero".

O tratamento penitenciário destinado às mulheres não atende às suas necessidades básicas. É comum encontrar, no campo prisional, penitenciárias femininas em locais anteriormente destinados a presos homens. Espaços que, além de velhos, não foram desenhados para receber mulheres. As presas sentem-se desamparadas tanto pelo Estado ${ }^{216}$ quanto pela própria família e a sociedade de forma geral.

Nesse sentido, as presas sofrem mais agudamente o processo de prisionização. É notável a diferença na forma dos familiares, e da sociedade, situarem o crime nas histórias do homem e da mulher. O estigma da "presa-delinquente" que recai sobre a encarcerada,

\footnotetext{
${ }^{215}$ No relatório do Sistema de Informações Penitenciárias (Infopen), atualizado em dezembro de 2009, o Depena constatou que apenas $6,6 \%$ das pessoas presas são do sexo feminino, um total de 31.401 mulheres dentre os mais de 500 mil de encarcerados.

${ }^{216}$ Uma das queixas frequentes das presas, e simbólica no sentido de ilustrar essa questão de gênero, é a falta de absorventes íntimos nos estabelecimentos prisionais femininos, que faz com que elas tenham que recorrer a artifícios que estão ao seu alcance (como miolo de pão) para cuidar de sua higiene pessoal.
} 
representa um triplo rompimento: com a ordem (lei), com a sociedade livre (prisão), e com as expectativas em torno do papel social destinado à mulher.

Essa diferença se reflete também na qualidade e quantidade dos cuidados despendidos pelos familiares de presos e presas. As visitas do homem preso, em sua maioria composta de mulheres (esposas, companheiras, namoradas, irmãs, e especialmente mães), formam filas no dia de visita em frente aos estabelecimentos masculinos. Muitas delas enfrentam longas viagens, se encarregam de enviar regularmente o "jumbo" ${ }^{217}$ e enfrentar qualquer sacrifico para aliviar o sofrimento do homem preso.

A recíproca não é verdadeira em relação às unidades femininas, onde grande parte das presas não recebe apoio externo. Muitas não recebem sequer visitas- foram esquecidas por todos os conhecidos e familiares. E, apesar de terem conquistado o direito à visita íntima, quando existentes, os espaços destinados no estabelecimento prisional ficam desocupados. Nesse caso, o direito deixa de ser exercido por falta de homens com quem mantenham uma relação estável, que não estejam presos e que se disponham a ir ao cárcere visitá-las.

As mulheres constituem uma minoria, geralmente isolada, no sistema prisional, em relação tanto ao contingente de pessoas presas, quanto às pessoas da administração penitenciária e funcionárias do sistema. Lourdes narra a precariedade da condição das ASPs no sistema penitenciário:

"Não temos plano de carreira, depende muito do Secretário, dos coordenadores, se ele é mais liberal dá mais oportunidade para mulheres; se não for liberal ele troca todas as mulheres e põe só homens"

No sentido inverso, uma observação do campo aponta para a presença maciça das mulheres como participantes da sociedade civil nos projetos pesquisados. Esse contraste foi apontado pelas executoras do projeto "Quem somos nós?" e do "Curso transdisciplinar de criminologia penitenciária e execução penal", e também identificado no GDUCC ${ }^{218}$ e em ao menos um grupo do campo catalão (FAS).

\footnotetext{
${ }^{217}$ Conjunto de produtos de higiene e gêneros alimentícios enviados pelos familiares aos encarcerados, de acordo com lista predefinida pelo estabelecimento prisional.

${ }^{218}$ Minha percepção geral é que há um número muito superior de mulheres realizando trabalhos voluntários, inclusive nas prisões, em relação ao de homens. Na minha experiência frente ao GDUCC, em todos os anos de projeto, a proporção de homens no grupo se manteve em aproximadamente $20 \%$ do total de participantes.
} 
Beristain chama a atenção para a importância da presença feminina no trabalho voluntário na prisão, fazendo referência ao mito da deusa mãe tratado por Mircea Eliade ${ }^{219}$ e à teoria arquetípica de Jung. A potência do feminino no cárcere estaria ligada a um modo de ação mais flexível, sensível e receptivo:

"A sensibilidade feminina capacita, de uma maneira especial, a mulher para atuar como bálsamo nas feridas de todas as pessoas presas e de seus familiares... Convém insistir que ao voluntariado feminino competem tarefas, em certos casos mais urgentes e mais peculiares- e, desde logo, mais profundas- que aos homens"

(Beristain, 2000: 38)

O ambiente de um presídio (ainda quando destinado às mulheres) é, via de regra, masculino, rígido, sem espaços para que as pessoas demonstrem suas emoções, expressem suas angústias e demonstrem afeto. O masculino está ligado à ação, segue um "caminho pra fora", enquanto o feminino está associado à fluidez, as emoções, e segue o "caminho para dentro".

Pela experiência de Lourdes, as unidades prisionais masculinas não permitem que as ASPs contribuam com sua sensibilidade para a dinâmica prisional:

"A diferença no trato com sentenciado na feminina e na masculina é tão grande que você também sofre, porque você também não consegue aceitar determinadas ações que o masculino tem, entendeu? (...) Você quer impor seu ponto de vista, ai falam que você é mãezona, boazinha (...) Mulher num presídio masculino sofre preconceito, porque primeiro eles te veem como sexo frágil, não como profissional, mas como mulher. A pretensão até que é te proteger mas acaba te excluindo e te discriminando"

Para a filosofia tradicional chinesa, é do equilíbrio entre as forças femininas (yin) com as masculinas (yang) (representado pelo diagrama do Taiji) que surge todo o movimento.

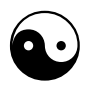

A necessidade de complementaridade entre os arquétipos feminino (anima) e masculino (animus) também é uma das preocupações centrais da psicologia analítica. Segundo Jung, o afloramento dos caracteres femininos em instituições tipicamente masculinas

\footnotetext{
${ }^{219}$ O autor aborda especificamente o tema da "Terra mãe" na obra Tratado de história das religiões, recém publicada no Brasil (2010), p. 193.
} 
seria a chave para o desenvolvimento de uma nova consciência institucional, passível de solucionar muitos dos problemas hoje enfrentados. Nesse sentido:

“O vasto campo do comércio, da política, da tecnologia, da ciência, enfim todo o reino do espírito utilitário aplicado ao homem é relegado à penumbra da consciência feminina; por seu lado, ela desenvolve uma consciência ampla das relações pessoais, cujas nuanças infinitas em geral escapam à perspicácia masculina."

(Jung, 2003: 82)

Dentro dessa ótica, conclui-se que a efetivação da dignidade humana em ambientes institucionais, por meio da valorização de relações pessoais e da preocupação com o outro, passa, necessariamente, pela redescoberta das potencialidades do feminino. Potencialidades estas identificadas na fala da ASP Lourdes, com a qual encerro essa breve reflexão:

"O mundo seria muito melhor se fosse administrado por mulheres, né? Porque nós temos muitas outras antenas para captar problemas e tentar soluções menos agressivas". 


\section{CAPÍTULO 8 \\ GDUCC: UMA PROPOSTA DE DIÁLOGO UNIVERSIDADE, CÁRCERE E COMUNIDADE}

Durante uma das reuniões do GDUCC em 2009, em um presídio paulista, estava em debate a motivação das pessoas para participarem do grupo. Um dos presos manifestou seu interesse em conhecer pessoas "diferentes", e perguntou se, caso ele um dia fosse até a Faculdade de Direito da USP, alguém do grupo poderia recebê-lo e acompanhá-lo em suas dependências. Mesmo informado de que o acesso à FDUSP era livre e público, ele insistiu na vontade de estar acompanhado.

Na mesma época, após sair de um encontro do GDUCC na FDUSP, eu estava na entrada principal da Faculdade ${ }^{220}$, conversando com um mestrando também coordenador do GDUCC e com uma aluna da graduação participante do grupo, quando se aproximou um senhor, aparentando estar embriagado, e me pediu dinheiro. Respondi a ele que dinheiro não tinha, e perguntei se poderia ajudá-lo de outra forma. Neste momento, ele começou a falar de suas dificuldades para se virar na rua (naquele momento ele estava morando na rua), visto que ele havia saído há pouco da prisão. A partir de então, a conversa se estendeu (para desespero da estudante que estava comigo, a qual parecia assustada).

Ele me contou um pouco de seus crimes -"havia matados muitos"- e de sua trajetória no sistema. Falou inclusive que ele fora um dos sobreviventes do Massacre do Carandiru em 2001, na Casa de Detenção de São Paulo. Depois de ouvir algumas de suas histórias, eu o convidei para participar das nossas reuniões do GDUCC, principalmente com o objetivo de ele contar sua história de vida e compartilhar com o grupo sua vivência no cárcere. Falei para ele que naquele momento estudávamos o cárcere a partir de um viés basicamente teórico, e que a contribuição de alguém que tivesse a experiência da prisão seria inestimável para o grupo. Ele logo se animou com a ideia, e marcamos que ele viria na próxima semana à Faculdade. Após um aperto de mãos, reforcei o combinado, e sugeri que entrássemos juntos na Faculdade para que lhe mostrasse o lugar das reuniões. Mesmo estando comigo e outro colega ao lado o "escoltando" e incentivando sua entrada, ele não

\footnotetext{
${ }^{220}$ Largo São Francisco, centro de São Paulo.
} 
conseguiu passar da porta, e tampouco foi à reunião da semana seguinte, ou a qualquer outra.

Esses dois acontecimentos guardam um simbolismo muito importante, e me lembraram imediatamente da parábola de Kafka, Diante da $L e i^{221}$. A Faculdade de Direito da USP, assim como a "Justiça", são instituições públicas em que, em tese, qualquer um pode "entrar". Porém, um abismo - ou infinitas portas - separa o homem comum da lei. O mito da racionalidade moderna é representado, no conto de Kafka, no primeiro pensamento da personagem, o homem do campo, ao se deparar com a justiça: "A Lei havia de ser acessivel a toda a gente e sempre" e, portanto, não poderia haver tantos empecilhos para adentrar no mundo da Justiça.

As dificuldades, porém são imensas. O direito, assim como os profissionais que o operam, guarda uma segura distância do homem comum. Da porta da lei não se vê a prisão. $O$ homem da lei não ouve o homem preso, a sociedade não se reconhece atrás dos muros. Mas é possível que caminhemos em outras direções. Esta tese retrata alguns desses caminhos.

\subsection{O significado especial desse capítulo: 0 fim e o início}

"nosso trabalho mais importante será o de comunicar esse conhecimentocomunicar nossos erros- para grupos políticos depois de nós" 222

(Mathiesen acerca do KROM, 1974: 119)

Finalizo a presente tese abordando minhas experiências e reflexões acerca do Grupo de Diálogo Universidade-Cárcere-Comunidade, hoje Projeto de Extensão da Faculdade de Direito da USP.

Como já exposto nos capítulos anteriores, foi meu envolvimento com o grupo desde sua fundação, em 2006, que motivou a realização de minha pesquisa e da presente tese. Reafirmando o caminho circular entre ação e reflexão, concluo a tese retomando o objeto

\footnotetext{
${ }^{221}$ Escrevi especificamente sobre esse tema no artigo Kafka: entre o brilho da justiça e a beleza dos acusados, publicado na Revista Liberdades, $\mathrm{n}^{\circ}$ 3, jan-abril, 2010, disponível no endereço http://www.revistaliberdades.org.br/site/outrasEdicoes/outrasEdicoesExibir.php?rcon_id=31.

${ }^{222}$ Tradução livre, no original: “... our most important job will be that of communicating this knowledgecommunicating our errors- to political groups after us"
} 
que a originou, com o intuito de analisar o projeto à luz de outras experiências de intervenção no cárcere.

Minha participação no GDUCC possibilitou um contato permanente com o espaço prisional, já que por mais de quatro anos realizei visitas semanais em estabelecimentos prisionais do Estado de São Paulo. Essa proximidade física com o cárcere foi essencial não só para o desenvolvimento da presente pesquisa, mas para que eu pudesse ler as teorias criminológicas à luz da realidade prisional sobre a qual atuava, em seu contexto específico. A partir daí, pude repensar os pressupostos que me guiavam, evitando construir um saber acerca da prisão sob uma perspectiva unicamente teórica, e distante da realidade intramuros.

Por outro lado, depois desses anos intervindo no cárcere, senti a necessidade de refletir sobre as práticas levadas a cabo pelo grupo. Para tanto, foi essencial meu distanciamento no período de 2010-2011 para realização do doutorado sanduíche. Principalmente porque, com o passar dos anos, o grupo foi crescendo, incorporando novas pessoas, diferentes formatos, outros discursos e "modos de fazer", muitos dos quais se distanciavam das minhas concepções pessoais e políticas acerca de um trabalho de intervenção no cárcere.

A proposta deste capítulo é apresentar o GDUCC e algumas das minhas experiências de aprendizagem na coordenação adjunta do grupo, a partir das quais destaquei alguns pontos de inflexão importantes para a discussão sobre a intervenção de grupos de sociedade no cárcere.

A perspectiva que passo a apresentar é pessoal, e não representa institucionalmente o grupo. Existem tantas possibilidades de leituras e recortes sobre o GDUCC quanto pessoas que já passaram pelo projeto, e todas igualmente legítimas.

Como fonte documental de pesquisa, utilizarei textos e outros materiais institucionais. Tive acesso a uma série de "relatórios" escritos pelos alunos e textos dos presos acerca da experiência no grupo, os quais se mostraram essenciais para matizar minha visão a partir de outros olhares. 
Além desse rico material, aproveitarei das informações que produzi durante os anos de coordenação adjunta no GDUCC, registradas em seis pequenos cadernos de campo que contem relatos sobre os encontros, falas dos participantes, impressões pessoais, observações gerais acerca da prisão, entrevistas, detalhamento de reuniões de planejamento e avaliação etc.

Ademais, para esta pesquisa, entrevistei diversos atores envolvidos com o grupo, direta ou indiretamente: sete presos, três voluntários, três ASPs, um diretor de unidade prisional e um juiz de execução penal. As entrevistas, realizadas no primeiro semestre de 2010 e no segundo semestre de 2011, foram importantes para pensar a reintegração social sob a perspectiva das pessoas envolvidas, e algumas delas deram origem ao "jogo de cena" que apresento ao final do capítulo.

O GDUCC é uma proposta de diálogo entre dois segmentos sociais: sociedade civil, representada pela universidade, e as pessoas encarceradas; para me referir, de forma geral, a pessoas de um outro e outro coletivo, utilizarei as denominações "acadêmico" e "preso". A cada edição do projeto, é formado um ou mais grupos, compostos de participantes acadêmicos e presos, em cada uma das duas penitenciárias que o grupo atua. A eles denominarei "subgrupos".

A seguir, após uma apresentação do grupo e da elucidação de seus métodos e objetivos, proponho o debate acerca de algumas problemáticas em torno da intervenção da sociedade na prisão. Construo minha análise ciente dos lugares que ocupei e ocupo na dinâmica do grupo, a partir dos meus interesses e limitações.

\section{2. "Grupo de Diálogo Universidade-Cárcere-Comunidade" - USP: apresentação do projeto}

Para apresentação do GDUCC, utilizarei o Roteiro de Apresentação de Projetos, descrito e aplicado no capítulo anterior, para descrever as entidades paulistas. 


\title{
I. Apresentação
}

O GDUCC é um projeto de extensão da FDUSP. Propõe uma intervenção no cárcere a partir de discussões e propostas práticas em torno do conceito de reintegração social e de suas implicações no âmbito da execução penal.

A proposta do GDUCC é a de comprometimento da universidade com a temática prisional, por meio da combinação entre formação teórica e intervenções no cárcere. Com isso, espera-se que os "participantes tenham uma experiência sensível da realidade carcerária, possibilitando a formação de estudantes críticos e conscientes da realidade que os rodeia" 223

O diálogo com o cárcere tem como objetivo proporcionar ao encarcerado "experiências significativas de inclusão social, pelas quais ele se sinta realmente partícipe da sociedade e redescubra seus valores como cidadão e como pessoa" (Sá, Marx, p. 3), de forma que possa ser reduzido o impacto do emprisionamento sobre a pessoa do preso, no sentido da expressão "fazer do cárcere menos cárcere" (Baratta, 1990), que sintetiza a proposta de reintegração social:

\begin{abstract}
"tornar o cárcere menos cárcere é criar estratégias para que os internos ali presentes tenham condições de se manifestarem, dentro das limitações impostas (princípio de realidade), como pessoas, em sua individualidade, desejos, frustrações, angústias, aptidões, aspirações etc. Noutros termos, é criar estratégias para que os internos se sintam e se descubram pessoas participes da rede de relações sociais"
\end{abstract}

(Sá, 2010:126)

Apesar de ter, com o passar do tempo, incorporado outras leituras acerca da intervenção da sociedade no cárcere, minhas ideias acerca da reintegração social surgiram a partir da minha formação teórica e prática no GDUCC. Portanto, estão muito atreladas às concepções do grupo. As teorias que influenciaram minha concepção de reintegração social exposta no Capítulo 1 (especificamente no item 1.6., aonde proponho um “arcabouço teórico de uma proposta prática de reintegração social”) em grande parte correspondem às bases teóricas de ação do GDUCC, que passo a apresentar.

${ }^{223}$ GDUCC: perguntas e respostas. Material de divulgação do grupo, 2010. 


\section{a) Título do projeto}

Grupo de Diálogo Universidade-Cárcere-Comunidade (GDUCC)

\section{b) Realizadores, idealizadores, parcerias e convênios}

O grupo foi idealizado pelo Prof. Alvino Augusto de Sá com o apoio imediato do Prof. Sérgio Salomão Shecaira, ambos professores livre docentes do Departamento de Direito Penal, Criminologia e Medicina Forense da FDUSP. Em 2008 e 2009, a Profa. Ana Elisa Bechara, também livre docente na mesma instituição, participou como coordenadora do projeto.

O GDUCC tem como coordenador geral o Prof. Alvino Augusto de Sá. A equipe de coordenadores adjuntas é composta por pós-graduandos do mesmo Departamento, orientandos do professor-coordenador, e outros profissionais convidados pelo mesmo.

Desde o início, o Departamento de Direito Penal, Criminologia e Medicina Forense da FDUSP respaldou a iniciativa do projeto. Ainda em 2006, o Departamento reconheceu oficialmente o grupo e, em 2010, apoiou a oficialização do GDUCC como projeto de extensão da Universidade.

O grupo conta ainda com o apoio do Departamento de Reintegração Social da SAP, principalmente na figura do Dr. Mauro Rogério Bittencourt, além dos diretores dos estabelecimentos prisionais e do juiz de direito responsável pela Comarca de Execuções Criminais de Guarulhos, sem os quais a entrada no cárcere não seria possível.

Além disso, no ano de 2011, o Centro Acadêmico XI de Agosto (FDUSP) conseguiu, junto à USP, transporte coletivo para levar e trazer parte dos participantes da Faculdade de Direito às penitenciárias, duas tardes por semana.

Esses apoios institucionais foram os únicos recebidos pelo grupo. Em nenhuma de suas edições o GDUCC contou com apoio financeiro para sua execução, sequer para cobrir os custos do projeto. Até o momento, o grupo não conta com qualquer convênio ou parceria formal com o poder público. 


\section{c) Estabelecimento(s) prisional (is) onde se realiza}

Penitenciária José Parada Neto (2006-atualmente) e Penitenciária Desembargador Adriano Marrey (2010- atualmente), ambas de regime fechado, masculinas, e situadas em Guarulhos- SP.

\section{Objetivos}

O objetivo do grupo é possibilitar experiências de encontro entre a universidade, o cárcere e a comunidade, buscando restaurar o diálogo entre esses segmentos da sociedade, a partir de alguns pressupostos teóricos aplicados à execução penal, tais como: simetria nas relações, aceitação da ética do outro e busca da transdiciplinariedade.

"Busca estreitar as ligações entre a comunidade, a universidade e o cárcere, por meio de encontros baseados no diálogo tão sincero quanto possível. Acredita-se que, por esse caminho, todos podem fortalecer-se, uma vez que cresce a consciência do papel que cada um representa, bem como dos laços humanos que a todos unem,"224

\section{Público alvo, seleção dos participantes e número de pessoas envolvidas ${ }^{225}$}

"A cada semestre, o GDUCC conta com novos membros, renovando-se a cada edição. Embora seja aberto à participação do maior número de pessoas possível, a experiência tem mostrado que o trabalho traz melhores resultados com grupos de 30 a 40 pessoas: 15 a 20 acadêmicos e 15 a 20 internos.

Para participar, não é necessária qualquer formação específica; nota-se, aliás, que o grupo apenas ganha com a diversidade. No entanto, como as atividades desenvolvem-se dentro de unidades prisionais, requer-se que o participante tenha mais de 18 anos e não possua antecedentes criminais. Tratam-se, em verdade, de requisitos estabelecidos pelas autoridades do sistema prisional.

Sempre buscamos que a composição do GDUCC fosse a mais diversificada possível, abrangendo estudantes e profissionais de diversas áreas, favorecendo a perspectiva interdisciplinar. Porém, ainda que o grupo sempre conte com advogados formados e

${ }^{224}$ GDUCC: perguntas e respostas. Material de divulgação do grupo, 2010.
${ }^{225}$ GDUCC: perguntas e respostas. Material de divulgação do grupo, 2010. 
profissionais e estudantes de outras aéreas, estes sempre foram minoria na composição geral. Aproximadamente $80 \%$ dos participantes são alunos da graduação FDUSP, principalmente dos primeiros anos do Curso, e em geral muito curiosos e ainda não atrelados a estágios.

Em 2011, foi curioso notar a grande presença dos alunos de primeiro anos, ainda que somente a partir do segundo ano possam estar matriculados oficialmente no grupo e receber os créditos por participar da extensão.

Abordarei a seleção dos internos participantes do GDUCC em item destacado ao final deste capítulo. A discussão sobre a forma e os critérios de seleção dos presos merece um olhar mais aprofundado, à medida que revela nuances da configuração das relações de poder entre entidade promotora da intervenção, administração prisional e os presos.

\section{Metodologia ${ }^{226}$}

Inicialmente, são realizadas algumas reuniões preparatórias nas dependências da FDUSP, imprescindíveis para construir os objetivos do GDUCC e consolidar a base teórica a partir de leituras e discussões.

Paralelamente a essas reuniões, os coordenadores acordam, com a Direção da Penitenciária e o Departamento de Reintegração Social, a entrada e condições do grupo na unidade prisional.

Em trabalhos voluntários, é grande o risco de abandono por não haver uma sensação de compromisso com o sujeito ou com o projeto que se desenvolve. Era necessário, portanto, desenvolver certo grau de comprometimento dos participantes, de modo a evitar a evasão.

Desse modo, criou-se uma dinâmica de coordenação em que, nos dias de visita à Penitenciária, havia sempre dois participantes do GDUCC coordenando as atividades, além de um outro, responsável por fazer as anotações de campo, que deveriam posteriormente ser transcritas e enviadas para todos os integrantes por e-mail. É bom salientar que as

${ }^{226}$ Fonte: Braga e Bretan (2008). 
participações como coordenador do dia e como 'sistematizador' foram voluntárias, sendo que alguns participaram mais de uma vez na mesma função.

Com isso, foi possível não só criar esse senso de responsabilidade, mas também possibilitou-se a apropriação do GDUCC pelos seus participantes, que permaneceram motivados durante todo o semestre, tendo havido pouquíssimas faltas e nenhum abandono.

$\mathrm{Na}$ Penitenciária, as reuniões se realizam em salas de aula da escola ou espaços educacionais (no caso de uma Penitenciária, em salas anexas à Biblioteca). Normalmente, para permitir que todos os participantes tenham possibilidade de falar, o grupo em cada Penitenciária é divido em dois subgrupos, que trabalham simultaneamente.

Após as visitas à Penitenciária, ocorre uma supervisão de aproximadamente uma hora, com a discussão dos problemas enfrentados, relatos do desenvolvimento das atividades e planejamento do encontro seguinte. O papel de supervisor cabe aos coordenadores do GDUCC.

Os deslocamentos até a Penitenciária, e desta de volta à FDUSP, são feitos em sistema de carona, com rateio das despesas entre os integrantes do Grupo. Esses momentos de deslocamento, em especial a volta, foram bastante valorizados pelos participantes da FDUSP, pela oportunidade de compartilhar impressões sobre o encontro no cárcere.

Os registros das atividades foram feitos apenas com a orientação de anotar as falas e todo o possível, inclusive observações sobre o ambiente, arquitetura, sensações causadas, agitação do local etc., mas sem uma orientação específica quanto à forma desses registros e sua posterior transcrição.

Cada um dos participantes dos trabalhos (presos, estudantes, coordenadores e funcionários) assinou um termo de comprometimento livre e esclarecido que autorizava a divulgação do trabalho, desde que assegurada a preservação da identidade dos participantes.

As atividades do GDUCC podem ser reunidas em dois blocos:

(i) bloco teórico, formado por uma seleção cuidadosa de textos, visando à reflexão crítica acerca da interface direito penal/criminologia, aplicável à realidade carcerária; 
(ii) bloco prático, marcado pelas visitas ao cárcere, e que possui um conjunto de atividades cujo objetivo principal é o de possibilitar experiência de interação social.

Nos encontros no cárcere, são realizadas dinâmicas de grupo, que servem como facilitadoras de uma aproximação entre os acadêmicos e os internos. $\mathrm{O}$ grupo observou que o caráter lúdico das dinâmicas serve para atenuar a pesada carga de julgamentos e identificações normalmente presentes em qualquer ambiente social, abrindo-se terreno para que seja possível, ao menos em alguma medida, tirar provisoriamente as máscaras e vivenciar um encontro verdadeiro com aquele que habitualmente se tende a julgar diferente, pela criação de um ambiente confortável e seguro.

\section{Histórico e duração do projeto}

O grupo foi criado no $2^{\circ}$ semestre de 2006 , e teve como cofundadoras e coordenadoras adjuntas eu e Maria Emília Nobre Bretan, à época mestrandas em criminologia orientadas pelo professor Alvino Augusto de Sá.

O nome GDUCC foi sugerido pelos participantes da primeira edição do projeto e representa a intenção de se constituir como um espaço de diálogo não só entre universitários e encarcerados, mas também com os egressos, as famílias e comunidades e, por fim, com a sociedade em sentido amplo, da qual, afinal, fazem parte todos esses segmentos sociais, já que o diálogo entre esses sujeitos foi rompido antes mesmo da cisão imposta pelos muros da prisão.

Apesar do grupo reconhecer a necessidade e importância de se fazer a ponte com a "comunidade", ou mesmo de fazer um trabalho específico com funcionários do sistema prisional, reconhecendo nossas limitações, optamos por realizar um trabalho direto somente com os presos.

Outros segmentos da comunidade foram atingidos imediatamente pelo projeto, conforme a fala ${ }^{227}$ de um dos presos participantes:

"Hoje teve uma movimentação porque houve uma divulgação do trabalho. Eu já compartilhei com a esposa, com meu companheiro de cela. Mexe, desperta interesse, vocês estão se aproximando de nós. As pessoas podem

${ }^{227}$ Caderno de campo GDUCC, PJPN, setembro de 2006. 
colocar a opinião do que acha”.

\section{Inserção no campo prisional}

O contato com o sistema prisional foi feito pelo professor-coordenador Alvino Augusto de Sá. A experiência de mais de trinta anos no sistema prisional, primeiro como psicólogo do sistema, depois como Assistente de Planejamento e Controle professor da EAP, possibilitou-lhe uma rede de contatos e a difusão de seu trabalho e ideias acerca da reintegração social.

A entrada, em 2006, na Penitenciária José Parada Neto (PJPN), aconteceu por sugestão da própria SAP.

No primeiro semestre de 2010, participei, juntamente com o professor Alvino Augusto de Sá e outros quatro coordenadores adjuntos, de um projeto piloto para ampliar nossas atividades para a Penitenciária Desembargador Adriano Marrey, com o apoio do juiz da VEC de Guarulhos, e após aparente estabilização das relações entre o Estado de São Paulo e o PCC. A partir de 2011 o grupo passou a realizar atividades nas duas Penitenciárias simultaneamente.

\section{Relação com o pessoal penitenciário}

Como já relatado anteriormente, a intervenção de pessoas de fora, de forma geral, não é bem recebida pelo pessoal penitenciário que, para garantir a realização da atividade, tem que deslocar a si e aos presos pelo ambiente prisional, além de preocupar-se com a segurança dos visitantes.

Desde o início, uma das preocupações dos coordenadores do GDUCC foi o contato com o pessoal penitenciário. A cada edição do projeto, antes do início das atividades com os presos, o grupo se reúne com a direção e ASPs, afim de que eles se inteirassem das atividades e da proposta do projeto. Esse cuidado foi essencial para, como na fala de um ASP: "vocês terem liberdade, o diálogo com a gente é importante".

O suporte de um funcionário penitenciário que faça a comunicação e os arranjos entre a entidade e o estabelecimento prisional é importantíssimo para garantir a regularidade do trabalho. Conforme retratei no Capítulo 6 , o bom relacionamento com os funcionários do 
sistema era uma das preocupações do Teatrodentro, que contribuía para o desenvolvimento do projeto em uma prisão da Catalunha.

Falhas na comunicação entre os coordenadores do projeto e a prisão podem trazer alguns inconvenientes na intervenção da sociedade civil. Um dos inconvenientes mais comuns, e que acarreta frustrações em todos os envolvidos com o projeto, é o grupo se deslocar até o centro penitenciário e não poder entrar. O impedimento de entrada das entidades pode ter origem em alguns fatores como: uma data festiva da unidade não comunicada à entidade; revistas nos estabelecimentos, que ocorrem sempre de surpresa; ou ainda, a um "clima estranho" na penitenciária, detectado pelos funcionários.

Em grande parte dos casos, os participantes presos e os da sociedade civil não são informados do motivo do impedimento. Uma das acadêmicas do GDUCC entrevistada para essa pesquisa ${ }^{228}$ detectou a dificuldade de entrada na PJPN como a principal dificuldade do grupo em 2010. O mesmo diagnóstico fez Patrícia, coordenadora do "Curso transdisciplinar de criminologia penitenciária e execução penal", sobre a intervenção do projeto no ano de 2009 na PFS, conforme descrito no capítulo anterior.

Buscando reduzir este tipo de infortúnio, antes do início de cada edição do projeto realizamos um encontro preparatório com os funcionários da Penitenciária aonde se desenvolverá o projeto. Normalmente, o encontro é realizado com a presença do Diretor da Penitenciária e alguns de seus "Diretores de Área" (normalmente de Segurança e de Trabalho e Educação), agentes de segurança penitenciária, e raramente, de alguns técnicos do sistema.

O objetivo dessa reunião é apresentar o projeto e seus participantes ao grupo de funcionários, e informá-los da presença do grupo nos próximos meses, buscando garantir não só a adesão ao trabalho e o seu andamento tranquilo, mas também, estimular o diálogo com os funcionários.

No início do grupo, imaginávamos ser possível integrar agentes de segurança penitenciária (ASP) nas atividades regulares do grupo. Com o passar dos anos, essa possibilidade se

\footnotetext{
${ }^{228}$ Entrevista realizada em dezembro de 2011.
} 
mostrou muito difícil de ser realizada, apesar de que, em cada uma das duas Penitenciárias em que atuamos, termos contado com o apoio e a participação indireta de um ASP, que pareceu ter uma sensibilidade diferente em relação às questões prisionais e esse tipo de projeto.

A dificuldade de integrar o ASP em projetos da sociedade tem origem em ao menos dois motivos. Primeiro, devido ao escasso número de funcionários: a Penitenciária alega não poder "tirar o ASP da tranca", ou seja, liberá-lo de sua função de vigiar e controlar o preso para realizar outro tipo de atividade. Segundo, porque há uma barreira entre os coletivos de presos e funcionários que não é fácil de ser transposta.

Uma ASP que esteve presente nos encontros da primeira edição do GDUCC, e que se destacou pela disponibilidade pessoal de participar das atividades do grupo, fala ${ }^{229}$ da resistência dos colegas em participar de um grupo com os presos:

"Hoje, graças a minha evolução, eu consigo entender eles. Mas vestir de ASP é uma proteção, assim como preso. Eu, pessoa, procurei ser justa e quebrar essa barreira. Ele te respeita muito mais quando se aproxima, do que com armadura".

Em entrevista ${ }^{230}$, outro ASP da mesma penitenciária falou que não poderia sentar em roda com o preso e ter um contato mais próximo, mostrar suas fraquezas, sob o risco de perder o respeito dos presos: "acho difícil fazer esse trabalho, porque uma distância deve ser mantida, pra garantir o respeito no pavilhão. Se fica muito perto, se expõe, fica difícil seguir com o trabalho"

Em conversas informais com alguns ASPs, ouvi por duas vezes a ideia de que colocar um ASP em pé de igualdade com um preso significaria rebaixar o ASP à condição de preso, o que seria inadmissível dentro da categoria. Um deles ${ }^{231}$ busca diferenciar os ASPs reafirmando uma pretenso atavismo lombrosiano na representação do homem preso: "Muitas pessoas que não trabalham no sistema carcerário consideram aqui um zoológico, mas o homem preso é mais selvagem que o normal".

\footnotetext{
${ }^{229}$ Caderno de campo, GDUCC, PJPN , 2006.

${ }^{230}$ Entrevista na PJPN, 14 julho de 2010.

${ }^{231}$ Caderno de campo GDUCC, PJPN, 2009.
} 


\section{Principais dificuldades}

Abaixo, elenco as principais dificuldades enfrentadas pelo grupo nesses cinco anos:

- deslocamento até as penitenciárias em Guarulhos. Muitas das edições não reúnem número de carros suficientes para acomodar todo o grupo da Universidade, o que causa transtornos nos encontros do grupo e faz com que parte do grupo se desloque de transporte público até as prisões;

- ausência de subsídios para custos do projeto. Os participantes e coordenadores, todos voluntários, tem que arcar com todos os gastos do projeto, desde o custo do deslocamento até a compra de materiais para as dinâmicas;

- manter certa uniformidade nas práticas e nos discursos do grupo, devido à diversidade de subgrupos em andamento sob a responsabilidade de diferentes coordenadores adjuntos. Essa dificuldade é acentuada pela falta de sistematização do histórico das ações de grupo.

- garantir o pleno funcionamento do projeto e o cumprimento das tarefas burocráticas e pragmáticas, sem perder de vista a perspectiva reflexiva sobre as práticas do grupo.

- Conseguir trabalhar com o perfil de preso indicado pelo grupo. Como relatarei adiante, a direção das penitenciárias, no processo de seleção dos presos participantes, não atende aos critérios indicados pelo GDUCC;

- imaturidade do grupo acadêmico. Apesar do GDUCC ser aberto a profissionais e acadêmicos de todas as idades, ele é basicamente composto de estudantes dos primeiros anos da graduação da FDUSP. A prevalência desse perfil foi acentuada a partir de 2009, com a difusão do projeto entre os referidos alunos e a formalização do grupo como projeto de extensão da universidade. Esta imaturidade transformou a relação entre coordenadores adjuntos e demais participantes, comprometendo a horizontalidade nas relações da academia, ao reatualizar a hierarquia dos papéis sociais do grupo, e causou ao menos dois reflexos no grupo: centralização das responsabilidades nas mãos dos coordenadores e passividade dos acadêmicos nas dinâmicas no cárcere e nas tarefas de execução geral do projeto. 
- realização de reuniões de supervisão de maneira regular e comprometida. No meu modo de ver, a supervisão é atividade essencial a qualquer projeto social, especialmente os situados em contextos tão complexos como a prisão, e envolvendo participantes tão jovens. As supervisões ocorrem geralmente após a volta da penitenciária (o que é cansativo, e as vezes não permite o comparecimento de todos do grupo), ou em substituição à ida à penitenciária (o que reduz consideravelmente o número de encontros entre acadêmicos e presos).

- suspensão das atividades do grupo nas férias e feriados. O calendário da universidade, e mesmo o social, não coincide com o da prisão. Na prisão, ainda que se comemorem as datas importantes e que sua dinâmica seja afetada com as visitas de fim de semana, não há feriado, nem se tira férias. Esses períodos ficam vazios de atividades nas unidades prisionais, e as atividades do GDUCC são suspensas. A suspensão dos trabalhos interrompe as relações que o grupo vinha travando na unidade prisional e é sentida com penar pelos presos envolvidos.

\section{Reflexos do trabalho e avaliação}

“Os resultados do GDUCC dificilmente podem ser mensurados de maneira objetiva. No entanto, o que se observa é que, nas unidades prisionais em que foi implementado, o interesse em manter e expandir as atividades nos semestres subsequentes é sempre manifestado por todos: presos, universitários, pessoas da comunidade e responsáveis pela unidade prisional" ${ }^{, 232}$.

Ao final de cada semestre, é pedido aos participantes que expressem suas impressões relativas às experiências vividas. É comum, conforme explanarei adiante, os presos representarem a experiência ressaltando a perspectiva relacional: a amizade, o convívio com gente da sociedade que os tratem com respeito.

Já os participantes acadêmicos enfatizam a possibilidade de conhecer a realidade carcerária e relacionar-se com os presos. De forma geral, a vivência no grupo impactou as preconcepções dos acadêmicos, que em sua maioria nunca haviam estado no cárcere. Ademais, esse impacto tem repercussão no âmbito familiar, acadêmico e profissional do

\footnotetext{
${ }^{232}$ GDUCC: perguntas e respostas. Material de divulgação do grupo, 2010.
} 
participante, contribuindo para a "normalização" dos presos, e para a aproximação desses segmentos da realidade prisional.

Nesse sentido, pode-se afirmar que o impacto do projeto ocorre imediatamente a nível individual, e a reverberação da intervenção nos indivíduos influi a médio prazo em parte do espaço prisional e na academia. De acordo com documento institucional do grupo:

"Em termos psicológicos, percebe-se que o GDUCC favorece que conteúdos humanos por tanto tempo projetados no outro sejam, pelo diálogo com este exato outro que antes se condenava, assumidos como próprios. (...) A partir daí, tem-se uma significativa melhora em termos de relações humanas: a experiência do GDUCC irradia seus efeitos para muito além do ambiente do grupo. Relacionamento e seres humanos são, afinal, a essência da vida",233

Nas entrevistas que realizei para esta pesquisa (com voluntários, presos, funcionários penitenciários, acadêmicos e um juiz da execução penal), diversos interlocutores compartilharam a necessidade de que ações do tipo do GDUCC acontecessem em maior quantidade e com mais frequência nos estabelecimentos prisionais.

Com o tempo, o trabalho do GDUCC foi ganhando reconhecimento e repercutindo em parte do meio acadêmico e prisional, dos quais passamos a receber uma série de solicitações para ampliação do projeto. Dentre elas, a ampliação do para a Penitenciária Desembargador Adriano Marrey (consolidada em 2011) e para os dois CDPs de Guarulhos.

Nos últimos anos, os coordenadores do grupo também tem sido procurados para ajudar na formação de outros grupos de intervenção, situados em outras universidades ou mesmo em outros estados da federação.

\subsection{A mobilidade dos participantes: o grupo em permanente construção}

O GDUCC é um grupo em construção. A cada edição do projeto, são revistos a metodologia de trabalho, os temas abordados e até os objetivos específicos do grupo. Um balanço dos cinco anos de história do grupo aponta para a perpetuidade do objetivo inicial

${ }^{233}$ GDUCC: perguntas e respostas. Material de divulgação do grupo, 2010 
do grupo (de estabelecer um diálogo com o cárcere) e da estrutura geral dos encontros. Porém, cada uma das dez edições do projeto assumiu um contorno específico.

Os temas e os formatos da interação social entre presos e acadêmicos no cárcere estão diretamente relacionados com as pessoas que compõem essa interação, e o contexto em que elas atuam.

Nesse sentido, os participantes utilizam-se de diversos tipos de capitais para a construção do projeto, cuja combinação vai produzir uma interação única em cada subgrupo. Proponho quatro exemplos para ilustrar a influência dos indivíduos na dinâmica que se criou no cárcere:

- em um subgrupo com uma psicóloga como coordenadora, é comum que as dinâmicas de grupo sejam melhor trabalhadas;

- em um subgrupo com presos e acadêmicos com grau mais alto de capacidade discursiva, as reuniões tendem a assumir níveis mais altos de elaboração;

- num subgrupo com músicos, os encontros eram finalizados com uma canção;

- ou ainda, o apoio do juiz da VEC impactou a recepção do projeto no cárcere e o envolvimento dos presos.

Cada participante tem uma influência fundamental na elaboração e execução do projeto. $\mathrm{O}$ tipo de intervenção proposta é impactado pelas constantes mudanças na composição do grupo, causadas pela alta rotatividade de acadêmicos e presos de uma edição para outra, e pela diversificação das pessoas na coordenação adjunta do projeto.

Para cada edição do GDUCC é formado um agrupamento específico de pessoas, composto por aproximadamente dois ou três coordenadores, vinte universitários, trinta presos e um agente de segurança penitenciária, intermediador da comunicação com o cárcere. As diversas possibilidades de interação social trazidas por cada um desses personagens, pela combinação entre eles e o cenário em que atuam, são determinantes na dinâmica que se estabelecerá nos encontros do grupo. 
Ainda que o diálogo com o cárcere seja o fio condutor de todas as edições do projeto, a maneira de materialização do diálogo varia de acordo com os participantes, e principalmente, com as propostas de condução das atividades. No formato atual do GDUCC, os coordenadores de cada subgrupo tem certa autonomia na elaboração das dinâmicas e temas dos encontros, e nas formas de interação social com os atores no cárcere.

Com o crescimento e reconhecimento dos grupo com o passar dos anos, mais pessoas passaram a trabalhar na coordenação das atividades. Em 2006, éramos duas coordenadoras adjuntas que formávamos dois subgrupos em uma penitenciária; em 2011, fomos nove coordenadores adjuntos, atuando em três subgrupos em duas penitenciárias, sob coordenação geral e importantíssima do professor Alvino Augusto de Sá.

Incorporar novos coordenadores, e adotar uma forma mais fluída e descentralizada, foram saídas para atender a crescente demanda em relação à ampliação do grupo. Apesar da adoção desse formato ter possibilitado o crescimento e fortalecimento do grupo nesses cinco anos, tal descentralização e personalização dos subgrupos pode afetar a harmonia entre discurso institucional e práticas, comprometendo a unidade e a potência do grupo.

Coordenar um subgrupo do GDUCC envolve inúmeras tarefas, tanto organizacionais como reflexivas. Os coordenadores são responsáveis por intermediar a comunicação com a burocracia prisional, reunir documentação, organizar caronas, atender aos alunos, conduzir as reuniões teóricas, preparar os encontros na prisão, etc. A realização dessas tarefas é essencial para garantir a execução do projeto, e portanto, ganha prioridade em relação a tarefas de cunho reflexivo.

Os coordenadores tem de enfrentar as contingências que se apresentam no dia-a-dia do trabalho. Muitas vezes, fazem isso sozinhos, por falta de espaço e tempo para respiros e reflexões no grupo de supervisão e troca. Nesse sentido, é essencial que o crescimento de um grupo, e a vontade de atender as demandas externas, sejam acompanhados de uma constante autorreflexão acerca dos objetivos e práticas do grupo.

Esse movimento circular de ação-reflexão ajuda a preservar a potência de um grupo, vinculando concepções teóricas com possibilidades de intervenções, elaboração discursiva 
com práticas, aproximando-se do que Mathiesen (1974) concebeu como "movimento inacabado" (the unfinished) e "experiência de aprendizagem" (learning experience).

Conceber a ação do GDUCC enquanto "movimento inacabado" possibilitou ao grupo testar diversas formas de fazer a intervenção no cárcere. A cada edição do projeto, a partir das avaliações dos participantes, feedbacks externos, novas leituras, junção de outros capitais humanos e transformações na conjuntura social em que atuávamos, repensávamos as nossas escolhas teóricas, e as práticas e discursos que sustentávamos no cárcere.

A prisão requer do agente a eleição de estratégias e posicionamentos no campo ${ }^{234}$. O fato do campo prisional ser estruturado e fechado não significa que sua estrutura seja imóvel, impermeável, insensível às ações dos indivíduos. Ao contrário, os discursos e práticas da prisão são alvo de constantes disputas entre os atores do campo. E quando grupos da sociedade intervém nesse espaço, eles se tornam atores dessa disputa.

As possibilidades de sucesso no "jogo da prisão" variam de acordo com as posições dos jogadores, as cartas (ou capital) que se tem em mãos, e a capacidade individual de internalizar o "sentido do jogo". Certamente, o conhecimento da prisão, de seus códigos, hierarquias e arranjos, ajuda o ator que ali intervém a compreender o campo e suas possibilidades.

As experiências acumuladas a cada edição do GDUCC, e o amadurecimento das relações do grupo com os presos e burocracia prisional, revertem-se em capital social e cultural valiosos na dinâmica na prisão, e em novas possibilidades de interação com o campo prisional.

Dessa maneira, o ato de situar o processo de transformações do grupo dentro da perspectiva de learning experience permite ao grupo que se transforme a partir das experiências, pessoas e contextos que se apresentam.

\footnotetext{
${ }^{234}$ A partir dos conceitos de "campo" e "jogo" de Bourdieu, explicitados no Capítulo 4.
} 


\subsection{Motivações dos participantes do projeto}

Apresentarei a seguir algumas das motivações declaradas por presos e acadêmicos para participarem do GDUCC. Inicio a exposição descrevendo uma dinâmica acerca do tema, proposta na PDAM em outubro de 2011. Em seguida, apresento as motivações dos presos, e a interpretação destes acerca da motivação dos acadêmicos para participar no projeto. Concluo com a perspectiva dos próprios acadêmicos acerca de suas motivações.

\subsubsection{Um retrato do GDUCC hoje: as motivações dos participantes de um subgrupo em 2011}

Em outubro de 2011, coordenando um encontro do GDUCC na Penitenciária Desembargador Adriano Marrey (PDAM) e explicitando meu interesse de pesquisa, propus aos presentes que expusessem o motivo de participarem do GDUCC. Tratava-se do segundo encontro do grupo, que contava aproximadamente com 21 alunos e 30 presos.

Analisando retrospectivamente, percebo que essa intervenção estava ligada a uma vontade de estabelecer um diálogo sincero no grupo, ${ }^{235} \mathrm{e}$ de trazer à tona algumas questões implícitas, que apareciam subentendidas em falas, mas que não eram discutidas abertamente nos encontros.

Minha intervenção foi uma reação a um episódio contado pelos outros coordenadores adjuntos na entrada da penitenciária. No primeiro encontro do grupo, em que eu não estava presente, um dos acadêmicos questionou (em "tom provocativo", segundo os coordenadores) aos presos se a participação no grupo lhes rendia benefícios penitenciários. Os coordenadores resolveram então "abafar" a intervenção do acadêmico, e seguir com as apresentações e eleição do nome do grupo, objetivo daquele primeiro encontro.

Ao tomar conhecimento do ocorrido, percebi uma oportunidade para propor que cada um expusesse as motivações que o levaram a participar do GDUCC. Essa proposta atendia a dois objetivos estratégicos para um grupo que se estava constituindo: ouvir as expectativas iniciais dos participantes e dar espaço para o conflito de ideias, incluindo aí até o tom provocativo do participante no debate.

\footnotetext{
${ }^{235}$ Conforme analisarei ao final deste capítulo, uma dos temas caros ao grupo é o equilíbrio entre o compreensão e enfrentamento no diálogo com os presos.
} 
Eu sabia que tanto os presos quanto os acadêmicos podem ter alguns ganhos bem concretos com o trabalho. Os presos são beneficiados porque a participação no GDUCC é um dado que lhes favorece nos pedidos de benefícios e progressões para o juiz, principalmente, aos olhos do atual magistrado (2011) da Vara de Execução Penal de Guarulhos, região das Penitenciárias em que o GDUCC atua. Para os acadêmicos, além da oportunidade de entrar em um estabelecimento prisional, a participação no GDUCC pode rendar créditos aos alunos da FDUSP, ou mesmo um incremento no currículo.

Nesse sentido, provoquei os participantes para que usassem o máximo de sinceridade, uma vez que os motivos mais utilitários ou egoístas são considerados menos nobres e tendem a ser ocultados. Exemplifiquei o que estava querendo dizer através da brincadeira, de fundo verídico, de que em uma outra edição do projeto havia o rumor que o principal chamativo do GDUCC era que o grupo "tinha um monte de menina bonita", dado ocultado por outras motivações, e só revelado a mim muito depois, por um preso com o qual tinha mais intimidade:

"Eu morava no raio três e tinha umas pessoas que tinha morado comigo e tinha participado. Eu perguntava e ele não sabia muito explicar, "É umas meninas bonitas que vem ai. Mas o que que fala, mas e ai? Qual a finalidade?" 236

Atendendo à minha própria provocação, abri a roda expondo que, para além da experiência de troca desinteressada e diálogo que pressupõe o GDUCC, eu mesma tinha um outro motivo para eu estar ali entre eles: estava colhendo dados pra minha tese.

Abaixo, passo a elencar as principais motivações expressadas por presos e acadêmicos durante a dinâmica. Ainda que esses dois coletivos tenham motivações em comum, optei por identificar a motivação com o tipo de participante, de forma a destacar as especificidades de cada um.

Cabe ressaltar que as motivações aqui expostas referem-se à percepção de um dos subgrupos do GDUCC, formado na PDAM no segundo semestre de 2011. Logo, qualquer generalização acerca dessas motivações fora desse contexto deve ser feita com cuidado.

${ }^{236}$ Entrevista a preso participantes, PJPN, julho de 2010. 
Grande parte das motivações dos acadêmicos e dos presos poderia ser agrupada dentro da ideia de "conhecer e trocar com o outro". Tanto de um lado como de outro, a curiosidade parece ter sido a principal motivação primária para participar do grupo. Como disse um dos presos, fazendo uso da linguagem jurídica: "em primeira instância, foi a curiosidade".

Foram reunidas sob essa ideia as seguintes manifestações de acadêmicos: "ir além da pena, conhecer a pessoa presa", "conhecer o preso e quebrar preconceito", "conhecer gente diferente com histórias diferentes"; e as seguintes fala dos presos: "ver pessoas novas, bonitas", "lidar com pessoas que tratam a gente com respeito", "conhecer além das etiquetas, pois ninguém nasceu no crime, ninguém vai morrer no crime, ninguém nasceu criminoso ou advogado".

A curiosidade em conhecer a prisão e a pessoa do preso apareceu associada à ideia de trocar com ele experiências e compartilhar vivências, sintetizada na motivação declarada por uma aluna de "conhecer o outro ser humano e trocar experiência".

Alguns acadêmicos destacaram o "lado humano" do grupo, representado aqui na ideia de duas participantes: "trocar, dividir e crescer" e "mostrar sensibilidade, humanidade". E outros poucos fizeram menção a objetivos de cunho mais político, como "reformar o sistema punitivo" ou "ajudar a abolir o sistema penal".

Alguns presos trouxeram concepções muito próximas da perspectiva da reintegração social, dentre as quais destaco as seguintes: "o GDUCC é uma ponte para mostrar o que está acontecendo aqui (na prisão)", ou ainda, "é uma “oportunidade de mostrar quem é a pessoa presa", "mostrar as ideias do preso". De forma geral, aos olhos dos presos, o convívio com os acadêmicos foi visto como uma "boa experiência", um "incentivo para o futuro".

Apenas três participantes acadêmicos expressaram interesses mais utilitários, como "queria entrar na prisão", "quero trabalhar com direito penal”, ou ainda, "preciso de material para escrever um livro, sou escritor". Somente um participante preso expressou esse tipo de interesse: "vai ajudar porque leciono na unidade". Em nenhuma das falas apareceram como motivos os créditos na universidade ou o aumento das possibilidades de ganhar benefícios. 


\subsubsection{Motivações dos presos}

Como forma de identificar algumas motivações para os presos participarem do projeto, selecionei algumas frases dos presos sobre o impacto do grupo e as reuni sob seis categorias: sair do mundo da cadeia; afetividade; entretenimento; encontro entre dois mundos; e outras possibilidades de interação social.

Da mesma forma que explicitei no Capítulo 6, na análise do campo catalão, as categorias que apresento aqui e no restante deste capítulo obedecem a um recorte específico do campo e das falas desses interlocutores, e portanto devem ser lidas dentro desse contexto.

Utilizei como fonte das falas aqui reproduzidas um dos encontros do projeto na PJPN em junho de 2007 (indicada em rodapé), que tinha como tema a motivação dos participantes, além de cinco entrevistas com presos participantes e duas entrevistas com presos nãoparticipantes realizadas em junho e julho de 2010 na PJPN. As frases que não possuem indicação da origem no rodapé tiveram como fonte as entrevistas com presos participantes. Para todas as demais, identifiquei a fonte.

Sair do mundo da cadeia

- "Sair daquele local, triste, rotineiro. Nosso dia-a-dia é a mesma situação"

- "Não tem como falar. Ali (no GDUCC) a gente conversa de tudo, levam você para fora do cotidiano" 237

- "Aqui parece que estamos mais na rua".

- "O trabalho (do GDUCC) é interessante tira a gente do mundo da cadeia. Começa a ter outra visão. Tira a gente da cadeia e leva lá pra fora”.

\section{Afetividade}

- "Era uma forma de expressar aquilo que sentia, de expressar lá fora minha realidade, ... sou muito tímido, mas muito sentimental"

- "De uma forma, vocês ficaram fazendo parte de uma pessoa, assim como eu de vocês. Agora vocês vão deixar a gente. É a parte mais ruim. Eu me apeguei muito a vocês. Tem muita coisa para aprender assim como vocês a aprender com a gente" 238

\footnotetext{
${ }^{237}$ Entrevista com preso participante, PJPN, junho de 2010.

${ }^{238}$ Caderno de campo GDUCC, PJPN, junho de 2007.
} 
- "Isso aqui é muito edificante, como o irmão estava falando até" (irmão no caso era um dos acadêmicos do GDUCC) ${ }^{239}$

- "Que a gente possa se encontrar na rua e acabar dando risadas do que a gente passou" 240

- "Eu imagino que seja um grupo de voluntários, como se fosse uma família, estudando, debatendo, né? Algo que a gente não saiba, que estão ensinando a gente, diversas coisas" 241

- “A cada reunião, é o tempo, é um diálogo, abre um espaço de ir se conhecendo um pouco mais" 242

\section{Entretenimento}

Como disse um ASP que entrevistei ${ }^{243}$ para esta pesquisa a respeito das atividades que se propõe no cárcere: "preso não gosta de coisa mórbida". Nesse sentido apareceu uma das motivações dos presos para frequentar o grupo:

- "Aqui é um clima gostoso, bate papo, até a cara muda",244

\section{Encontro entre dois mundos}

- "O projeto é um espaço para que a sociedade lá fora tenha uma visão diferenciada do cárcere. A curto prazo não tem retorno, a longo prazo esse projeto vai dar bons frutos. Portas estão abertas",245

- "Elo de ligação entre nós (presos) e sociedade, que há muito vem nos estigmatizando"

- "GDUCC é o momento que você se sente sociedade e a gente se sente cadeia"

- "As pessoas querem participar, vocês estão quebrando essa barreira do preconceito." 246

- dá expectativa pra gente que tá aqui dentro, bonito uma pessoa nova, às vezes da nossa idade, teve um caminho legal que a gente tinha vontade de ter e que não teve por vários motivos",247

Outras possibilidades de interação social

- "desligar o piloto automático para relacionar-se"

${ }^{239}$ Caderno de campo GDUCC, PJPN, junho de 2007.

${ }^{240}$ Caderno de campo GDUCC, PJPN, junho de 2007.

${ }^{241}$ Entrevista com preso não-participante, PJPN, julho de 2010.

${ }^{242}$ Caderno de campo GDUCC, PJPN, junho de 2007.

${ }^{243}$ Entrevista com um ASP, PDAM, outubro de 2011

${ }^{244}$ Caderno de campo GDUCC, PJPN, junho de 2007.

${ }^{245}$ Caderno de campo GDUCC, PDAM, maio de 2010.

${ }^{246}$ Caderno de campo GDUCC, PJPN, junho de 2007.

${ }^{247}$ Entrevista a preso participante, PJPN, junho de 2010. 
- "ter contato com as pessoas da sociedade, deixar de sentir excluso"

- "até para falar uma palavra tem que pensar, pra não falar gíria de cadeia"

- "vocês trazem o que esta acontecendo lá fora e nós aqui dentro"

- "O GDUCC fez muito bem pra mim, voltei a me relacionar com pessoas comuns. Aqui dentro você fica em um mundo fechado, isolado; eu resolvi esquecer o mundo lá fora e me fechei em mim. No primeiro dia do GDUCC, senti um impacto terrível, chorei na cela a noite toda. Mexeu comigo... eu achei que devia de estar do outro lado, como estudante universitário fazendo pesquisa". ${ }^{248}$

- "GDUCC é uma forma de estar se reintegrando à sociedade. Foram 12 anos só em contato com presos. Como vou expressar lá fora? Que palavras vou usar? Muitos não sabem como agir lá fora." O GDUCC fez com que eu abrisse minha mente, parecia um bicho do mato. Tinha vergonha de expressar com as palavras" 249

\subsubsection{A interpretação dos presos acerca da motivação dos acadêmicos para participar no projeto}

Nas entrevistas, uma das perguntas que fazia aos presos participantes, mencionada no roteiro de entrevista, era acerca da impressão deles acerca das motivações das pessoas da sociedade que vem ao cárcere. A motivação do voluntário parecia ser objeto de curiosidade para um dos entrevistados ${ }^{250}$ também: "Passou pela minha cabeça o que que leva, principalmente as moças, vir para um ambiente que só tem homem?"

Interessante observar, nas respostas reproduzidas abaixo ${ }^{251}$, as diferentes representações dos voluntários e das profissões jurídicas feitas pelos presos. Uma ideia recorrente nestas representações é a necessidade do profissional e estudante de direito conhecer o cárcere:

- "Pro estudante, ele está vendo na prática ali... Agora ver a fundo é difícil, né?"

- "É bem mais um trabalho de vocês da faculdade, né? Mas pra gente que tá aqui é legal ter oportunidade de falar, de saber o que tá pensando, o que tá acontecendo lá fora"

- "E alunos que estão estudando pra ser advogado, promotor, alguma coisa, e querem saber o que acontecesse no sistema penitenciário, o que leva um rapaz, um preso, a cometer crime, o que passa pela cabeça deles durante o cárcere, acho que é isso"

\footnotetext{
${ }^{248}$ Entrevista a preso participante, PJPN, junho de 2010.

${ }^{249}$ Entrevista a preso participante, PJPN, junho de 2010

${ }^{250}$ Entrevista com preso participante, PJPN, junho de 2011.

${ }^{251}$ Todas em entrevistas com os presos PJPN, junho e julho de 2011.
} 
- “É um trabalho legal, bom pra todo mundo. Tanto pra quem tá estudando, que aí vai defender melhor um caso, ou vai julgar melhor, condenar melhor, e pra gente aqui também"

- O juiz só conhece no papel, só quer julgar... Se vocês vêm aqui antes de se formar, vão pensar três vezes antes de condenar e julgar as pessoas, pois conhecem os homens, que são também pai de família, filhos...."

- "É muito estranho uma pessoa ter uma vida ali no mundinho dela, com a família dela do lado, uma família legal, a vida inteira, nunca ter tido problema nenhum tipo financeiro, de nada, num morar na periferia, sentar, estudar atrás de uma cadeira e julgar, condenar ou defender acho que é fácil.”

\subsubsection{Motivações dos acadêmicos}

Reuni quatro grupo de motivações dos acadêmicos para participar do GDUCC: conhecer a prisão e o preso; quebra de paradigmas; Identificação e pertencimento; e solidariedade com o preso.

Usei como fonte entrevistas que fiz com acadêmicos, e principalmente relatórios, parciais ou finais, produzidos pelos acadêmicos participantes (estes indicados em rodapé).

\section{Conhecer o cárcere e o preso}

- "uma das poucas oportunidades de conhecer o presídio",

- "entender a realidade do preso"

- "Os estudantes interessados olham com atenção as explicações e opiniões dos presos, reparando cada gesto e detalhe como se fosse o único. Alguns parecem ter uma curiosidade mórbida, outros sincera. Mesmo o tempo de GDUCC não afasta de algumas conversas um certo constrangimento, e veem-se braços cruzados e cadeiras mal ocupadas, quase que para ocupar somente o mínimo de espaço de confiança". ${ }^{252}$

\section{Quebra de paradigmas}

- Poder participar dessa troca, do convívio humano. Foi uma quebra de preconceitos e paradigmas muito pessoal" 253

- "É a ideia da reintegração. Das pessoas que visitam poder enxergar melhor o preso. Eu passo a aceitar um lado meu, posso viver com menos culpa, não ser iludido.

\footnotetext{
${ }^{252}$ Relatório de acadêmico participante GDUCC, PJPN, maio de 2011.

${ }^{253}$ Caderno de Campo, GDUCC, Parada Neto, novembro de 2009.
} 
Posso enxergar melhor minha humanidade, não ser levado pelo discurso do medo, fascista."

\section{Identificação e pertencimento}

Uma das motivações expressas pelos acadêmicos foi a de reconhecer a humanidade do outro. Para representá-la, reproduzo trecho de um relatório de um dos encontros ${ }^{254}$, em que os participantes discutiam moral e ética. O trecho descreve esse sentimento de identificação do acadêmico com o preso a partir da reação comum do grupo à fala de uma participante, concluída pela ideia de que "a única regra é não fazer para o outro o que não quer que façam para si mesmo":

- "O discurso da colega tocou cada um dos membros do GDUCC - presos ou não enquanto humanos, enquanto membros de uma mesma espécie e de um mesmo grupo que, por mais que separados por grades, muros e biografias, encontravam-se ali num mesmo contexto e que, por um instante que fosse, percebiam-se iguais não importando de onde vinham e para onde iam. Todos se sentiram dentro daquela pequena regra e que, exatamente por isso, protegia a todos da mesma forma. Daqui vieram os aplausos: não eram um elogio, mas um agradecimento" 255

\section{$\underline{\text { Solidariedade com o preso }}$}

- "Sempre tive vontade de defender aquele que é visto como mais fraco. Eu mesmo tive muita dificuldade de integração quando criança, na escola. Sempre tive problema de relacionamento Tentava defender o mais fraco porque me enxergava como o mais fraco". ${ }^{256}$

\subsection{Impactos do GDUCC: algumas percepções das pessoas envolvidas}

Ainda que o impacto do GDUCC nos participantes envolvidos seja difícil de ser quantificado, ele pode ser auferido a partir de dados qualitativos. Nesse sentido, algumas falas dos presos e acadêmicos a respeito do grupo podem dar algumas pistas do alcance da intervenção nos envolvidos.

Selecionei algumas falas dos presos e acadêmicos acerca do impacto do GDUCC, a partir de duas fontes:

${ }^{254}$ Relatório de acadêmico participante GDUCC, PJPN, maio de 2011.

${ }_{255}^{255}$ Relatório de acadêmico participante GDUCC, PJPN, maio de 2011.

${ }^{256}$ Entrevista com acadêmico participante GDUCC, PJPN, março de 2010. 
I. as avaliações do projeto pelos presos e acadêmicos, realizadas normalmente no penúltimo encontro na penitenciária e na reunião de encerramento na universidade;

II. as entrevistas realizadas para esta pesquisa, especificamente as respostas à seguinte pergunta do roteiro ${ }^{257}$ básico: "Você consegue notar alguma mudança nos participantes com esse trabalho?"

Com o fim de detectar alguns impactos da intervenção no estabelecimento penitenciário, inseri no roteiro de entrevista do diretor e funcionários do estabelecimento prisional a seguinte questão: "Você consegue notar algum impacto na prisão com esse trabalho?"

Reproduzo ao final algumas das falas de três agentes de segurança penitenciária (ASP) que ilustram alguns impactos do GDUCC no cárcere, a partir da perspectiva de funcionários ligados direta ou indiretamente com o projeto.

A seleção das falas dos presos, acadêmicos e ASPs atendeu a dois critérios:

o recorte de um contexto prisional específico. Selecionei somente falas cujos atores tivessem vivenciado a intervenção na Penitenciária José Parada Neto (PJPN), nas edições do projeto de 2007 a 2010.

que as falas fossem representativas do universo das percepções gerais do impacto do GDUCC.

A seguir, passo a narrar o impacto do GDUCC, a partir da visão dos presos, dos acadêmicos e dos ASPs, respectivamente.

\subsubsection{A perspectiva dos presos}

Reuni as falas acerca do impacto do GDUCC pela perspectiva dos presos, agrupando-as em torno de seis temas: contato com a sociedade e outras temáticas; acolhimento; esperança; relações humanas; mudar a percepção do acadêmico em relação ao preso e a prisão.

\footnotetext{
${ }^{257}$ Os roteiros de entrevista foram apresentados no Capítulo 4 desta tese.
} 


\section{Contato com a sociedade e com outras temáticas}

- "Pude lembrar do mundo lá fora",258

- "Eu queria para participar mais vezes. Estar falando melhor, em contato com a sociedade. Porque lá no pavilhão não é (sociedade). Estou privado dela" 259

- "A galeria da escola estava agitada, Porque vocês são visitas pra nós, é raro vir visita dentro de uma unidade, é raro a sociedade se preocupar com os nossos, em querer saber o que a gente pensa, como a gente vive. Isso (GDUCC) causa impacto", 260

- "Foi um aprendizado tanto de vida como educativo, abre os horizontes, abre o espaço"261

- "Lá fala de temas políticos, racismo tipo uma globalização"262

- GDUCC: vejo esse trabalho como desafio de gigantes. GDUCC é muito educativo. Eu mesmo aplico algumas das dinâmicas na minha família: Vamos geeducar agora minha filha" 263

\section{Acolhimento}

- “A gente viu que a gente não está tão desprezado como a gente via antes"264

- "O GDUCC foi um trabalho maravilhoso. Tiro o chapéu para vocês que vem da rua" 265

\section{Esperança}

- "O preso tem algo para se preocupar. Quando o preso causa um impacto total acaba entrando no mundo de vocês. Desejam quando sair ocupar o espaço que vocês ocupam. Aqui tem muitos jovens" ${ }^{266}$

- "Trouxe uma esperança para mim. Pelo GDUCC estou vendo que tenho uma esperança lá fora"267

- "Reintegração é uma oportunidade que as pessoas de fora do cárcere de mostrar que eu sou capaz de mudar",268

\footnotetext{
${ }^{258}$ Caderno de Campo GDUCC, PJPN, novembro de 2009

${ }^{259}$ Caderno de Campo GDUCC, PJPN, novembro de 2009.

${ }^{260}$ Caderno de Campo GDUCC, PJPN, novembro de 2006.

${ }^{261}$ Entrevista com preso participante, PJPN, junho de 2011.

${ }^{262}$ Entrevista com preso participante, PJPN, junho de 2011.

${ }^{263}$ Caderno de Campo GDUCC, PJPN setembro de 2009

${ }^{264}$ Caderno de Campo GDUCC, PJPN, junho de 2007.

${ }^{265}$ Caderno de Campo GDUCC, PJPN, novembro de 2009

${ }^{266}$ Entrevista a preso participante, PJPN, junho de 2010.

${ }^{267}$ Entrevista a preso participante, PJPN, junho de 2010

${ }^{268}$ Entrevista a preso participante, PJPN, junho de 2010.
} 
Relações humanas

- "teve muito uma troca humana. Nos grupos pequenos teve essa experiência. As pessoas poderem conversar sem pensar em divisões" 269

- "pessoal lá da faculdade gentil, simpático. Tô feliz de ter participado, triste por ter terminado" 270

- “O mais bonito do GDUCC é o lado humano, não é o projeto cientifico, o direito penal. O mais bonito é gente aprendendo com a gente, foi ter criado vínculos, amizades" 271

\section{Mudar a percepção do acadêmico em relação ao preso e à prisão}

- "todo mundo devia passar um dia na cadeia, preso. Como você vai julgar, defender

- acusar de uma coisa que você não vivencia?"272

- “a importância é pra pessoa conhecer o outro lado da sociedade",273

- "Vocês tem sido um instrumento que levam isso pra universidade"274

$\underline{\text { Reconhecimento da "humanidade" dos acadêmicos }}$

- "Imaginava que as pessoas que mexem na Justiça era tudo monstro" 275

- "Aprendi com vocês a ser humilde, porque vocês são humildes"276

- "Vocês me surpreenderam. Não demonstraram preconceito, tratava como ser humano (sic)"

\section{Abrir a casca}

Ainda que a ideia tenha aparecido de forma isolada na fala de um participante ${ }^{277}$, selecionei-a pelo forte conteúdo simbólico que ela carrega. Optei por reproduzi-la integralmente aqui, dentro do contexto da entrevista ${ }^{278}$, registrada com uso do gravador:

\footnotetext{
${ }^{269}$ Caderno de Campo GDUCC, PJPN, novembro de 2009.

${ }^{270}$ Caderno de Campo GDUCC, PJPN, novembro de 2009.

${ }^{271}$ Caderno de Campo, GDUCC, PJPN, novembro de 2009

${ }^{272}$ Entrevista a preso participante, PJPN, junho de 2010.

${ }^{273}$ Entrevista a preso não-participante, PJPN, julho de 2010.

${ }^{274}$ Caderno de Campo GDUCC, PJPN, outubro de 2008.

${ }^{275}$ Caderno de Campo GDUCC, PJPN, novembro de 2009

${ }^{276}$ Caderno de Campo GDUCC, PJPN novembro de 2009

${ }^{277}$ Que cumpre há 13 anos sua pena de prisão em regime fechado, participante de diversas edições do GDUCC na PJPN.

${ }^{278}$ Entrevista com preso participante, PJPN, junho de 2011
} 
"preso - (...) Foi uma meta de educação. É como uma mente fechada, e ai quando você quer abrir ela... É como um amendoim e uma casca, o amendoim está fechado, você tem que abrir ele, para ver se ele tá bom ali. Então naquele momento a mente avança..."

- Mas você acha que o GDUCC ajuda a abrir essa casca?

preso - Ele ajuda porque... Pô, eu tô parado dentro do pavilhão, pô não estou fazendo nada. De repente eu chego lá e começo a conversar com pessoas... Aqui dentro você tem um sistema, nem todos, mas tem uns que tem um certo sistema, pô o cara só quer falar de crime, da criminalidade, mas tem uns não, tem uns que tem a mente mais.., né? Eu mesmo sou essa pessoa, eu gosto de falar de literatura, de arte, gosto de falar de coisas que avançam, não gosto de ficar naquele progressinho, naquela coisa pequena, eu gosto de ver o horizonte crescer. Então por isso que eu vejo o GDUCC dessa forma, me ensinando a andar pra frente"

A meu ver, essa fala sintetiza a principal contribuição do GDUCC ao cárcere e à pessoa presa: abrir o horizonte prisional a partir da diversificação de atores e temas da interação social que ocorre na prisão. Essa ideia vai ao encontro das falas de outros presos citadas acima e agrupadas em torno da categoria "Contato com a sociedade e com outras temáticas".

Porém, além de identificar esse impacto do GDUCC na prisão e no preso, o referido preso narra seu processo de crescimento individual a partir desse impacto ("naquele momento a mente avança") com o grupo.

A experiência de diversificação da interação social promovida pelo GDUCC possibilitou ao preso "abrir a mente fechada", e entrar em contato com conteúdos pessoais que estavam protegidos por uma "casca".

Um dos objetivos da proposta de reintegração social levada a cabo pelo grupo é que seus participantes (tanto presos como acadêmicos) possa entrar em contato e expressar algumas dimensões de suas subjetividades que estavam escondidas, recalcadas, esquecidas.

Nesse sentido, identifico o processo pelo qual passou o preso, e principalmente, sua capacidade de elaboração e verbalização dessa experiência como sinais do êxito alcançado pela intervenção no cárcere. 


\subsubsection{A perspectiva dos acadêmicos}

Para ilustrar o impacto do GDUCC sob a perspectiva dos acadêmicos, selecionei algumas falas das duas últimas reuniões de avaliação do grupo que participei. Essas falas apontam para o impacto nas concepções dos acadêmicos e no círculo social:

- "A experiência do GDUCC mudou a experiência da faculdade de ver o preso como objeto, poder humanizar... A chance de ser uma pessoa mais justa. Não sei aonde vou trabalhar, mas vou levar isso comigo" 279

- "O GDUCC contribuiu para que eu tivesse mais contato com a realidade. Antes estava em um mundo fechado: casa - escola - shopping." 280

- "O mais louco do GDUCC é sentar com pessoas com discurso tão diferente do seu, e o diálogo ocorrer." 281

- 'Na verdade mesmo eu não sei o que aprendi. É fácil ler vários livros e colocar em uma prova. De alguma forma vai refletir, em uma conversa com meu pai- que é reacionário, com alguém que fala que sabe tudo do cárcere sem nunca ter pisado aqui". ${ }^{282}$

- "Voltei a minha cidade (no interior do Estado de São Paulo) e falei que toda quarta ia ao presídio. Ninguém vai ao presídio, não tem essa troca." 283

\subsubsection{Percepção dos ASPs quanto ao impacto na prisão}

Para elencar algumas percepções dos funcionários da prisão do impacto do GDUCC na PJPN, destaco algumas falas das entrevistas que fiz com três ASPs, nas quais fiz uso de gravador.

Os impactos percebidos pelos ASPs aproximam-se daqueles identificados pelos presos e outros participantes. Na fala de um dos funcionários da prisão, o GDUCC movimenta a prisão com gente e informação da rua:

- "esse tipo de serviço ajuda eles também. O dia que vai ter o GDUCC sempre tem aquela euforia, vontade de sair, escutar a palestra. A gente percebe neles, foge

\footnotetext{
${ }^{279}$ Caderno de Campo GDUCC, PJPN, novembro de 2009

${ }^{280}$ Caderno de Campo GDUCC, PJPN, novembro de 2009

${ }^{281}$ Caderno de Campo GDUCC, PJPN, novembro de 2008.

${ }^{282}$ Caderno de Campo GDUCC, PJPN, novembro de 2009

${ }^{283}$ Caderno de Campo GDUCC, PJPN, novembro de 2009
} 
daquela rotina...Por serem educadores da rua e trazer as novidades pra eles, eles gostam muito, você percebe",284

- "O que sinto é repercussão positiva. Todos que participam do GDUCC, se vocês permanecessem, por exemplo, todos os anos durante toda pena, eles estariam todo período participando do grupo com vocês" 285

Além disso, identificaram o grupo com uma experiência que incentiva a aprendizagem:

- "Quando vem incentiva as aulas. O pessoal de fora é um incentivo pra eles, quando vem, há uma reaproximação da sala de aula" 286

Um deles apontou um viés do tipo de preso que se interessa pelas atividades do grupo e as suas perspectivas:

- "Tudo que vem de fora é um aprendizado, tudo é instrução pra eles, tudo está ajudando na reeducação deles. Esses que se interessam em participar do grupo são pessoas que a gente percebe que realmente querem se reeducar, querem ter o convívio novamente na sociedade, eles se esforçam pra isso"

Uma ASP fez uma interessante apreciação do impacto do grupo:

- "Eu acho de grande importância você possibilitar um grupo de sentenciados pensar, ter contatos com pessoas da sociedade, que são os universitários, com a comunidade em si, e refletir. Se sentir assim... deixar de se sentir excluso, naquele momento ele se sente dessa forma. Já teve preso de falar pra mim: Dona, no GDUCC às vezes a gente até esquece que tá nessa situação, a gente volta a se sentir gente, pensa que é aluno, ou que é visita" 288

Nesta última fala, pode-se notar um alcance importante para qualquer ação que busca a reintegração social: despertar nos envolvidos o sentimento de pertencimento a um coletivo social maior. Um dos caminhos para a integração do cárcere com a sociedade livre é possibilitar que as pessoas encarceradas estabeleçam relações para além do papel social do preso, que não passem por um registro carcerário, mas se ocupe de dimensões humanas, educacionais e afetivas.

\footnotetext{
${ }^{284}$ Entrevista a ASP, PJPN, julho de 2010.

${ }^{285}$ Entrevista a ASP, PJPN, julho de 2010.

${ }^{286}$ Entrevista a ASP, PJPN, julho de 2010

${ }^{287}$ Entrevista a ASP, PJPN julho de 2010.

${ }^{288}$ Entrevista a ASP, PJPN julho de 2010.
} 


\subsubsection{Impacto do GDUCC em uma ASP participante: um breve relato}

As falas de agentes penitenciários acima apresentadas representam a perspectiva dos funcionários acerca do impacto do GDUCC nos presos e na prisão. Agora, para ilustrar o impacto que o grupo pode ter sobre um funcionário da cárcere, passo a expor um breve relato de Lourdes, uma ASP entrevistada ${ }^{289}$ para a presente pesquisa.

Cabe pontuar que Lourdes, da PJPN, assim como um outro ASP entrevistado na PDAM (que apresentarei em seguida no “jogo de cena”), são exceções no sistema penitenciário. Ambos foram peças chaves na comunicação do GDUCC com o estabelecimento prisional, e desde o início apoiaram o grupo em ambas as penitenciárias em que são realizadas as intervenções.

Inclusive, na história do grupo, Lourdes foi a única entre os funcionários penitenciários que participou diretamente dos encontros do projeto no cárcere. Entre os anos de 2006 e 2007, ela frequentou os encontros do grupo, realizando as atividades como todos os outros participantes, presos ou acadêmicos. Essa disponibilidade e coragem de querer se integrar no grupo, a despeito de todos os preconceitos, aponta para a sensibilidade diferenciada de Lourdes no tocante à temática prisional.

A seguir, reproduzo um trecho sem cortes de uma fala de Lourdes na entrevista, com o qual finalizo essa pequena amostra. Da leitura da experiência retratada pela ASP, destaco alguns pontos importantes a serem observados, quais sejam:

- o processo de transformação nas concepções pessoais acerca da pessoa presa. Lourdes passou de uma crença absoluta na presa à descrença total "Eu iniciei acreditando no ser humano, todas. Depois passei a pensar que nenhuma era inocente...".

- o impacto da experiência com o GDUCC nas suas percepção acerca dos preso;

- razões da dificuldade do ASP se incorporar aos encontros do grupo ${ }^{290}$ : "Ele acha que vai perder autoridade, que vai perder espaço para o sentenciado";

\footnotetext{
${ }^{289}$ Entrevista a ASP, PJPN julho de 2010.

${ }^{290}$ Temática problematizada no item VII, da apresentação do grupo "Relação com o pessoal penitenciário".
} 
- a ação dos mecanismos de defesa (no caso dela, conscientes) dos ASPs: "criei uma barreira pra conseguir trabalhar";

- reflexão sobre a atividade proposta no encontro e resultados alcançados: "Eu lembro que nessa dinâmica de um preso contando o histórico de vida dele, e os momentos de prisão dele, e o que ele estava sentindo naquele momento no GDUCC".

"Eu me emocionei muito nessa dinâmica...eu vou completar 20 anos de trabalho, mas às vezes sua rotina é.... Nós sabemos que o ser humano, cada um tem um motivo para cometer um delito... mas a gente nunca consegue se colocar no lugar daquela pessoa que errou.

Eu lembro que nessa dinâmica de um preso contando o histórico de vida dele, e os momentos de prisão dele, e o que ele estava sentindo naquele momento no GDUCC. Que conseguiu me comover a ponto de me transportar ao local dele, à pessoa dele, o que nunca tinha ocorrido na minha vida, por mais que eu tente ser profissional, nunca. Primeiro porque eu já criei uma barreira, eu criei uma barreira pra conseguir trabalhar, no meu começo de carreira - como todos- eu entrei pensando que o preso não quer nada com nada, que a agressividade corrige tudo, eu já fui assim, no período de Agente Penitenciário que trabalhei oito anos na chave com as mulheres. $\mathrm{Eu}$ iniciei acreditando no ser humano, todas. Depois passei a pensar que nenhuma era inocente...

...mas eu nunca havia me colocado na posição daquela pessoa, mesmo pra que eu não fosse o que os ASPs acham que eu sou: emotiva, mãezona... eu criei essa barreira e naquele momento o GDUCC derrubou essa barreira.

Da mesma forma que eu sempre via presos como preso eles também nunca tinham visto um funcionário como de uma outra forma, só aquela parede: é polícia. E naquele momento tanto eu consegui ver ele como pessoa ser humano, como ele me viu como pessoa, ser humano. Eu lembro que ele falou - eu nunca imaginei que a senhora, ou um agente ou funcionário pudesse ter essas atitudes, de sentar, conversar, de se abrir, de se expor na presença de outros sentenciados.

É difícil, sabe porque Ana? O ser humano tem medo de expor suas fragilidades, entendeu? Então assim, no momento em que você fica vulnerável... então acredito que o agente tem esse receio, eles não participam, devido a esse motivo, do preso passar a vê-lo de uma outra forma. Ele não pensa aqui vai me ver como ser humano, não. Ele acha que vai perder autoridade, que vai perder espaço para o sentenciado. Ele não vai ganhar um espaço como ser humano, ele acha que vai perder espaço como autoridade, isso acaba afastando o funcionário de participar desses eventos, ele não quer mostrar essa fragilidade, ele quer ser autoridade máxima, perfeito, ele quer estar na razão sempre" 


\subsection{Jogo de cena}

O êxito de qualquer projeto social depende da conjunção de uma série de vontades, circunstâncias e pessoas. A intervenção no cárcere pressupõe e envolve um conjunto de atores socais, que sozinhos e em relação, contribuem para a o êxito da intervenção. A narrativa da experiência desses atores sociais, a partir de suas trajetória de vida, pode contribuir para uma reflexão mais geral acerca das perspectivas de reintegração social.

Esse exercício, que denominei “jogo de cena"291, atende ao propósito de, a partir das entrevistas com alguns personagens, recriar uma cena de reintegração social. Essa proposta nasceu da vontade de situar as falas de alguns dos meus interlocutores dentro de suas histórias. E, portanto, de inverter momentaneamente a perspectiva da tese: priorizando a perspectiva dos atores sociais envolvidos no projeto, em detrimento de recortes temáticos da fala desses atores.

Com a finalidade de dar corpo à proposta do GDUCC, passo a apresentar um conjunto representativo dos personagens que possibilitaram a intervenção no cárcere, e de suas ideias a respeito da reintegração social e do GDUCC. O conjunto é composto por uma acadêmica, um preso, um ASP, o diretor do estabelecimento prisional e um juiz da execução penal.

Não pretendo, com as narrativas individuais, atingir uma síntese da diversidade das centenas de pessoas que já passaram pelo GDUCC. Ao contrário, imagino que cada um, a partir de sua vivência e de sua forma de estar no mundo, mereceria uma narrativa própria. Contudo, dada a magnitude dessa tarefa, optei por selecionar, para representar os diversos papéis sociais que compõe a cena da intervenção no cárcere, alguns personagens que julguei interessantes.

Tampouco elegi essas personagens enquanto representantes do discurso da categoria da qual fazem parte (preso, juiz, voluntário, etc.). Inclusive porque as pessoas selecionadas para figurar nessa cena são figuras ímpares, que, de forma geral, escapam ao padrão da categoria que representam.

\footnotetext{
${ }^{291}$ Inspirado na expressão “scène carcérale” empregada por Gilles Chantraine (2006: 278) e citada no Capítulo 1 desta tese.
} 
Perante uma amostra relativamente grande de pessoas que entrevistei, foi difícil a escolha dos personagens para compor esse exercício. Escolhi, dentre tantas possibilidades, seis pessoas para dar corpo à história do GDUCC, a partir dos seguintes critérios, temporizados

temporal: estabeleci que faria um retrato atual do grupo, portanto, daria preferência a pessoas que estavam participando de edições recentes (2010-2011) do projeto

grau de envolvimento com o projeto: dei preferência a participantes que estavam envolvidos com o projeto a mais de uma edição. Apesar da visão dos pouco envolvidos com o grupo (e até dos não-participantes) ser muito interessante, optei, nesse momento, por dar voz àqueles que tinham mais experiência no GDUCC, e portanto, que o tinham vivenciado em diferentes formatos e configurações. De forma geral, esses personagens tinham alguma elaboração conceitual da intervenção no cárcere, o que não significa que partiram de concepções próprias. Ao contrário, é interessante notar como algumas frases e ideias acerca da reintegração social são comuns a vários deles.

O fato de já conhecer os entrevistados, e ter com alguns deles contato semanal, ajudou na confiança e disponibilidade em relação a minha proposta de entrevista; por outro lado, a minha identificação nos papéis de coordenadora e pesquisadora certamente provocou um viés nas respostas dos meus interlocutores.

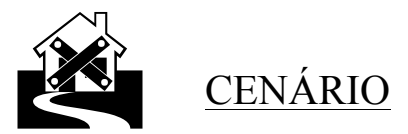

A ação de intervenção da sociedade no cárcere só pode ser compreendida dentro de determinado contexto social e político. Os acontecimentos no sistema prisional afetam a política criminal, e vice-versa. A entrada da sociedade no cárcere depende de uma conjunção política favorável: quanto mais equilibrado o gerenciamento do poder prisional entre presos e administração penitenciária, mais paz no sistema, e mais fácil o acesso ao cárcere.

Um desarranjo nesse sutil equilíbrio de poder desencadeia por um lado a violência estatal, e por outro, rebeliões, greves e outros movimentos dos presos, tais como os episódios que ocorreram especificamente em 2001 e 2006 no Estado São Paulo. 
A megarrebelião de 2001 foi um marco no sistema prisional paulista, principalmente porque até aquele momento as autoridades estatais negavam a existência do PCC nas penitenciárias do Estado, apesar da Comissão Parlamentar de Inquérito (CPI) do Sistema Prisional em 1996 apontar a existência do grupo.

Para fazer frente à eclosão explícita do PCC nas unidades prisionais, a partir de $2001 \mathrm{o}$ Estado resolve "fechar o sistema prisional", com interrupção maciça dos projetos sociais que estavam em curso nas unidades prisionais ${ }^{292}$. Segundo um ASP, um dos personagens desta cena: "aí, acabou com qualquer possibilidade de trabalho".

Hoje, dez anos depois dos acontecimentos de 2001 e quase seis dos ataques à cidade de São Paulo (2006), o sistema prisional paulista parece viver um período de estabilidade. Há alguns anos não se tem notícia de rebeliões no sistema. Nos últimos dez anos, as rebeliões haviam sido motivadas basicamente por transferências de líderes do PCC para regimes disciplinares rígidos ou para presídios situados fora do Estado de São Paulo ${ }^{293}$. Nesse caso, a mobilização do coletivo de presos nos estabelecimentos prisionais desafiou decisões tomadas no âmbito de política penitenciária, e coagiram o Estado a negociar seu poder com a facção.

A "bandeira branca" que parece estar hasteada nos territórios prisionais paulistas contribui para a entrada da sociedade civil no cárcere, por dois motivos:

- a intervenção da sociedade civil insere-se na lógica premial-punitiva, que rege a execução penal. A prisão permite a entrada da sociedade à medida em que julga seus internos merecedores dessa "oportunidade". Em um contexto de

\footnotetext{
${ }^{292}$ O documentário nacional "Entre a luz e a sombra" (2009) ilustra o impacto dos acontecimentos de 2001 na trajetória das personagens e dos projetos que estava envolvidas no cárcere. O filme focaliza o trabalho da atriz Sophia Bisilliat como voluntária social e idealizadora dos projetos "Teatro nos Presídios" e "Talentos Aprisionados" voltado para a descoberta de novos talentos artísticos no presídio. Entre os quais, a dupla de rap 509-E formada por Dexter e Afro-X dentro do Carandiru, que conseguiram "licenças especiais" para realizarem shows fora da penitenciária, autorizados pelo então juiz-corregedor dos presídios paulistas, Octávio de Barros Filho. As inovações do juiz quanto à autorização de saídas provocaram reações no judiciário que somadas aos acontecimentos de 2001, ocasionaram o fím do projeto e das esperanças dos envolvidos.
}

${ }^{293}$ Em junho de 2006 os presos de 40 unidades prisionais de São Paulo fizeram uma "rebelião branca": passaram a recusar-se a comparecer às audiências judiciais em solidariedade aos líderes do PCC que estavam em RDD em Presidente Bernardes e Presidente Venceslau. 
enfrentamento direto dos presos ao sistema, dificilmente a administração prisional premiará os presos com a participação em projetos da sociedade civil.

a administração prisional só permite a entrada de pessoas de fora no cárcere se puder ter o mínimo de controle sobre o espaço prisional, ou de confiança nas lideranças dos presos. Obviamente, a entrada de pessoas da sociedade civil será vetada se a direção dos estabelecimento identificar que elas correm riscos para além daqueles comuns ao espaço prisional. Isso não significa que o Estado e seus agentes tenham controle absoluto do espaço prisional, e portanto, que possam garantir a segurança do "visitante". Na minha experiência com o GDUCC, posso afirmar que quem garantiu o trabalho do grupo e a segurança dos participantes foram os próprios presos, especificamente lideranças da facção criminosa que atua no presídio.

Dado esse contexto político-social, nos primeiros quatro anos do GDUCC (2006 -2009), a intervenção ficou concentrada na Penitenciária José Parada Neto (PJPN), uma exceção no sistema prisional paulista por comportar presos que não se definem como pertencentes ao PCC, mas a outra facção criminosa rival (CRBC).

Avalio que a sugestão da referida unidade como espaço de inserção do GDUCC no sistema prisional se deu pelos seguintes fatores:

- melhor adequação da intervenção proposta ao formato da Penitenciária, em detrimento do CDP. As Penitenciárias são locais destinados a presos já sentenciados, e que, de forma geral e ao contrário dos CDPs, contam com uma razoável estrutura física, e com uma população penitenciária relativamente menor e mais estável.

- a unidade em questão possuía uma estrutura razoável para receber o grupo. O espaço educacional, composto de salas de aula e biblioteca, ficava fora dos raios, mais próximo dos setores da burocracia prisional e da saída da prisão. Essa conformação possibilitava que o grupo se reunisse em salas amplas, localizadas em uma zona com acesso limitado aos presos, e mais controlada pelos funcionários da prisão. 
- a localidade acessível da Penitenciária. No contexto da política de interiorização dos estabelecimentos prisionais da SAP (1997), as unidades de cumprimento de pena da Capital foram desativadas e substituídas por outras, em sua maioria no interior do Estado. Nesse contexto, as duas penitenciárias existentes no município vizinho de Guarulhos constituem opções viáveis para o deslocamento do grupo do centro de São Paulo até o centro prisional.

- a relação mais estável entre coletivo de presos e administração prisional. A PJPN é conhecida no sistema como uma unidade de presos que se denominam pertencentes da facção criminosa Comando Revolucionário Brasileiro da Criminalidade (CRBC), rival do PCC ${ }^{294}$. No segundo semestre de 2006, apenas três meses depois dos ataques da cidade de São Paulo em maio 2006, comandados pelo PCC, não era recomendável aos olhos do sistema inserir pessoas da sociedade civil nas penitenciárias sob domínio do PCC. Essa eleição não foi explicitamente verbalizada pela SAP ou pelo diretor da unidade prisional, mas desde o início, era comum ao grupo a percepção de que fazíamos o trabalho na PJPN, pois a vizinha Penitenciária Desembargador Adriano Marrey “era do PCC e não dava pra fazer o trabalho lá".

A PDAM é uma unidade prisional vizinha à PJPN em Guarulhos, composta por presos que se autodenominam integrantes do $\mathrm{PCC}^{295}$, e que foi uma das unidades paulistas destruídas na megarrebelião de 2001. Tem a capacidade de abrigar 1200 presos, e uma população prisional de mais de 2000 Já a PJPN conta com uma população prisional em menor número e é visivelmente menos superpovoada que sua vizinha, abriga aproximadamente 1100 presos para uma capacidade para 804 presos ${ }^{296}$.

No ano de 2010, o grupo foi convidado, pelo juiz da VEC e membros da administração prisional, a ampliar a intervenção a outro centro penitenciário. No primeiro semestre de

\footnotetext{
${ }^{294}$ Voltarei a discussão dessas configurações e seu impacto na intervenção no espaço prisional mais adiante, em item específico.

${ }^{295}$ Para compreender a distinção entre as duas unidades e suas respectivas facções, fundamental a leitura do artigo dos colegas Karina Biondi e Adalton Marques: Memória e historicidade em dois "comandos" prisionais (2010).

${ }^{296}$ Dados no site da SAP, atualizados em 22/07/2011. http://www.sap.sp.gov.br/common/unidades.html, acesso 30/11/2011.
} 
2010, o coordenador geral do GDUCC, juntamente com cinco membros mais experientes do grupo, iniciou um projeto piloto com cerca de dez presos na Penitenciária Desembargador Adriano Marrey (PDAM), possibilidade inviável no período pós- maio de 2006, contexto de início do grupo.

A partir do ano de 2010, o GDUCC passou a atuar concomitantemente nas duas penitenciárias de Guarulhos. Todos os personagens que aqui apresento, com exceção do preso participante, são comuns aos dois contextos:

- o diretor da unidade prisional, Dr. Daniel, estava em 2006 na direção da PJPN ${ }^{297}$, e desde 2010 dirige a PDAM;

- o agente de segurança penitenciária que conheci em um portão na PJPN, e hoje apoia o trabalho do grupo na PDAM;

- o juiz de execução penal da região de Guarulhos, responsável pela execução penal das duas penitenciárias;

- a acadêmica e a coordenadora, que também participaram de subgrupos em ambas unidades.<smiles></smiles>

\section{PERSONAGENS}

O contexto social e a entrada da sociedade civil no cárcere mobiliza uma série de atores sociais. A seguir apresento as cinco personagens que escolhi para ilustrar uma intervenção no cárcere, cujas biografias e percepções passarei a narrar em seguida. Os nomes aqui apresentados são ficcionais, para que fosse preservada a identidade das pessoas representadas.

○ Lia- Acadêmica

○ Jonatas- Preso

- Ivan- Agente de Segurança Penitenciária (ASP)

○ Dr. Daniel- diretor da prisão

\footnotetext{
${ }^{297}$ No segundo semestre de 2010, a equipe diretiva da PDAM foi inteira substituída sob acusação de envolvimento com esquemas de corrupção na unidade prisional. Para substituir os funcionários exonerados ou transferidos, a administração prisional designou o Dr. Daniel e sua equipe de confiança da PJPN .
} 
○ Dr. Ricardo- Juiz

\subsubsection{A acadêmica}

Lia é uma enfermeira, recém bacharelada em Direito por uma faculdade particular de São Paulo. Apesar dos seus 37 anos, Lia tem a compleição física de uma menina frágil; sua voz baixa e seus movimentos delicados revelam uma personalidade tranquila. Nos últimos três anos, ela integrou o GDUCC: em 2009 e 2010, fez parte de um dos subgrupos da Penitenciária Parada Neto, e, em 2011, no Adriano Marrey.

De forma geral, Lia diferenciava-se do perfil dos acadêmicos que compõem o GDUCC. Era uma das poucas do grupo que não era aluna da USP, além de ser mais velha, originária de uma família humilde, e com formação diferente da jurídica.

Ainda que o perfil de Lia não corresponda ao perfil geral dos acadêmicos, as concepções dela acerca da reintegração social e do GDUCC estão próximas das ideias de outros participantes, identificadas em outras entrevistas e nos relatórios dos encontros.

Lia foi escolhida para representar o papel de voluntária neste jogo de cena devido à sua longa história com o GDUCC, e a uma peculiaridade de sua biografia. As informações aqui apresentadas tiveram como fonte uma entrevista realizada e registrada em novembro de 2011, além das inúmeras conversas que tivemos em mais de quatro anos de convivência.

Ela ingressou no grupo em 2009, atendendo ao convite aberto que fiz aos alunos das minhas turmas de Processo Penal numa Faculdade particular da cidade de São Paulo. A atitude de Lia, uma aluna até então muito tímida, me surpreendeu. Era comum que eu fizesse convites aos alunos para participarem de projetos, seminários e cursos, mas poucos demonstravam interesse ou tinham disponibilidade de participar. No caso do GDUCC, Lia foi a única a integrar o projeto.

Quando perguntada qual a reação dos familiares e amigos em relação ao envolvimento dela com um projeto na prisão, Lia respondeu que 
"Houve, por parte de uma pessoa muito amada, um certo ciúme, era uma crítica constante ... o restante, mãe, irmão, tios ... nunca me criticaram, pelo contrário sempre me apoiaram em tudo com um certo receio, preocupação normal de eventual situação perigosa como o caso de uma rebelião. Já meus queridos amigos, me faziam todas as críticas possíveis e impossíveis. Para eles os presos tinham mais é que sofrer, considerando que eles não tinham piedade de suas vítimas. Eu sempre explicava para eles que o objetivo do projeto GDUCC não era inocentar o criminoso, mais sim estabelecer um diálogo para que eles fizessem uma reflexão"

A "pessoa muito amada" era o companheiro de Lia que tinha ciúme de seu bom relacionamento com os presos homens. Já os "queridos amigos" aos quais ela se refere eram seus colegas da faculdade, também meus alunos. Esses colegas, alguns funcionários do sistema de justiça (policiais, ASPs), defendiam o incremento na repressão criminal, na linha da "lei e ordem" ou "bandido bom é bandido morto".

Toda quarta à noite, quando Lia chagava à sala de aula após o encontro do GDUCC, seus colegas faziam piadinhas ironizando à crença dela no preso, e as ações dela no cárcere. $\mathrm{O}$ mesmo ocorria nas minhas aulas de processo penal, especificamente na classe de Lia, aonde, segundo ela, seus colegas faziam a seguinte apreciação a meu respeito: “A professora é legal, mas adora um noia ${ }^{298}$ ". Em uma aula em que eu falava sobre a excepcionalidade da prisão preventiva, ouvi ao fundo a provocação de um deles: "se gosta tanto de noia, adota e leva pra casa".

A resposta de Lia também comporta uma definição do objetivo do GDUCC: "o objetivo do projeto GDUCC, não era inocentar criminoso, mais sim estabelecer um diálogo para que eles fizessem uma reflexão".

A construção é interessante em dois sentidos:

- Primeiro, porque Lia situa a ação do grupo fora do binômio culpa-inocência, que só aparentemente cinde o dentro do fora do cárcere. Essa postura reafirma a proposta do GDUCC de interagir com o preso para além do registro da condenação pela justiça penal.

\footnotetext{
${ }^{298}$ Aqui noia foi utilizado no sentido de criminoso, viciado.
} 
- Depois, porque, apesar de Lia se remeter à proposta de diálogo, ela o dirige para os presos: "um diálogo para que eles fizessem uma reflexão". Essa concepção confronta com o discurso institucional do GDUCC, que defende o diálogo não como um instrumento de modificação do preso, mas para que desperte reflexões em todos os envolvidos. Esse tipo de construção sintática, que coloca o preso como objeto da ação, apareceu nas falas de outros acadêmicos do GDUCC.

Pelo discurso institucional do grupo, o GDUCC propõe uma "via de mão dupla" entre o preso e a academia, que não tem como objetivo a reforma moral do preso. Porém, nos discursos individuais dos participantes (e coordenadores), e também em algumas de nossas práticas, a perspectiva de reforma moral e o projeto de salvação do preso seguem presentes.

Essa tendência vem acompanhada por uma certa idealização dos acadêmicos em relação aos presos. Foi muito comum entre os acadêmicos a representação do preso como uma pessoa boa, cujo crime foi um desvio na sua trajetória ${ }^{299}$. Lia descreve como era "pacífica e prazerosa" sua relação com os presos:

"Com os presos tive uma ótima relação. Conversamos sobre tudo, me falavam de seus crimes, de suas famílias e dos amigos, sempre me respeitaram, um deles me deu um presente confeccionado por ele ( um vaso feito de papel) que eu guardo com muito carinho... Penso que se eles quando livres tivessem agido como agem lá na prisão, jamais teriam sido presos. Claro que estou falando dos que participaram do grupo.

As dificuldades de início era o transporte para ir até o presídio, depois a burocracia para entrar na prisão, acho que o mais difícil era ir até o presídio e não poder entrar. Com relação aos presos, não houve nenhuma dificuldade, a convivência era pacífica e prazerosa".

Segundo Lia, sua motivação para fazer parte do GDUCC foi conhecer a realidade carcerária para além do texto da lei:

"saber na prática como vivem os internos, como são tratados dentro da prisão e fora dela, uma vez que alguns são reincidentes. Saber como funciona um presídio, se a realidade condiz com o texto da lei”.

299 Tema que retomarei no próximo item. 
A curiosidade sobre o preso e sobre o cárcere foi uma das motivações mais recorrentes nos discursos dos acadêmicos, e mesmo na representação dos presos das motivações dos membros da sociedade civil, apresentadas anteriormente neste capítulo.

A descrição da "vida na prisão" é um tema recorrente nos encontros do GDUCC, que parece atrair tanto os participantes presos quanto os acadêmicos. Os presos, porque a informação sobre a dinâmica prisional constitui um importante capital social e simbólico na prisão.

A vivência do sistema é o trunfo dos presos na sua relação com os acadêmicos. Somente quem vivencia o dia-a-dia da prisão, a vida no pátio, os arranjos, acertos etc. tem legitimidade e informações para falar sobre a "vida na prisão". São os segredos da vida prisional, não visíveis ao olho nu do visitante, que os presos escondem e compartilham, em um jogo de confiança e reconhecimento.

No segundo semestre de $2009^{300}$, cansada do discurso vazio e repetitivo dos participantes acerca do GDUCC (incluído o meu próprio), sintetizado pela atrativa ideia de "que é um grupo de diálogo e troca, que tanto presos e acadêmicos tem coisas a ensinar e aprender", resolvi, em um encontro na PJPN, provocar o grupo, perguntando o que cada coletivo teria concretamente para ensinar.

Foi atribuído ao coletivo dos acadêmicos o domínio do saber jurídico, da linguagem formal e das "atualidades da rua". Aos presos, o conhecimento da vida do cárcere, do qual, segundo um preso, "os acadêmicos dependiam para escrever suas teses".

Além do aprendizado sobre o cárcere, a intervenção na prisão possibilita a interação com pessoas diferente em uma situação diferente. Na visão de Lia:

"é um meio pelo qual as pessoas podem interagir umas com as outras, vivendo situações diferente, ou seja, os presos com a sociedade fora do cárcere"

\footnotetext{
${ }^{300}$ Caderno de campo GDUCC, PJPN, 2009.
} 
Um fato da biografia de Lia é essencial para compreender o envolvimento dela com o GDUCC. Em 2003, ela trabalhava como enfermeira em um hospital, quando um bebê faleceu na maternidade. Na época, o caso teve ampla divulgação na mídia. Ela foi acusada de homicídio, e o processo se desenrolou até o final do ano de 2011, quando foi finalmente absolvida, após o próprio promotor de justiça requerer sua absolvição.

Lia conviveu oito anos com o fantasma do processo penal e a ameaça de punição. Segundo ela:

"foi um dano irreparável, pois foi um golpe profundo em minha vida, que me causou grande transtorno e de certa forma nunca será esquecido."

Ademais, Lia critica a precipitação da condenação social e penal para atender às demandas sociais:

"O Estado te pune, a sociedade te condena, sem procurar saber a verdade ou o verdadeiro culpado, para solucionar logo o caso e falar que cumpriu seu dever e se livrar do problema mais rápido".

O sentimento de impotência em relação à justiça e a dificuldade de provar a inocência fizeram com que Lia pensasse que, se ela fora acusada injustamente, outros também teriam tido o mesmo destino:

"Para quem cometeu o crime é difícil reparar, imagina quem não fez nada ser acusado injustamente, sofrer todo efeito de ser considerado um criminoso, sem ser."

A experiência de sofrer na pele as "mazelas do processo penal" impactou as concepções de Lia acerca do criminoso, e despertou seu interesse sobre a questão prisional:

"Todas as mazelas que enfrentei me fizeram mais forte, participar do GDUCC me ajudou muito, percebi que as injustiças existem até em proporção maior do que a justiça feita"

Ao final, Lia conclui que, ainda que tenha sido inicialmente motivada a participar do grupo para ajudar os presos, a interação social no cárcere desencadeou um processo de reflexão e transformação nela mesma: 
"A minha participação no GDUCC ajudou a resolver meus próprios conflitos, concluí que entrei com a intenção de ajudar, só que quem mais teve êxito e foi ajudada fui eu".

Após esses três anos convivendo com Lia, é notável a mudança de sua postura na interação social, e no cárcere em particular. Com o tempo, ela passou a ter mais facilidade para expressar suas ideias e se relacionar com o grupo na prisão, e inclusive, sua experiência com o projeto lhe rendeu certo status entre os acadêmicos mais novos do grupo.

De alguma forma, parece que a acadêmica saiu fortalecida da experiência. A reintegração social possibilitou que ela elaborasse e resinificasse sua relação com o sistema de justiça penal. Nesse sentido, algo se alcançou em termos de reintegração social.

\subsubsection{Preso}

Entrevistei Jonatas no primeiro semestre de 2010 na PJPN. Ele é o único das personagens que não transitou pelas duas penitenciárias que recebem o GDUCC. Até porque, em se tratando de unidades sob domínio de diferentes facções criminosas, o trânsito de uma para outra certamente significaria risco de morte para o preso.

Dentre diversos presos que entrevistei, selecionei seu relato porque ele participava dos encontros do GDUCC desde 2006 ("sempre que tiver vou estar participando"). O fato dele ter uma série de vivências com o grupo, e de nos conhecermos há quatro anos, foram fatores que contribuíram para que a entrevista fluísse muito bem.

Meu contato com Jonatas remonta a um episódio ocorrido ainda em 2006. Em um dos encontros, pelo qual os presos eram os responsáveis, eles propuseram uma dinâmica de troca de papeis: nós, da Universidade, simularíamos que éramos presos, e viveríamos algumas situações do cotidiano prisional produzidas por eles ${ }^{301}$. Fui escolhida pelos presos para representar o papel de Jonatas: em uma filipeta que me entregaram estava meu nome e o crime dele: art. 121 do Código Penal.

Nesse dia, viemos a saber que Jonatas estava preso por homicídio. Essa descoberta causou um desconforto no grupo dos acadêmicos, pelo fato de que, dentre todos do grupo, o

\footnotetext{
${ }^{301}$ Narro esse encontro em um capítulo de livro escrito em conjunto com Maria Emília Bretan. Ver Braga e Bretan (2008).
} 
último que nós apontaríamos como "homicida" seria Jonatan, um menino de 19 anos, doce, comunicativo, que andava pelo presídio com seu violão e gostava de fazer lual na praia.

Acho que esse foi meu primeiro aprendizado da experiência de reintegração social. Conclui que, se soubéssemos de antemão o ato criminal imputado a Jonatan, certamente teríamos outro olhar sobre ele e, talvez, um receio na interação social.

Jonatas define a reintegração social como:

"uma autoanálise, como eles (presos) vai agir na frente de vocês (universitários) e como vocês vão agir na frente de nós"

Confirmando a opinião de outros presos, para Jonatas, a principal motivação dos acadêmicos para realizar a intervenção no cárcere seria a oportunidade de ter um "estágio de aprendizagem" acerca da vida prisional:

"Hoje, podia estar em casa, vendo uma TV, escutando música. Mas o que esta acontecendo naquele lugar? Se ficar em casa nunca vai saber, é tipo um estágio de aprendizagem"

A possibilidade de comunicar dois mundos (cárcere e sociedade livre) e esquecer por alguns momentos a "vida da cadeia" parece ser o cerne da reintegração social para Jonatas:

"reintegração social é uma coisa legal. Esquece-se um pouco da vida na cadeia. Estamos interagindo no mundo deles, assim como eles estão no nosso mundo"

O que Jonatas menos gosta no GDUCC “é quando o grupo vai embora”. Para ele, uma edição do projeto possibilita pouco tempo de contato entre os participantes. O que ele mais gosta é do aprendizado, a amizade, "o jeito que vocês tratam a gente com igualdade, as brincadeiras, o entrosamento".

Ao final, quando perguntado "se você tivesse que propor uma ação da sociedade na prisão, o que você faria?", Jonatas trouxe uma contribuição muito importante para se pensar futuros projetos de reintegração social: 
"organizaria a cidade em grupos e perguntaria: O que você acha da pessoa presa? E todos deveriam vir conhecer a cadeia, pais de família, filhos, não só vocês do direito, um projeto global"

A sugestão dele se aproxima de alguns rumos já apontados por outros participantes, no sentido de diversificar o perfil das pessoas que participam da intervenção no cárcere para além dos estudantes de direito.

\subsubsection{Agente de Segurança Penitenciária (ASP)}

Ivan é agente de segurança penitenciária do Estado de São Paulo desde 1998. Conheci-o em 2007, quando ele trabalhava na Penitenciária José Parada Neto. Estava saindo com o grupo da referida penitenciária quando ele, então responsável pelo portão principal da unidade, começou a perguntar acerca do projeto, e contou de sua experiência anterior com o teatro do oprimido e com as técnicas de Augusto Boal.

Lembro de ter deixado a penitenciária compartilhando minha surpresa com os meus colegas da academia diante da figura daquele ASP. Após a rápida e inesperada conversa com Ivan, fiquei curiosa para saber mais sobre ele e suas ideias. Apesar de ter pego o contato dele naquela tarde de 2007, só voltaríamos a nos encontrar em 2010, já na Penitenciária Desembargador Adriano Marrey (PDAM).

Desde 2010, Ivan tem sido a ponte do GDUCC com a PDAM. É a partir dele que combinamos as atividades, acertamos o calendário e discutimos qualquer incidente na intervenção do grupo no cárcere.

Entrevistei Ivan, em uma manhã de outubro de 2011. A entrevista ocorreu nas dependências da PDAM, especificamente no setor da burocracia penitenciária. Após o final das quase três horas de conversa (não gravada), fui convidada por Ivan para almoçar com ele no refeitório da unidade. O almoço foi uma oportunidade única de interagir com outros funcionários daquele centro (muitos dos quais eu já conhecia), e de vivenciar um espaço de acesso restrito na prisão.

A biografia de Ivan, que passo a narrar, ajuda a compreender a sensibilidade deste funcionário para com a temática da reintegração social e os projetos sociais. Em 1998, ele era um empresário em falência, que foi atraído para prestar o concurso para ASP pela 
estabilidade da profissão pública e pelo bom salário (na época, segundo ele, equivalia a dez salários mínimos).

Já no primeiro ano de trabalho, Ivan empenhou-se para ir além do cumprimento ordinário da tarefa da segurança penitenciária. Em 2009, juntamente com outro ASP, e com o apoio da Prefeitura de Guarulhos, montou, dentro de um pavilhão da à época recém inaugurada PDAM, o curso de "Auxiliar de protético". Ivan, além de empresário tinha formação em protética, e pretendia passar essa experiência aos presos, além de prestar um serviço social, já que as próteses dentárias produzidas eram destinadas aos presos, funcionários e pessoas da comunidade de Guarulhos.

O curso funcionou bem por dois anos, até a megarrebelião de 2001, quando, segundo Ivan: "os presos ficaram isolados do mundo". Como represália à insurgência dos presos, todas os projetos sociais e atividades culturais que ocorriam na PDAM foram suspensas, e os presos da Comarca "ficaram anos sem benefícios".

Após a rebelião de 2001, na qual foi refém, Ivan passa a trabalhar em um Centro de Detenção Provisória (CDP) do Estado. Porém, após tomar conhecimento de que um preso acusado de estupro estaria sendo torturado pelos próprios ASPs, ele denunciou os colegas, que passaram a responder processo administrativo em virtude do incidente. Tal feito fez com que Ivan passasse a ser perseguido pelos colegas, o que lhe causou um grande sofrimento: "eu chorei pra caralho". Foi quando ele pressionou o diretor para que fosse transferido para o regime semiaberto na PJPN.

Era o ano de 2004, e Ivan "tava chapado", recebendo atendimento terapêutico, quando a psicóloga do sistema que o acompanhava o convidou para fazer parte de um grupo de teatro de funcionários. O grupo realizou oficinas acerca da técnica do teatro-fórum de Augusto Boal. "O que os funcionários esperam do sistema?” foi o tema proposto para o fórum-debate do grupo de ASPs.

Tratava-se de um projeto do Centro do Teatro do Oprimido (CTO- RJ), em conjunto com uma universidade inglesa e com a rede televisiva $B B C$. Juntamente com outros grupos de funcionários prisionais do Estado de São Paulo, o grupo apresentou sua peça "Alerta Geral" na Escola de Administração Penitenciária (EAP). A peça foi eleita a melhor peça do 
Estado; depois, em um concurso nacional promovido pelo Ministério da Justiça e chamado "Direitos Humanos em cena", o grupo de Ivan consagrou-se mais uma vez vencedor.

Com a saída de Nagashi Furokawa da Secretaria de Administração Penitenciária, o grupo não seguiu adiante: "quando Nagashi caiu, o teatro caiu". O então secretário de administração penitenciária era um dos grandes apoiadores da iniciativa teatral entre os funcionários penitenciários, e sua saída representou o fim de um espaço importante para os funcionários do sistema.

$\mathrm{Na}$ leitura de Ivan, com o teatro, os funcionários conquistaram a "abertura democrática de um espaço de discussão". A organização dos ASPs em torno do teatro-fórum possibilitou a reflexão da categoria acerca de seu papel na relação de forças na administração prisional. Segundo ele, "conseguiu-se passar para o funcionário que o diretor não tem tanta força, e para a SAP, que através da arte se poderia ter voz".

Dessa experiência, ficou uma matéria na grade de Direitos Humanos da Escola de Administração Penitenciária (EAP) que aborda a metodologia do teatro do oprimido. Mas para Ivan, desde o fim do projeto de teatro, "a voz do funcionário acabou, e com ela, a organização teatral-sindical dos funcionários".

Em 2007, Ivan é convidado para trabalhar com o Diretor geral da PJPN, junto ao Diretor do setor de Trabalho e Educação. Desta vez, não quis mais trabalhar "na chave", cuidando da disciplina dos presos, como ele mesmo diz: "vou querer ficar na chave, se posso estar envolvido em um trabalho dentro da unidade, colaborando?". A postura diferenciada de Ivan em relação às iniciativas na execução penal, e sua proximidade com os presos, fizeram com que ele fosse perseguido por colegas, mas respeitado pelos presos. Refém em três rebeliões, disse ter visto "muitos colegas tomando tapa na cara, eu não".

Depois de ter ficado três anos afastado por licença médica e envolvido em outros projetos, Ivan voltou para a PJPN em abril de 2010. No final do mesmo ano, juntamente com o diretor e outros funcionários de sua confiança, foi transferido para a PDAM.

Desde então, além de apoiar o GDUCC, participa de um grupo de teatro com presos, realizado no semiaberto da PJPN, que se apresentou em diversas universidades e 
instituições do Estado em 2010. O grupo contou com o apoio fundamental de Jorge Spínola, diretor de teatro com grande experiência em atividades nas prisões enquanto funcionário da FUNAP.

Atualmente, Ivan está elaborando um jornal, juntamente com os presos da PDAM, a partir de uma metodologia especifica, denominada "educomunicação". A ideia é que os encarcerados produzam um suplemento com notícias da penitenciária, a ser publicado no periódico Metro News ${ }^{302}$. Uma jornalista e editora do Metro News presta apoio voluntário ao projeto; ela se sensibilizou com a temática prisional após cobrir uma das apresentações do grupo de teatro de Ivan.

Para Ivan, além das parcerias mencionadas acima, o apoio do juiz da Vara de Execuções Criminais (VEC) de Guarulhos foi peça chave para a realização dos projetos, já que precisavam de um "padrinho" para endossar os pedidos à SAP. Esse padrinho acabou sendo o juiz, um dos personagens desse jogo de cena, e considerado um parceiro por Ivan.

Segundo o ASP, as atitudes inovadoras do referido juiz, como visitas periódicas à penitenciária, atendimento ao preso por vídeo conferência etc., tranquilizaram a população prisional, "que nunca tinha visto um juiz tão próximo da unidade".

Pela perspectiva do GDUCC, posso afirmar que Ivan tem um papel essencial na realização do projeto na penitenciária em que trabalha, já que ele é o elo que liga o grupo ao sistema. Por meio dele, acertamos o calendário, combinamos a composição do grupo, autorizações, e tratamos qualquer questão surgida durante os encontros. Ivan ainda diz ser o responsável por verificar o "clima da cadeia" para a nossa entrada: "chego mais cedo, vejo como a cadeia está, ver se o GDUCC pode entrar..."

Além disso, Ivan reclama a legitimidade do funcionário na elaboração dos saberes acerca do preso: "vou te falar uma coisa, quem sabe que técnica é melhor para o preso é o ASP". A partir desses conhecimentos, Ivan acaba assumindo a função de avaliador externo do impacto da intervenção do grupo na unidade. Na entrevista concedida, ele faz algumas

\footnotetext{
${ }^{302}$ Um jornal de grande circulação que é distribuído gratuitamente nos metros da cidade de São Paulo.
} 
críticas à imaturidade na forma de condução dos encontros do GDUCC na última edição do projeto. Para ele, houve alguns encontros em que os coordenadores não conseguiram envolver o encarcerado, que, na visão de Ivan, "quer falar, quer algo alegre, nada muito sério".

Como mencionado diversas vezes no decorrer desta tese, o bom relacionamento com o pessoal penitenciário é condição para o êxito de qualquer intervenção no cárcere. No caso da intervenção do GDUCC na PDAM, Ivan constitui uma peça importante, que atualmente contribui para a continuidade e aperfeiçoamento das ações do grupo.

\subsubsection{Diretor da prisão}

Dr. Daniel é um homem de presença forte. Com seu porte físico grande e seu tom de voz grave e rouco, dirige uma população de mais de 2000 presos na Penitenciária Desembargador Adriano Marrey (PDAM). Tem 32 anos de sistema, e, como ele relata, começou trabalhando "na chave", como ASP do sistema prisional paulista.

Ele acompanha desde o início o trabalho do GDUCC. Desde 2003, ele era o diretor geral da Penitenciária José Parada Neto, unidade em que o GDUCC começou sua intervenção. No final de 2010, ele assumiu a direção geral da PDAM, para onde grupo ampliou seus trabalhos.

Entrevistei Dr. Daniel em uma tarde de julho de 2010. A entrevista foi gravada, e ocorreu na sua sala, na PJPN. Dr. Daniel estava sentado em uma cadeira alta, diante de uma mesa situada bem no centro da pequena sala, enquanto as demais cadeiras do espaço eram baixas e fora do alcance da referida mesa. A configuração da sala da direção não permitia que eu, ou qualquer outra pessoa, permanecesse próxima, ou na altura do diretor, produzindo um duplo efeito: engrandecia a figura do diretor e criava uma barreira entre ele e seus interlocutores. Logo, apesar da disponibilidade do Dr. Daniel durante a entrevista, senti um estranhamento em ocupar aquele lugar demarcado. Sentia-me muito pequena frente à forte presença do diretor. 
Ainda que Daniel não possua título universitário, optei por denominá-lo “doutor”, seguindo a forma pela qual os diretores de estabelecimentos prisionais são chamados no sistema penitenciário.

O diretor parece ser figura respeitada no sistema. Ao longo dos anos, nunca ouvi palavras de presos ou funcionários que desabonassem sua conduta. Ademais, ele e sua equipe assumiram a PDAM com a incumbência de moralizar aquela unidade frente à revelação de esquemas de corrupção envolvendo o antigo diretor e muitos de seus ASPs.

Em nenhuma das duas penitenciárias o Dr. Daniel se envolveu diretamente com as atividades do GDUCC. Porém, ele sempre se mostrou aberto ao diálogo, e apoiou a entrada de pessoas de fora. Quando perguntado acerca das readequações na dinâmica da prisão por conta das pessoas que vem de fora, ele ressalta a função da direção de garantir a segurança da sociedade civil:

"A gente tem que dar garantia de segurança pra vocês. (...)Por um lado, tá certo, é um pouco perigoso? É um pouco perigoso. Mas a gente não pode ficar é perigoso, não vai fazer nada?"

Nesse sentido, a questão da segurança não pode inviabilizar a entrada da sociedade no cárcere, cujo formato deve ser acordado entre entidade e direção prisional:

"Você está interessada em fazer um trabalho, agora eu vou falar pra você não, não dá pra fazer por questão de segurança? Eu tenho que adequar, eu tenho que ver uma maneira que dê para fazer, e falar com você, vamos fazer desse jeito, daquele..."

Por esses e outros posicionamentos, Dr. Daniel pode ser considerado um diretor com "mentalidade aberta", sensível à temática da presença da sociedade no cárcere, e consciente da importância do papel dos funcionários penitenciários para as mudanças na execução penal:

"Eu procuro fazer com o pessoal que está comigo, um dois ou três que tem aqui (que daqui uns anos vão ser diretores também) que tenham essa mesma mentalidade. Que abra... não abrir a porta (risos), que desse oportunidade pras pessoas fazerem um trabalho no presídio, que façam, que traga outra mentalidade pro pessoal do presídio, que pessoal do presídio só pensa em fazer coisa errada, ai vai mudando, e influenciando outras pessoas, isso que é importante" 
Para o diretor, o apoio do Departamento de Reintegração Social da SAP para a ampliação dos projetos em sede de execução pessoal ainda é muito tímido:

"Por enquanto, tem a Secretaria da Reintegração, mas eles não mostraram, mas parecem estar querendo. Tem um pessoal bom trabalhando lá."

Ao ser perguntado acerca da reintegração social, Dr. Daniel associou-a à não-reincidência do preso:

"Muitas poucas pessoas saem daqui pensando em fazer as coisas corretamente. Nesse tempo que estou aqui, vi muito poucos que se reintegraram. Mas os outros você fica só sabendo pelo jornal, tentou assaltar tal lugar. Mas eu sempre acreditei (na reintegração). Tem que acreditar, se um diretor não acredita tem que largar tudo, se aposenta"

Logo, apesar de dizer acreditar na proposta de reintegração, ao concentrar a problemática da integração no esforço e mérito individual do preso, parece-me que ele estaria mais próximo das "ideologias res"303:

"Então pra gente, pra mim, o que interessa pra mim é que o preso esteja com a mente focada em evoluir, sair no presídio e não voltar mais, que o preso na rua tenha alguma meta, trabalhar estudar, fazer um coisa lícita".

Dr. Daniel destaca o impacto da entrada da sociedade civil, e algumas diferenças da PJPN em relação a outras unidades prisionais:

"É importante (a presença da sociedade civil). Tem unidade por aí que não vai ninguém. O preso se sente até excluído com esse tipo de coisa. De vez em quando a gente conversa com preso que vem de outro lado, que fala: pô, nas outras unidades não tem nada disso, não vai ninguém, a gente não tem contato com o mundo exterior, né? Com as pessoas, com estudiosos, tal, essas coisas. Aqui já é diferente, o pessoal se interessa, volta e meia, sempre tem alguém querendo fazer algum trabalho"

Uma dos temas que atravessa o GDUCC é o contexto prisional em que ocorre a intervenção. A PJPN e a PDAM, apesar da proximidade geográfica, apresentam configurações bem diferentes. A escolha da PJPN para receber o GDUCC, em 2006, não

\footnotetext{
${ }^{303}$ Reabilitação, ressocialização, reeducação... expostas no Capítulo 1.
} 
foi aleatória. Como relatei anteriormente, nesse período, o governo do Estado de São Paulo e o Primeiro Comando do Capital (PCC) protagonizavam um guerra, dentro e fora dos cárceres. E a PJPN era, e continua sendo, uma das poucas unidades do Estado em que o PCC não está presente.

Aos olhos institucionais, a PJPN parece ser uma unidade mais propícia para receber projetos da sociedade civil. Ao menos três outras características contribuem para isso: boa estrutura física, menor população prisional, composta por presos que "não dão problema" para a Coordenadoria Regional da SAP. De acordo com Dr. Daniel:

"Esse presídio tem menos presos que os outros. A gente procura fazer com que os presos que estão aqui não deem problema pra Coordenadoria. Mas é presídio, tem mil presos, mil cabeças diferentes..."

Segundo o Dr. Daniel, a continuidade das iniciativas dependem da confiança nos presos em aderir às atividades propostas pela instituição ou pela sociedade civil:

"A gente costuma conversar com o preso: você está abrindo a porta para os outros presos"

Dr. Daniel associa ainda a disciplina da cadeia com a celeridade de julgamentos de benefícios, fator que contribui para a redução da tensão no espaço prisional:

"com a cadeia disciplinada, ao invés do juiz ficar julgando problemas (faltas disciplinares) está julgando benefícios"

De forma geral, e desde a perspectiva de não enfrentamento da administração prisional, a PJPN pode ser considerada uma cadeia disciplinada. Inclusive, uma das acusações do PCC à facção rival CRBC (presente na PJPN) é que esses últimos "corriam junto com o sistema”, ou seja, que correspondiam às expectativas da direção prisional, não causando problemas e comprometendo-se com o projeto institucional da prisão.

Certamente, essa configuração específica da relação de poder entre administração prisional e presos, na PJPN, fez com que historicamente essa unidade recebesse mais projetos sociais que sua vizinha PDAM. 
O diretor associa ainda o grande número de ações na PJPN ao impacto dos projetos que já vinham sendo realizados na unidade. Para ele, a difusão dos projetos já em curso no sistema prisional é um dos fatores para o aumento do interesse da sociedade civil, e logo, do número de ações no cárcere:

"Você já tá vindo aqui há quanto tempo? Há uns quatro anos? Então você conversa com outras pessoas, tal, em uma reunião ou qualquer coisa, a pessoa até fica interessada, podem até não vir, e conversa com outras, as outras entram em contato com a gente".

Em relação ao impacto do GDUCC na unidade prisional, Dr. Daniel aponta que os presos participantes "se destacam um pouco mais", e tem um papel importante no envolvimento de outros presos:

"Para o preso, é bom para ele, adquire mais conhecimentos. Você vê os presos que trabalham aí com vocês, são os presos que se destacam um pouco mais, e também influenciam outros a participar."

O diretor destaca ainda a contribuição do juiz da VEC de Guarulhos nas inciativas desenvolvidas na PJPN:

"Ele também tem ajudado, ele tem sentido que nessa unidade o pessoal tem interesse em fazer as coisas, isso é muito importante. Ele tem se esforçado na Semana de Ciência, ele conversou com pessoal do Senai e arrumou cursos para presos do semiaberto."

Dr. Daniel louva a atitude participativa do juiz, que além de apoiar e incentivar os projetos sociais, é presença constante na unidade:

"Até uns três anos atrás, antes do Dr. Ricardo vir pra cá, era muito difícil...O juiz da execução que tinha aí, ele não vinha aqui no presídio. $\mathrm{O}$ Dr. Ricardo vem, ele atende oito presos (quatro do fechado, quatro do semiaberto), pergunta, fala com preso, qual a situação do preso. Vê se em outros presídios o juiz faz isso aí?"

A maior e mais comum preocupação da população prisional é a liberdade. Por isso, os encaminhamentos do processo de execução penal é um tema tão caro aos presos. A presença na unidade do juiz, responsável direto pela execução penal daqueles encarcerados, tem forte impacto prático e simbólico na prisão. 
A seguir, na apresentação da última das personagens deste jogo de cena, analisarei essas e outras implicações da postura do magistrado no cárcere e nos projetos de intervenção na sociedade.

\subsubsection{Juiz}

"O juiz é uma pessoa capacitada, tem cultura, conhecimento...mas ele poderia sair da única ignorância que ele tem: de como é executada a pena." 304

Por mais paradoxal que seja, é comum que os juízes criminais estejam distantes e alijados da forma que assume a execução penal no dia-a-dia prisional. O último personagem desse jogo de cena é um juiz que parece querer sair dessa ignorância apontada por um dos presos entrevistados.

Dr. Ricardo é juiz de execução criminal da Comarca de Guarulhos do Estado de São Paulo, que abrange quatro estabelecimentos prisionais (duas Penitenciárias e dois Centros de Detenções Provisórias), dispostos em um quadrado e atravessados pelas Rodovias Dutra e Ayrton Senna. Ele, sozinho, é responsável por mais de 12.000 processos de execução penal.

Conheci o magistrado em um encontro de encerramento da atividades do GDUCC na PJPN, em novembro de 2008. Pela primeira e única vez na história do grupo, formamos uma roda com um conjunto representativo de atores da reintegração social: presos, acadêmicos, ASPs, diretor da unidade prisional e o juiz de execuções criminais.

Os internos foram alertados, por outros presos e por funcionários da penitenciária, a não interpelarem o juiz com fins a obter informações acerca de seus processos. Ainda que a reunião de avaliação tenha ocorrido como o previsto, a presença das autoridades e de pessoas externas ao grupo, trouxe uma excitação ao grupo e certamente impactou a fala dos participantes, que passaram a ser dirigidas, ao juiz, com fins a passar uma boa imagem pessoal e da população prisional daquela unidade.

\footnotetext{
${ }^{304}$ Caderno de Campo, GDUCC, PJPN, setembro de 2009.
} 
Em outubro de 2011 entrevistei o referido juiz no seu gabinete no Fórum de Guarulhos. Optei por não utilizar o gravador, pois achei que o registro poderia inibir a discussão de alguns temas. Mesmo assim, houve um assunto delicado diante do qual Dr. Ricardo pediu inclusive que eu não fizesse anotações.

Depois de mais de duas horas de conversa, acompanhei ele e sua secretária a uma visita ao semiaberto da PJPN, para participar de uma atividade do "Projeto Como Vai Seu Mundo?"305. Chegando na unidade, ainda encontramos um professor, com dezessete alunas e um aluno do curso de Psicologia da Universidade Presbiteriana Mackenzie, que estavam visitando a unidade.

Desde o início de 2009, Ricardo tem incentivado projetos e mostrado uma aguda sensibilidade para a reintegração social. Além de acompanhar de perto as atividades do GDUCC, o magistrado apoia e promove uma série de outros projetos na sua Comarca, entre os quais: "Projeto Como Vai Seu Mundo?", oficinas de teatro e um curso de gastronomia $^{306}$.

Ademais, realizou duas parcerias: uma com o SENAC para a concessão de bolsas integrais para alguns presos, e outra com a Secretaria do Meio Ambiente para conquistar o "selo verde" pela primeira vez em um estabelecimento prisional. O juiz afirma que na PJPN: “90\% dos presos estão envolvidos com alguma atividade, "não estão jogando futebol”.

Senti o impacto da pro-atividade do referido juiz ao voltar a visitar os estabelecimentos prisionais, no segundo semestre de 2011. Em um ano que fiquei distante do campo paulista, percebi mudanças consideráveis nas unidades de Guarulhos.

Certamente, a postura ativa do Dr. Ricardo contribuiu para a entrada da sociedade no cárcere, e para a diversificação da rotina prisional. Nos últimos dois anos, multiplicaram-se os projetos sociais nas penitenciárias sob sua responsabilidade, e houve um sensível aumento de visitantes de fora, principalmente estudantes universitários, que contam com o juiz para intermediar o processo de autorizações de entrada.

\footnotetext{
${ }^{305}$ Realizado em parceria com o Instituto Crescer. Mais informações: http://institutocrescer.org.br/projetosdo-ic/projeto-como-vai-seu-mundo/, acesso 07/01/2012.

${ }^{306}$ Ministrado por Alex Atala, reconhecido chefe de cozinha brasileiro.
} 
O juiz criou a "entrevista semanal virtual”, na qual dá informações acerca dos processos de execução por videoconferência ${ }^{307}$, reconhecida por vários informantes como uma ótima medida de atenção ao preso. Nas diversas visitas que presenciei do juiz às unidades prisionais, foi comum que os presos se dirigissem a ele ou à sua secretária perguntas acerca de seu processo.

O magistrado se reconhece enquanto "agente político", uma vez que sua atividade conta com grande repercussão social. Em uma mistura de boa vontade, empreendedorismo e autopromoção, ele fala em mudar o paradigma carcerário em São Paulo, e até no Brasil. Segundo ele:

"Perdi a crença no meu trabalho porque cada vez mais a sociedade busca só a contenção do preso (...) Acho que ninguém pode ressocializar ninguém não gosto dessa palavra, ter que adaptar alguém as normas sociais positivadas" 308

Para Dr. Ricardo o objeto principal do juiz de execução criminal não é julgar benefícios,

"entendo que essas iniciativas são fundamentais para que eu alcance o objetivo do meu trabalho, que é a efetiva ressocialização de o maior número de presos. Como atingimos esse objetivo? Com resgate do dialogo entre sociedade e cárcere."

No diagnóstico do magistrado, falta protagonismo para os agentes envolvidos na execução da pena, e ele provoca juízes para que estejam presentes nas unidades prisionais:

“juiz de execução penal não pode ser só um juiz de gabinete, tem que ir a campo."

O magistrado parece ter muito bem elaborado o discurso que reveste suas práticas: para ele, o antigo paradigma no estabelecimento carcerário impedia o diálogo entre preso e sociedade, e, por conta desse paradigma, houve uma "cizânia entre sociedade e cárcere".

${ }^{307}$ A iniciativa foi objeto de inúmeras reportagens. Entre as quais: "Juiz adota videoconferência para beneficiar presos de Guarulhos" do Tribunal de Justiça de SP, Disponível: http://www.tj.sp.gov.br/Noticias/Noticia.aspx?Id=12235, acesso 20/12/2011.

${ }^{308}$ Caderno de Campo GDUCC, PJPN, novembro de 2008. 
É interessante notar os recursos de linguagem utilizados pelo juiz. Em diversos momentos da entrevista, ele repete a palavra cizânia ${ }^{309}$ para qualificar a relação entre preso e sociedade. E utiliza a noção de paradigma para se referir à presença e domínio das facções criminosas das unidades prisionais.

Em referência indireta às facções criminosas, relata que:

"por muito tempo, o cárcere era um coletivo desvinculado da sociedade. No cárcere, aprendiam uma série de regras de proceder, e na rua, voltavam para a vida do crime"

Mais interessante ainda é o fato dele diagnosticar uma mudança no paradigma da prisão. $\mathrm{Na}$ entrevista, ele fez uso do tempo passado para se referir ao domínio das facões criminosas nos estabelecimentos prisionais. Por exemplo, quando ele menciona o "antigo paradigma no estabelecimento penitenciário", ou quando relata que "o cárcere era um coletivo", ou mesmo ao afirmar que "no cárcere aprendiam as regras de proceder", como se hoje não existisse mais o código de conduta dos presos, que os define como presos com ou sem proceder $^{310}$.

Para o juiz, a organização dos presos em torno desse código de conduta trouxe sérios impactos ao cárcere e ao preso:

“o preso acabou transformando o estabelecimento carcerário em um coletivo próprio, regido por normas de conduta que transformaram o preso em um ser desindividualizado"

Como discuti em pesquisa anterior (Braga, 2008), ainda que a facção possa intensificar esse processo ao constituir mais um poder que sujeita o preso, o projeto do cárcere desde sempre esteve relacionado com a produção de um "ser desindividualizado".

${ }^{309}$ A palavra cizânia originalmente designa o "joio": planta gramínea, nociva, que nasce entre o trigo , que deu origem a expressão "separar o joio do trigo". No sentido figurado designa discórdia, desarmonia. Fonte: http://www.priberam.pt/dlpo/default.aspx?pal=ciz\%C3\%A2nia, acesso 12/01/2012.

${ }^{310}$ Sobre esse tema, fundamental a leitura da dissertação de mestrado em Antropologia Social (USP) de Adalton Marques (2009): Crime, proceder, convívio-seguro: um experimento antropológico a partir de relações entre ladrões. 
Nesse sentido, e ao contrário do que indica a fala do magistrado, a desindividualização da pessoa presa e a cisão com a sociedade livre não tem origem na organização dos presos. A separação física e social dos encarcerados com o mundo livre, o impacto da prisão na identidade dos presos, e a organização deles em coletivos são três produções antes da própria instituição prisional do que dos presos.

Para o magistrado, o objetivo dos projetos da sociedade:

"é mostrar para o sentenciado que ele tem outras opções de vida. Uma das frases que estamos usando como slogan é "A sala de aula é a porta pra liberdade.".

O slogan e a marca do juiz parecem ter se difundido nos estabelecimentos prisionais paulistas. Por duas vezes, em entrevistas com Agentes Penitenciários, foram mencionados a figura do Dr. Ricardo e seu lema.

Pesquisando acerca do projeto Leiturativa apresentado no capítulo anterior, encontrei, no blog do projeto $^{311}$, diversas referências ao projeto cultural “Como vai seu mundo?”, em curso no semiaberto da PJPN, e que tem o apoio do juiz e a coordenação de um então famoso preso da unidade, o rapper Dexter. O Dr. Ricardo é representado nos textos como um juiz preocupado com a ressocialização do preso.

Reproduzo abaixo um dos textos do blog, no qual um preso anuncia seu futuro frente à desativação da unidade ${ }^{312}$ em que estava cumprindo regime semiaberto:

"Disseram que poderíamos optar para onde irmos, porém esta decisão não tinha tempo de se avaliar para onde ir com tranquilidade, ou seja, não temos tempo pois as transferências serão amanhã.

Podemos dizer que dentro do que já se conhece do sistema carcerário, as opções foram poucas devido às circunstâncias, mas todos conseguiram declinar sua opção, e assim foi feito. Conforme as opções, se fizeram as transferências, as que foram para a capital foram no mesmo dia, e as que foram para o interior nos dias seguintes. Eu e mais alguns fomos para Guarulhos, onde teríamos uma mudança de execução, e as notícias que tínhamos a respeito do Juiz Corregedor da

311 http://projeto-leiturativa.blogspot.com/, acesso 21 de agosto de 2011.

312 Centro de Progressão Penitenciária de São Miguel. 
comarca de Guarulhos, era de um Juiz que desenvolvia um trabalho de reinserção do reeducando na sociedade"

A figura do Dr. Ricardo é emblemática. Em três anos de contato com ele, já formei diversas opiniões a seu respeito. Ao mesmo tempo que tem um comportamento extremamente polido, nas pequenas atitudes deixa escapar um certo autoritarismo, como quando reage com rispidez à interrupção de nossa entrevista pela entrada em seu gabinete dos funcionários do fórum. Da mesma forma, nas vezes que o acompanhei ao cárcere, percebi que, por maior o esforço que tivesse em se mostrar à vontade naquele ambiente, sua postura e olhar distante revelavam sua dificuldade na interação espontânea com os encarcerados.

Apesar de todos reconhecerem a disponibilidade e postura diferenciada de Dr. Ricardo, ele foi visto com desconfiança pelos presos com que conversei durante a visita do magistrado ao semiaberto da $\mathrm{PJPN}^{313}$. Primeiro, porque eles atribuíram sua boa vontade ao desejo de conseguir uma promoção na carreira. Um dos presos me falou ${ }^{314}$ literalmente que "ele está fazendo toda esse circo porque quer ir para o Tribunal". Outros o acusam de "só conceder benefícios àqueles que estão nos projetos”, e não julgar positivamente os demais casos.

Inclusive, no encontro posterior à primeira participação do juiz em uma roda do GDUCC em 2008, relatada anteriormente, realizamos um debate com os presos acerca da presença do magistrado que traria dados muito ricos em termos de reintegração social. A maioria relatou que não se sentia à vontade na presença do juiz, e mostravam-se indignados porque ele não julgava os benefícios. Segundo um deles: "não adianta nada esse discurso bonito, se ele na hora de julgar não solta ninguém"315.

Em entrevista com o agente de segurança penitenciária Ivan, ao comentar acera da dubiedade da figura do juiz que, ao mesmo tempo em que apoia a entrada da sociedade é conhecido como juiz "linha dura" pelos presos, o ASP comenta ${ }^{316}$ :

\footnotetext{
313 Outubro de 2011.

${ }^{314}$ Conversa informal com preso do semiaberto da PJPN, no dia da minha visita acompanhando o juiz.

${ }^{315}$ Caderno de campo GDUCC, PJPN, novembro de 2008.

${ }^{316}$ Entrevista ASP, PDAM, outubro de 2011.
} 
"o contato dele com os presos mudou a personalidade dele, o fato de ele participar mais nas unidades, refletiu no julgamento, deixou de ser tão duro".

A mesma impressão tem outra ASP entrevistada ${ }^{317}$ :

"tanto que assim, o que ele tem concedido de benefício progressão... O Dr. Ricardo era uma pessoa muito fechada, e assim, o beneficio era muito demorado, muito negado, indeferido. Depois do trabalho do GDUCC que ele acompanhou e depois da Feira que ele viu e gostou do trabalho... e a quantidade de benefício que ele concedeu foi maravilhosa"

Para um dos presos entrevistados ${ }^{318}$, a mudança do juiz também esteve associada ao impacto dos projetos de intervenção no cárcere:

"o juiz mudou. Pensou que, se os estudantes estão vindo, ele deveria se interessar, olhar por outro prisma".

Pelos depoimentos acima, o contato do magistrado com o cárcere impactou sua forma de perceber o preso e até de julgar. Certamente, as visitas às unidades prisionais, conversas com presos e participação em projetos da sociedade despertaram uma outra sensibilidade no juiz para a questão prisional.

Porém, a porta da liberdade indicada pelo juiz ainda é muito estreita para abranger a quantidade e diversidade das pessoas que estão na prisão. A educação nos estabelecimentos prisionais, formal ou informal, ainda é precária. Nesse sentido, vincular a concessão de benefícios à participação das pessoas encarceradas em projetos sociais e educacionais traz quatro perigos:

- que os projetos sejam instrumentalizados pelos presos e pela administração penitenciária. Nesse sentido, os encontros sociedade-cárcere passam a ter o fim utilitário de ser um caminho para alcançar benefícios;

- que na disputa interna por uma vaga nos projetos, saiam privilegiados os presos com mais poder na população prisional, e melhor relacionados com a administração penitenciária;

\footnotetext{
${ }^{317}$ Entrevista ASP, PJPN, julho de 2010.

${ }^{318}$ Entrevista a preso participante GUCC, PJPN, junho de 2010.
} 
- que seja acentuado o critério subjetivo para o julgamento de direitos subjetivos em sede de execução penal, em detrimento do critério temporal objetivo;

- que as ações da sociedade civil sejam absorvidas pela instituição prisional e pelo jogo prêmio-castigo da prisão, comprometendo a independência do projeto;

Encerro este jogo de cena com esses alertas para um novo cenário que parece estar se configurando no campo paulista. Nos três anos que decorreram do início desta pesquisa, ampliou-se a presença da sociedade civil nos estabelecimentos prisionais paulistas (PNPJ e PDAM) que compuseram essa cena. Porém, o jogo da prisão é sempre imprevisível; um desequilíbrio no arranjo de poder entre Estado e população prisional, ou uma mudança no quadro ou na política da administração penitenciária paulista, pode mudar a direção que parece tomar essa história da reintegração social em São Paulo.

\subsection{Movimento inacabado e experiência de aprendizagem: alguns temas}

\subsubsection{Desconfiança do preso}

“Aqui na prisão é como pisar em ovos". Essa foi a frase que ouvi de um dos presos participantes do GDUCC no ano de 2007 quando conversávamos acerca das normas que regulavam a vida na prisão. Essa imagem parece sintetizar a forma como se dão as relações no espaço prisional, seja pelo controle institucional, seja pelos próprios presos.

Conforme a fala de outro preso, "Uma coisa aprendi no cárcere: não venha falar meias palavras. Nós presos, temos uma regra. Graças a isto, dentro do cárcere nunca apanhei”’319.

A desconfiança e a cautela são mecanismos de sobrevivência no ambiente hostil do cárcere, que comprometem a capacidade de desenvolver relações afetivas, espontâneas e desinteressadas naquele espaço

Logo, é comum que os encarcerados recebam com receio as pessoas da sociedade civil estanhas ao ambiente prisional. Um sentimento comum aos presos que participam do grupo pela primeira vez é a desconfiança em relação aos propósitos do grupo. A relação entre os participantes do grupo não é totalmente desinteressada. Os presos sabem que os

\footnotetext{
${ }^{319}$ Caderno de Campo, GDUCC, PJPN, abril de 2008.
} 
acadêmicos vão à prisão alimentados por uma curiosidade intelectual e pessoal, e tem receio de se tornarem mais uma vez "objeto", seja de estudo, seja no processo penal.

Reproduzo abaixo algumas frases de presos que ilustram a desconfiança do interno em relação ao GDUCC, muitas das quais associam o projeto a um experimento de laboratório:

- "A gente sabe que não vai ter nenhum tipo de troca de informação, é só troca de conhecimento, mas e pra colocar isso na cabeça de um cara que tá tirando dez anos de cadeia? Ah não, tá vindo aqui pra investigar a gente, vai falar com o juiz não sei o quê, isso ai dá um nó meio que no grupo todo." 320

— "Estão usando a gente como cobaia, querem saber como está a cabeça." 321

- "No início não tinha interessado. Porque eu achei que o preso era objeto de estudo, ia ter que ficar falando..." 322

" "Eu não acredito no GDUCC. Acredito nas pessoas. Mas não confio em ninguém....."323

- "Somos ratinho branco de laboratório de vocês pesquisadores. Eu sei como é aqui, você não sabe. Usa-me (sic)."

- "De certa forma essa experiência é um laboratório, porque as pessoas estão tendo um convívio, com a prisão, com o preso, que elas não tem normalmente."

Do relato dos presos, pode-se depreender que um dos cuidados a ser observado pelos proponentes da intervenção é o de relacionar-se com o preso desde outro local, que não o do exame, aonde o preso é objeto de análise e não sujeito de ação.

O êxito da intervenção no cárcere depende da difícil tarefa de conquistar a confiança dos presos, e propor uma forma de interação dialógica com o cárcere. Daí a importância do comprometimento do grupo com os pressupostos da reintegração social e da sinceridade da relação estabelecida com preso.

\footnotetext{
${ }^{320}$ Entrevista a preso participantes, PJPN, julho de 2010.

${ }^{321}$ Caderno de Campo, GDUCC, PJPN, agosto de 2009.

${ }^{322}$ Caderno de Campo GDUCC, PJPN, novembro de 2009

${ }^{323}$ Caderno de Campo GDUCC, PJPN, novembro de 2009
} 


\subsubsection{Seleção dos presos}

A forma de seleção dos presos e presas participantes dos projetos de intervenção foi um dos temas que permeou a presente tese. Uma das principais dificuldades enfrentadas, pelo GDUCC e por outros projetos, foi a de conseguir atingir o público alvo determinado na proposta de intervenção. Os interesses, tanto da administração penitenciária quanto das organizações dos próprios presos, sobrepõem-se aos critérios do grupo, que, na maior parte das vezes, é excluído dessa tomada de decisão.

Apesar de nós do GDUCC termos solicitado diversas vezes a participação de "presos do fundão" nas nossas atividades, justamente porque muitos deles não fazem nada fora do pavilhão e tem poucas oportunidades na prisão, em cinco anos, nosso pedido nunca foi atendido.

Uma característica comum aos subgrupos do GDUCC, em especial na PJPN, é a presença maciça dos presos evangélicos, que realçam a função redentora da pena, a oportunidade de reflexão, legitimando a vinculação da pena no sentido da Igreja, enquanto penitência ${ }^{324}$.

Esse viés no perfil dos presos aparece no relatório de uma das acadêmicas do GDUCC:

\footnotetext{
"esse mesmo preso contara-me que os presos que fazem parte do GDUCC querem sair do crime, por serem a maior parte membros da Igreja, mas que os outros, a maioria dos presos, com os quais não tínhamos contato, não queriam sair do crime", 325 .
}

O problema da ingerência do centro penitenciário nesse processo de seleção é que a escolha é pautada com o fim de atender aos interesses da administração prisional. Nesse sentido, critérios estranhos aos fins de intervenção (como segurança, comodidade, privilégios) passam a determinar a escolha dos participantes por parte da administração prisional.

A ASP responsável por selecionar os presos participantes do GDUCC na PJPN atribui não à administração prisional, mas aos próprios presos, esse viés na seleção:

\footnotetext{
${ }^{324}$ Caderno de campo GDUCC, PJPN, reunião de supervisão setembro 2010.

${ }^{325}$ Relatório de acadêmica participante, PJPN, 2010.
} 
"Agora eu voltei a tentar atingir o restante da população. Eu só sinto uma coisa, um dos objetivos do GDUCC que não foi atingindo, que é justamente acessar o preso mais excluso, né? Que geralmente esse presos ficam no pavilhão $3^{326}$ e muitas vezes, mesmo requisitando, eles não conseguem ter acesso porque eles são barrados por outros presos, uma situação que eu não concordo. Que é o método de trabalho atual que possibilita esse tipo de coisa. Que na minha época, eu como ASP entrava no pavilhão retirava ele da cela e trazia" 327

O problema da ingerência das facções criminosas na seleção dos presos também foi apontado pela coordenadora do "Curso transdisciplinar de criminologia penitenciária e execução penal" na PFS, conforme apontado no capítulo anterior.

Em ambas as penitenciárias, PDAM e PJPN, foi comum a presença no grupo de presos que se diziam lideranças das facções na unidade prisional em questão. Na PJPN, esse viés apareceu mais acentuado. Na edição do segundo semestre de 2011, o grupo contou com a participação de presos conhecidos no sistema, que possuíam alto grau de elaboração discursiva.

A intervenção da sociedade civil no cárcere não se pode sobrepor à organização anterior de forças na dinâmica prisional. Nesse sentido, algumas configurações do espaço prisional mostram-se intransponíveis para aquele que vem de fora.

Assim, a intervenção no cárcere corre o risco de, ao invés de ser um espaço de participação democrática no presídio, funcionar como privilégio para presos com mais poder dentro da hierarquia prisional. Conforme já apontado anteriormente, esse risco é acentuado quando a

\footnotetext{
${ }^{326}$ Para ilustrar as diferenças na composição dos Pavilhões. Reproduzo um trecho do Caderno de Campo GDUCC, PJPN; março de 2007 “A penitenciaria em questão é composta por três pavilhões. O Pavilhão 1 logo em frente a saída da escola e mais próximo a entrada da prisão, abriga os presos engajados no projeto de reinserção, que frequentam a escola e/ou trabalham nas oficinas, e são vistos pelo sistema como "menos conflitivos". Entramos com um grupo de aproximadamente 20 pessoas, em sua maioria alunos da graduação da Faculdade de Direito da USP, os presos, que jogavam bola pararam, nos posicionamos espontaneamente na forma de um semicírculo na quadra, enquanto os presos permaneciam distantes, desconfiados. Depois de alguns minutos começamos a nos apresentar e interagir timidamente e com certa formalidade. Mas adiante no corredor se encontram os outros dois pavilhões um do lado do outro, e ao final as celas de castigo e seguro. $\mathrm{O}$ Pavilhão 3 se encontra do lado esquerdo do corredor abriga os presos "mais complicados" para o sistema, e em geral, não participam das atividades propostas pela penitenciária. Nos deixaram entrar em no Pavilhão 3 (mas rapidamente pois já acabara o tempo da visita). A dinâmica que se impôs assim que pisamos o pé no pátio foi totalmente diversa do pavilhão anterior. Uma serie de presos se aproximaram e começaram a perguntar quem éramos e fazer alguma denuncia do cárcere, me lembro de um até ter me oferecido seu numero de celular para eu ligar caso realmente quisesse saber o que passava no cárcere."

${ }^{327}$ Entrevista a ASP, PJPN, julho de 2010.
} 
participação nesses projetos influi diretamente no julgamento dos direitos subjetivos penitenciários (progressão de regime, liberdade condicional, etc.).

Nesse sentido, o posicionamento do juiz da VEC de Guarulhos acerca do público alvo das ações de reintegração social também tem um impacto na configuração dos projetos:

"O cara que é fundão nato não vai sair de lá, é um tipo que muito dificilmente vai se obter a reinserção social, já o "fundão acidental é o "cara que entrou sem suporte, não tem grau na hierarquia da facção criminosa. Esse preso que queremos atingir"

A fala do juiz destoa da proposta de reintegração social do GDUCC por dois motivos. Primeiro porque os termos nato e acidental remetem-nos a uma visão determinista, que se aproxima da tipologia proposta por Cesare Lombroso da Escola Positivista Italiana. E, depois, o GDUCC sempre buscou trabalhar com o que o juiz chamou de "fundão nato", que, para nós coordenadores, era formado pelas pessoas que sofriam mais agudamente o processo de prisionização.

\subsubsection{Diálogo compreensivo e dialético}

Um dos temas que permeou o trabalho do GDUCC nesses anos foi o equilíbrio entre uma postura compreensiva e dialética no diálogo com os presos. A via da reintegração social supõe que os membros da sociedade respeitem as escolhas éticas do preso e o conheçam para além do ato criminoso.

Essa postura destoa das concepções da sociedade em relação aos presos. Ilustro esse embate narrando uma pequena história. No primeiro dia da edição do segundo semestre de 2011 do GDUCC, presenciei a crise de uma aluna que dizia que estava confusa, porque sua mãe a havia alertado que era perigoso a prisão, e "que os presos não ligavam pra ela", enquanto o pessoal do GDUCC falava para "aceitar os presos". Ela não sabia como se posicionar.

A partir do processo de interação social na prisão é comum a transformação na forma dos acadêmicos enxergarem o preso. Essa transformação passa pela descoberta de uma face da personalidade do preso abafado pela cárcere e pelo estigma de criminoso. Foi comum nos 
relatórios acadêmicos, que eles se referissem aos "lados bom e mau" do preso, e se surpreendessem positivamente com manifestações do seu "lado bom". Como no seguinte relato:

\begin{abstract}
"Em uma das primeiras reuniões, o professor Alvino Augusto de Sa nos explicou o significado do GDUCC e salientou que não estávamos lá para tentar mudar a mentalidade de nenhum dos presos, mas sim, para principalmente ouvi-los e aprender que o ser humano tem o seu lado bom e o seu lado ruim. Dependendo das circunstâncias, uma pessoa deixa seu lado mal prevalecer sobre seu lado bom"
\end{abstract}

O diálogo entre sociedade e cárcere possibilita a compreensão por parte dos envolvidos do processo de vida do outro. De tal forma, que a comunicação se sobreponha a distância e rigidez no julgamento da ação do outro e possa levar a um encontro personalizado no cárcere. Como no relato de um dos acadêmicos:

"Essa história (preso fez uma festa para um menino da vizinhança, porque ele nunca tinha tido uma), que emocionou a todos nós, mais uma vez demonstrou o quanto os presos também são capazes de atitudes generosas e belas como estas, que não podem ser esquecidas e desprezadas em face do erro que os levou a estar atualmente presos" ${ }^{328}$

Para Molina (1997: 189) o maior êxito das intervenções no cárcere, é o encontro pessoal e personalizador entre presos e alunos participantes, frente à despersonalização comum à vida na prisão. De forma que o encontro possibilite um interação social que ultrapasse a divisão dos muros:

"Na última visita à Penitenciária Parada Neto, eu finalmente entendi o que o professor queria dizer com este ensinamento. A banda dos presos tocou Legião Urbana e todos cantaram juntos. Naquele momento éramos todos seres humanos, não éramos presidiários e estudantes ou profissionais do Direito ou da Psicologia ou professores. E eu vi o lado bom de homens que cometeram crimes, alguns crimes horríveis, como homicídios. Alguns dos detentos inclusive nos agradeceram pelas visitas e pela oportunidade que demos a eles. Senti que o que esses homens precisavam era realmente de um diálogo franco, sem análises psicológicas, mas sim, o diálogo proposto pelo GDUCC. Nesses meses, por vezes, questionei-me como homens que se revelaram simpáticos e receptivos puderam cometer os crimes e então lembrei do lado mal que cada um possui em si”,329

\footnotetext{
${ }^{328}$ Relatório final de acadêmica, PJPN, 2010.

${ }^{329}$ Relatório final de acadêmico, PJPN, 2010.
} 
Essa perspectiva cria um ambiente aparentemente propício à reintegração, já que os presos se sentem sinceramente acolhidos pelos membros da sociedade, e vice-versa. Porém, ela pode levar a idealização dos presos das relações afetivas com a pessoa de fora e vice-versa.

Ainda que seja positivo que os acadêmicos vejam o preso para além de sua relação com o sistema de justiça, insistir nessa dicotomia pode dificultar a compreensão do ser humano em sua totalidade e levar a idealização dos presos pelos participantes.

Os próprios presos parecem negar o lugar de vítima de um sistema de justiça seletivo, comuns nas concepções da chamada criminologia crítica. Conforme a fala de alguns deles:

- "Dentro do crime se colocar em uma posição de vitima é muito pior",330

- "Coitadinho não cola aqui. O cara que se paz de coitadinho passa a ser a própria vitima do sistema" 331

- “A gente se responsabiliza pela nossa pena, mas não do jeito que ela é aplicada. Ai somos vitimas do sistema" 332

Logo, o diálogo no cárcere além de compreensivo deve ser dialético. A interação no cárcere deve abranger também o conflito, o enfrentamento. De forma que o encontro dos presos e dos acadêmicos vaiam além da reafirmação da humanidade bondosa dos participantes para atingir de forma mais profunda a complexidade do conflito sociedadecárcere.

\footnotetext{
${ }^{330}$ Caderno de Campo, GDUCC, Parada Neto, out/2009

${ }^{331}$ Caderno de Campo, GDUCC, Parada Neto, out/2009

${ }^{332}$ Caderno de Campo, GDUCC, Parada Neto, out/2009
} 


\section{CONSIDERAÇÕES FINAIS}

Com a presente tese busquei discutir a concepção e práticas da reintegração social, a partir das diversas formas que a intervenção da sociedade civil assume no cárcere. Meu foco foi a análise dos programas de intervenção crítica no contexto penitenciário, vislumbrando-os como possibilidades de construção de uma nova política de verdade acerca do preso e da prisão.

Busquei enfrentar alguns temas e dificuldades comuns às propostas de intervenção no cárcere, dentre os quais destaco:

- a falta de referências de outros trabalhos, que possibilitem aprender com erros e acertos de outra experiência, de conhecer outros modos de fazer;

- dificuldades pessoais de se realizar um projeto no cárcere. O impacto físico e emocional de se estar em uma prisão, o delicado equilíbrio entre a compreensão e o enfrentamento;

- apurar o conhecimento sobre o funcionamento daquele espaço, pensar as redes de poder (e o nosso lugar nelas), descobrir os limites do trabalho e as linhas de fuga, dialogar com os tempos e burocracias da prisão, com as interferências externas e internas, e ainda, com a presença das facções criminosas.

Diante do fechamento característico da instituição prisional, o primeiro desafio das entidades que queiram realizar projetos na prisão é conseguir inserir-se nesse espaço, nem sempre permeável à entrada da sociedade civil.

Porém, o início de um projeto no cárcere não é garantia de sua continuidade. Ao contrário, a permanência de pessoas externas à dinâmica prisional depende da capacidade delas de “jogar o jogo da prisão”, e de possuir capitais sociais e simbólicos valorizados nesse jogo.

Ademais, a abertura do cárcere pra sociedade está sujeita a uma série de circunstâncias externas e independentes das entidades da sociedade civil, que podem comprometer a continuidade da intervenção.

A entidade da sociedade civil que consegue permanecer no cárcere se depara com dois risco em relação à administração penitenciária: ser absorvida ou expulsa do cárcere. Nesse 
sentido, o principal desafio da intervenção passa a ser o de preservar a autonomia do projeto frente o exercício do poder institucional, que integra e domestica as ações que desafiam as configurações de poder no espaço prisional.

Propus considerar a reintegração social não como função da pena, mas como uma possibilidade de minimizar seus efeitos. Reproduzo a fala ${ }^{333}$ de uma ASP na qual ela sintetiza, de forma simples, a reintegração social:

"Reeducar e reintegrar são palavras pesadas, porque a pessoa já foi educada, já foi... Acho que reintegrar é melhor do que reeducar até, porque a pessoa já foi educada e reeducar é complicado, é como se você fosse lá, apagasse todos os conceitos que ela tem e crie conceitos novos na mentalidade dela... Reintegrar já é um pouco mais fácil, por quê? Porque você vai tentar só pegar a pessoa que está exclusa, tentar embutir conceitos novos e possibilitar que ela retorne ao meio social. A única coisa que tenho pra te falar, a importância de tentativa dessa reintegração é grande”

Logo, o que diferencia um projeto de reintegração social em relação ao projeto das chamadas ideologias "res" (ressocialização, reeducação, reabilitação) é que a intervenção com fins de reintegração social não busca a reforma moral do indivíduo, mas sim reduzir o impacto do emprisionamento sobre a pessoa presa. Para tanto, ela deve se focar não no preso, mas na interrelação social que abrange Estado, prisão e sociedade civil, de forma que esses sujeitos se comprometam na medida de sua responsabilidade.

Uma intervenção com o fim de reduzir o impacto da prisão na pessoa presa deve ter como objetivo mais amplo a modificação das estruturas penitenciárias. Na ausência desse objetivo a longo prazo, corre-se o risco das intervenções serem capturadas pela instituição prisional, de forma que a sociedade civil organizada seja instrumentalizada como poder disciplinar e de controle sob o individuo preso, ao invés de reduzir os impactos e as rupturas causadas pelo sistema de justiça criminal.

A potência da intervenção da sociedade civil está na criação de espaços mais democráticos no interior dos cárceres, e na diversificação das relações sociais no espaço prisional. Além disso, a presença de pessoas estranhas à dinâmica prisional relativiza a opacidade característica da prisão, incrementando o controle externo e a proteção contra os abusos de

${ }^{333}$ Entrevista a ASP, PJPN julho de 2010. 
poder. E, a longo prazo, pode influir na direção política do sistema penitenciária e na forma da sociedade se relacionar com o cárcere.

As ações de reintegração social se inscrevem no questionamento do tempo presente, desafiando suas certezas e irredutibilidades a partir da perspectiva passada e futura: "nem sempre fomos o que somos, nem sempre seremos o que somos" (Foucault, 1995:180); e então nos libertamos, com a certeza de que "nada precisa ser dessa forma". Não há dimensão social insuperável, ontológica, atemporal.

Novas formas de subjetividade podem advir do momento presente. Podemos recusar o que temos sido até então e construir outras formas de ser, de viver, de sentir, de agir. Essa potência do presente, a possibilidade de que, enquanto sujeitos da história, podemos transformar nossa relação com os outros e com nós mesmos, convoca-nos à ação, encorajando-nos a resistir.

Parte de mim acreditava que realizar qualquer projeto no cárcere significaria reafirmar ou legitimar essa instituição. Ao mesmo tempo, a existência de condições materiais e concretas, a dimensão de que existem homens e mulheres agora, no tempo presente, que sofrem ainda mais agudamente a ação desse mecanismo de poder, conclama-me à ação.

E justamente por minha alma querer abolir os mecanismos de exclusão, no momento presente, não só recuso a prisão, mas busco caminhos para resistir a ela. Como se a partir dela, apesar dela, e literalmente dentro dela, possa ser reduzido o espaço social e psíquico que ela ocupa em mim, e na sociedade. A simples recusa é ingênua, não há fora, por isso a urgência de entrar.

A resistência, porém, é ambivalente. Joga o jogo, faz concessões, submete-se. Somente a partir da topografia do campo prisional, e talvez de cada espaço específico, descobrem-se as brechas, as rochas, as trilhas; percebem-se os ciclos, o clima, os tempos.

O caminho da (re) integração social, diferentemente das ideologias de reabilitação, pressupõe que as partes em comunicação saiam transformadas a partir da experiência do encontro. É uma tentativa de congregar- resistir à segregação, de experimentar outras formas de nos relacionarmos com a culpa, com os erros, com o outro e com nós mesmos. 
Logo, quando escolho mergulhar no mundo sombrio da prisão para ali desenvolver um projeto de reintegração social, é uma opção por mergulhar na minha própria escuridão. Não é aos presos que quero libertar, mas a mim mesma. Como dizia Foucault "ser livre é fugir da servidão de si mesmo", essa servidão assídua, que pesa sobre nós dia e noite, sem folga. E por que não? Por que morrer em conjunto, se todos podemos viver? ${ }^{334}$ todos nós vivêssemos?" 


\section{BIBLIOGRAFIA}

ABRIR LA CÁRCEL. Memoria del Proyecto, 1999. Disponível em : http://acpes.8m.net/docs/MEMORIA.htm, acesso 19/02/2010.

ANGOTTI, Bruna. Breves notas sobre o abolicionismo penal in Revista IBCCRIM No 80 / 2009, pp. 247-279.

ARTIÉRES, Philippe, QUERO, Laurent e ZAANCATINI- FOURNEL, Michelle (orgs). Le group d'information sur les prisons. Archive d'une lutte 1970-1972. Paris: Editions de L'imec, 2003.

BARATTA, Alessandro. Ressocialização ou Controle Social: Uma abordagem crítica da "reintegração social" do sentenciado, 1990. Disponível em http://www.eap.sp.gov.br/ pdf/ressocializacao.pdf. Acesso em 02/11/ 2007.

BARBERO, Horácio Roldán. Introducción a la investigación criminológica. Granada: Editorial Comares, 2009.

BEIRAS, Iñaki Rivera. ¿Abolir o transformar? Buenos Aires: Editores del Puerto, 2010.

Bosh, 1999. . La cárcel en España en el fin del milenio. Barcelona: Editorial Maria Jésus

La cuestión carcelaria. historia, epistemología, Derecho y política penitenciaria: Volumen I. Buenos Aires: Editores del Puerto, 2009.

BAUMANN, Zygmunt. Globalização: as consequências humanas. Rio de Janeiro: Jorge Zahar, 1999.

. Social uses of law and order, in GARLAND, David, SPARKS, Richard Criminology and social theory. New York: Oxford University Press, 2000.

BECKER, Howard (1971). Los extraños. Sociología de la desviación. Buenos Aires, Tiempo Contemporáneo.

BERISTAIN, A. Derecho penal, criminología y victimología. Curitiba: Juruá Editora, 2007.

. Nova criminologia à luz do direito penal e da vitimologia. Brasilia: Editora Universidade de Brasília, 2000.

- Re-encantamiento criminológico en proximidad desde el des encantamiento. Madrid: Actualidad Penal, 1993, p. 343-359.

BIONDI, Karina; MARQUES, Adalton. Memória e historicidade em dois "comandos" prisionais. Lua Nova, v. 79, p. 39-70, 2010. 
BOBBIO, Norberto. Estado, Governo e Sociedade: para uma teoria geral da política. Rio de Janeiro: Paz e Terra, 1987.

. O conceito de sociedade civil. Rio de Janeiro: Graal, 1982.

BOURDIEU, Pierre (org). As misérias do mundo. Petrópolis: Ed. Vozes, 1999.

. Coisas ditas. São Paulo: Brasiliense, 2004.

$\overline{\text { Anagrama,1999 }}$

. La economía de los bienes simbólicos. Barcelona: Editorial

.Razões Práticas: sobre a teoria da ação. Campinas: Ed. Papirus, 1996.

. Réponses. París: Seuill,1992.

BRAGA, Ana Gabriela Mendes. A identidade do preso e as leis do cárcere. 2008. Dissertação (Mestrado em Direito Penal) - Faculdade de Direito, Universidade de São Paulo, São Paulo, 2008.

BRAGA, Ana Gabriela Mendes e BRETAN, Maria Emília. Teoria e prática da reintegração social: o relato de um trabalho crítico no âmbito da execução penal. In: SÁ, Alvino Augusto de; SHECAIRA, Sérgio Salomão.. (Org.). Criminologia Aplicada aos Problemas da Atualidade. São Paulo: Atlas, 2008, p. 255-275.

CAPELLER, Wanda Maria de Lemos. O direito pelo avesso: análise do conceito de ressocialização. Temas IMESC: Sociedade. Direito, Saúde. Volume 2,2, dez- 1985, p. $127-$ 134.

CASTRO, Lola Aniyar de. Criminologia da libertação. Rio de Janeiro: Revan/ Instituto Carioca de Criminologia, 1983.

CHANTRAINE, Gilles. La prison post-disciplinaire, Déviance et Société, 2006/3 Vol. 30, p. 273-288.

COHEN, Jean L. Sociedade civil e globalização: repensando categorias. Dados.vol.46, n.3, pp. 419-459, 2003.

CUNHA, Manuela Ivone. Investigar problemas sociais; equívocos e dilemas de uma etnografia da prisão, 1991. Disponível em repositorium.sdum.uminho.pt/bitstream/1822/.../AgenPubCunha.pdf, acesso 3/08/2009.

DA MATA, R. O ofício do etnólogo, ou como ter 'anthropological blues'. In: NUNES, E. O. (Org.) A aventura sociológica: objetividade, paixão, improviso e método na pesquisa social. Rio de Janeiro: Zahar, 1978

DAUFEMBACK, Valdirene. 2009. Questões sobre o contexto e a atuação dos Conselhos da Comunidade: a experiência da região Sul. 
Disponível http://portal.mj.gov.br/data/Pages/MJ57DC54E2PTBRIE.htm, acesso $13 / 05 / 2010$.

DEACON, Roger; PARKER, Ben. Educação como sujeição e como recusa. IN SILVA, Tomás Tadeu da (org) O sujeito da educação.Estudos foucaultianos. Petrópolis: Vozes, 2002.

DELEUZE, Gillles. Conversações. São Paulo: Editora 34, 1992.

DELGADO, Manuel. El animal publico. Barcelona: Editorial Anagramas, 1999.

DEFENSOR DEL PUEBLO. Informes, estudos y documentos, Situación Penitenciária en Cataluña, 1990. Disponível em: www.uned.es/dpto-derecho.../infdef90.pdf, acesso 3/11/2011.

DEPARTAMENT DE JUSTICÍA-.Experiències de tres voluntaries.- Catalunya, 2011 http://www20.gencat.cat/portal/site/Justicia, acesso 20/08/2011.

DI GIORGI, Alessandro. Miséria governada através do sistema penal. Rio de Janeiro: Revan, 2006.

DURKHEIM, Emile. Da divisão do trabalho social. São Paulo: Martins Fontes, 1995.

DUSSEL, Inés. Foucault e a escrita da história: reflexões sobre o uso da genealogia. Educação \& Realidade. Porto Alegre, v. 29, n.1, jan/jun. 2004.

ELIADE, Mircea. Tratado de história das religiões. São Paulo: Martins Fontes, 2010,

FAS- FUNDACIÓ AUTÒNOMA SOLIDÀRIA. Programa integració presos. http://www.uab.es/servlet/Satellite/programes-socials/justicia/activitats-i-centres1274251162339.html, acesso 07/10/2010.

FISCHER, Rosa Maria Bueno. Foucault revoluciona a pesquisa em educação? Perspectiva, Florianópolis, v.21, n.02, p. 371-389, jul/dez.2003.

FOLTER, Rolf S. de. Sobre a fundamentação metodológica do enfoque abolicionista do sistema de justiça penal - uma comparação das ideias de Hulsman, Mathiesen e Foucault in Verve, $\mathrm{n}^{\mathrm{o}}$ 14, 2008, pp. 180-215.

FOUCAULT, Michel. A palavra e as coisas. São Paulo: Martins Fontes, 2002.

. A propósito del encierro penitenciario. In Un diálogo sobre poder y otras conversaciones. Madrid: Alianza Editorial, 2008.

. A ordem do discurso. São Paulo: Edições Loyola, 1996.

Forense, 2006. Ditos e Escritos IV: Estratégia, Poder-Saber. Rio de Janeiro: Editora 
. Table ronde du 20 de mai 1978. In Perrot, Michelle. L'impossible prison. Paris: Editons du Seuil, 1980, p. 40-56.

2005.

História da Sexualidade. I, A Vontade de Saber. Rio de Janeiro: Graal, . Microfisica do poder. Rio de Janeiro: Graal, 1979.

. O que é a crítica? Cadernos da FFC, v. 9, n.1. Faculdade de Filosofia e Ciências, UNESP Marília, 2000.

. O sujeito e o poder. In: RABINOW, Paul; DREYFUS, Hubert. Michel Foucault. Uma trajetória filosófica. Para além do estruturalismo e da hermenêutica. São Paulo: Forense Universitária, 1995

.Segurança, Território, População. São Paulo: Martins Fontes, 2008.

.Un dialogo sobre el poder y otras conversaciones selección Miguel Morey. Madrid: Alianza editorial, 2008b.

GARLAND, David. As contradições da 'sociedade punitiva': o caso britânico. Revista de Sociologia e Política, 13: 59-80, nov., Curitiba, 1999.

- Entrevista à Revista Conciência, disponível no endereço http://www.comciencia.br/comciencia/handler.php?section $=8 \&$ tipo $=$ entrevista\&edicao $=35$ , acesso 23/04/2009.

.Punishment and Modern Society: a study in social theory. Chicago: Oxford University Press, 1990.

GEERTZ, Clifford. Uma descrição densa: por uma teoria interpretativa da cultura. In: $A$ interpretação das culturas. Rio de Janeiro: Zahar, 1978

GENERALITAT DA CATALUNYA. Subdirecció General d'Associacionisme i Voluntariat. La Intervenció en centres penitenciaris des del voluntariat : manual del curs I. 2007.

GINZBURG, Carlo. "O inquisidor como antropólogo: uma analogia e as suas implicações". In: A micro-história e outros ensaios. Rio de Janeiro: Bertrand, 1991. p. 20314.

GRACIANO, M. A educação nas prisões: um estudo sobre a participação da sociedade civil. 2010. 261 f. Tese (Doutorado)- Faculdade de Educação, Universidade de São Paulo, São Paulo. 
GODOI, Rafael. Ao redor e através da prisão: cartografias do dispositivo carcerário contemporâneo. 2010. Dissertação (Mestrado em Sociologia) - Faculdade de Filosofia, Letras e Ciências Humanas, Universidade de São Paulo, São Paulo, 2010.

GOFFMAN, Erving. Manicômios, Prisões e Conventos. São Paulo: Perspectiva, 2005.

HULSMAN, Louk. Alternativas à justiça criminal in PASSETTI, Edson (org.) Curso Livre de Abolicionismo Penal. Rio de Janeiro: Revan, 2004.

. La perspectiva abolicionista in Revista del Instituto de Ciencias Penales y Criminologia. Bogotá, Universidad Externado Colombia, nº 25, 1985.

.Temas e conceitos numa abordagem abolicionista da justiça criminal, in PASSETTI, Edson \& DIAS DA SILVA, Roberto Baptista (orgs). Conversações abolicionistas: uma crítica do sistema penal e da sociedade punitiva. São Paulo, IBCCRIM, 1997, pp. 189-213.

HUMAN RIGHTS WATCH, Relatório "Brasil atrás das grades", 1998. Disponível em http://65.202.220.120/portuguese/reports/presos/, acesso 16/06/2010.

JUNG, Carl Gustav. O eu e o inconsciente. Petrópolis: Vozes, 2003.

LARROSA, Jorge. A operação ensaio: sobre o ensaiar-se no pensamento, na escrita e na vida. Educação \& Realidade. Porto Alegre, v. 29, n.1, jan/jun. 2004.

LOUVAT, Thomas. Teatro en cárceles, s.d.. Disponível no site:

www.redlece.org/biblioteca/Louvat.pdf, acesso 25 de novembro de 2010.

MARQUES, Adalton Jose. Crime, proceder, convívio-seguro: um experimento antropológico a partir de relações entre ladrões. 2009. Dissertação (Mestrado em Antropologia Social) - Faculdade de Filosofia, Letras e Ciências Humanas, Universidade de São Paulo, São Paulo, 2010.

MATHIESEN, Tomas. La política del abolicionismo in COEN, Stan (org). Abolicionismo Penal, Buenos Aires: Ediar, 1989.

. Hva er KROM. ABOUT KROM - Past - Present - Future, 2000, disponível http://www.krom.no/hva_er_krom_more.php?id=89_0_26_0_C, acesso $15 / 03 / 2010$

- O caminho do século XXI- Abolição, um sonho impossível?In PASSETTI, Edson \& DIAS DA SILVA, Roberto Baptista (orgs). Conversações abolicionistas: uma crítica do sistema penal e da sociedade punitiva. São Paulo, IBCCRIM, 1997, pp. 262-287.

The politics of abolition. London: Martin Robertson, 1974.

MINISTÉRIO DA JUSTIÇA. DEPEN. Comissão para Implementação e Acompanhamento dos Conselhos da Comunidade. Cartilha Conselhos da Comunidade / Comissão para 
Implementação e Acompanhamento dos Conselhos da Comunidade. Brasília: Ministério da Justiça, 2008, $2^{a}$ edição.

MOLINA, Jésus Valverde. La cárcel y sus consecuencias. La intervención sobre la conducta desadaptada. Madrid: Editorial Popular, 1991.

OBRA COLECTIVA. La Cárcel Modelo de Barcelona 1904-2004. Barcelona: Ateneo Libertario Al Margen, Likiniano Elkartea, Etcétera, 2004. Disponível em http://www.sindominio.net/etcetera/PUBLICACIONES/con otros/modelo2.pdf, acesso 03/05/2010.

OSPDH Observatori del Sistema Penal i els Drets Humans de la Universitat de Barcelona. L'empresonament a Catalunya. Barcelona: Edicions 1984, 2004.

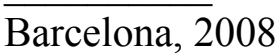

. Memoria 2011-2007. Barcelona: Publicacions i Edicions de la Universitat de

ORGANIZAÇÃO DAS NAÇÕES UNIDAS. Regras Minimas para o Tratamento de Prisioneiros .Disponível: http://www.direitoshumanos.usp.br, acesso 10/06/2010.

. Regras de Tóquio. Disponível em: http://www.gddc.pt/direitoshumanos/textos-internacionais-dh/tidhuniversais/dhaj-NOVO-regrastoquio.html, acesso $10 / 06 / 2010$.

PAPENDORF, Knut The Unfinished': Reflections on the Norwegian Prison Movement"; Acta Sociologica 2006; 49; pp. 127- 137.

PERANO, Jorge. Algunas pautas de trabajo desde la criminologia sobre el sistema carcelario. Revista de Derecho Penal y Procesal Penal, Buenos Aires, abril 2009, pp. 676684.

RESTREPO, Luis Alberto. A relação entre a sociedade civil e o Estado: elementos para uma fundamentação teórica do papel dos movimentos sociais na América Latina. Tempo Social: Revista de Sociologia da USP, S. Paulo, 61-100, 2.sem.1990.

ROCHA, João Luís, SILVÉRIO, Sofia Alexandra. Determinante rede social in ROCHA, João Luís (coord.) Entre a reclusão e a liberdade, vol. I. Coimbra: Livraria Almedina, 2005, pp. 243-302.

RUBIO, César Lorenzo. La revuelta de los comunes. Una primera aproximación al movimiento de presos sociales durante la transición, 2005. Disponível em

SÁ, Alvino Augusto de. Criminologia Clínica e Execução Penal. Proposta de um modelo de terceira geração. São Paulo: Editora Revista dos Tribunais, 2011. dos Tribunais, 2007.

Criminologia Clínica e Psicologia Criminal. São Paulo: Editora Revista 
- Direitos Humanos na Execução Penal In NALINI, José Renato e CARLINI, Angélica. Direitos humanos e formação jurídica. Rio de Janeiro: Editora Forense, 2010, pp. 119-136.

Sugestão de um esboço de bases conceituais para um sistema penitenciário, 2008. Disponível em:

www.sap.sp.gov.br/download files/reint.../sugestao esboco.doc, acesso 11/05/2010.

SALLE G. Mettre la prison à l'épreuve. Le GIP en guerre contre l' " Intolérable », Cultures et conflits, 55, 71-96. 2004.

SOUZA, Regina Maria de; GALLO, Silvio. Por que matamos o barbeiro? Reflexões preliminares sobre a paradoxal exclusão do outro. In Educação e Sociedade - Dossiê "Diferenças". Revista Quadrimestral de Ciência da Educação. N.79, ano XXIII, Agosto de 2002. Campinas, CEDES, UNICAMP, 2002.

SPRJJ - Secretaria de Serveis Penitenciaris, Rehabilitació i Justícia Juvenil. (2007) La intervenció en centres penitenciaris des del voluntariat. Manual de curs. Generalitat de Catalunya. Disponível no endereço

http://www20.gencat.cat/portal/site/Justicia/mD, acesso 26/04/11.

TURNER, Victor. O processo ritual. Petrópolis: Ed. Vozes, 1974.

YOUNG, Jock. A sociedade excludente: exclusão social, criminalidade e diferença na modernidade recente. Rio de Janeiro: Revan/ ICC, 2002.

ZAFFARONI, Eugenio Raúl. A criminologia como instrumento de intervenção na realidade. In Revista da Escola do Serviço Penitenciário, Porto Alegre: ano 1, n. 4 , setembro/1990.

Ed. Temis. 1998.

, Criminología: aproximación desde un margen. Santa Fé de Bogotá:

.Em busca das penas perdidas. Rio de Janeiro: Revan. 1991.

ZINO, Julio. "Coyunturas de cambio de una cultura institucional", Alter, Revista Internacional de teoría, Filosofía y Sociología Jurídica, Año I, México, 2001.

. El discurrir de las penas. Instituciones y trayectorias sociales. El caso de la prisión. Tesi doctoral, Departament d'Antropologia, Facultat de Geografia i Història. Universitat de Barcelona, 1996.

. Las trayectorias sociales en prisión y el proceso de identidad (1993), Arxiu d'Etnografía, $\mathrm{n}^{\mathrm{0}} 10, \quad$ Tarragona, 1999. Disponível em http://www.ub.es/penal/zino1.htm, acesso 20/05/2010.

WACQUANT, Loic. As Prisões da Miséria. Rio de Janeiro: Jorge Zahar Editor, 2001. 
WOLFF, Maria Palma, 2009. Participação social e sistema penitenciário: uma parceria viável? Disponível http://portal.mj.gov.br/data/Pages/MJ57DC54E2PTBRIE.htm, acesso 13/05/2010.

\section{ANEXOS}

\section{ANEXO 1- PESQUISA EXPLORATÓRIA}

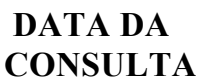

CONSULTA

\begin{tabular}{|c|c|}
\hline 13/10/09. & $\begin{array}{l}\text { Depen- Ministério da Justiça } \\
\text { http://portal.mj.gov.br }\end{array}$ \\
\hline $21 / 10 / 2009$ & $\begin{array}{l}\text { SAP-Coordenadoria de Reintegraçã } \\
\text { Social e Cidadania } \\
\text { http://www.sap.sp.gov.br }\end{array}$ \\
\hline $21 / 10 / 2009$ & $\begin{array}{l}\text { Secretaria de Estado de Defesa Socia } \\
\text { - MG } \\
\text { http://www.seds.mg.gov.br }\end{array}$ \\
\hline $21 / 10 / 2009$ & $\begin{array}{l}\text { CNPQ } \\
\text { http://dgp.cnpq.br/ }\end{array}$ \\
\hline $23 / 10 / 2009$ & $\begin{array}{l}\text { Rede Comunidade Segura } \\
\text { http://www.comunidadesegura.org/ }\end{array}$ \\
\hline $23 / 10 / 2009$ & $\begin{array}{l}\text { Complexo prisional Tihar- India } \\
\text { http://tiharprisons.nic.in/html/ } \\
\text { reform.htm\#yog }\end{array}$ \\
\hline $23 / 10 / 2009$ & $\begin{array}{l}\text { Povo Marcado/ TV Cela } \\
\text { http://povomarcado.blogspot.com/ } \\
\text { http://projetotvcela.blogspot.com/ }\end{array}$ \\
\hline $23 / 10 / 2009$ & $\begin{array}{l}\text { Pastoral Carcerária } \\
\text { http://www.carceraria.org.br/ }\end{array}$ \\
\hline
\end{tabular}

\section{REFERÊNCIA SIMPLIFICADA}

DO SITE
ENDERECO

\section{INFORMAÇÕES PERTINENTES À PESQUISA}

Conta com muitas informações, mas muitas desatualizadas e pouco detalhadas. Boas práticas, informação para elaboração de projetos para o Fundo Penitenciário, assim como os convênios e celebrados pelo Depen, através do Fundo. Alguns desses projetos serão apresentados em separado*.

Manual de Projetos de reintegração social. Guia do egresso. Material de PSC e Penas Alternativas.

Programa de reintegração de egressos, conta com uma equipe composta por profissionais das áreas de Direito, Psicologia e Serviço Social

Dentro de "Diretórios de grupos de pesquisa", pode-se encontrar alguns grupos no país que trabalham com a temática prisional

Descreve projeto "O Papel da Liberdade", desenvolvido pelo Departamento Penitenciário Nacional (Depen), que inclui a contratação de egressos trabalha no setor administrativo do próprio Ministério da Justiça.

Em 1993 uma série de ações (meditação, yoga, ventilação das queixas, manual do preso) foram adotadas com vista a transformar um dos maiores complexos prisionais do mundo. Site com informação dessas atividades hoje.

Programa de rádio e de televisão realizado dentro da Cadeia Feminina de Votorantim/SP, com transmissão em uma rádio local e em canais comunitários.

História e princípios da pastoral. Discussão de temas como voto do preso, mediação de conflitos. Uma série de textos sobre o sistema penitenciário. Relatórios do sistema prisional brasileiro. Pareceres.

ONG que realiza o projeto: “Quem somos nós?” 


\begin{tabular}{|c|c|c|}
\hline $24 / 10 / 2009$ & $\begin{array}{l}\text { Instituto Terra- Trabalho- } \\
\text { Cidadania - ITTC } \\
\text { http://www.ittc.org.br/web/ }\end{array}$ & $\begin{array}{l}\text { nas Penitenciárias Femininas da Capital e que } \\
\text { presta assistência jurídica às presas estrangeiras. } \\
\text { Muito interessante as publicações disponíveis } \\
\text { no site, tais como Manual do direito dos presos } \\
\text { e das presas e de Direitos Humanos. }\end{array}$ \\
\hline $24 / 10 / 2009$ & $\begin{array}{l}\text { Projeto Novos Rumos } \\
\text { na Execução Penal } \\
\text { http://www.premioinnovare.com.br }\end{array}$ & $\begin{array}{l}\text { O Prêmio Innovare identifica, premia e } \\
\text { dissemina práticas inovadoras realizadas por } \\
\text { magistrados, membros do Ministério Público } \\
\text { estadual e federal, defensores públicos e } \\
\text { advogados públicos e privados de todo Brasil, } \\
\text { que estejam aumentando a qualidade da } \\
\text { prestação jurisdicional e contribuindo com a } \\
\text { modernização da Justiça Brasileira. }\end{array}$ \\
\hline $24 / 10 / 2009$ & $\begin{array}{l}\text { Tribunal de Justiça- SP } \\
\text { http://www.tj.sp.gov.br/ }\end{array}$ & Nenhuma referência \\
\hline $25 / 10 / 2009$ & $\begin{array}{l}\text { Defensoria Pública - SP } \\
\text { http://www.defensoria.sp.gov.br/ }\end{array}$ & $\begin{array}{l}\text { Há no site a página do Núcleo de Situação } \\
\text { Carcerária, com diversos artigos, moções, } \\
\text { informações sobre rede de atendimento e rede } \\
\text { de presídios. O núcleo produziu em } 2008 \text { a } \\
\text { cartilha Enquanto a liberdade não chega!, que } \\
\text { explica os direitos e deveres das pessoas presas. }\end{array}$ \\
\hline $25 / 10 / 2009$ & $\begin{array}{l}\text { Ministério Público -SP } \\
\text { http://www.mp.sp.gov.br }\end{array}$ & Nenhuma referência \\
\hline 03/11/2009 & $\begin{array}{l}\text { Festipen- Festival de Música } \\
\text {-MG } \\
\underline{\text { http://www.festipen.com.br }}\end{array}$ & $\begin{array}{l}\text { O festival busca incentivar e divulgar novos } \\
\text { talentos musicais dentro das penitenciárias do } \\
\text { Estado de Minas Gerais, harmonizando e } \\
\text { criando assim uma melhor reintegração dos } \\
\text { detentos entre si e com a sociedade, Muito } \\
\text { interessante, mas fora do universo geográfico da } \\
\text { pesquisa. }\end{array}$ \\
\hline 03/11/2009 & $\begin{array}{l}\text { ILANUD } \\
\text { http://www.ilanud.org.br/ }\end{array}$ & $\begin{array}{l}\text { Diversas publicações. No núcleo de Justiça } \\
\text { Penal e Sistema Penitenciário, há descrição de } \\
\text { projetos em andamento (Grupo de Trabalho } \\
\text { sobre Educação nas Prisões) e de projetos } \\
\text { finalizados. }\end{array}$ \\
\hline 03/11/2009 & $\begin{array}{l}\text { NEV } \\
\text { http://www.nevusp.org/ }\end{array}$ & $\begin{array}{l}\text { Excelente banco de dados, uma série de } \\
\text { interessantes artigos. Além do tema as pesquisas } \\
\text { concluídas e em andamento }\end{array}$ \\
\hline $03 / 11 / 2009$ & $\begin{array}{l}\text { CTV } \\
\text { Comissão Teotônio Vilela } \\
\text { http://www.ctvdh.org/portal }\end{array}$ & $\begin{array}{l}\text { Tem relatórios por área temática, cobrindo as } \\
\text { atividades da Comissão ao longo dos anos. Em } \\
2001 \text {, a CTV elaborou um relatório sobre } \\
\text { prisões, que foi apresentado em audiência da } \\
\text { OEA. }\end{array}$ \\
\hline $04 / 11 / 2009$ & $\begin{array}{l}\text { GDUCC } \\
\text { Grupo de Diálogo } \\
\text { Universidade-Cárcere-Comunidade } \\
\text { http://getcrim.blogspot.com/ }\end{array}$ & $\begin{array}{l}\text { Grupo de extensão da Faculdade de Direito da } \\
\text { USP, que propõe uma vivência prática junto ao } \\
\text { sistema prisional, a partir de visitas realizadas } \\
\text { em unidade prisional, e vem construindo, no } \\
\text { decorrer dos anos, uma metodologia voltada a } \\
\text { restabelecer o diálogo que se rompeu antes } \\
\text { mesmo da prática do delito e que é } \\
\text { especialmente dificultado pelos muros do } \\
\text { cárcere. }\end{array}$ \\
\hline $18 / 01 / 2010$ & $\begin{array}{l}\text { IBCCRIM } \\
\text { http://www.ibccrim.org.br/ }\end{array}$ & $\begin{array}{l}\text { O instituo disponibiliza consulta virtual ao } \\
\text { ótimo acervo de sua biblioteca. Além da } \\
\text { promoção e divulgação de inúmeros eventos na } \\
\text { área de Ciências Criminais. Conta, ainda, com a } \\
\text { Comissão do Sistema Prisional, cujas reflexões } \\
\text { aparecem mais em forma de artigos do que no }\end{array}$ \\
\hline
\end{tabular}




\begin{tabular}{|c|c|c|}
\hline & & site. \\
\hline $18 / 01 / 2010$ & $\begin{array}{l}\text { CONSEG } \\
\text { www.conseg.gov.br/ }\end{array}$ & $\begin{array}{l}\text { Manual de Boas Práticas do Sistema } \\
\text { Penitenciário Nacional, o qual reúne ações } \\
\text { interessantes empreendidas em todos os Estados } \\
\text { da Federação, dentre as quais algumas de } \\
\text { reintegração social. }\end{array}$ \\
\hline $18 / 01 / 2010$ & $\begin{array}{l}\text { FUNAP } \\
\text { http://www.funap.sp.gov.br/ }\end{array}$ & $\begin{array}{l}\text { Descrição de alguns programas. Está disponível } \\
\text { o jornal Canto da liberdade. Divulgação de } \\
\text { eventos no sistema penitenciário. }\end{array}$ \\
\hline 19/01/2010 & $\begin{array}{l}\text { PROLER CARCERÁRIO } \\
\text { http://www.uesb.br/proler }\end{array}$ & $\begin{array}{l}\text { Projeto de incentivo a leitura e escrita na prisão- } \\
\text { Vitória da Conquista- BA da profa. Heleusa } \\
\text { Câmara. Muito interessante, mas fora do } \\
\text { universo geográfico da pesquisa. }\end{array}$ \\
\hline $19 / 01 / 2010$ & $\begin{array}{l}\text { AASP- Associação dos Advogados } \\
\text { de São Paulo } \\
\text { http://www.aasp.org.br }\end{array}$ & $\begin{array}{l}\text { Promoção do Curso Transdisciplinar de } \\
\text { Criminologia Penitenciária e Execução Penal, } \\
\text { com aulas teóricas e prática no cárcere, } \\
\text { realizado pelo Instituto de Ação Contra Cena } \\
\text { (IACC). }\end{array}$ \\
\hline $21 / 01 / 2010$ & $\begin{array}{l}\text { GITEP - } \\
\text { Grupo Interdisciplinar de Trabalho e } \\
\text { Estudos Criminais-Penitenciários - RS } \\
\text { http://antares.ucpel.tche.br/gitep/ }\end{array}$ & $\begin{array}{l}\text { Grupo inter e transdiciplinar, de Pelotas } \\
\text { (UCPEL).Através de reflexões e intervenções } \\
\text { de conteúdo científico-crítico, em torno do tripé } \\
\text { ensino-pesquisa-extensão, busca viabilizar uma } \\
\text { maior compreensão sobre as ciências criminais } \\
\text { e penitenciárias e as realidades que as cercam. }\end{array}$ \\
\hline $21 / 01 / 2010$ & $\begin{array}{l}\text { Ministério da Justica- } \\
\text { Convênio Depen- Alfasol/ } 2006 \\
\text { http://portal.mj.gov.br }\end{array}$ & $\begin{array}{l}\text { Concurso de Produção Literária para Internos e } \\
\text { Apenados do Sistema Penitenciário Nacional. }\end{array}$ \\
\hline $21 / 01 / 2010$ & $\begin{array}{l}\text { Prêmio Policia Cidadã Rio } \\
\text { http://www.premiopoliciario.com.br/ }\end{array}$ & $\begin{array}{l}\text { Dentre os premiados está o programa } \\
\text { Carceragem Cidadã do Delegado Orlando } \\
\text { Zaccone, que criou o "Cine Clube 52", em que } \\
\text { documentários, filmes e curtas-metragens são } \\
\text { exibidos, seguidos de palestras e shows ao vivo, } \\
\text { para cerca de } 300 \text { detentos. Além de uma } \\
\text { biblioteca- onde é editado um jornal feito pelos } \\
\text { presos "O Sol Quadrado Também Brilha" }\end{array}$ \\
\hline $22 / 01 / 2010$ & $\begin{array}{l}\text { Ação Educativa } \\
\text { http://www.acaoeducativa.org/ }\end{array}$ & $\begin{array}{l}\text { Site com muitas informações da aérea da } \\
\text { educação. Interessa-nos, em especial, a pesquisa } \\
\text { Direito Humano à Educação no Sistema } \\
\text { Prisional Brasileiro. }\end{array}$ \\
\hline $22 / 01 / 2010$ & $\begin{array}{l}\text { Nadir- USP } \\
\text { Núcleo de Antropologia do Direito } \\
\text { http://www.fflch.usp.br/ }\end{array}$ & $\begin{array}{l}\text { O grupo reúne pesquisadores e estudantes de } \\
\text { graduação, mestrado e doutorado, tanto da USP } \\
\text { quanto de outras instituições, interessados em se } \\
\text { aprofundar nas múltiplas interfaces existentes e } \\
\text { possíveis entre antropologia e direito. }\end{array}$ \\
\hline 28/01/2010 & $\begin{array}{l}\text { Festival Teatre Prision } \\
\text { http://www.ateneu9b.net/arxius/ }\end{array}$ & $\begin{array}{l}\text { Festival de criações artísticas na prisão, e se } \\
\text { insere dentro de um programa de eventos } \\
\text { culturais dessa produção. Diversos grupos } \\
\text { europeus - que formaram Teatrodentro, criaram } \\
\text { uma "Asociación de Aprendizaje -intercambios } \\
\text { de metodologias". }\end{array}$ \\
\hline 28/01/2010 & $\begin{array}{l}\text { TRANS- FORMA Teatrodentro } \\
\text { http://www.transformas.com }\end{array}$ & $\begin{array}{l}\text { Projetos de grupos teatrais e fotográficos em } \\
\text { prisões em Barcelona. Cursos de Teatro do } \\
\text { oprimido (Augusto Boal). }\end{array}$ \\
\hline & & Estásticas trimestrais que "monitorar a evolução \\
\hline
\end{tabular}




\begin{tabular}{|c|c|c|}
\hline $28 / 01 / 2010$ & $\begin{array}{l}\text { Secretaria de Segurança Pública SP } \\
\text { http://www.ssp.sp.gov.br/ }\end{array}$ & $\begin{array}{l}\text { e as tendências criminais em todo o Estado de } \\
\text { São Paulo" }\end{array}$ \\
\hline $28 / 01 / 2010$ & $\begin{array}{l}\text { Secretaria da Justiça SP } \\
\text { http://www.justica.sp.gov.br/ }\end{array}$ & $\begin{array}{l}\text { No campo Programas e projetos, há a descrição } \\
\text { de diversas de programas da Secretaria, tais } \\
\text { como CIC - Centro de Integração da Cidadania; } \\
\text { Cravi - Centro de Referência e Apoio à Vítima, } \\
\text { Câmara de Mediação; Núcleo de Enfrentamento } \\
\text { ao Tráfico de Pessoas . }\end{array}$ \\
\hline $28 / 01 / 2010$ & $\begin{array}{l}\text { Blog do Professor Celso Rodrigues, } \\
\text { coordenador do Projeto Direitos Humanos } \\
\text { na } \\
\text { http://profcelsorodrigues.blogspot.com/ }\end{array}$ & $\begin{array}{l}\text { Projeto de extensão da Fadipa (Faculdade de } \\
\text { Direito de Ipatinga- MG), que recebeu o prêmio } \\
\text { Educação } 2009 \text { do SINPRO. }\end{array}$ \\
\hline $1 / 02 / 2010$ & $\begin{array}{l}\text { Projeto Leiturativa } \\
\text { http://www.fespsp.org.br/leiturativa.htm }\end{array}$ & $\begin{array}{l}\text { Projeto de extensão da FESP-SP(Fundação } \\
\text { Escola de Sociologia e Política) que tem por } \\
\text { objetivo o incentivo à leitura mediante ações } \\
\text { culturais e a oferta de meios de informação. A } \\
\text { partir de } 2010 \text {, o projeto será ampliado para } 26 \\
\text { estabelecimentos no Estado de São Paulo. }\end{array}$ \\
\hline $1 / 02 / 2010$ & $\begin{array}{l}\text { Instituto de Criminologia e Alteridade } \\
\text { http://criminologiaealteridade.ning.com/ }\end{array}$ & $\begin{array}{l}\text { Rede social (ning) com espaço de troca } \\
\text { transdisciplinar entre seus membros para pensar } \\
\text { e deslegitimar as razões da violência, além de } \\
\text { reflexões acerca da violência, sistema de justiça, } \\
\text { arte, etc. }\end{array}$ \\
\hline $02 / 02 / 2010$ & $\begin{array}{l}\text { Tribunal de Justiça- MG } \\
\text { http://www.tjmg.jus.br/ }\end{array}$ & $\begin{array}{l}\text { Notícias sobre a criação de Centros de } \\
\text { Reintegração Social, gerenciados pelas Apacs } \\
\text { (Associação de proteção e assistência aos } \\
\text { condenados) de Minas Gerais) }\end{array}$ \\
\hline $02 / 02 / 2010$ & $\begin{array}{l}\text { Lista das Apacs do Brasil } \\
\text { http://www.giovaniemissione.it/gim/docu } \\
\underline{\text { menti/indirizzi\%20apac.pdf }}\end{array}$ & $\begin{array}{l}\text { Relação das Apacs do Brasil, com endereço- } \\
\text { telefone para contato. }\end{array}$ \\
\hline $02 / 02 / 2010$ & $\begin{array}{l}\text { Conselho Nacional de Justiça } \\
\text { http://www.cnj.jus.br/ }\end{array}$ & $\begin{array}{l}\text { O site conta com um material bastante } \\
\text { interessante. A começar a apresentação do } \\
\text { Projeto Começar de Novo e diversas de suas } \\
\text { campanhas em vídeo. Dados do Sistema } \\
\text { Carcerário Nacional, Manual Prático De Rotinas } \\
\text { das Varas Criminais e de Execução Penal, } \\
\text { "Cartilha do reeducando", Advocacia } \\
\text { Voluntária, Mutirões, etc. }\end{array}$ \\
\hline
\end{tabular}

* Detalhamento dos projetos encontrados no site do DEPEN ${ }^{335}$

\section{ANEXO 2 \\ CONVÊNIOS FIRMADOS PELO DEPEN ENTRE 2004-2006}

\begin{tabular}{ccc} 
PROJETO & CONVENENTE & UF/ANO \\
\hline Curso de Especialização em Gestão Prisional & Universidade do Estado da Bahia & BA/2004 \\
\hline
\end{tabular}

335 http://www.mj.gov.br/data/Pages/MJDA8C1EA2ITEMIDB6397CD625A644849D8D9D50 156D22A2PTBRNN.htm, acesso 13/10/09. 


\begin{tabular}{|c|c|c|}
\hline Curso de Pós Graduação Latu Sensu & $\begin{array}{l}\text { Fundação da Universidade Federal do } \\
\text { Paraná }\end{array}$ & $\mathrm{PR} / 2004$ \\
\hline $\begin{array}{l}\text { Implantação de Unidades de Panificação em } \\
\text { Estabelecimentos Penais de Mato Grosso do } \\
\text { Sul }\end{array}$ & $\begin{array}{l}\text { Secretaria de Estado de Justiça e } \\
\text { Segurança Pública }\end{array}$ & MS/2005 \\
\hline Projeto Arca das Letras II & Secretaria de Defesa Social & $\mathrm{PE} / 2005$ \\
\hline Projeto Político Pedagógico & $\begin{array}{l}\text { Secretaria de Estado da Justiça e da } \\
\text { Cidadania do } \\
\text { Maranhão }\end{array}$ & MA/2005 \\
\hline Implementação da Escola Penitenciária & Secretaria de Estado de Justiça & $\mathrm{ES} / 2005$ \\
\hline Implantação da Escola Penitenciária & $\begin{array}{l}\text { Secretaria de Estado de Justiça e } \\
\text { Segurança Pública }\end{array}$ & $\mathrm{MS} / 2005$ \\
\hline $\begin{array}{l}\text { Projeto Político Pedagógico e Implementação } \\
\text { da Escola de Administração Penitenciária ( } \\
\text { convênios) }\end{array}$ & $\begin{array}{lll}\text { Secretaria } & \text { de } & \text { Administração } \\
\text { Penitenciária } & & \end{array}$ & $\mathrm{PB} / 2005$ \\
\hline Curso Grupo de Apoio às Ações Penitenciárias & $\begin{array}{l}\text { Secretaria de Estado da Justiça e da } \\
\text { Cidadania }\end{array}$ & $\mathrm{PR} / 2005$ \\
\hline $\begin{array}{l}\text { Implantação de Escola de } \\
\text { Qualificação e Cormação, } \\
\text { Penitenciários }\end{array}$ & $\begin{array}{l}\text { Secretaria de Estado de Administração } \\
\text { Penitenciária }\end{array}$ & $\mathrm{RO} / 2005$ \\
\hline $\begin{array}{l}\text { Capacitação para os operadores do } \\
\text { Sistema Penitenciário }\end{array}$ & $\begin{array}{l}\text { Secretaria de Estado de Administração } \\
\text { Penitenciária }\end{array}$ & $\mathrm{RO} / 2005$ \\
\hline $\begin{array}{l}\text { Implantação da Escola de Administração } \\
\text { Penitenciária }\end{array}$ & $\begin{array}{l}\text { Secretaria de Estado da Justiça e da } \\
\text { Cidadania de Sergipe }\end{array}$ & $\mathrm{SE} / 2005$ \\
\hline Arca das Letras & Secretaria da Justiça e Cidadania & $\mathrm{CE} / 2006$ \\
\hline Mãos que Florescem & Secretaria Executiva de Ressocialização & $\mathrm{AL} / 2006$ \\
\hline $\begin{array}{l}\text { Aquisição de Equipamentos de Saúde para } 09 \\
\text { Unidades Prisionais }\end{array}$ & Secretaria de Defesa Social & MG/2006 \\
\hline Projeto Libertas - do Outro Lado do Muro & $\begin{array}{l}\text { Secretaria de Estado da Justiça do } \\
\text { Maranhão }\end{array}$ & MA/2006 \\
\hline Projeto Nascer da Terra & $\begin{array}{l}\text { Secretaria de Estado da Justiça e da } \\
\text { Cidadania }\end{array}$ & $\mathrm{RN} / 2006$ \\
\hline $\begin{array}{l}\text { Projeto Criação do Centro de Excelência do } \\
\text { Sistema de Execução Penal }\end{array}$ & Secretaria de Estado da Justiça do Goiás & $\mathrm{GO} / 2006$ \\
\hline $\begin{array}{l}\text { Projeto Político Pedagógico para a Escola } \\
\text { Penitenciária }\end{array}$ & Secretaria Executiva de Ressocialização & AL/2006 \\
\hline Projeto Arca das Letras & $\begin{array}{l}\text { Secretaria de Estado da Justiça e da } \\
\text { Cidadania }\end{array}$ & $\mathrm{RN} / 2006$ \\
\hline $\begin{array}{l}\text { Programa de Qualificação Profissional no } \\
\text { âmbito da Justiça e Cidadania do Estado }\end{array}$ & $\begin{array}{l}\text { Secretaria de Estado da Justiça e da } \\
\text { Cidadania }\end{array}$ & $\mathrm{SE} / 2006$ \\
\hline Em Defesa dos Direitos dos Presos & $\begin{array}{l}\text { Defensoria Pública do Estado de São } \\
\text { Paulo }\end{array}$ & $\mathrm{SP} / 2006$ \\
\hline Projeto Unidade de Saúde & $\begin{array}{l}\text { Secretaria de Estado da Administração } \\
\text { Penitenciária }\end{array}$ & $\mathrm{RO} / 2006$ \\
\hline Novos Horizontes & $\begin{array}{l}\text { Centro de Integração Empresa Escola - } \\
\text { CIEE/SC }\end{array}$ & $\mathrm{SC} / 2006$ \\
\hline $\begin{array}{l}\text { Curso de Formação Específica em Gestão do } \\
\text { Sistema Prisional }\end{array}$ & Fundação Universitária do Cerrado & $\mathrm{GO} / 2006$ \\
\hline $\begin{array}{l}\text { Brinquedoteca } \quad-\quad \text { Brincar } \\
\text { Ressocializar }\end{array}$ & $\begin{array}{l}\text { Secretaria de Estado da Justiça e Direitos } \\
\text { Humanos }\end{array}$ & $\mathrm{AM} / 2006$ \\
\hline $\begin{array}{l}\text { Projeto "implantação de Fábricas de Artefatos } \\
\text { de Concreto Pré-moldados nas Unidades } \\
\text { Prisionais }\end{array}$ & $\begin{array}{l}\text { Secretaria de Estado de Justiça e } \\
\text { Segurança Pública }\end{array}$ & MT/2006 \\
\hline Maria Marias & Secretaria de Estado da Justiça & ES/2006 \\
\hline Qualificação Profissional do Reeducando & $\begin{array}{l}\text { Secretaria da Justiça e Cidadania do } \\
\text { Estado de Goiás }\end{array}$ & $\mathrm{GO} / 2006$ \\
\hline Plantando Mudas para Mudar Vidas & $\begin{array}{l}\text { Secretaria de Estado de Administração } \\
\text { Penitenciária }\end{array}$ & $\mathrm{RO} / 2006$ \\
\hline Capacitação de Agentes de Escolta & Secretaria de Estado de Justiça e & MT/2006 \\
\hline
\end{tabular}




\begin{tabular}{|c|c|c|}
\hline & Segurança Pública & \\
\hline Projeto Treinamento Básico para Docentes & $\begin{array}{l}\text { Secretaria de Estado de Justiça e } \\
\text { Segurança Pública }\end{array}$ & $\mathrm{MT} / 2006$ \\
\hline Implantação da Escola Penitenciária & $\begin{array}{l}\text { Secretaria de Estado de justiça e Direitos } \\
\text { Humanos }\end{array}$ & $\mathrm{AM} / 2006$ \\
\hline Projeto Educação Profissional & $\begin{array}{l}\text { Serviço Nacional de Aprendizagem } \\
\text { Comercial }\end{array}$ & MA/2006 \\
\hline Projeto Arca das Letras & $\begin{array}{l}\text { Secretaria de Estado de Administração } \\
\text { Penitenciária }\end{array}$ & $\mathrm{RO} / 2006$ \\
\hline $\begin{array}{l}\text { Fábrica de Saneantes para o Sistema Prisional } \\
\text { do Estado }\end{array}$ & $\begin{array}{l}\text { Secretaria de Estado de Justiça e } \\
\text { Segurança Pública }\end{array}$ & MT/2006 \\
\hline Projeto Brinquedoteca - Desafios e Descobertas & $\begin{array}{l}\text { Secretaria de Estado da Justiça e } \\
\text { Segurança }\end{array}$ & $\mathrm{AP} / 2006$ \\
\hline Projeto Arca das Letras & Secretaria da Justiça e da Cidadania & MA/2006 \\
\hline Reaparelhamento da Escola Penitenciária & $\begin{array}{l}\text { Secretaria de Estado de Justiça e } \\
\text { Segurança }\end{array}$ & $\mathrm{RS} / 2006$ \\
\hline Projeto Mente Livre: Yoga nas Prisões & Secretaria da Justiça e da Cidadania & $\mathrm{RN} / 2006$ \\
\hline Implantação da Escola Penitenciária & Secretaria da Justiça e da Cidadania & $\mathrm{RN} / 2006$ \\
\hline Implantação da Escola Penitenciária & Secretaria de Defesa Social & $\mathrm{PE} / 2006$ \\
\hline $\begin{array}{l}\text { Projeto Edhucar: Educação em } \\
\text { Humanos e Serviços Penais na } \\
\text { Penitenciária }\end{array}$ & $\begin{array}{l}\text { Secretaria da Justiça e de Direitos } \\
\text { Humanos }\end{array}$ & $\mathrm{PI} / 2006$ \\
\hline Projeto Reconstruindo a Dignidade & $\begin{array}{l}\text { Secretaria de Estado de Administração } \\
\text { Penitenciária }\end{array}$ & $\mathrm{RO} / 2006$ \\
\hline Projeto KK - trabalho e Cidadania (presos) & Universidade Federal Fluminense & $\mathrm{RJ} / 2006$ \\
\hline Projeto Nascer da Terra & Secretaria Executiva de Ressocialização & $\mathrm{AL} / 2006$ \\
\hline Projeto de Implantação da Escola Penitenciária & Secretaria da Justiça e Cidadania & $\mathrm{CE} / 2006$ \\
\hline $\begin{array}{l}\text { Formação de Agentes Penitenciários em } \\
\text { Educação a Distância }\end{array}$ & $\begin{array}{l}\text { Serviço Nacional de Aprendizagem } \\
\text { Industrial }\end{array}$ & $\mathrm{DF} / 2006$ \\
\hline $\begin{array}{l}\text { Plano Nacional de Saúde do Sistema } \\
\text { Penitenciário }\end{array}$ & $\begin{array}{l}\text { Secretaria } \\
\text { Penitenciária }\end{array}$ de $\quad$ Administração & $\mathrm{SP} / 2006$ \\
\hline $\begin{array}{l}\text { Concurso de Produção Literária para Internos e } \\
\text { Apenados do Sistema Penitenciário Nacional }\end{array}$ & Associação de Alfabetização Solidária & $\mathrm{SP} / 2006$ \\
\hline
\end{tabular}

